DOE/NASA CONTRACTOR REPORT

DOE/NASA CR-150553

\title{
SOLAR HEATING SYSTEM FOR RECREATION BUILDING AT SCATTERGOOD SCHOOL
}

Prepared by

Scattergood School

West Branch, Iowa 52358

Under Contract DOE No. EX-76-C-01-2386

Monitored by

National Aeronautics and Space Administration

George C. Marshall Space Flight Center, Alabama 35812

for the U. S. Department of Energy

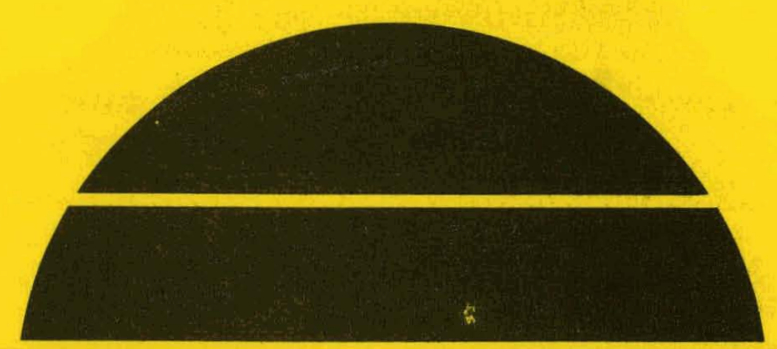

\section{U.S. Department of Energy}




\section{DISCLAIMER}

This report was prepared as an account of work sponsored by an agency of the United States Government. Neither the United States Government nor any agency Thereof, nor any of their employees, makes any warranty, express or implied, or assumes any legal liability or responsibility for the accuracy, completeness, or usefulness of any information, apparatus, product, or process disclosed, or represents that its use would not infringe privately owned rights. Reference herein to any specific commercial product, process, or service by trade name, trademark, manufacturer, or otherwise does not necessarily constitute or imply its endorsement, recommendation, or favoring by the United States Government or any agency thereof. The views and opinions of authors expressed herein do not necessarily state or reflect those of the United States Government or any agency thereof. 


\section{DISCLAIMER}

Portions of this document may be illegible in electronic image products. Images are produced from the best available original document. 
NOTICE

This report was prepared to document work sponsored by the United States Government. Ne1ther the Unfted States nor 1 ts agents the Unfted States Department of Energy, the United States National Aeronautics and Space Administration, nor any federal employees, nor any of their contractors, subcontractors or thelr employees, make any warranty, express or 1mplied, or assume any legal 11ab1lity or responsibility for the accuracy, completeness, or usefulness of any informat1on, apparatus, product or process disclosed, or represent that 1ts use would not infringe privately owned rights. 


\begin{tabular}{|c|c|}
\hline $\begin{array}{l}\text { 1. REPORT NO. } \\
\text { DOE/ NASA CR-150553 }\end{array}$ & 3. RECIPIENT'S CATALOG NO. \\
\hline \multirow{2}{*}{$\begin{array}{l}\text { 4. TITLE AND SUBTITLE } \\
\text { Solar Heating System for Recreation Building at } \\
\text { Scattergood School }\end{array}$} & $\begin{array}{l}\text { 5. REPORT DATE } \\
\text { 3 January } 1978\end{array}$ \\
\hline & 5. PERFORMING ORGANIZATION COIDE \\
\hline $\begin{array}{l}\text { 7. AUTHOR(S) } \\
\text { Dr. Conrad F. Heins }\end{array}$ & 8. PERFORMING ORGANIZATION REPOR T \\
\hline \multirow{3}{*}{$\begin{array}{l}\text { 9. PERFORMING ORGANIZATION NAME AND ADDRESS } \\
\text { Scattergood School } \\
\text { West Branch,Iowa } 52358\end{array}$} & 10. WORK UNIT NO. \\
\hline & $\begin{array}{l}\text { 11. CONTRACT OR GRANT NO. } \\
\text { DOE NO. EX }-76-C-01-2386\end{array}$ \\
\hline & 13. TYPE OF REPOR'i \& PERIOD COVERED \\
\hline \multirow{2}{*}{$\begin{array}{l}\text { 12. SPONSORING AGENCY NAME AND ADORESS } \\
\text { National Aeronautics and Space Administration } \\
\text { Washington, D. C. } 20546 \\
\text { for the Department of Energy. }\end{array}$} & $\begin{array}{l}\text { Contractor Report } \\
\text { Final }\end{array}$ \\
\hline & 1.4. SPONSORING AGENCY CODE \\
\hline
\end{tabular}

15. SUPPLEMENTARY NOTES

The Project Manager for this work was Dr. Conrad F. Heins, of the Scattergood School. The work was accomplished under the technical management of Hoyt M. Weathers, Marshall Space Filight Center, Alabama.

16. ABSIIRACT

This project was initiated in May 1976 and was completed in June 1977. A six-month acceptance-testing period followed during which time a number of minor modifications and corrections were made to improve system performance and versatility. This Final Report describes in considerable detail the solar heating facility and the project involved in its construction. As such, it has both detailed drawings of the completed system and a section. that discusses the bottlenecks that were encountered along the way. It is hoped that the report will prove useful to others who choose to use the sun's energy to provide at least part of their heating needs.

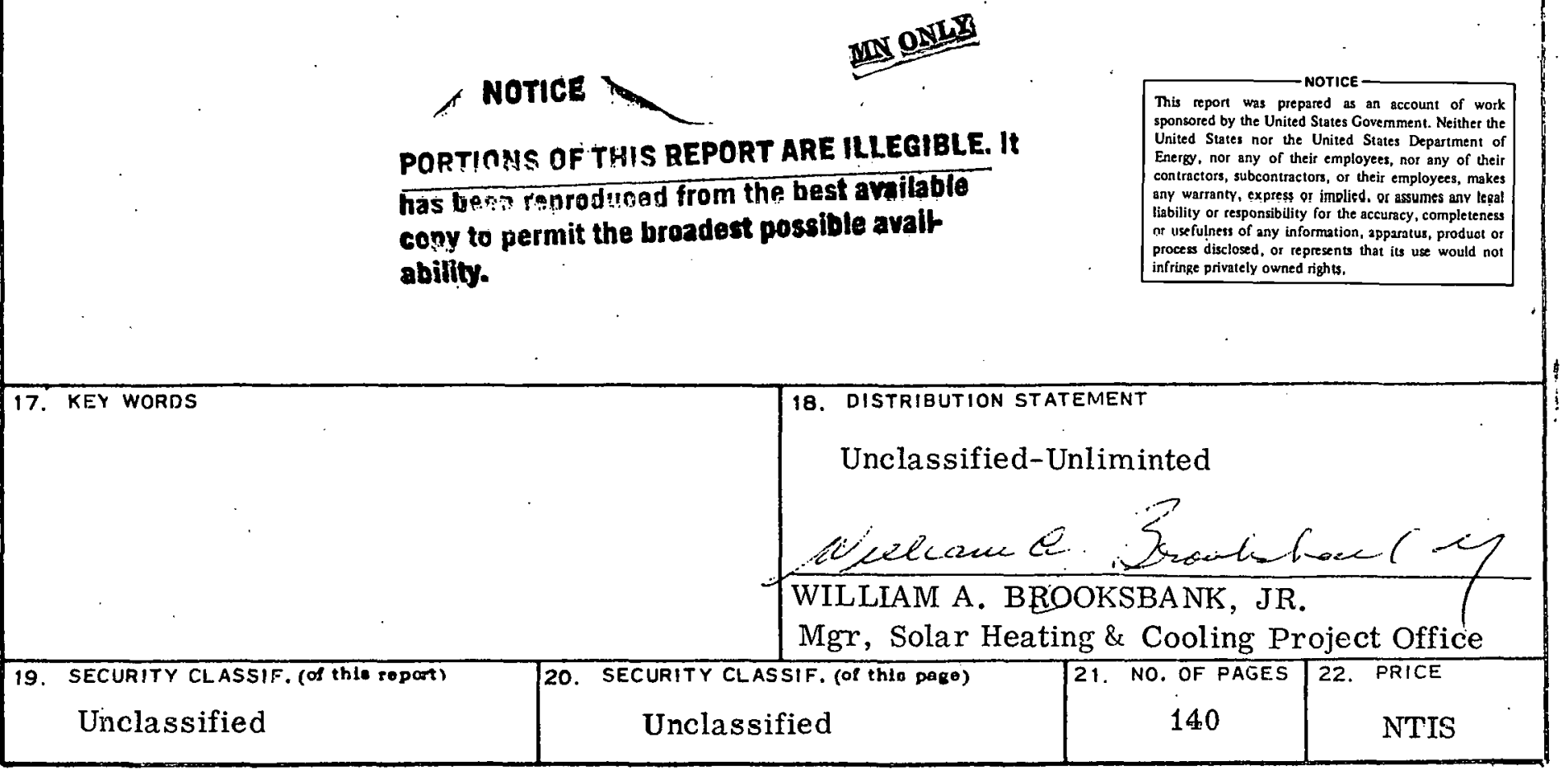


THIS PAGE

\section{WAS INTENTIONALLY LEFT BLANK}




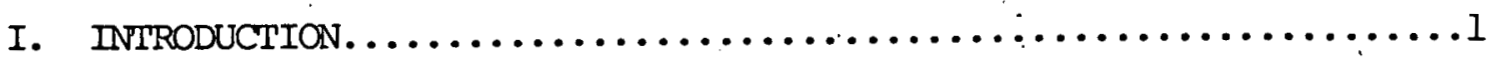

II. SUMMARY OF PROJECT IINFORMATION. $\ldots \ldots \ldots \ldots \ldots \ldots \ldots \ldots \ldots \ldots \ldots \ldots \ldots$

III. DESCRIPTION OF THE SOLAR HEATED RECREATION BUILDING. .........5

IV. DESCRIPTION OF THE SOLAR HEATING SYSTEM. ...............

A. COMPONENT SUBSYSTEMS. . . . . . . . . . . . . . . . . . .

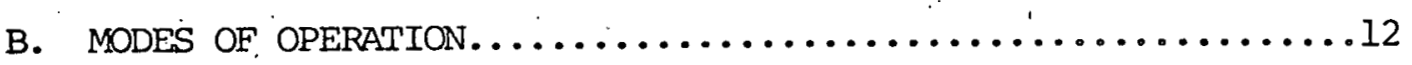

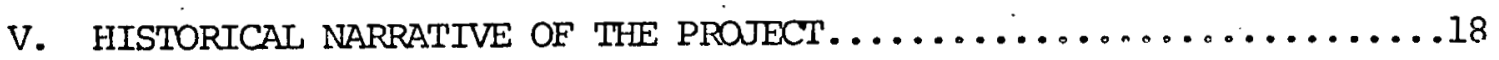

VI. DESCRIPITION OF. THE DATA ACQUISITION SYSTEM. .............. 27

VII. COSTS OF THE SCATTERGOOD SCHOOL SOLAR IEATING SYSTEM. . . . . . . 30

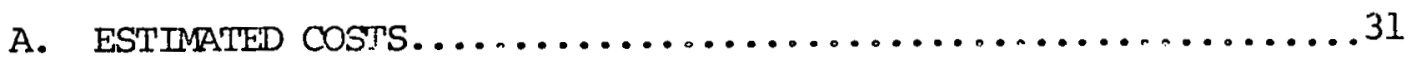

B. ACTUAL COSTS ................................. 31

VIII. WHAT WE WOULD DO DIFEERENTLY IF WE WNER TO DO IT AGATN.......32

IX. INTERTM PERFORMANCE CRITERIA CERTIFYCATION. ................. 33 APPENDIX A - BUILDING DRAWINGS

APPENDIX B - DESIGN AND SCHEMATIC DRAWINGS OR THE SOLAR HEATING SYSTEM APPENDIX C -- AS BUIIT DRAWINGS OF THE SOLZIR HITATING SYSTEM

APPENDIX D - WIRTNG DIAGRAMS OF THE SOLAR HEATING SYSTEM

APPENDIX E -- SEQUENCE OF OPERATIONS OF THE SOLAR HEATTNG SYSTEM

APPENDIX F -- MATNTENANCE INSTRUCTIONS FOR THE SOLAR HIATIIJG SYSTEM

APPENDIX G - SUBCONTRACTORS ASSOCIATED WITH THE SOLAR HEATING PROJECT

IPPENDIX $\mathrm{H}$-- ACCEPTANCE TEST OF THE SOLAR HEATING SYSTEM

APPENDIX I -- REPORT ON GRAIN DRYING MODIFICATION TO SCATIERGOOD SCHOCL SOIAR HEATING SYSTEM

APPENDIX J -- PRODUCT LITERATURE FOR COMPONENTS OF. THE SOLAR IEATING SYSTEM 


\section{INTRODUCTION}

Scattergood School is a small, co-educational boarding school located in the farmland of eastern Iowa 10 miles east of Iowa City. In the fall of 1974, the governing committee of the school decided to build a badly needed recreation building that would utilize, in some fashion, solar energy to provide at least part of the heating requirements of the building. With the announcement that the federal Energy Research and Development Administration (ERDA) would be funding solar projects as part of the Solar Heating and Cooling Demonstration Program, the school began to consider systems that would suit their needs and might qualify for federal assistance as well.

It was decided, to use an air, rather than a water, system. Since most of the solar energy would be used to heat the air of the building, it made sense to heat this air directly. In addition, the simplicity of an air system, with very few moving parts and no catastrophic modes of failure, was attractive. The Solaron Corporation of Denver, Colorado, a company with considerable experience in air collector systems, was invited to join with the school in preparing a proposal. Solaron complied, and in November, 1975, a proposal was submitted to, and subsequently accepted by, ERDA.

The proposal suggested the use of a 2500 square foot array of Solaron collectors, a heat storage box containing 1250 cubic feet of rock, and a $5000 \mathrm{cfm}$ air handling unit. Such a system would provide an estimated 75\% of the building's heating needs. In addition, an air-water heat 
exchanger would serve to preheat water for a domestic hot water system.

The project was initiated in May, 1976, and was completed in June, 1977. A b-month acceptance testing period followed during which time a number of minor modifications and corrections were made to improve system performance and versatility. This Final Report describes in considerable detail the solar heating facility and the project involved in its construction. As such, it has both detailed drawings of the completed system and a section that discusses the bottlenecks that were encountered along the way. It is hoped that the report will prove useful to others who choose to use the sun's energy to provide at least part of their heating needs.

Scattergood School is grateful to the Solar Energy Division of the Department of Energy for providing most of the funds for the solar heating system. The school would also like to acknowledge the generous technical assistance of the personnel from the National Aeronautics and Space Administration, George C. Marshall Space Flight Center, throughout the course of the project. 
II. SUMMARY OF. PROTECT INFORAMTION

A. General Information

Owner/Builder: Scattergood School

West Branch, Iowa 52358

Contractor: Modern Metals, Inc. Muscatine, Iowa 52761

Operational Date: June, 1977

Building:

Type: School gymmasium

Area: 7966 sq. ft.

Location: West Branch, Iowa

B. Meteorological Data

Latitude: $41.8^{\circ} \mathrm{N}$

Climate Data:

winter

Summer

Avg. temp. $\left({ }^{\circ} \mathrm{F}\right)$

41.0

71.7

Avg. insolation (Ly/d)

298

545

Degree days (heating): 7255

‥ Solar Energy System

Application: Heating, 75\%; hot water, 75\%

Collector:

Type: Air heating, flat plate

Area: 2496 sq. ft.

Manufacturer: Solaron Corporation

Denver, Colorado 80222 


\section{Storage;}

Type; 3/4-ingh diameter Fack

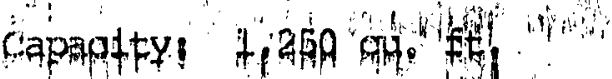

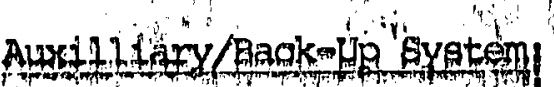

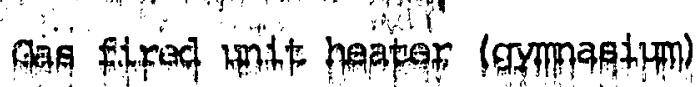

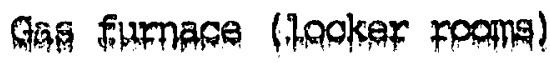

Electric heater (water)

\section{Project Description}

The solar energy system is based on a prototype model which has been in continuous successful operation since 1957. The collector array, attached to the south side of the building, consists of 128 factoryassembled modules 36 in. by 78 in. Each module has double tempered glass covers and a sheet absorber, with an air duct below the permanent black absorber surface. The metal building is preengineercd (Irmoo Metal Building Systems) with 6900 sq. ft. in the gymasium portion and $1066 \mathrm{sq}$. ft. in the locker room/storage section. The anticipated structural heating load 1s 56,000 BTU prer degree day. 
III. DESCRIPTION OF THE SOLAR HEATED RECREATION BUIIDING

The facility consists of two adjoining Armco Rigidframe buildings designed and fabricated by the Armco Steel Corporation, Metal Products Division. The gymmasium building has floor dimensions of 70 feet by 98 feet 8 inches, is 24 feet at the eave and about 29 feet at the peak. The locker room building has floor dimensions of 25 feet by 42 feet 8 inches and has an eave height of 12 feet 3 inches. The locker room building is attached to the east side of the main building. Both structures are well-insulated with fiberglass insulation. The solar heating system will provide an estimated $75 \%$ of the building's total heating needs, including hot water. Auxiliary heat is provided by two $250 \mathrm{KBTU}$ propane unit heaters in the main building. A dual 5.5 kilowatt, fast-recovery, electric water heater provides domestic hot water. Intake water is preheated by the solar heating system and stored in two insulated 120-gallon, glass-lined tanks.

Blue prints showing floor plans and building details can be found in Appendix A. A photograph of the recreation building, depicting the solar panels, is shown on the next page. 


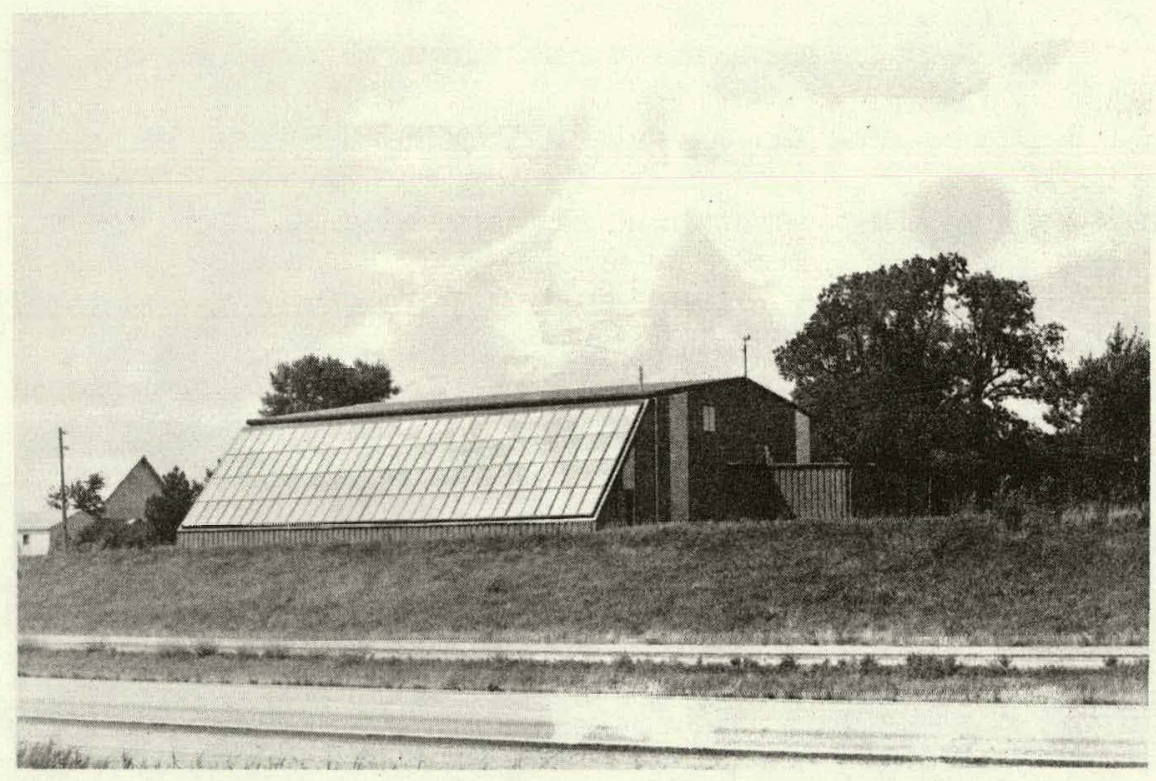

1. The Scattergood School solar heated recreation building. 
IV. DESCRIPTION OF THE SOLAR HEATING SYSTEM

A. Component Subsystems

Scattergood School's solar heating system consists of seven parts.

1. A solar collector.

A 2500 square foot array of flat platecollectors purchased from the Solaron Corporation uses sunlight to heat air drawn through the system.

2. A heat storage device.

An insulated reinforced-concrete box (10 feet by 25 feet by 7 feet) filled with 65 tons of smooth river gravel stores heat during sunny days to be used at night or on cloudy days.

3. An air handling system.

A large blower moves air through the collectors and into ductwork that enters the building and/or the rock box.

4. A water heater.

An air-water heat exchanger built into the ductwork preheats water for a domestic, fast-recovery electric water heater. Water is stored in two 120-gallon tanks connected in series. It is pumped through the heat exchanger whenever the panel system is collecting solar energy and the water temperature is below a predetermined temperature.

5. An automatic control system.

Thermostats and other temperature sensing devices autumalically regulate the water pump, the air blower and the motorized dampers used to operate the system. 
6. An auxiliary heating system.

Two $250 \mathrm{KBTU}$ space heaters in the main building and a $100 \mathrm{KBTU}$ furmace in the locker room building provide supplemental heat as needed. A 5.5 kilowatt, fast-recovery electric water heater provides domestic hot water. The solar system preheats water for this unit.

7. A data acquisition system. Thirty-one sensors located throughout the installation provide data on parameters such as air flow, air temperature, water temperature and sunlight striking the colector. These data are automatically stored on tape and sent daily to a data processing center in Huntsville, Alabama. This monitoring subsystem will provide answers to such key questions as system efficiency and reliability, operating costs and approximate fuel savings. Photographs of these various components are shown on the next three pages. 


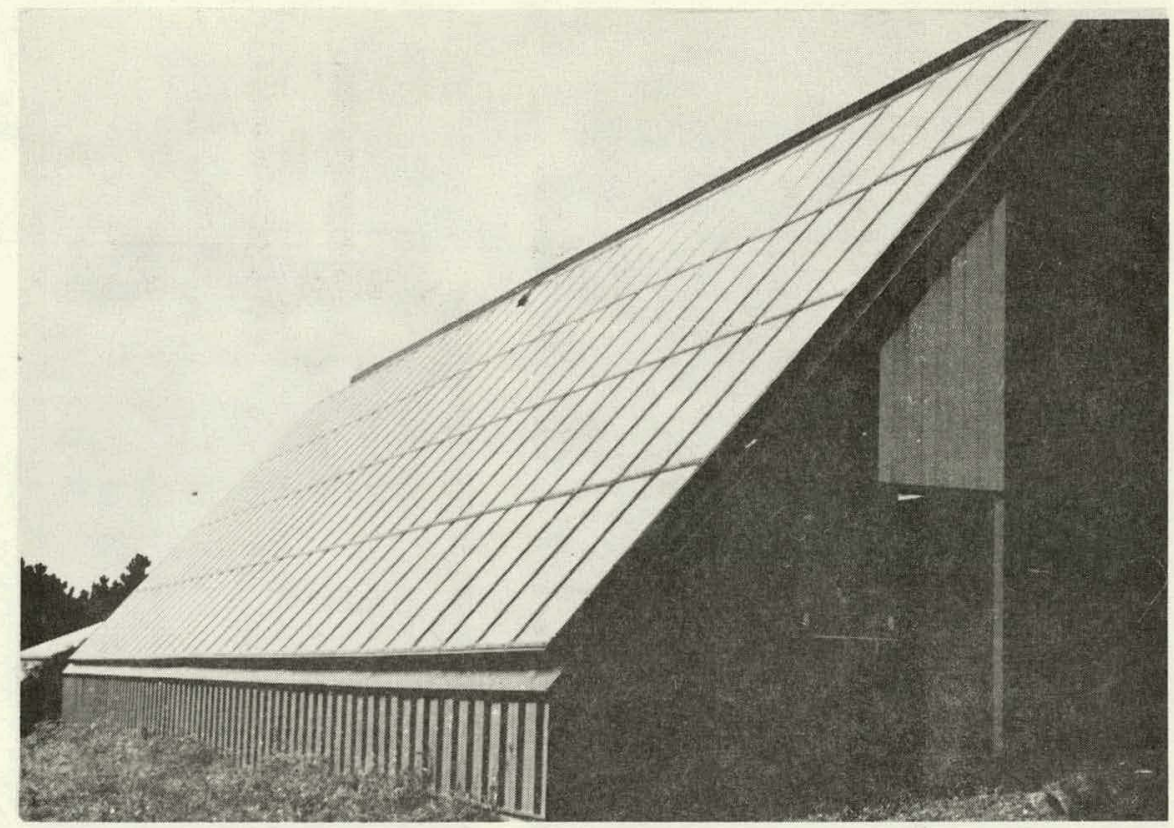

2. The collector,

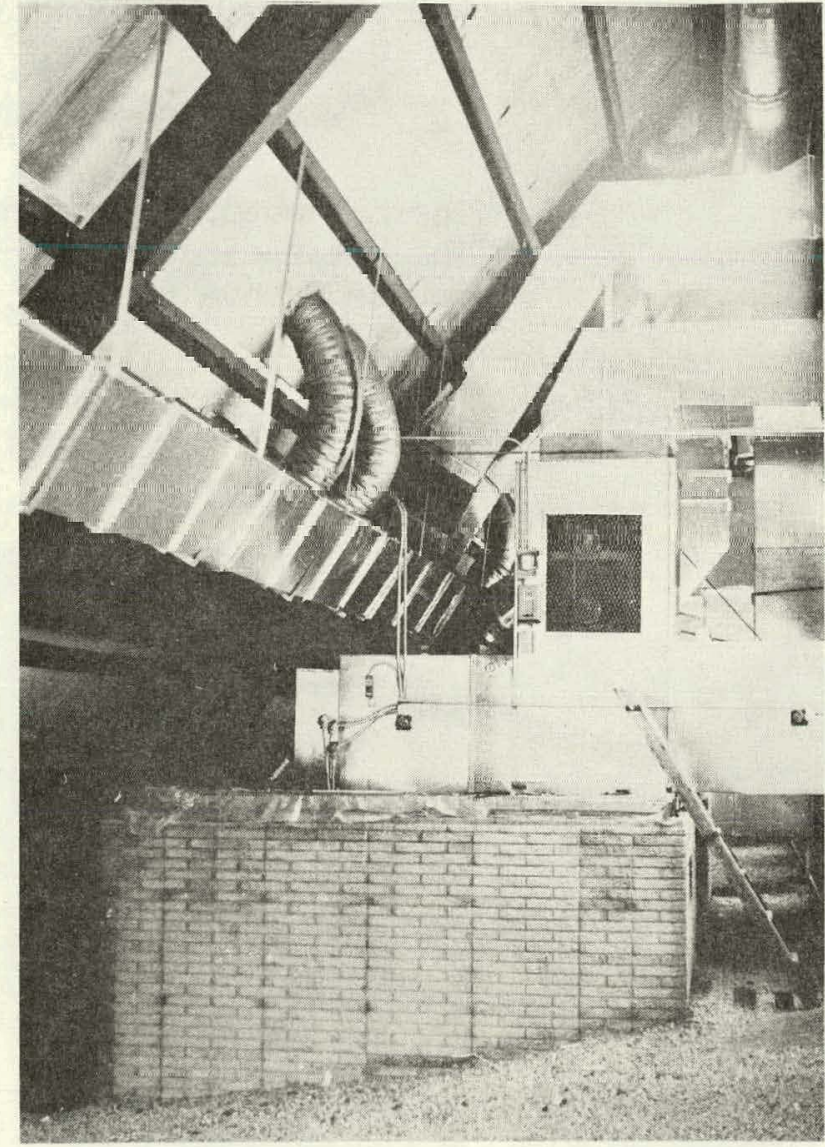

3. The rock storage box. The air handling unit, with associated ductwork, is above it. The collector panels are outside, mounted on the plywood deck.

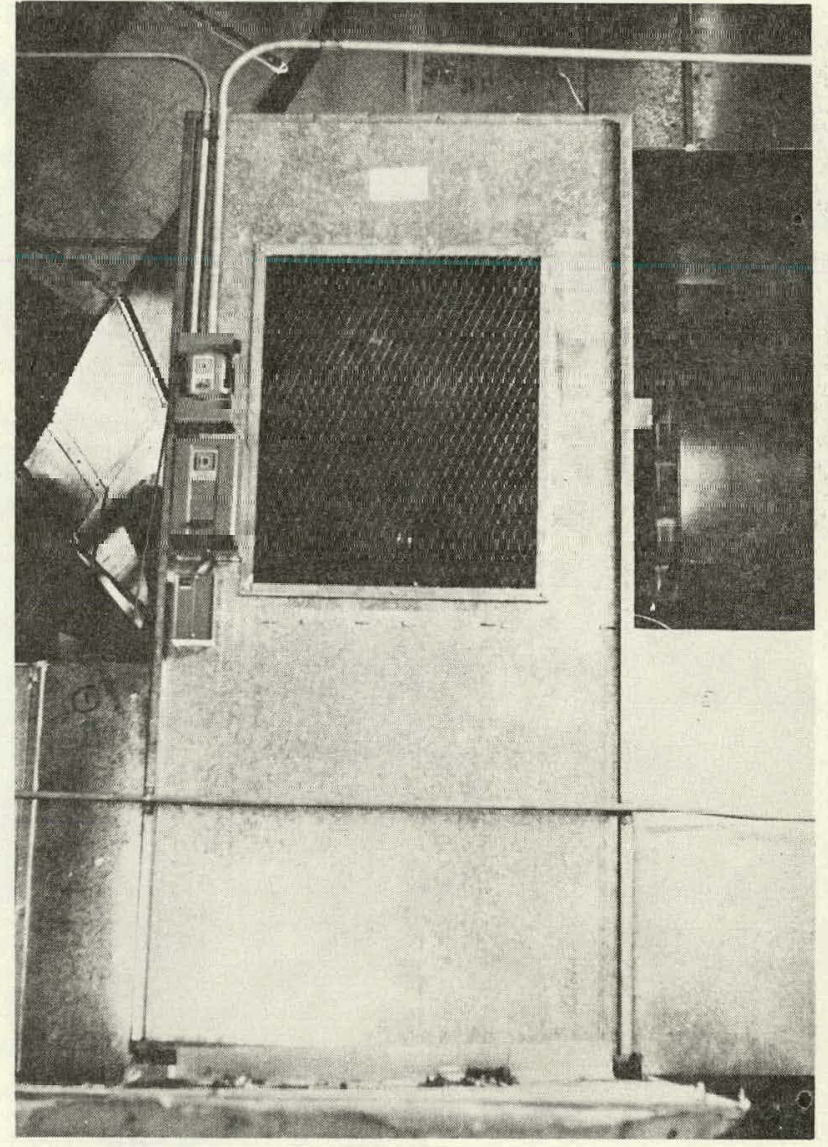

4. The air handling unit. 


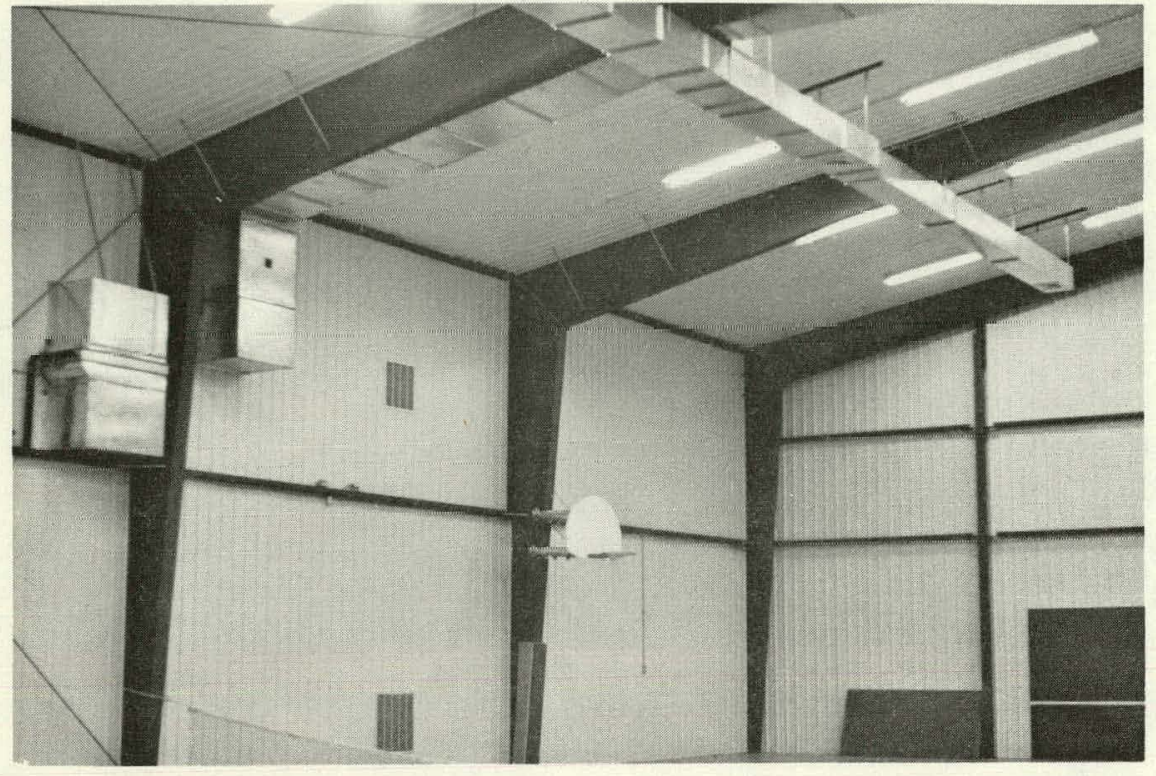

5. Interior ductwork. The heat exchanger is on the left.

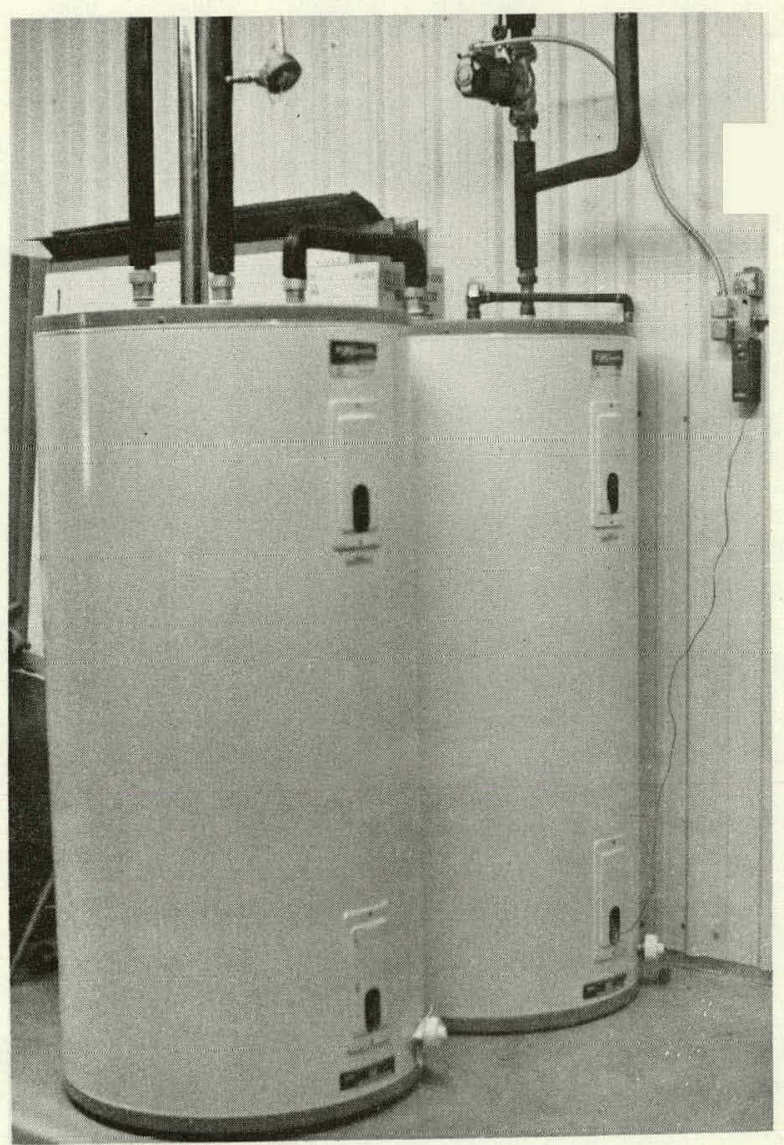

6. The hot water storage tanks. The water circulating pump is mounted above them.

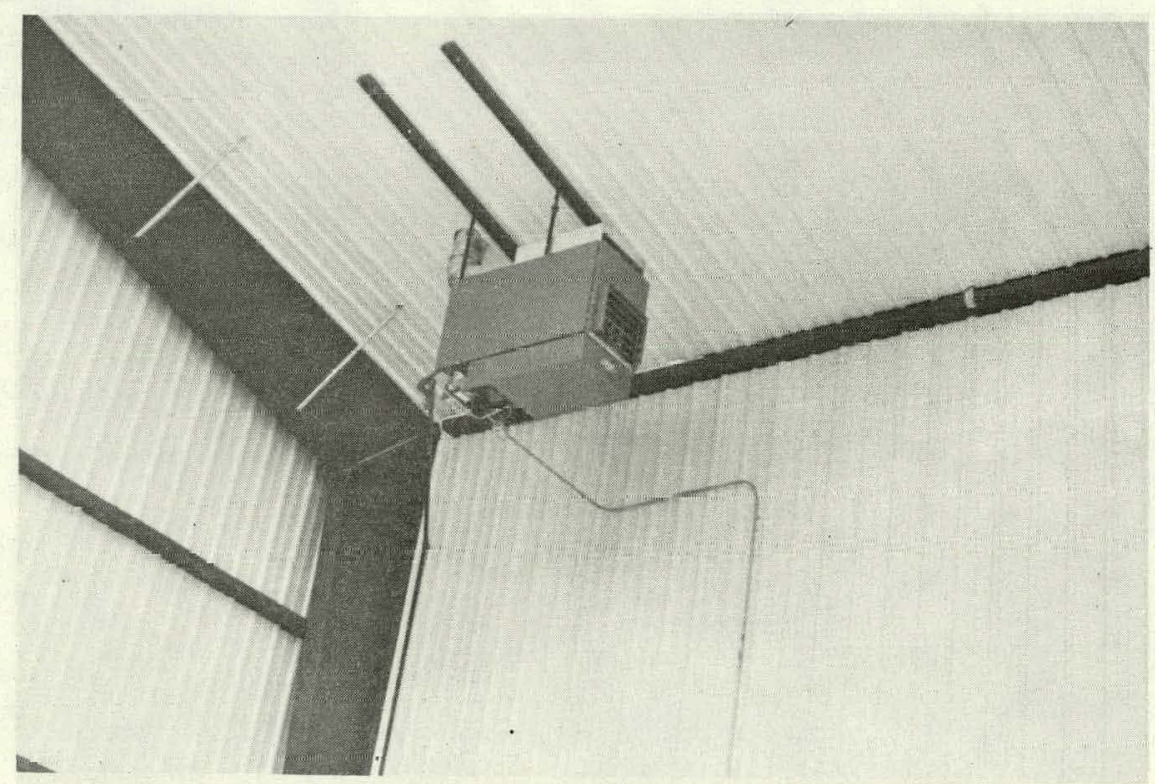

7. One of the 2 auxilliary propane heaters in the gymnasium. 


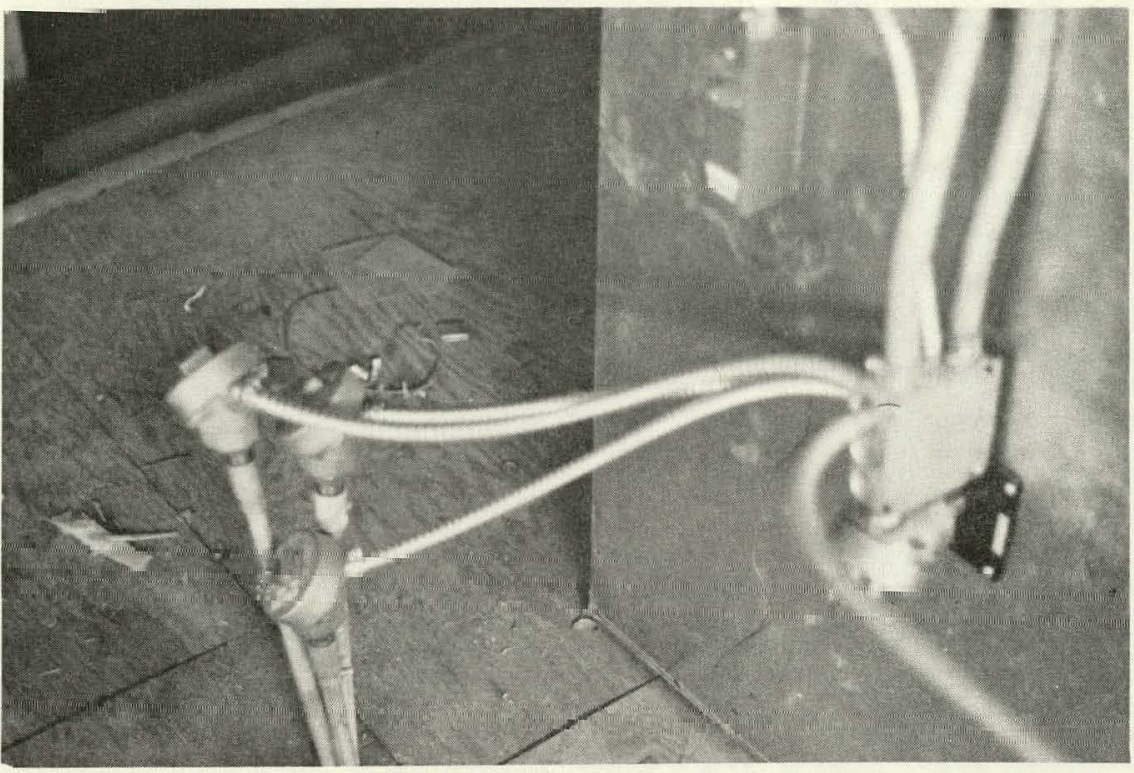

8. Three thermal sensors associated with the rock storage box.

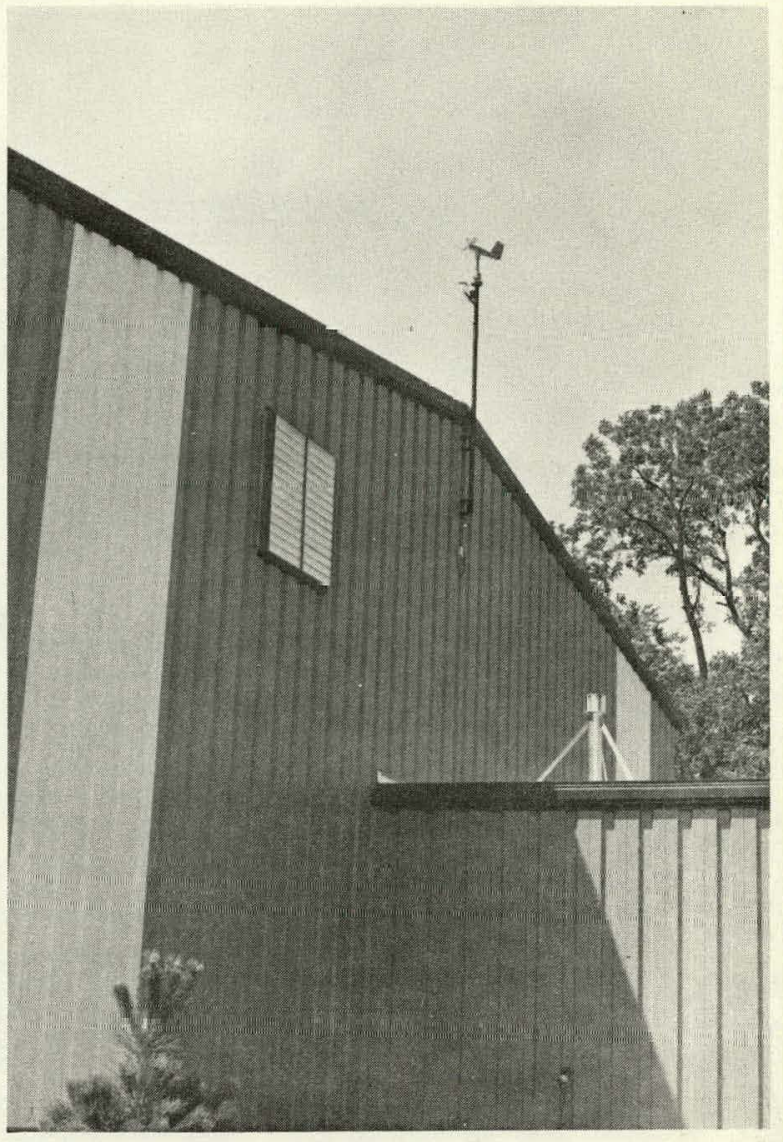

9. The wind speed, wind direction, outside ambient temperature and humidity sensors mounted above the building.

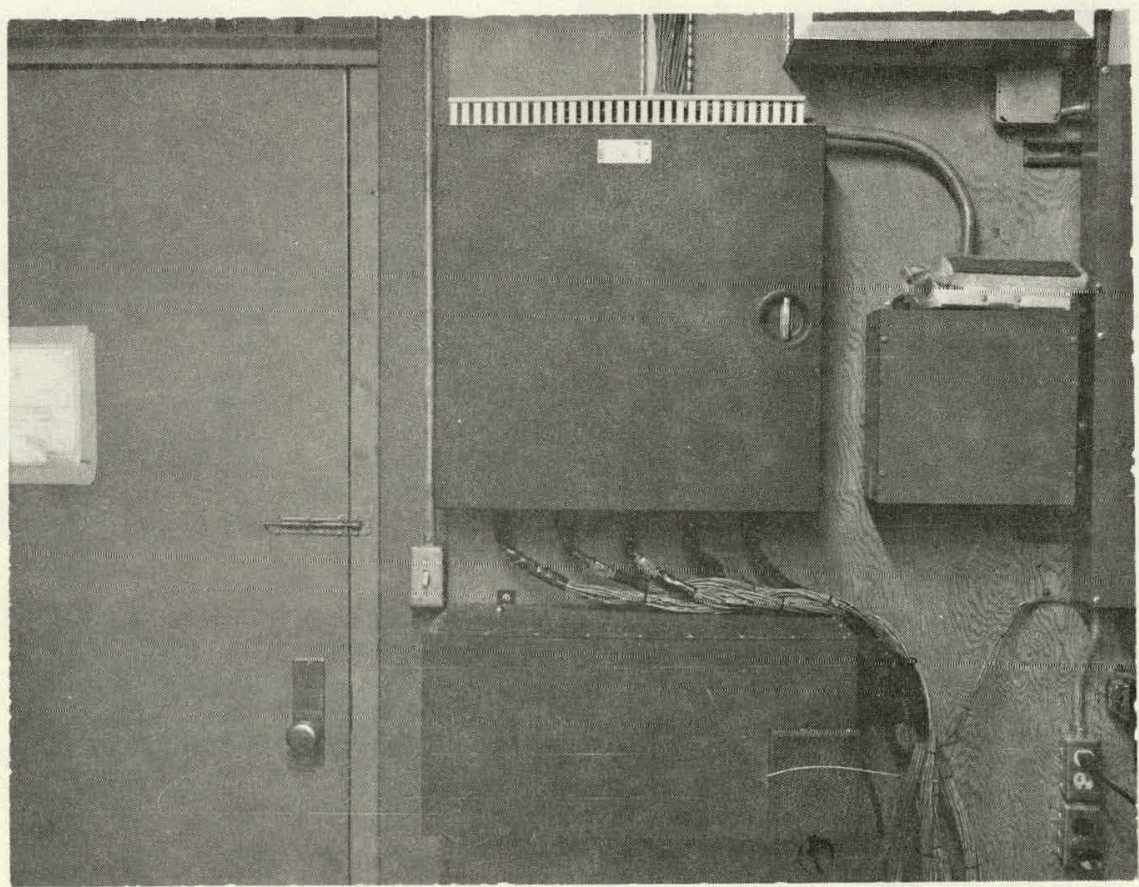

10. The junction box (upper center) for the data acquisition sensors with the Site Data Acquistion Subsystem (SDAS) below it. 


\section{B. Modes of Operation}

The system has six modes of operation.

1. Heating the building with hot air from the collector.

2. Storing heat by drawing heat from the collector through the rock box.

3. Heating the building with heat stored in the rock box.

4. Heating water by drawing air from the collector past heat exchange coils and back to the collector. In this mode the building and the rock box are bypassed. Water heating also occurs during modes (1) and (3).

5. Venting the collector by opening slide gate dampers in the ductwork to permit the collector to vent by natural convectinn.

6. Heating with the auxiliary system. When the heating requirements of the building are more than can be supplied by the solar heating system, the auxiliary heaters automatically come on and provide the needed heat.

A schematic of the heating system and the first (4) modes of operation dre shown in firgures 1 - 5. Heavy lines indicate air flow.

Further details of the solar heating system, including as-built drawing and diagrams, a dnscrintion of lidriware, a detailed sequence of operations, and maintenance instructions are found in Appendixes B - F. 


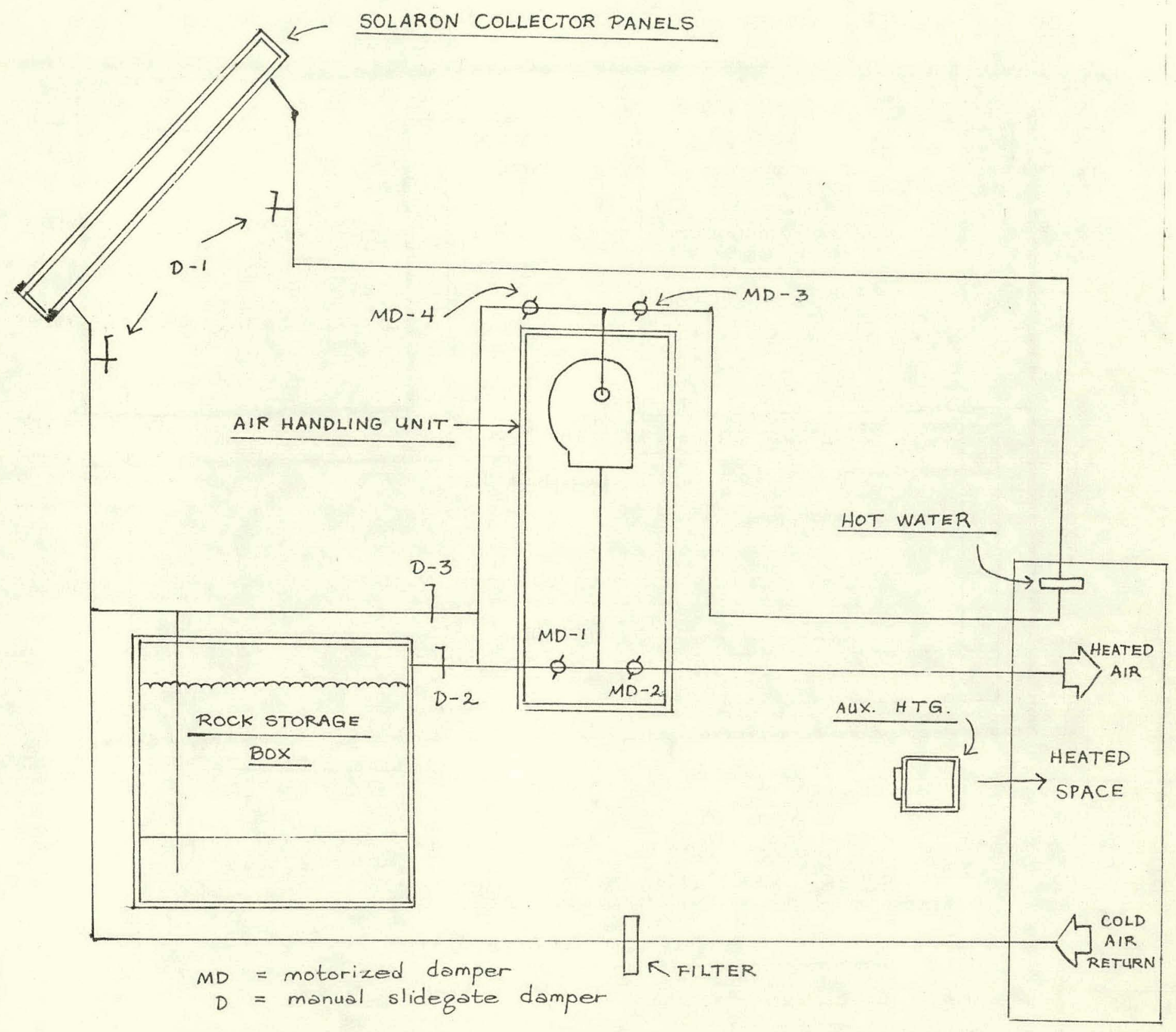

FIGURE 1: Schematic drawing of the Solar Heating System 


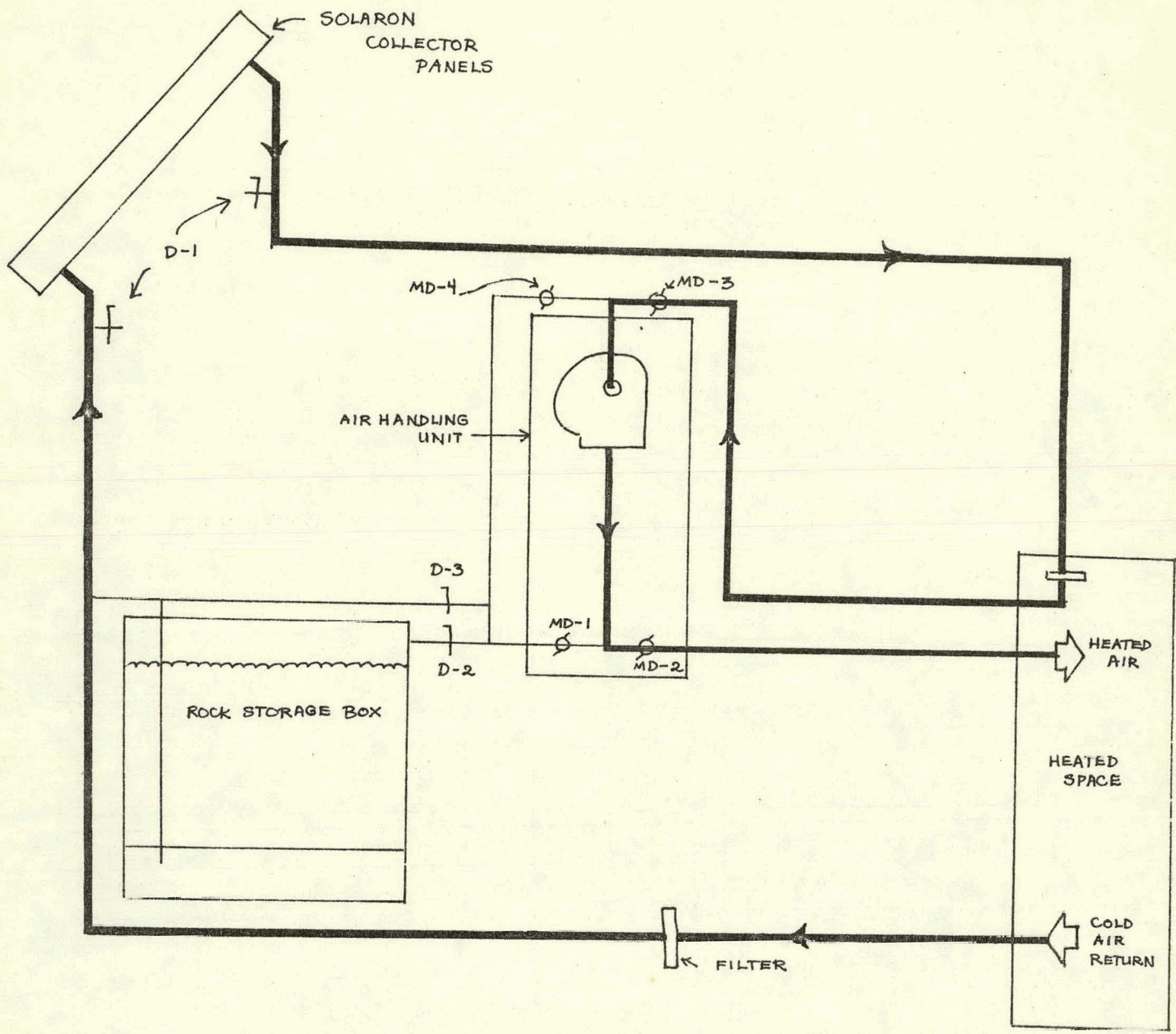

SOLAR hEATING Flow SCHEMATIC.

SEQUENCE OF OPERATION

$O=$ OPEN $C .=C I O S E D$

\begin{tabular}{c|c|c|c|c|c|c|c|c}
\hline MODE & $M D-1$ & $M D-2$ & $M D-3$ & $M D-4$ & $D-1$ & $D-2$ & $D-3$ & \\
\hline HEATING FROM COLLECTOR & $C$ & 0 & 0 & $C$ & $C$ & 0 & $C$ &
\end{tabular}

FIGURE 2: Mode 1 - Heating from the Collector 


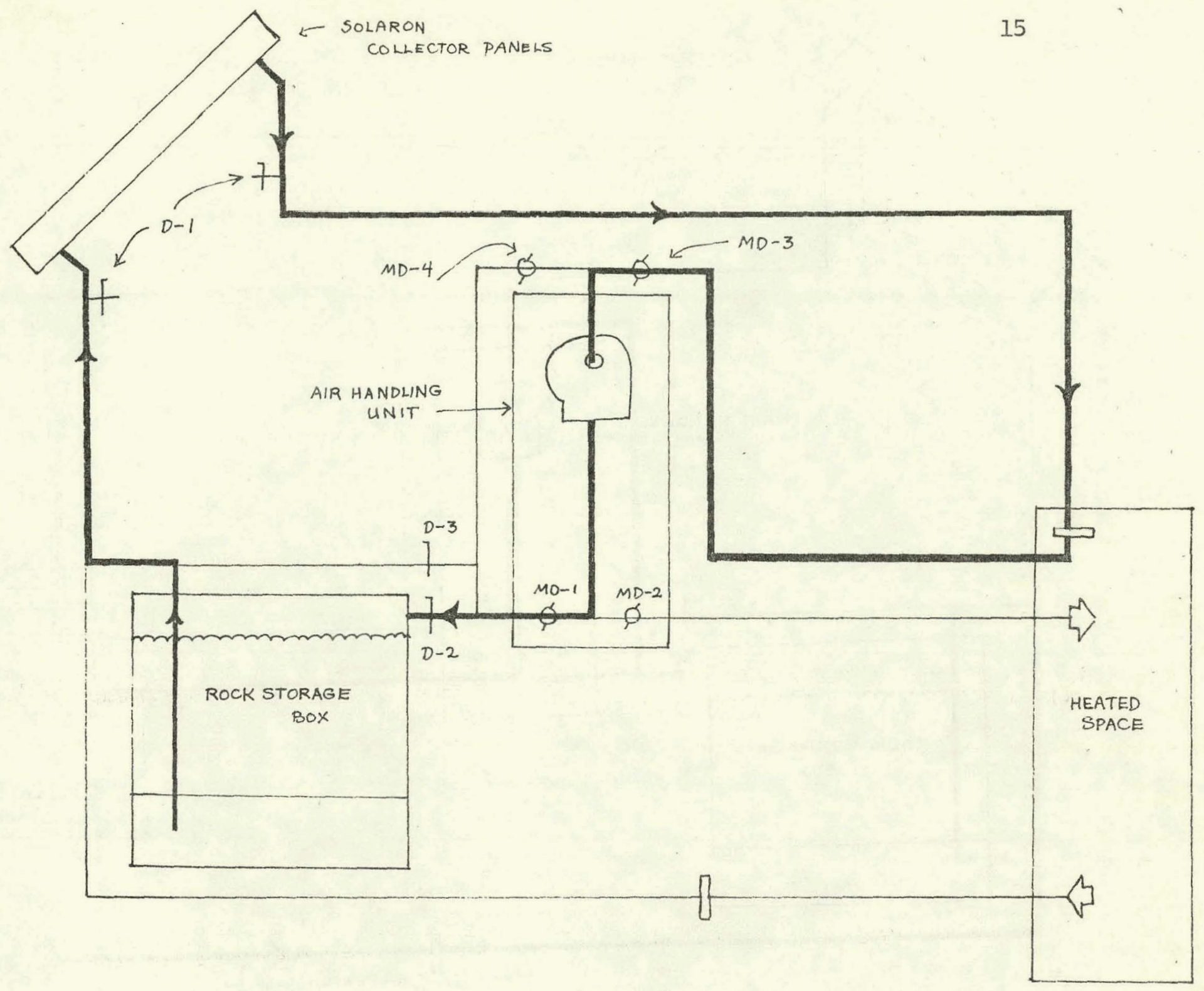

SULAR HEATING FLOW SLHEMAIIC
SEQUENCE OF OPERATION

$O=O P E N \quad C=C L O S E D$

\begin{tabular}{c|c|c|c|c|c|c|c|} 
MODE & $M D-1$ & $M D-2$ & $M D-3$ & $M D-4$ & $D-1$ & $D-2$ & $D-3$ \\
\hline STORING HEAT & 0 & $C$ & 0 & $C$ & $C$ & &
\end{tabular}

FIGURE 3: Mode 2 - Storing heat in the Rock storage Box 


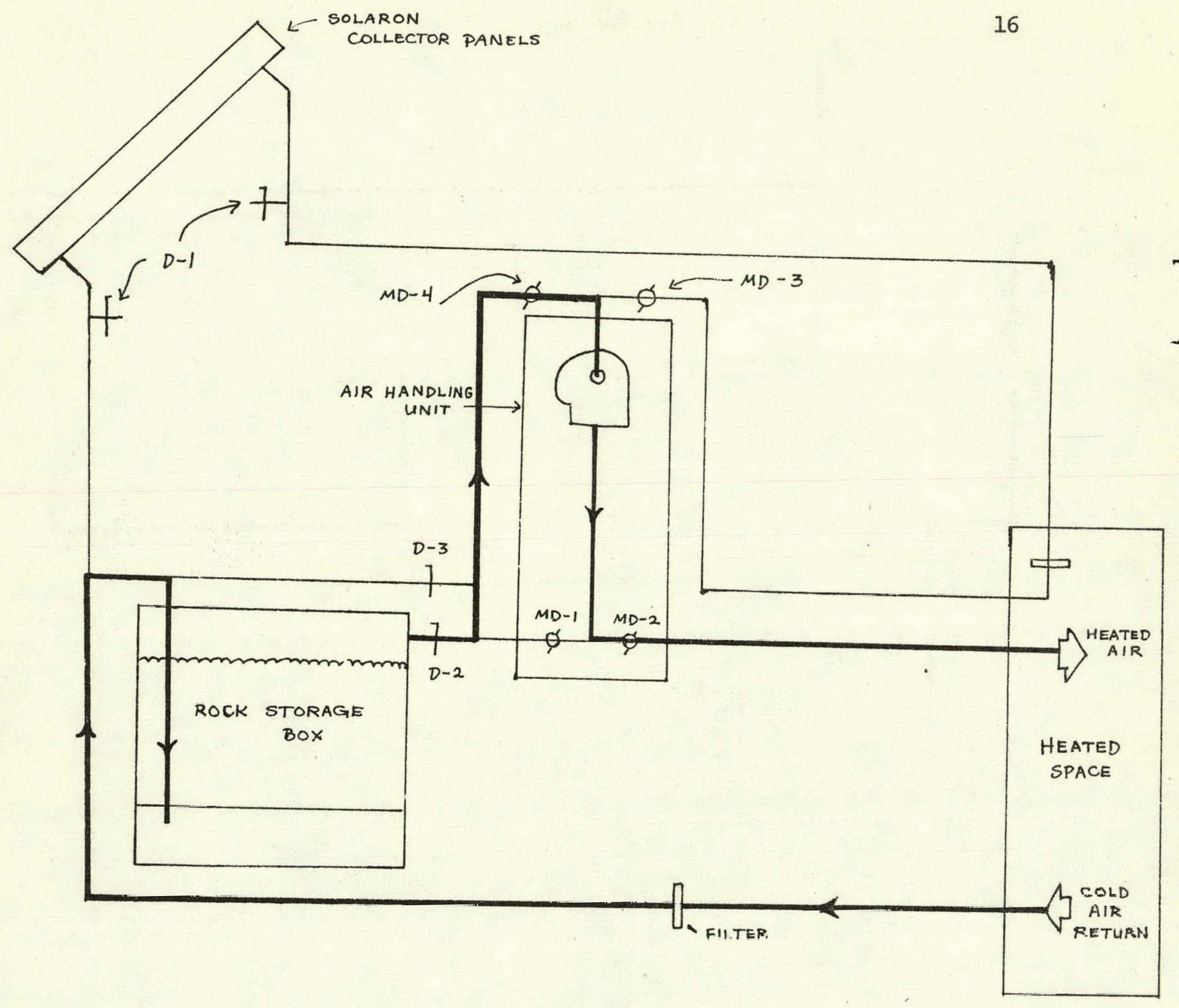

SOLAR HEATING FLOW SCHEMATIC

SEQUENCE OF OPERATION

$O=$ OPEN $C=$ CLOSED

\begin{tabular}{c|c|c|c|c|c|c|c|c}
\hline MODE & MD-1 & $M D-2$ & $M D-3$ & $M D-4$ & $D-1$ & $D-2$ & $D-3$ & \\
\hline HEATING FROM STORAGE & $C$ & 0 & $C$ & 0 & $C$ & 0 & $C$ &
\end{tabular}

FIGURE 4: Mode 3- Heating from the Rock Storage Box 


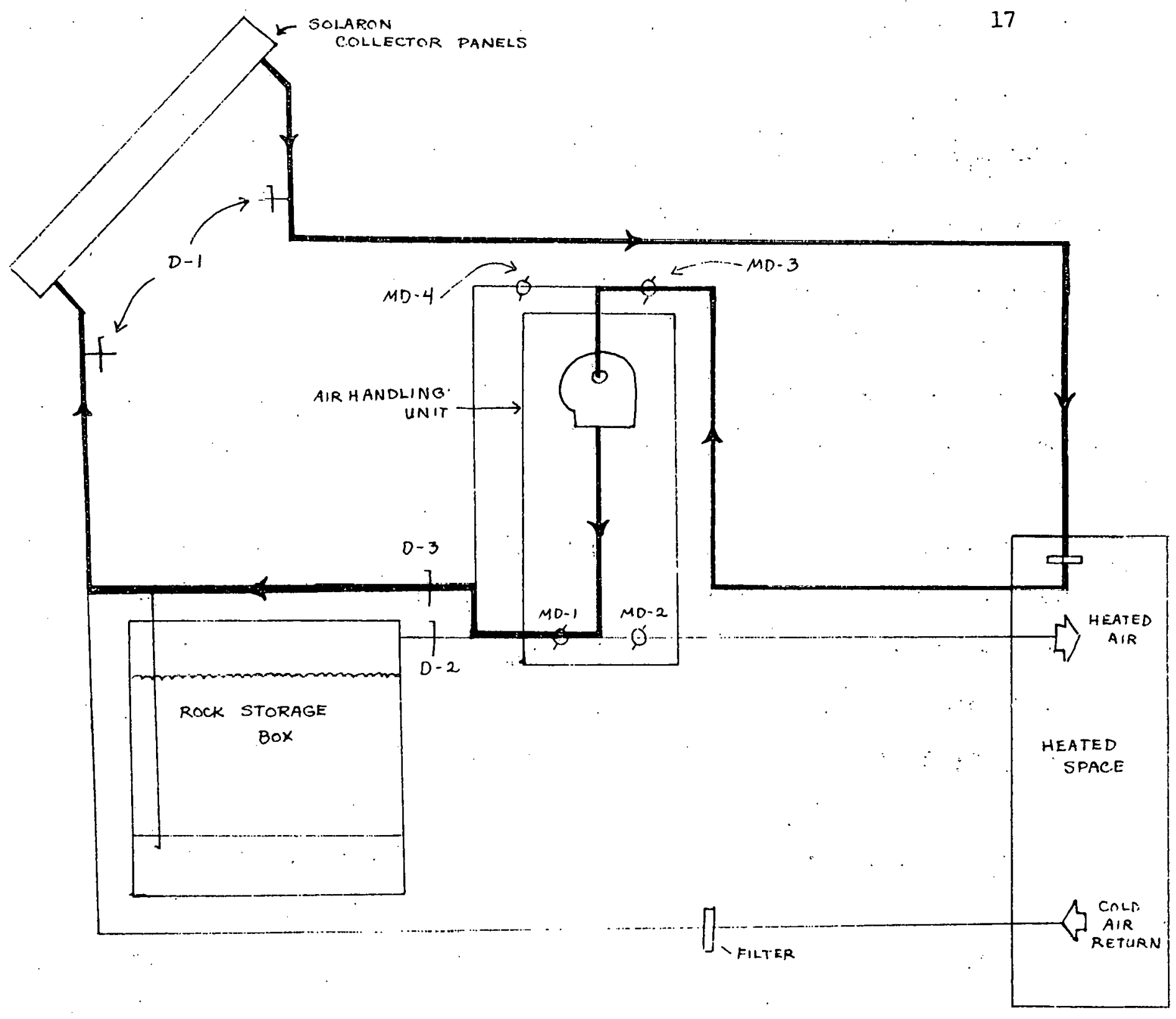

SOLAR. HEATING FLOW SCHEMATIC

SEQUENCE OF OPERATION

$O=$ OPEN $C=$ CLOSED

\begin{tabular}{c|c|c|c|c|c|c|c|}
\hline MODE & $M D-1$ & $M D-2$ & $M D-3$ & $M D-4$ & $D-1$ & $D-2$ & $D-3$ \\
\hline WATER PRE - HEAT (SUMMER) & 0 & $C$ & 0 & $C$ & $C$ & $C$ & 0
\end{tabular}

FlGURE 5: Mode 4- Heating water only (summer) 
V. HISTORICAL NAKKAIITE OF THE PROTECT

In April, 1976, Scattergood School was informed that its proposal had been accepted, and in June, 1976 a contract was awarded to the school. The contract stipulated that the school would construct the solar heating system as proposed, and that ERDA would provide $\$ 76,289$ or $88 \%$ of the total $\$ 86,692$ estimated cost.

Construction began immediately. Listed below is the schedule of construction activities as they occured. Included in parentheses is the schedule as originally proposed. A short commentary on each activity is also included.

1. Site preparation -- May-June, 1976 (April, 1976). Most of the site preparation was carried out in conjunction with the site preparation of the gymnasium itself. Origingally scheduled for April, it was postponed until May because of wet, soft ground. Some ddditional sitc prcparation for the rock storage box was carried out in June.

2. Pouring the concrete foundation - June, 1976 (May, 1976).

A concrete foundation for the collector support structure was poured soon after site preparation had been completed.

3. Red iron erection - July, 1976 (June, 1976). Five specially fabricated columns were bolted to the foundation and to the five load-bearing columns of the south wall of the gymasium.

4. Design Reviews - August, 1976.

A final design review was held at the school on August 4, 1976. A 
relatively small but significant change was made in design of the air handling system to permit a water-heating-only mode of operation that could be used during the summer when there would be no need to heat the building or charge the rock storage box.

5. Constuction of the rock storage box -- August-September, 1976 (AprilMay, 1976).

Originally scheduled as one of the earliest activities, construction of the rock storage box was postponed until after the erection of the main support colums. Reinforced concrete was used for the floor and walls of the structure. After being filled it was capped with a well-insulated, air-tight wooded lid strong enough to support the air handling unit.

6. Filling the rock storage box -- September, 1976 (May, 1976). The contractor was unable to obtain the specified 3-foot diameter, transite pipe that would serve as the duct to the bottom of the box. With Solaron's approval, a 3-foot diameter sewer pipe was used. This alteration delayed the activity; it was not until September, 1976 that the box was filled with 65 tons (1250 cubic feet) of $3 / 4$ inch, washed river gravel. Three half-inch metal conduits with holes drilled in the bottom 3 inches to facilitate air flow were installed at the bottom, middle and top of the rock bed as the box was being filled. They were long enough to project about a foot above the lid of the box. At a later date, 3 thermal sensors were installed in these 3 conduits as part of the data acquisition system.

7. Installation of collector support structure -- September-November, 1976 (May-June, 1976).

This activity provided another of the maddening delays that were 
encountered during the course of the project. The support structure consists of 3/4-inch plywood screwed to steel perlins that are bolted every 4 feet to the steel columns. To facilitate mounting of the plywood, a special self-tapping, self-countersinking screw was used. The contractor ordered 1000 of these screws, thinking that 10 screws per plywood sheet would be enough. It was found during construction that 14 screws per sheet were needed, hence only 70 of the 100 sheets were mounted after the rock box had been filled. The contractor was unable to abtain additional screws until the end of October. The project was delayed an additional 6 weeks.

8. Installation of the solar collectors - November, 1976- Febraury, 1977 (Jume-July, 1976).

The collector array consists of 128 solar panels arranged 4 high and 32 across. About 90 of the panels were mounted during the last warm weather of the year, which was in Nuviliuer. Once freezing weather set in, panel installation ceased; the butyl rubber tape used to seal the connection between panel unit has poor flow and arhesion properties below $40^{\circ} \mathrm{F}$. Not until February, 1977 were there a few consecutive days warm enough to erimelte the installation.

Installation was more time consuming than anticipated, in part because of the size of the array. Although the panels function as separate units of 8 because of the placement of the ducts leading to and returning from the array, all of the units are interconnected. In order to achieve an airtight system, alignment had to be exact, with little margin for error. Much time would have been saved if the collectors 
had been equipped with off-set pins to let the workman know when the collector was in exact alignment. Time might also have been saved if the collectors had been placed as 4 units of 32 with narrow separators, such as 1-inch by 6-inch lumber, rather than as a monolithic array.

9. Installation of the air handling system -- December, 1976-May, 1977 (June-July, 1976).

Ductwork inside the building was fabricated and installed during the month of December. The major part of the air handling system, located beneath the solar panels, was completed during the late winter and early spring. The custom-made blower and fan installation was received in December and positioned on the rock storage box. Ductwork was then located around it. Fiberglass duct was found to be most satisfactory and was used where ever possible. Where sheet metal ductwork had to be used, all joints were sealed with silicone rubber.

10. Installation of water preheat system -- April, 1977 (July, 1976) . The water preheat system was installed during the last 2 weeks of April, 1977. Two insulated, glass-lined, 120-gallon tanks were installed in series in such a way that an aquastat controling a pump moving water in a loop between the storage tanks and the heat exchanger would continue to operate until the water in both tanks had reached a predetermined temperature. Valves were installed to permit the domestic water heater alone, the solar water heater alone, or the $2 \cdot$ in combination to provide hot water.

11. Wiring and installation of control sensors -- Apri.l-May, 1977 (July, 1976). Most of the installation of control sensors and wiring was done when the monitoring sensors were installed and wired. 
12. Start-up -- May, 1977 (July, 1976).

The system was first operated and checked out by the Solaron Corporation field engineer assigned to the project during the week of May 16. Because a slide gate damper was incorrectly positioned, he was able to test the system in only 4 or the 5 modes of operation. A number of air leaks were found in the ductwork, and other minor items needed to be corrected.

13. Open House -- May, 1977.

An open house for the solar heated recreation building was held on May 21, 1977. Senator Richard Clark (D-Iowa); the congressional representative from our district, Michael Blouin; Robert Bauer, head of ERDA's Chicago Operations, made short presentations to a group of about 200 .

14. Acceptance test - June, 1977 (July 1976).

The acceptance test of the solar heating system was conducted by a Solaron field engineer during two visits in May and June, 1977. After. the second visit the system was judged to be acceptable upon completion of a number of minor corrections. Details of the test plan and test data are found in Appendix $\mathrm{H}$.

15. Installation of monitoring equipment -- April-June, 1977.

In February, 1977 the dollar amount of the contract was increased by $\$ 7,076$ to provide for the installation and wiring of monitoring sensors as part of a data acquisition system. A total of 31 government fumished sensors were installed and wired during April and May, 1977. During the week of Jume 13, personnel from the IBM Corporation installed the Site Data Acquisition System (SDAS) and made the necessary connections to pemit the data to be relayed by telephone to Huntsville, Alabama da: 
Because the SDAS had been badly damaged in shipment, a second visit by an engineer from IBM during the week of Jume 30 was required to make the data collection system function properly: Both the solar heating system and the data collection system are now fully operational.

16. Bottlenecks

Three serious bottlenecks were encountered during the project. Two had a significant impact on the construction schedule. The third did not because of the large delays that had already occurred.

Completion of the rock storage box. Because the rock storage box would no longer be accessible once the collector support structure was erected, the box had to be filled with rock and capped with an airtight lid before the next phase of the project could be undertaken. A few weeks of delay in the completion of the rock storage box resulted in a few weeks delay in the project.

Installation of the solar panels, including the support structure. A key delay in the construction of Scattergood School's solar heating system resulted from delays in the construction of the panel support structure and, as a result, an even longer delay in the installation of the solar panels. Had the panels been completed during the winter. Instead, installation of ductwork under the collector array began in Febraury and was not completed unitl May, 1977. 
Installation of the air handling unit. Because key parts of the ductwork are built around this fan and blower unit, a considerable amount of the duct installation was not begun until the air handling unit had been correctly positioned on the top of the rock storage box. First scheduled for delivery in September, the air handling unit arrived in early December. In Scattergood's case the delay did not affect the construction schedule because all of the solar panels had not been mounted. Otherwise, later arrival of this piece of key equipment would have delayed the project.

17. "Surprises".

Besides shipping delays, there were other things that we failed to anticipate or that we badly miscalculated in our planning. Some of these are mentioned below.

Unloading the solar panels. Ten tons of panels had to be unloaded from a moving van: With neither an unloading dock nor a fork-lift truck on. hand, the building conetruotion orew epent the better part of a day at. this activity.

Filling the rock box. There was not room for a truck to unload directly into the box as had been planned. Instead, a front-end loader had to be used to transfer the rock to the box from a plle some distance away. This activity took most of a day.

Wiring the solar heating system. Wiring the systen was far nure tinim consuming and expensive than had been anticipated. One reason for this 
was that the work did not readily dovetail with the installation of the SDAS sensors, as had been hoped, and therefore was done separately.

Installation of the ductwork. Installation of all of the ductwork associated with the system took about 10 weeks, rather than the 3 or 4 that had been anticipated. Some of this time could probably have been saved if the contractor had used round ductboard where ever possible, rather than constructing the ductwork from insulated sheet metal. In any case, the requirement for a completely air-tight system was a new experience for the contractor and was considerably more time-con-. suming than he had planned.

18. Testing period.

Following the formal acceptance test in June, 1977, the next 6 months were used to check out the system and make any modifications or corrections needed to improve the system's performance. The following corrections or changes were made.

- Leaks in the ductwork that were not detected during construction . were plugged.

- Two valves were added to the water preheat system so that the heat exchanger could be isolated from the rest of the system. This change was made so that the volume of water used in the building could be measured by the SDAS even though the heat exchanger was disconnected for cleaning and repair.

- A larger disconnect box was placed on the air handling unit to eliminate a problem of the fuse blowing every few days during hot weather. 
- Motorized dampers, found to be out of adjustment, were correctly adjusted so that air would not flow through the collector when the system was heating from storage.

- Ductwork. was added to the system so that the collector could be used to dry grain raised by the school for its livestock. A report of this modification can be found in Appendix J.

- The two propane unit heaters providing back-up/auxilliary heating for the yymmasium were wired to the control panel and tested.

- Double deflection diffusors, installed to distribute air inside the gymasium, were replaced with double deflection registers. 
VI. DESCRIPTION OF THE DATA ACQUISITION SYSTEM

In order to obtain information necessary for evaluation of the performance and operation of the solar heating system throughout the year, 31 sensors were installed within the system. These sensors were furnished by the govermment and installed at government expense in accordance with the document, "SHC-1006, August 4, 1976; Instrumentation Installation Guidelines for the National. Solar Heating and Cooling Demonstration Program." In Table 2, each sensor is listed by a code designation and by the parameter measured. The number: sequence in the code indicates the data groups in accordance with the following table:

Number Sequen
001 to 099
100 to 199
200 to 299
300 to 399
400 to 499
500 to 599
600 to 699

Data Group climatological collector thermal storage domestic hot water space heating space cooling building/load

Each sensor provides data to a Site Data Acquisition Subsystem (SDAS) every 5 minutes around the clock. The SDAS digitizes the data and stores it on tape. Once a day the data is sent by telephone to an IBM facility in Hunt.sville, Alabama, where it is reduced. Monthly reports are prepared, one of which is sent to scattergood School.

The monitoring system will permit the government to determine the following kinds of information:

- Savings in conventional energy resulting from the use of solar energy for heating and/or coiling. 
- Portion of the total heating and/or cooling load supplied by the solar energy.

- Efficiency of the system in converting solar radiation into useful thermal energy.

- Thermal performance and reliablilty of major subsystems or components over the demonstration period.

It is anticipated that information abtained from the data acquisition system will also be used by Scattergood School students for science projects in earth sciences, physics and chemistry.

Table 2 describes each sensor in terms of its general location and the parameter that is being measured. The specific location of each sensor can be found in the as-built drawing of the system found in Appendix $C$. 
TABLE 2

INSTRUMENTATION FOR SCATTERGOOD SCHOOL DATA ACQUISITION SYSTEM

Designation

A. Climatological

$\mathrm{RH} 001$

D 001

$\mathrm{V} 001$

I 001

T 001

B. Collector

T 100 .

TD 100

T 101

TD 101

T 102

W 100

E 101

C. Thermal Storage

T 200

T 201

T 202

D. Domestic Hot Water

T 302

TD 302

T 304

TD 304

T 305

T 306

TD 306

W 302

W 306

EP 301

EP 300

E. Space Heating
T 402
TD 402
W 400
F 400
EP 402

F. Building/Load

T 600
Measurement

Outside ambient relative humidity

wind direction

wind speed

Solar flux

outside ambient temperature

collector array inlet temperature

Collector array differential temperature Rock storage outlet temperature Rock storage differential temperature

collector surface temperature

collector array air flow

Circulating air fan power

Rock storage tenperature - top

Rock storage temperature - middle

Rock storage temperature - bottom

Temperature of outlet hot water preheat coil

Differential temperature across preheat coil $(+\Delta \mathrm{T})$.

Temperature of inlet preheat tank

Temperature differential across preheat tank T'emperature of $001 \mathrm{l}$ water supply

Temperature of domestic hot water inlet

Differential temperature across domestic hot water tank

Domestic hot water preheat loop flow rate

Preheat tank to domestic hot water tank flow rate

Preheat tank circulating pump power

Domestic hot water heater electric power

Space heating inlet temperature

Differential temperature across heated space

Air flow in return air duct of building

Propane flow to space heaters

space heaters, locker room \& utility room fan power

Inside ambient temperature 
VII. COSTS OF THE SCATTERGOOD SCHOOL SOLAR HEATING SYSTEM

Given in Table 3 are the estimated and the actual costs of the various phases of the project.

Overall, the costs were $\$ 101,522$. This figure is $\$ 7,754$, or about 8.38 , more than the original estimates. Most of the additional cost was for labor, and can be attributed to the "first time" nature of the project. Scattergood and its subcontractors were unable to visualize beforehand all that would be involved in the various phases of construction. It is significant that nearly all of the subcontractors indicated that if they were to do it again, the job would go more easily and be less expensive.

Costs were shared by the federal government and the school. The Department of Energy provided $88 \%$ of the funds to build the solar heating system and $100 \%$ of the funds to install the data acquistion system. Thus, of the total amount of $\$ 101,522$, Lile Dejartnent of Energy paid $\$ 90,250$ and Scattergood School $\$ 11,272$.

The contract was modified twice to cover cost over-rums. On September 8, 1977, the dollar amount was increased by $\$ 339$ (govermment share, 100\%) to cover additional costs associated with the installation of the site Data Acquisition Subsystem. On Novmeber 11, 1977, the contract was increased by $\$ 7,510$ (government share, $88 \%$ ) to pay for costs associated with the construction of the solar heating system. The school is grateful to the Department of Energy for its willingness to bear these additional costs. 
TABLE 3

COST OF THE SCATTERGOOD SCHOOL SOLAR HEATTNG SYSTEM

Estimated

Actual

Cost

Cost

A. Purchase of Solar Hardware

Installation plans and specifications

128 Model 2001 Solaron Collectors

1338 foot capstrip and seals

Custom air handling unit

Cost

Custom water preheat package

Less credit for direct shipment

Cost of shipment

Additional materials for installation

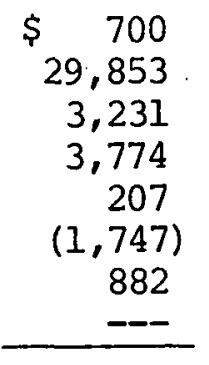

Subtotal
$\$ 700$

29,853

3,231

3,774

207

$(1,747)$

908

411

$\$ 37,337$

B. Construction of Solar Heating System

Site preparation

Collector support structure

$\$ 500$

21,650

3,737

5,000

Collector installation

9,741
2,000

Construction and installation of ductwork

$\$ 500$

21,650

4,948

7,382

Interconnect 'wiring for solar \& back-up system

Installation of water heating system

(to be paid out of contingencies)

11,711

2,000

Wiring of solar system

(to be paid out of contingencies)

contingencies

Subtotal $\quad . \$ 45,128 \quad \frac{2,500}{\$ 52,481}$

C. Project Supervision

Direct labor and overhead

Supplies and expenses

Travel

\begin{tabular}{lrr} 
& $\begin{array}{r}\$ 1,664 \\
200\end{array}$ & $\begin{array}{r}\$ 1,960 \\
195\end{array}$ \\
\cline { 2 - 3 } Subtotal & $\$ 200$ & \\
\cline { 2 - 3 } & $\$ 2,164$ & \\
Testing & $\$ 2,500$ & $\$ 1,962$
\end{tabular}

D. Field Inspection and Acceptance Testing of System

2,500

1,247

3,043

$\$ 52,481$

E. Installation of Data Acquisition System

Preparation of updated drawing of solar heating system

Installation and wiring of sensors

Project supervision
$\$ \quad 450$
6,437
189

Subtotal
$\$ 7,076$

$\$ 93,760$
$\$ \quad 450$

6,948

189

$\$ 7,58 \%$ 
VIII. WHAT WE WOULD DO DIFFERENILY IF WE WERE TO DO IT AGATN

The biggest problem with the Scattergood school project was the lack of a built-in mechanism that would permit direct interaction among the various subcontractors at crucial stages of construction. In order to alleviate this problem, we would do two things differently the second time around. 1. There would be a one-day, pre-bid conference for all the subcontractors concerned. It is particularly important to have the solar hardware subcontractor specify exactly what he will supply and what must be furnished by others. Blueprints would be explained, materials and construction methods would be gone over, and each phase of the project would be discussed. As a result, suboontractors would have a clear idea of what they would have to furnish and the things they would have to do. It might be arghed that all of this occurs during the Design Review. By then, however, at least in our case, it was too late. Bids had already been submitted and accepted and construction had begun.

2. There would be a much greater insistence that building subcontractors interact directly with the solar subcontractor when confronted with difficulties or when making important decisions. Perhaps a line item in the subcontract for telephone calls would facilitale such cormmication. The pre-bid conference also would lay the groundwork for this kind of interaction. Direct communication would have avoided a number of schedule delays, poor decisions and nut.ri.ght mistakes that had to be corrected during construction. It would have saved the project manager a great deal of time serving as a go-between and would have made the project run more smoothly. 
IX.

INTERTM PERFORMANCE CRTTERTA

CERTIFICATION

CONTRACT No. EX-76-C-01-2386

DEMONSTRATION CONTRACTOR

SCATTERGOOD SCHOOL

SYSTEM LOCATION

WEST BRANCH, IOWA 52358

SYSTEM TYPE

SPACE HEATING AND HOT WATER

I certify that this solar system comples with the IPC Document No. 98 M10001

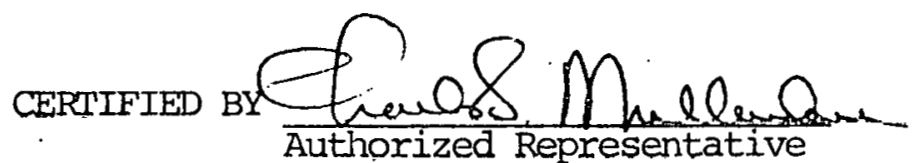

DATE Jamenay 3,1978 
APPENDIX A

BUIIDIING DRAWINGS 


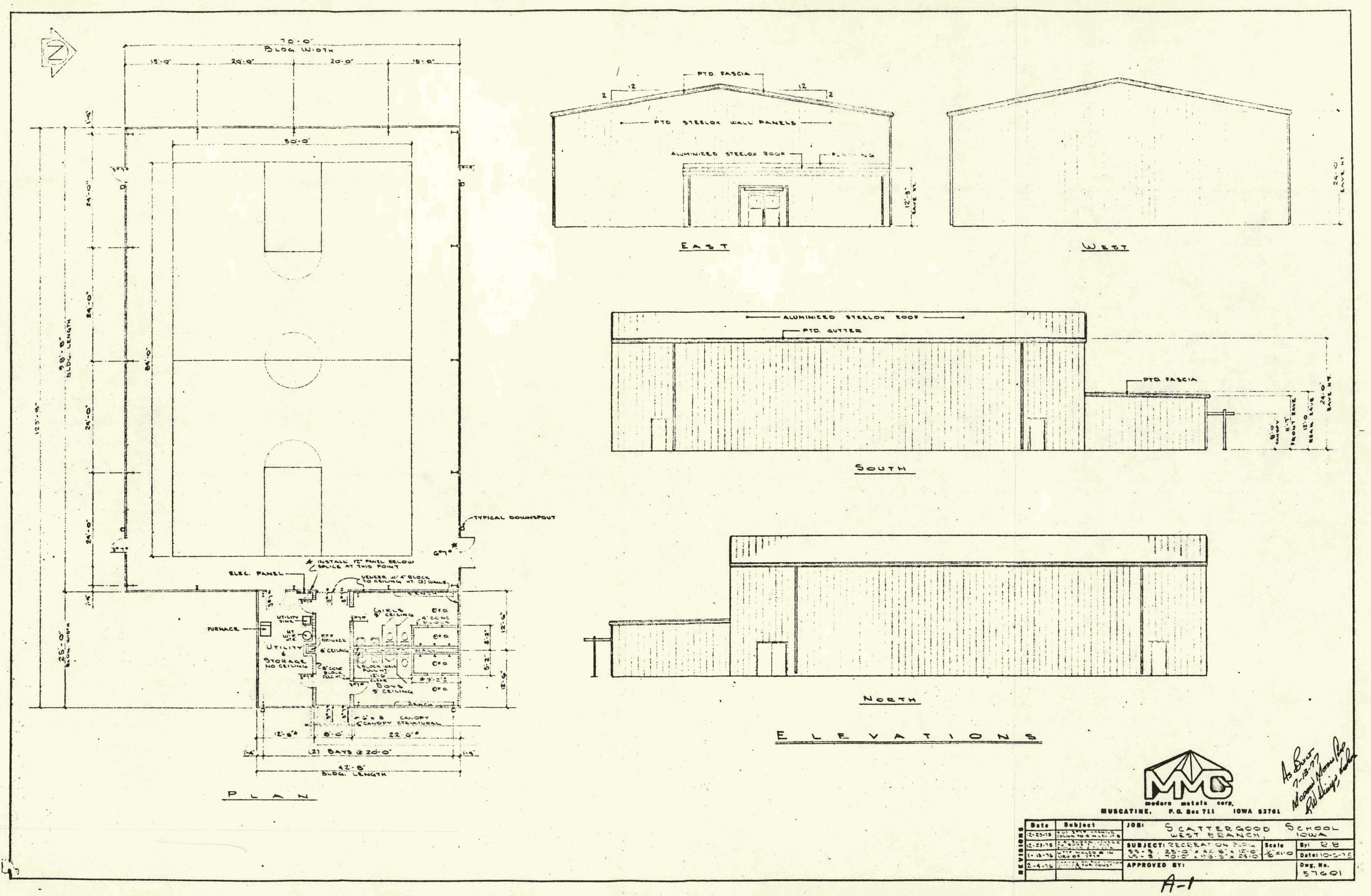




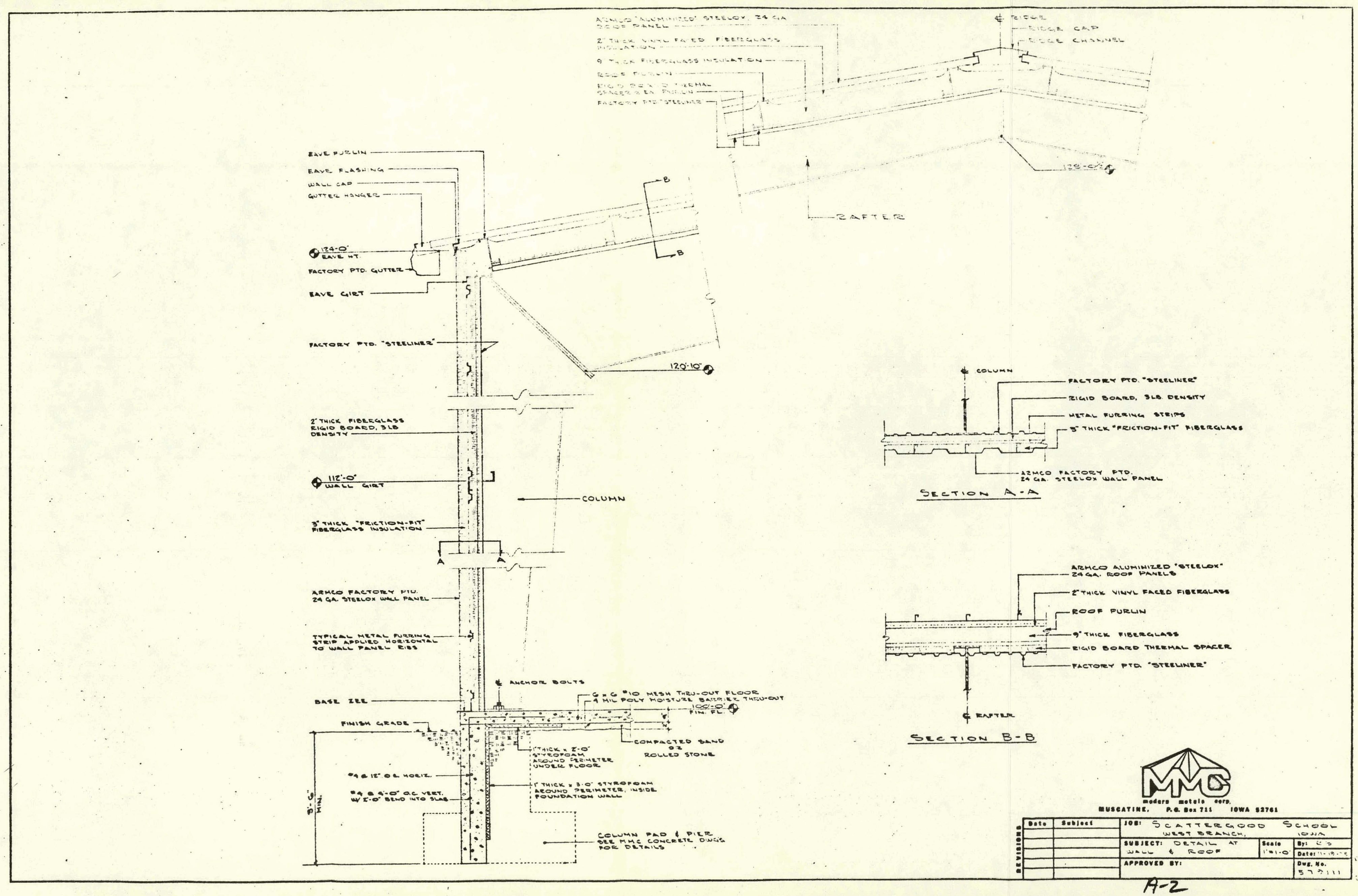




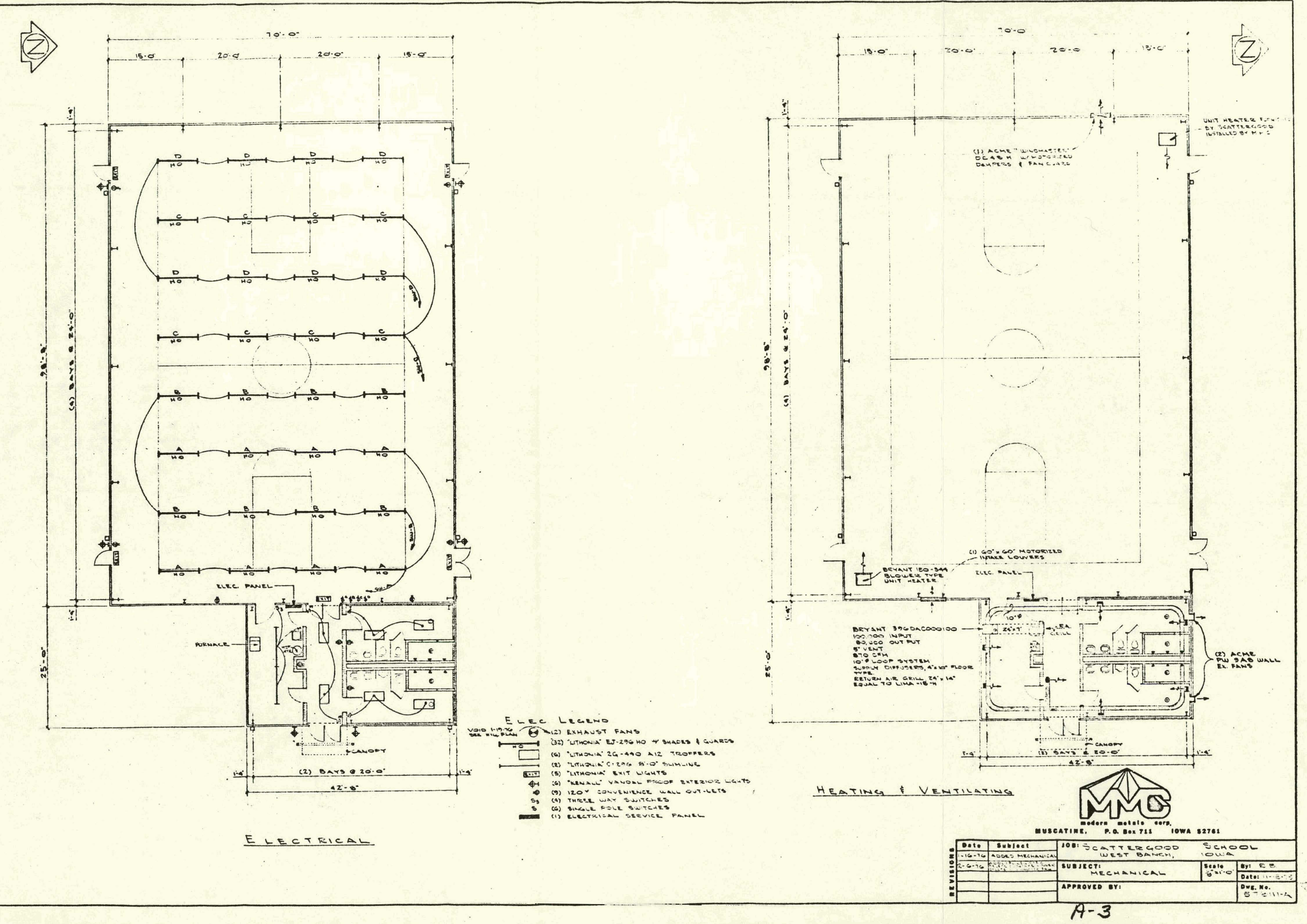




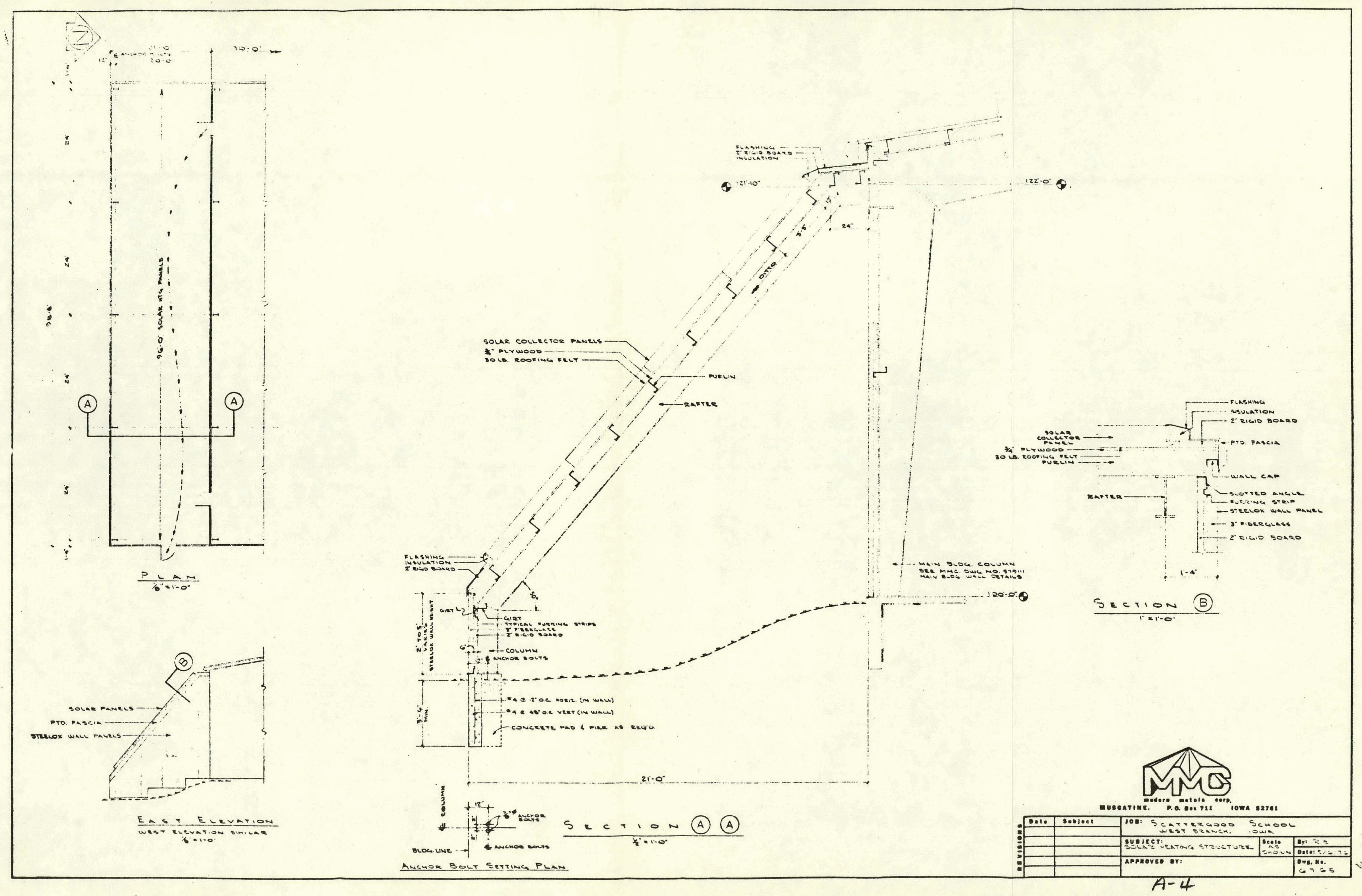


APPENDIX B

DESIGN AND SCHEMATIC DRAWINGS OF THE SOLAR HEATING SYSTEM 


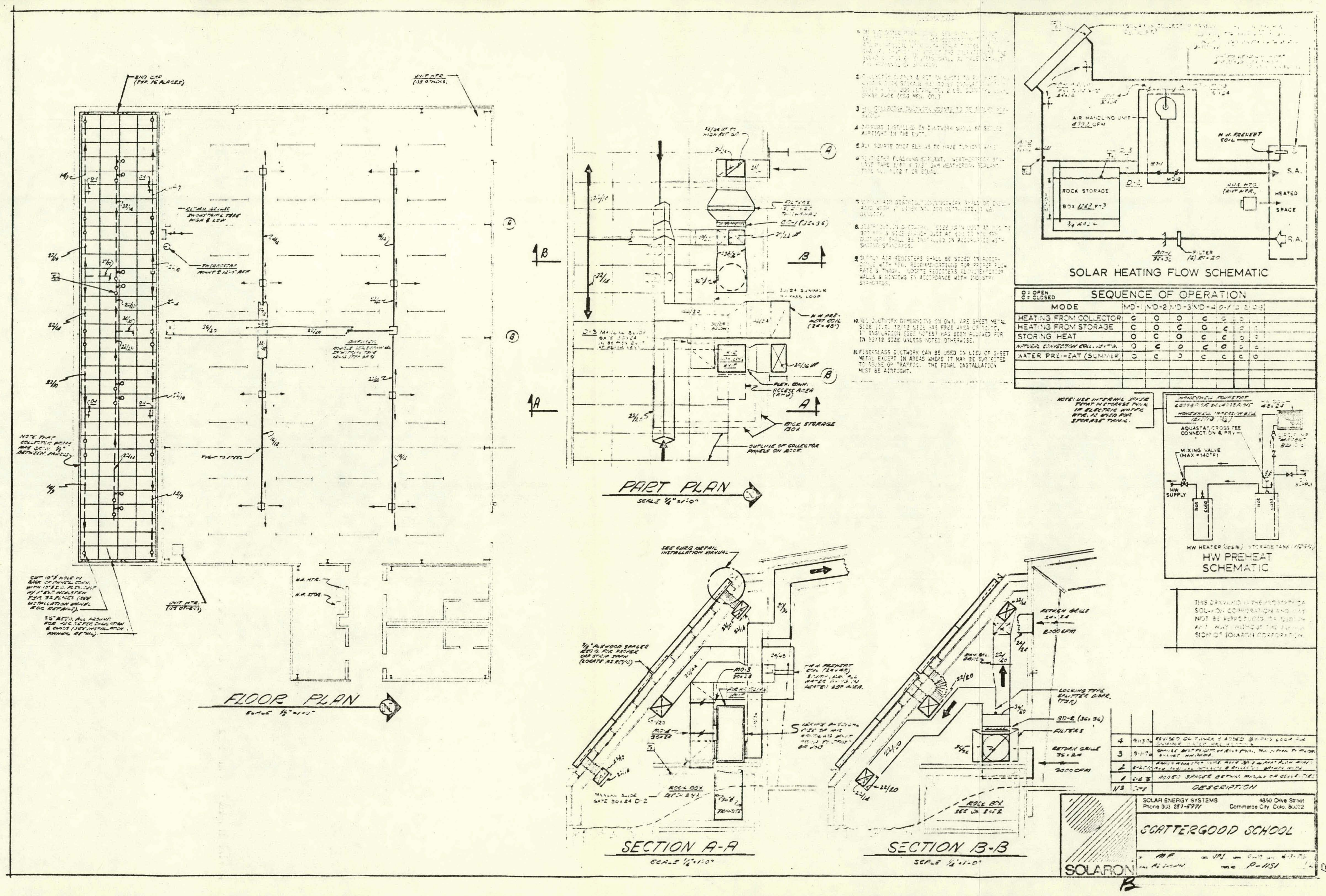


APPENDIX C

AS BUIUT DRAWINGS OF THE SOIAR HEATING SYSTEM 


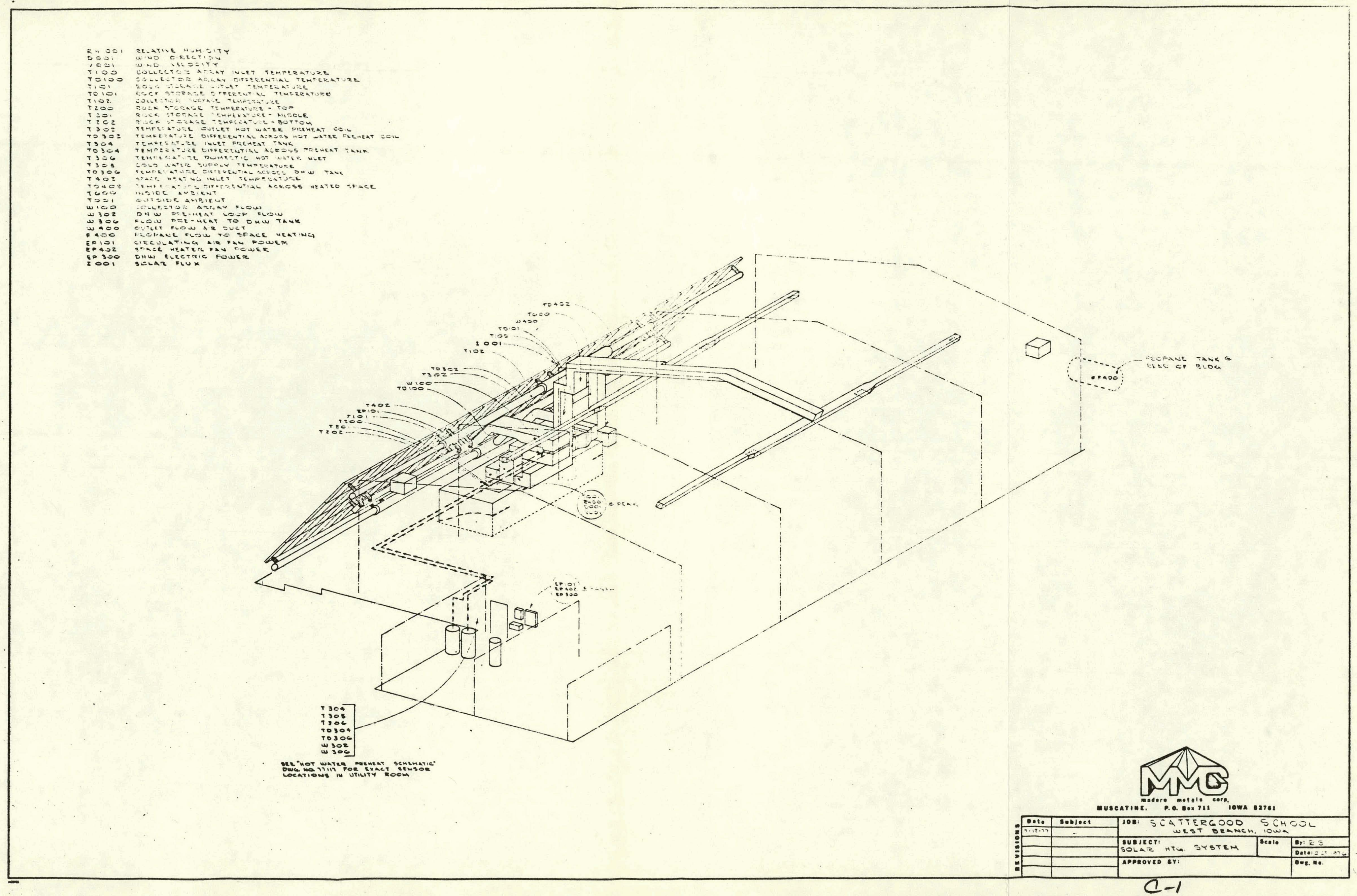




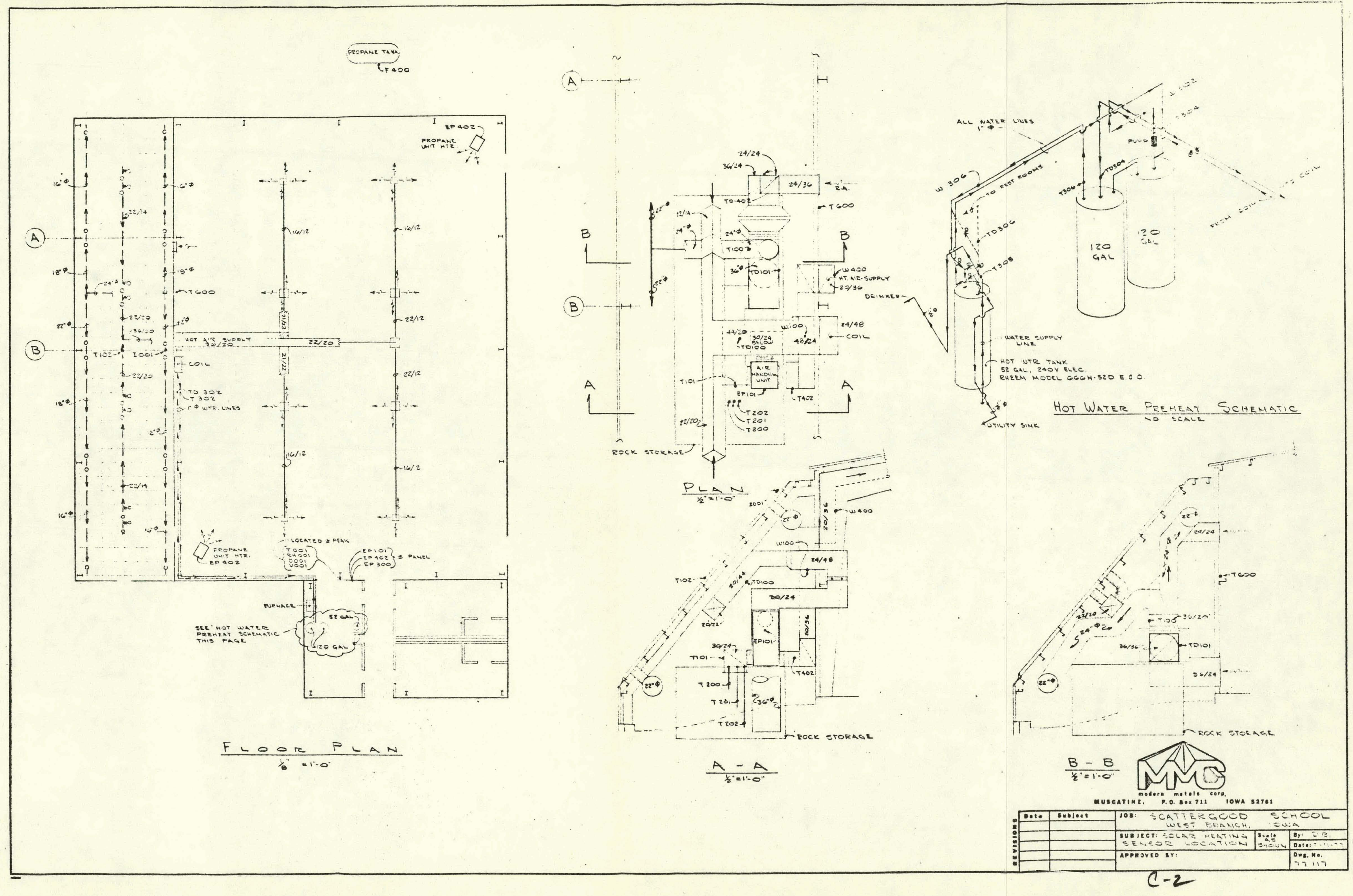


APPENDIX D

WIRING DIAGRAMS OF THE SOLAR HEATTIJG SYSTEM 


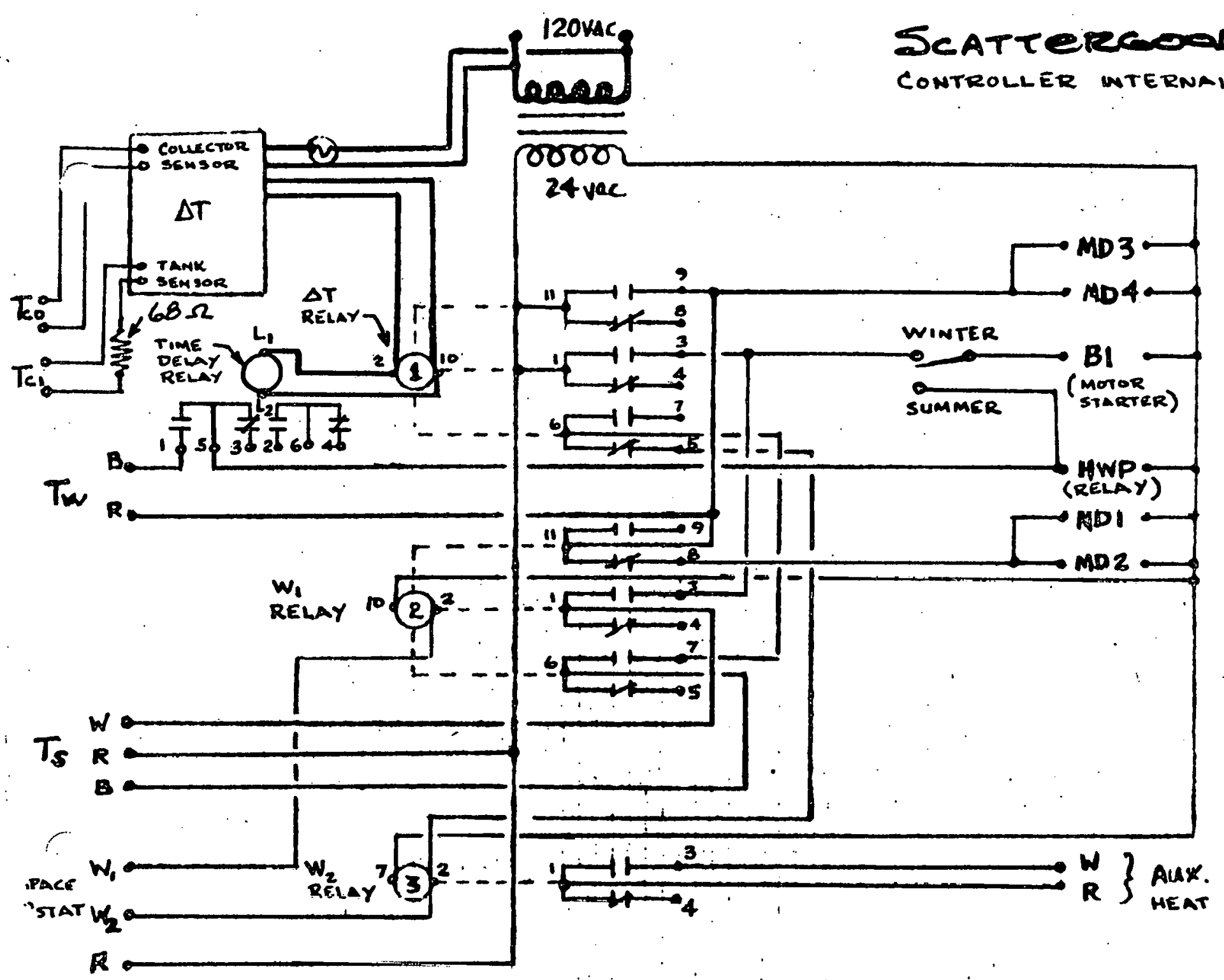

EQUIPMENT 'SCHEAULE

$\Delta T$ - Rat Reina Dix Cntrlo wo fuse.

Transf - $100 \mathrm{VA}$

$T_{S}$ - Honeywell T675A1540 Temp Contrls.

1 3PDT Saleid Relay Pligin Type

2 -. 3PDT sealad Relay alug in Type

3 - SPOT Sinkd Relay Prgin Type

THIS DRAWINS IS TII: D: TPERTY OF

SOLAROH $\cdots \cdots \cdots \cdot \cdots \cdot \quad \because Y M$ MAY

NOT RE: -

1ED IN

ANY WAY '. PLRMIS. 
APPENDIX E

SEQUENCE OF OPERATIONS OF THE SOLAR HEATING SYSTEM 
SCATTERGOOD SCHOOL

SEQUENCE OF OPERATION

WINTER OPERATION

Place "Summer-Winter" switch in "Winter" position and set time delay relay at three minutes. When there is a 45 degree $F$ temperature differential between the collector outlet temperature $\left(T_{C O}\right)$ and the collector inlet temperature. $\left(T_{C i}\right)$ the $\Delta T$ relay is energized (cut-out differential 30 degrees F). This closes the damper (MD-4) from the heat storage to the inlet of the air handling unit and opens the damper (MD-3) from the collectors to the AHU inlet. The damper (MD-1) from the discharge of the AHU to the heat storage opens and the damper (MD-2) from the AHU discharge to the heated space closes. Simultaneously, the AHU fan starts and if the water in the storage tank is below the set-point (140 degrees $F$, adjustable) of the temperature controller $\left(T_{W}\right)$ the circulating pump will run after the time delay cycle. When the space thermostat calls for heat at this time, MD-1 closes and MD-2 opens to direct the solar heated air through the building space: When the $\Delta \mathrm{T}$.relay is de-energized (no solar heat available from collectors) and the space thermostat calls for heat the AHU fan will run and use the heat from storage if the storage temperature is above 90 degrees $F$ (the set-point [adjustable] of $T_{S}$ ). In the event that the storage temperature is above 90 degrees $F$ and the air from storage is not enough to off-set the building heat loss the second stage heating circuit in the thermostat will make when the space temperature drops approximately $1-1 / 2$ degrees $F$ below the set point of the first stage. This will stop the AHU and bring on the auxiliary heat (unit heaters).: If the storage temperature is below 90 degrees $F$ the AHU will remain off and the auxiliary heating system will be automatically controlled by the first stage heating circuit. During "Winter" operation. manual dampers $D-1$ and D-3 shall be closed and D-2 open. 
SCATTERGOOD SCHOOL

SEQUENCE OF OPERATION

2.

\section{SUMMER OPERATION}

Place "Summer-Winter" switch in "Summer" position and set time delay relay at twenty minutes. The system shall be energized by differential control as in "Winter" operation. The heat storage box is bypassed by removing $0-3$ and installing $0-2$ with $0-1$ left closcd. The motorized dalmpers will operate as if storing heat as described above dnd the fan and pump will run after the time delay cycle is completed. The system will shut down when the water in the storage tank reaches the set point of $T_{W}$. If the insolation is relatively low the system will shut down on the differential control before $T_{W}$ is satisfied. The time delay rélay will prevent short-cycling. Manual damper $D-1$ can be opened to vent the collectors and the system power shut off if there is no need for hot water preheating in the summer. 
APPENDIX F

MAINTEENANCE INSTRUCTIONS FOR THE SOLAR HEATING SYSTEM 


\section{MAINTENANCE INSTRUCTIONS}

The following items should be performed semi-annually:

1. Inspect $V$-belt and sheaves for wear, check belt tension.

2. Inspect damper linkage.

3. Clean or replace filters (more frequent if required)

4. 0il pump motor with \#20 non-detergent oil - do not over lubricate.

5. 0il AHU blower motor with \#20 non-detergent oil - do not over lubricate

The following is to be done on annual basis:

1. Damper motors - lubricate the felt pads located on each of the motor bearings and on the two shafts in the gear train with \#10 non-detergent oil. 
APPENDIX G

SUBCONTRACTORS ASSOCIATED WITH THE SOLAR HEATING SYSTEM 
SUBCONTRACTORS ASSICIATED WITH THE CONSTRUCTION OF THE SOLAR HEATING SYSTEM

1. Solar

2. General

3. Structural Erection

5. Concrete

6. Electrical

7. Sensor Installation
Solaron, Inc. 300 Galleria Tower 720 South Colorado Boulevard Denver, Colorado 80222.

Modem Metals, Inc. P.O. Box 711 Muscatine, Iowa 52761

Quality Builders

Route 4

Box 120

Muscatine, Iowa 52761

Franz Construction Cormpany

P.O. Box 209

Iowa City, Iowa 52240

$\mathrm{P}$ and $\mathrm{S}$ Electric

1029. Hershey Avenue

Muscatine, Iowa 52761

Titronics, Inc.

P.O. Box 2202

Iowa City, Iowa 52240 
APPENDIX $\mathrm{H}$

ACCEPTANCE TEST OF THE SOLAR HEATING SYSTEM 


\section{SCATTERGOOD SCHOOL ACCEPTANCE TEST PLAN}

A visual inspection shall be made to assure ducting functionally conforms to the plans. Manual dampers $D-1$ and $D-3$ shall be closed and $D-2$ open. Space thermostat heat anticipators shall be set with first stage at 0.10 amp and second stage at 0.10 amp. Set thermostat so there is no call for heat. "SumerWinter" switch on control panel shall be placed in the "Winter" position. System power shali be turned on. If solar energy is sufficient to activate the $\Delta T$ controller the AHU fan and water pump will start and run in the storing heat mode: (If solar energy is not available disconnect Tco lead to simulate). Static pressure and temperature shall be measured in the collector inlet and outlet ducts and at the heat storage inlet and outlet ducts. The collector $\Delta \mathrm{P}$ will be used to estimate the flow and the fan speed will be adjusted accordingly if required. Fan motor amperage shal1 be measured.

The space thermostat shall be set to make the first stage of heating. This will reposition the dampers shifting the soldr heated air into the building space." Static pressures, temperatures and amperage shall be measured in this mode.

Jumpering Tco terminals (or opening Tci) will simulate no solar energy available at the collector. The system will then go into the heat from storage mode. Static pressurcs, temperatures and amperage will be recorded. Adjusting the set point of Ts upward to the air temperature out of storage will simulate the storage temperature dropping to the normal set point of $90^{\circ} \mathrm{F}$. When Ts switches the solar AHU will stop and the unit heaters will start and maintain the set point of the first stage of the thermostat. Ts shall then be reset down to place syster back in the heating from sturage mode. Increasing the set point of the space 
space thermostat to make the second stage of heating simulates a further drop in space temperature indicating the heat taken from storage is insufficient to offset the building heat loss. This will shut down the solar AHU and start the unit heaters. Jumper shall be removed from Tco.

"Summer" operation for preheating water shall be tested by removing manual damper $D-3$ and installing $D-2$ to by-pass the heat storage unit and placing the "Summer-Winter" switch in the "Summer" position. Static pressures, air temperatures and amperage shall be recorded. The aquastat. Tw; shall be reset down so that the set point is below the water temperature (if water temperature is below the minimum set point a lead can be disconnected). This will simulate the water temperature rising to the set point and will stop the pump and AHU fan. 
V. ACCEPTANCE TEST PIAN DATA SHEET FOR SCATIERGOOD SCHOOL

I. Visual Enspection
A. Ductwork configuration OK
B. P]acement of danpers OK
C. Other $\mathrm{OK}$

II. Winter--storing heat mode

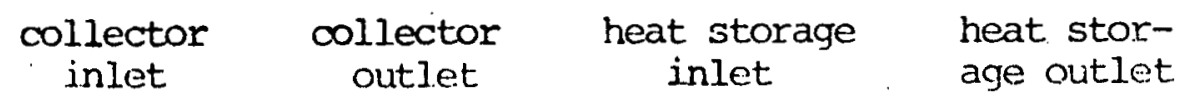

Static pressure

$$
\begin{aligned}
& -0.12 \text { " W.C. }-0.40^{\prime \prime}+0.38^{\prime \prime} \text { W.C. +0.01" } \\
& \Delta \mathrm{P}=0.37^{\prime \prime} \mathrm{W} . \mathrm{C} \text {. }
\end{aligned}
$$

Temperature

Calculated air flow

Air flow was measured in store-heat-from(showing calculations)

collector mode, Air flow in other modes

was calculated from data obtained in this mode. See attached sheets.

Fan motor amperage

12.6 amps

Synchronous operation of $\mathrm{AHO}$ and water purmp?

rII. Winter--heating from collector mode

Static pressure

$$
\begin{array}{cl}
\text { collector } & \text { collector } \\
\text { inlet } & \text { outlet }
\end{array}
$$

$-0.20^{\prime \prime}$ W.C. $-0.52^{\prime \prime}$ W.C.

Temperature

$\Delta \mathrm{P}=0.30^{\prime \prime} \mathrm{W} . \mathrm{C}$.

Calculated air flow $\quad 4870 \mathrm{cfm}$

Fan Motor angerage $\quad 12.5$ amps

Synchronous operation of

AHU and water pump?

$$
\text { yes }
$$

IV. Winter-heating from storage mode

Static pressure

$$
\begin{array}{lc}
\begin{array}{c}
\text { heat storage } \\
\text { inlet }
\end{array} & \begin{array}{c}
\text { heat storage } \\
\text { outlet }
\end{array} \\
-0.13^{\prime \prime} \text { W.C. } & -0.68^{\prime \prime} \text { W.C. } \\
\Delta P=.55^{\prime \prime} \text { W.C. }
\end{array}
$$

Temperature 
ACCEPTANCE TEST PLAN DATA SHEET (Cont.)

IV. Winter--heating from storage mode (cont.)

$$
\begin{gathered}
\text { heat storage heat storage } \\
\text { inlet }
\end{gathered}
$$

Calculated air flow

5500 cfm

Fan motor amerage

\section{1 amps}

Water pump off when AHU on? yes

V. Summer mode

$$
\begin{array}{cc}
\text { collector } & \text { collector } \\
\text { inlet } & \text { outlet }
\end{array}
$$

Static pressure

$$
-0.06^{\prime \prime} \text { W.C. }-0.37^{\prime \prime} \cdot \text { W.C. }
$$

Temperature

$$
\Delta P=0.31^{\prime \prime}
$$

Calculated air flow. $4780 \mathrm{cfm}$

Fan Motor amerage

\section{4 amps}

Synchronous operation of AHU and water pump?

AHU and pump on when aquastat setting above water temperature?

AHU and pump off when aquastat setting below water temperature?

VI. Unit heater operation mode

lieaters on when Ts raised to air temperature gut of storage? Wiring to unit heaters not mompleted. Control circuits functioning properiy. Healers on whin building thremostat raised?

Water pump and AHU off when heaters on? yes

VII. Miscellaneous observations A time delay relay has been provided to prevent the system from short-cycling in summer water heating mode. The sequence of operation and wiring diagram have been revised to show this.

VIII. Statement of acceptability of system

See attacbed copies of "itens to be corrected" dated 20 May and 14 June, 1977.

$$
\mathrm{H}-4
$$


SCATTERGOOD SCHOOL

EQUIPMENT DATA

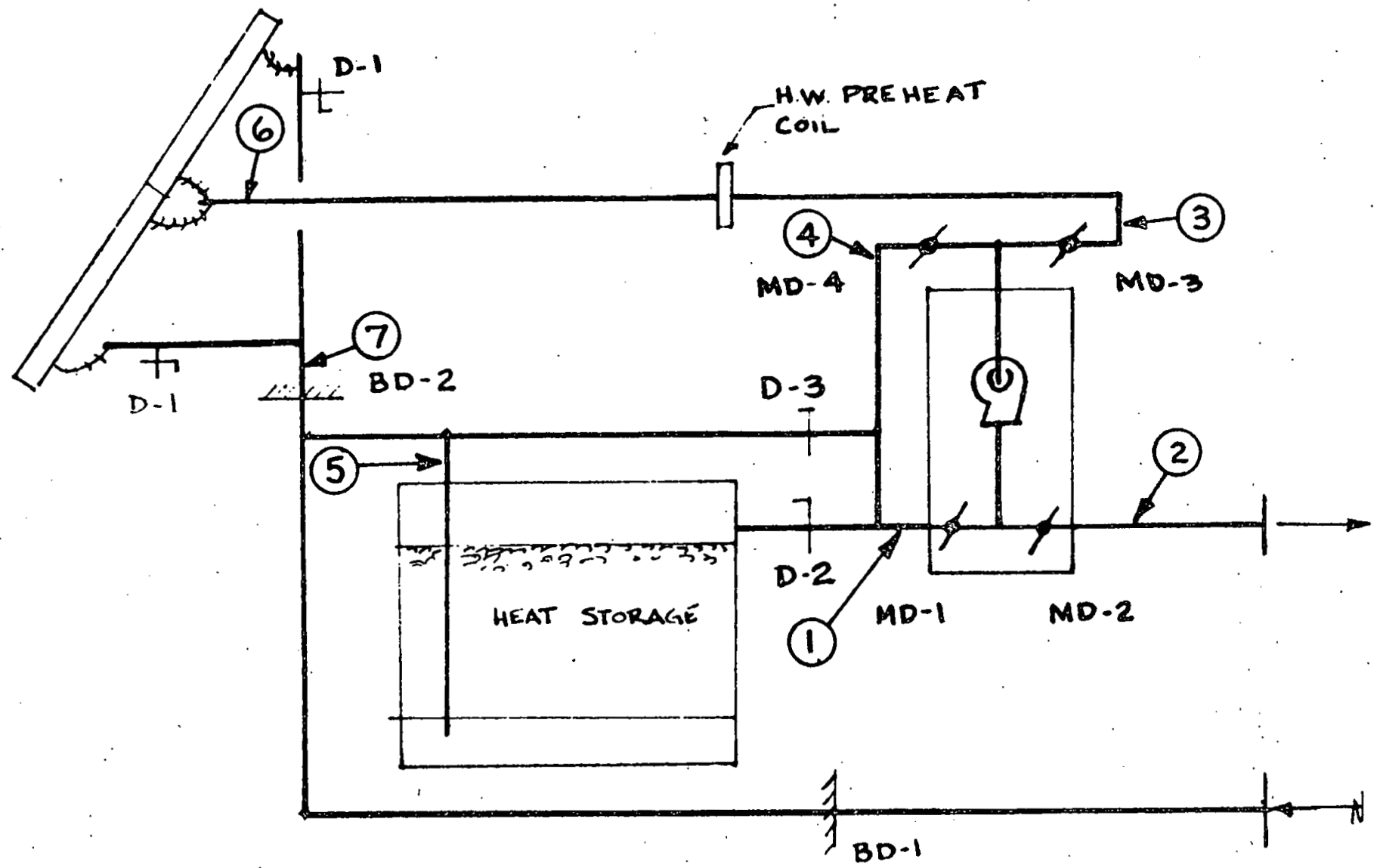

AHU MOTOR DATA: MAKE: DAYTON MODEL 5 K9676G FRAME LI84T: HP 3 VOLTAGE $115 / 200-230$ AMPS $30 / 15.7$ PHASE 1 SERVICE FACT. 1.0 RPM 1740 SHEAVE ZVP $56 \times 1 \frac{1}{8} "$

FAN DATA: MAKE: DAYTON MODEL 3CO48

RPM 1410 SHEAVE $2 B K .70 \mathrm{H}, \mathrm{H} \times 1 \%$. BELTS $2.4 L 51$

MOTOR AMPERES AND STATIC PRESSUIRE ("W.C.) FOR VARIOUS MODES

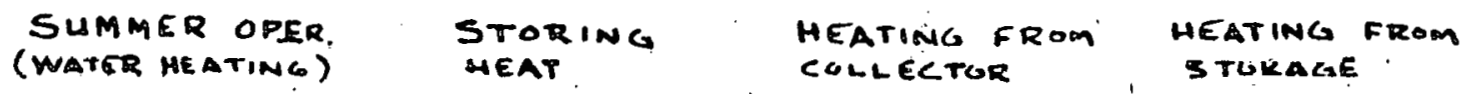
AMPS
12.4
12.6
12.5
14.1

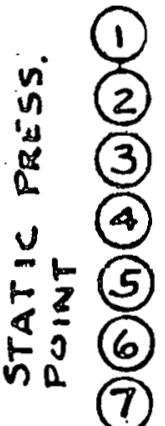
$+.15 "$
$+38^{\circ}$
$-.09^{\circ}$
$-.68^{\circ}$.
$-.01 "$
$-.02^{\circ}$
$+.38^{\circ}$
$+.40^{\circ}$
$-.63^{\circ}$
$-.65^{\prime \prime}$
$-.76^{\circ}$
$-.06$
$+.17^{\prime \prime}$
$+.49^{\circ}$
$-.08 "$
-.85"
$+.15^{\prime \prime}$
$+.01 "$
$-.09 "$
- .13."
$-.37^{\prime \prime}$
$-.40 "$
$-.52^{\prime \prime}$
$-.06^{\prime \prime}$
$-.06^{\prime \prime}$
$-.12^{\prime \prime}$
$-.20^{\prime \prime}$
$-.06^{\prime \prime}$ 


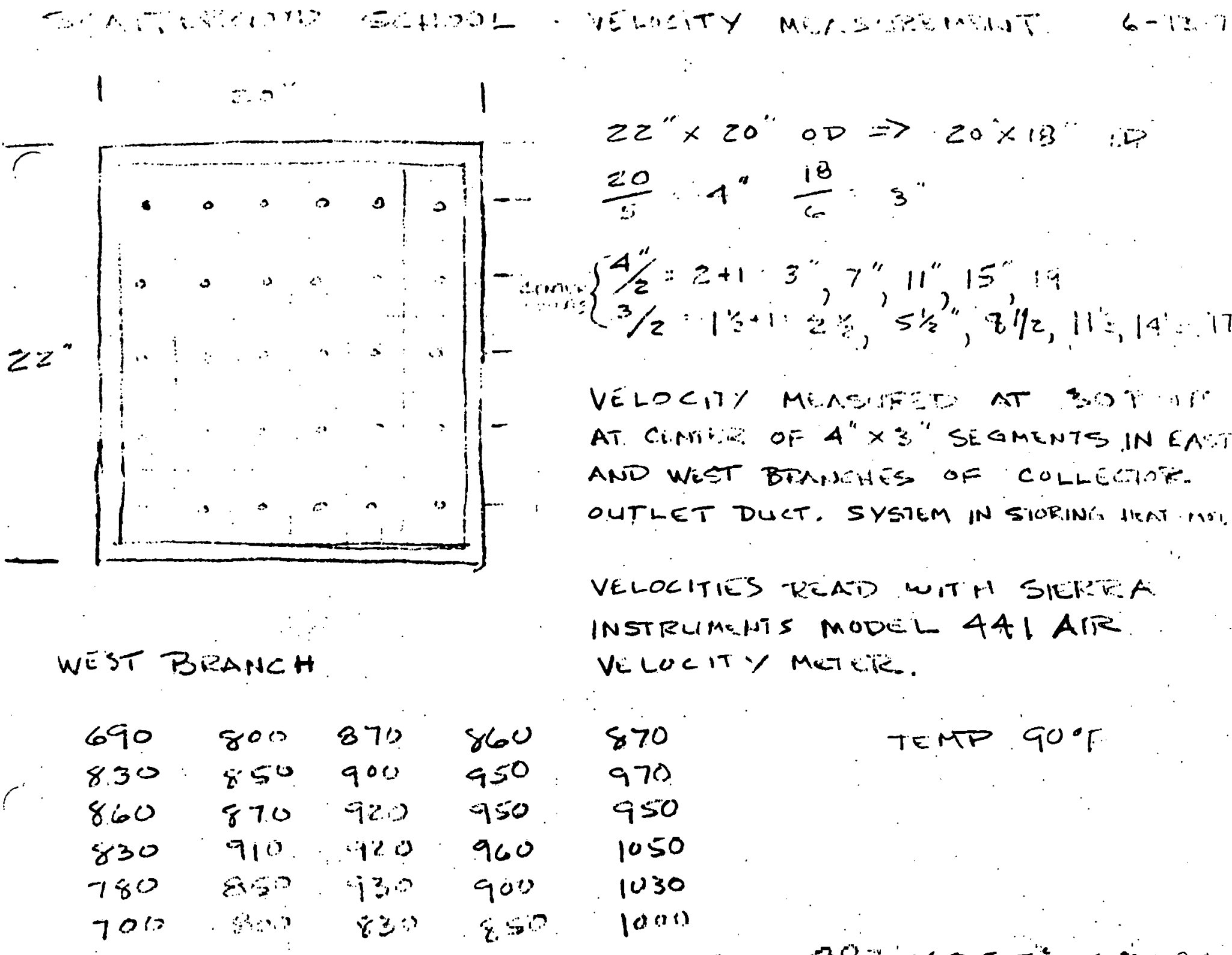

AVG FFM : $88 \div \times 2.5 T^{\circ}=26084$

EAST TSRANCH

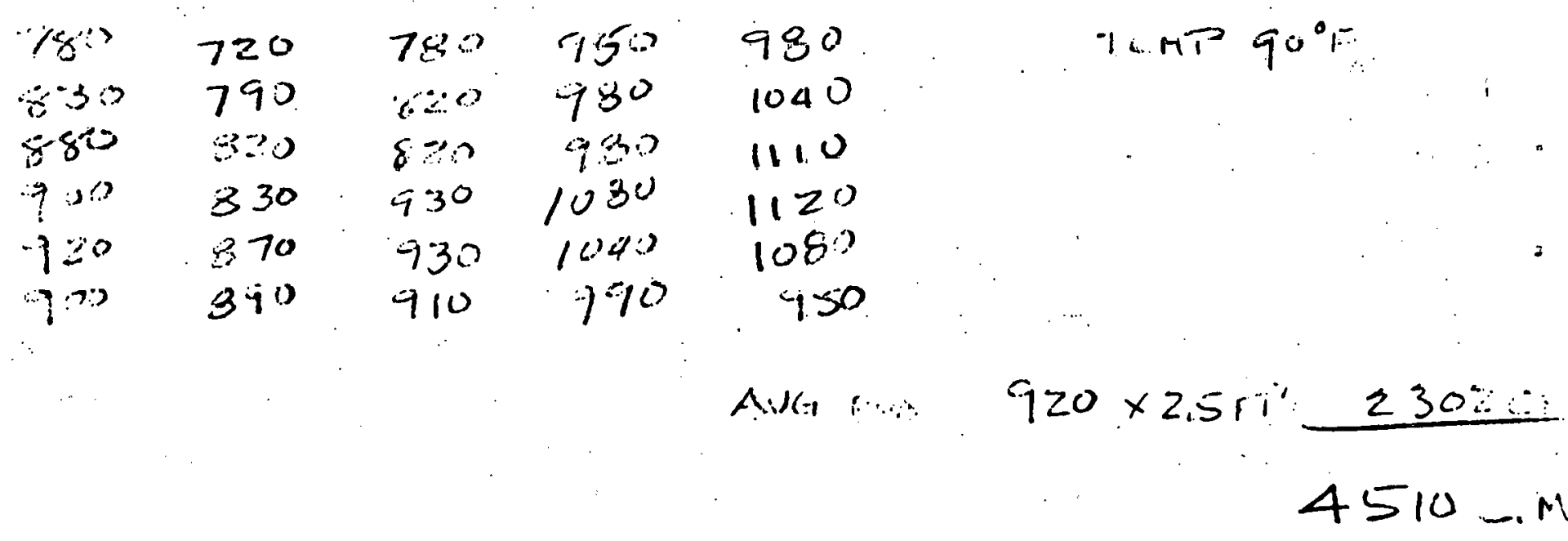

$H-6$ 
AIR flow calculations

MEASURED AIR FLOW IN STORING HEAT MODE 4510 CF COLLECTOR $\triangle P=0.28 \%$ wC. , STORAGE $\triangle P=0.37 \%$ w.C.

USING THE FOLLOWING RELATIONSHIPS OF. FLOW RATES ANT STATIC PRESSURE DROPS THE FLOW RATES FOR OTHER MODES ARE obTAINED:

COLLECTORS:

$$
\frac{\Delta P_{2}}{\Delta P_{1}}=\left(\frac{C F M_{2}}{C F M_{1}}\right)^{1.75}
$$

storage

$$
\frac{\Delta P_{2}}{\Delta P_{i}}=\left(\frac{C F M_{2}}{C F M_{1}}\right)^{2}
$$

HEATING FROM STORAGE:

$$
\begin{aligned}
& \frac{.37^{\circ}}{.55}=\left(\frac{4510}{C F M}\right)^{2} \\
& \sqrt{.6727}=\frac{4510}{C F M} \\
& 82 \text { CF }=4510 \\
& \text { CF }=5500
\end{aligned}
$$

HEATING FROM COLLECTOR:

$$
\begin{aligned}
& \frac{.28}{.32}=\left(\frac{4510}{\text { CFO }}\right)^{1.75} \\
& \sqrt[1.75]{.875}=\frac{4510}{\text { CF }} \\
& .9265 \text { CFO }=4510 \\
& \text { CFO }=48.70
\end{aligned}
$$

SUMMER WATER HEATING:

$$
\begin{aligned}
& \frac{.28}{.31}=\left(\frac{4510}{C F M}\right)^{1.75} \\
& \sqrt[1.75]{.9032}=\frac{4510}{C F M} \\
& .9435 \text { CF }=4510 \\
& \text { CF }=4780
\end{aligned}
$$

Hi 


\section{LETTER OF TRANSMITTAL}

Ta: CaAlPAI? UW:NS
Dato:Zn MAX 187Z:

Pago: of

.

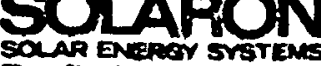
Profit from the sun

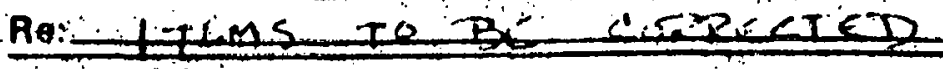

Forwarded Herewith: $\square$ Technical Data : Plans $\square$ Specifications $\square$ Other

Purpose: $\square$ For Your Info. D. As Requested D For Rovilow \& Comment D fór Your Action

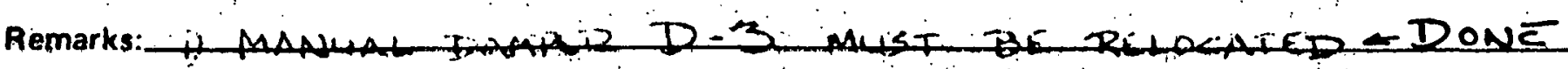

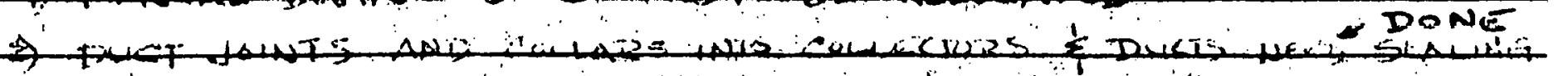

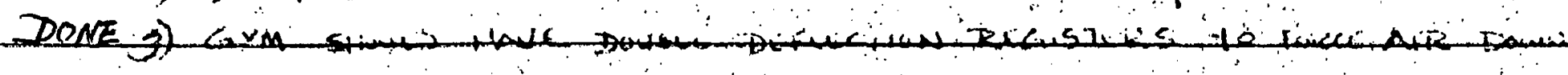

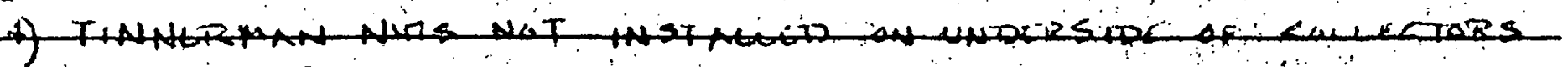

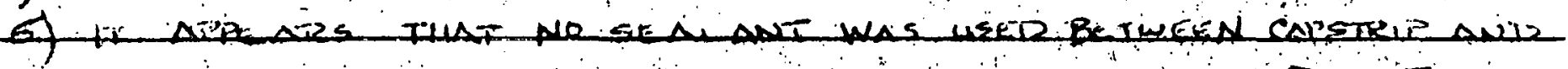

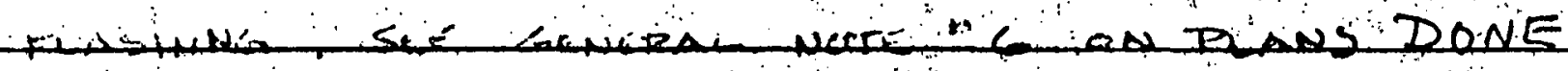

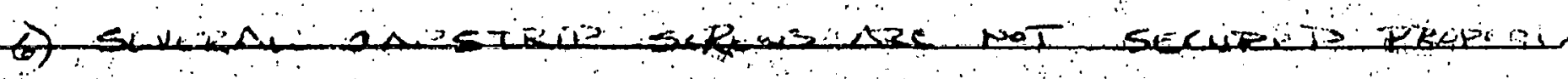

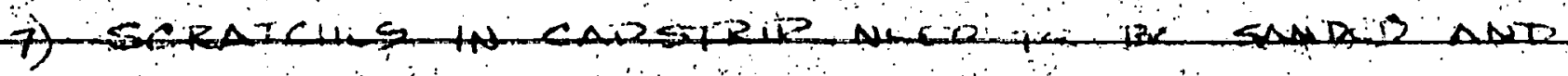

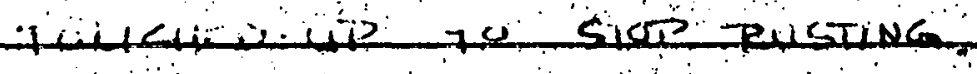

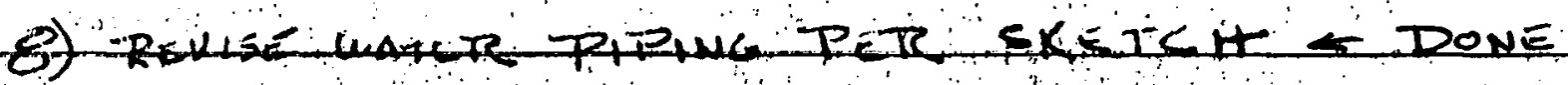

Copy to:

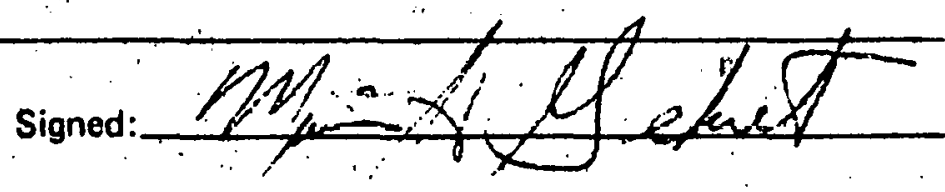




\section{LETTER OF TRANSMITTAL}

To: CONATO HENS
Date: $6-14-77$

Paga: of

Proj. No.

Forwarded Herewith: $\square$ Technical Data $\square$ Plans: $\square$ Specifications $\square$ Other

Purpose: $\square$ For Your Info.: $\square$ As Requested $\square$ For Roview \& Comment $\square$ For Your Action

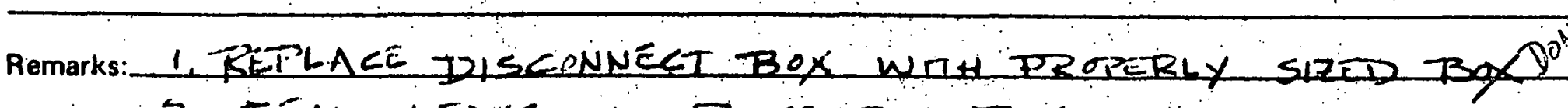
2. SEAL LEAKS IN TUP OF ROLK BOX. 3 SFAL LEAK ARUNDD DAMPER SHAFIS DONE 4 " LAP IN DUCT DOWNSTREAM OEFH DOSDONE 5. COMPLETE ITEMS ON UST DATED zi MAY 1977 7. CONPLETE CONTROL WIRING COMNECTION TO 4 NITH H 7. CONPLETE CONTROL WIRING COMNECTION TO 4 N, HEATERS

Copy to:

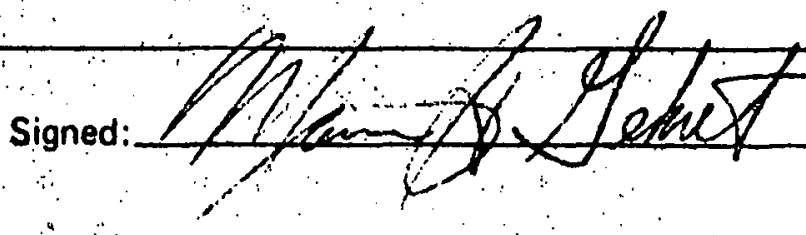


APPENDIX I

REPORT ON GRATN DRYING MODIFICATION TO SCAITERGOOD SCHOOL SOLAR HEATING SYSTEM 
REPORT ON THE GRAIN DRXING MODIFICATIONS TO THE SCATTERGOOD SCHOOL SOLAR HEATING SYSTEM

Introduction

In the summer of 1977 , Scattergood School was invited to participate in a research project on solar grain drying directed by Dr. $C_{a} r l$ Bern, a professor in the Department of Agricultural Engineering at Iowa State University. The project would involve adapting the recently completed solar heating system, built as part of the National Solar Heating and Cooling Demonstration Program and used to heat the school's gymnasium, so that hot air from the collector could be directed into a 6,000-bushel grain drying silo. Air temperatures and the moisture content of the grain, in this case, corn, would be monitored. The necessary changes to the existing system would be relatively minor and would not affect its primary operation.

Industry was interested in the experiment. The Butler Manufacturing Company, a leading manufacturer of grain storage and drying apparatus, was willing to fumish the school a new, 6,000-bushel Stir-Ator grain-drying silo at a considerable reduction in cost. Scattergood felt the opportunity was attractive, and requested permission of their Contracting Officer's Representative ( $C O R$ ) to make the required modifications. The COR supported the school's request, and permission was granted under the following conditions.

1. The grain drying system be operated only when the gymnasium and the rock storage system do not requtre heat.

2. Ambient air rather than air from the gymasium comprise the cold air intake during grain drying operations. 
3. Three government-furnished sensors to monitor inlet temperature, outlet temperature and volume of air flow during grain drying operations be installed in the new ductwork and connected to the existing Site Data Acgisition Subsystem.

4. The grain drying project have no cost impact on the main project.

The school agreed to these conditions, and the grain drying syatem was constructed during October, 1977.

\section{Description of the System}

The grain drying system consists of a 6,000-bushel Butler Stir-Ator ${ }^{2 M}$ grain drying silo equipped with an air heater and an air handling unit. Air is drawn into the bottom of the silo by a $5 \mathrm{hp}$ fan with a capacity of about 8,000 cfm. A propane heater, positioned immediately after the fan, provides additional heat when needed. Air from the solar collector enters a short distance from the fan intake. The 5-inch gap between the end of the solar ductwork and the fan housing permits addtional, ambient air to be introduced. The silo is located about 35 feet of the gymnasium.

The following modifications were made to the existing solar heating aystem.

1. A 2-ft diameter duct was connected to the hot air ductwork leading to the gymnasium at the place where the duct makes a $90^{\circ}$ bend from horizontal to vertical and ascends $t$ ? enter the gymnasium. Two new slide-gate dampers were introm duced, one in the new duct slose to the point of attachments and the other in the gymnasium duct about one foot above the crisor. 
2. The new hot air duct was extended through the west wall of the "A-frame" (the enclosure formed by the collector and the south wall of the gymnasium) and further extended to the grain drying silo. The duct was wrapped with fiberglass insulation for its entire length and, where outside, wrapped with a double layer of 6-mil polyethylene film.

3. A 2-ft diameter air return duct was connected to the existing ductwork where the top and bottom cold air return ducts coming from the gymnasium join. Three additional side-gate dampers were introduced--one in the new duct close to the point of attachment and the other two in the upper and lower gymnasium air return ducts near where they join.

4. The new air return duct was extended through the west vall of the A-frame and projects out about 4 inches. It is positioned directly below the hot air duct.

The opening in the west wall of the A-frame around the ducts was closed with a piece of exterior siding; small cracks were. sealed with fiberglass. Covers for both ducts were made. they are in place whenever the grain drying system is not in operation. A schematic diagram of the system, with alterations. marked in red, is shown on the next page. 


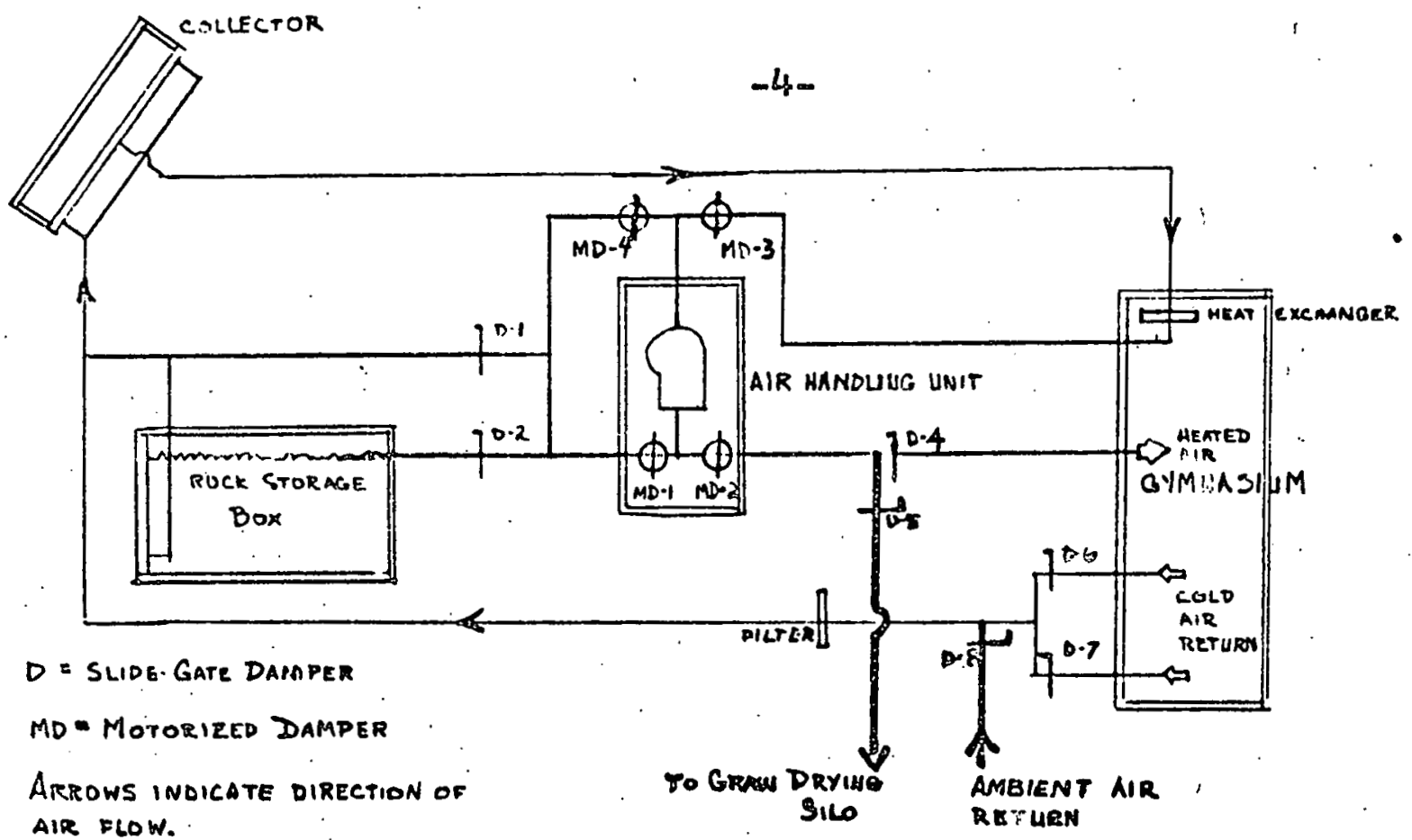

Figure 1. Schematic Diagram of the Altcred Solar Heating System Operation of the Crain Drying System in 1977

The solar grain dryer saw only limited used during 1977. Tabulated below are the times the system was in operation. Date Fan on Fan of t Time in Use (hr)

\begin{tabular}{|c|c|c|c|c|c|c|}
\hline October & 28 & $1: 50^{\circ} \mathrm{pm}$ & $2: 40$ & $\mathrm{pm}$ & & 0.83 \\
\hline November & 22 & $21: 45$ am & $22: 50$ & $"$ & & 1.08 \\
\hline$"$ & 13 & $1: 00 \mathrm{pm}$ & $4: 30$ & " & & 3.50 \\
\hline$"$ & 24 & $20: 00 \mathrm{~mm}$ & $5: 10$ & "i & $\frown$ & 7.17 \\
\hline in & 27 & $22: 45 \mathrm{pm}$ & $5: 00$ & ii & & 5.25 \\
\hline i & 18 & $10: 30 \mathrm{am}$ & $4: 00$ & it & & 5.50 \\
\hline is & 21 & $1: 30 \mathrm{pm}$ & $2: 30$ & "1 & & 1.00 \\
\hline
\end{tabular}

The moisture content of the corn was reduced from about 19.2 to $18 \%$ during this time. No supplementary heat was used. On December 22 the corn was frozen by blowing through cold, anbient air. In this condition the grain should keep until 
Spring. At that time we plan to use the collector to complete the drying process, lowering the moisture content of the corn to about $14 \%$. We anticipate that by this date the flow and temperature sensors will be installed so that we can messure accurately the total solar energy used. 
APPENDIX J

PRODUCT LITERATURE FOR COMPONENTS OF THE SOLAR HEATING SYSTEM 
Because the information originally included on pages $\mathrm{J}-1, \mathrm{~J}-2, \mathrm{~J}-3$, and $J-4$ is copyrighted (1976), the se pages are deleted from this document. For Solar Collector information, contact the Solaron Corporation, 4850 Olive Street, Commerce City, Colorado, 80022, or phone 303/289-5971. The reference is to the Air Type Solar Collector, series 2000. 


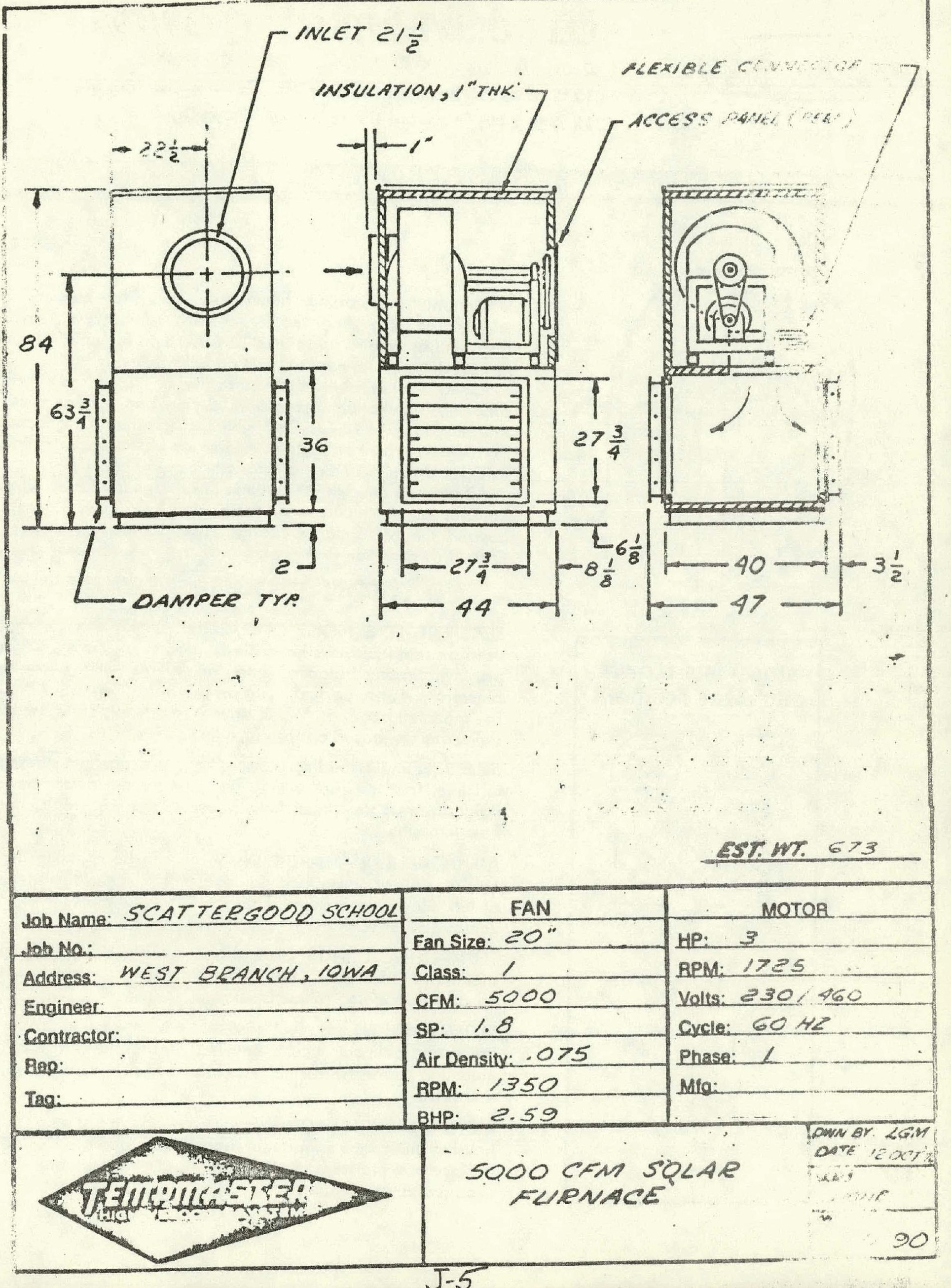




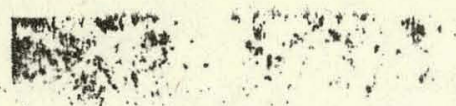

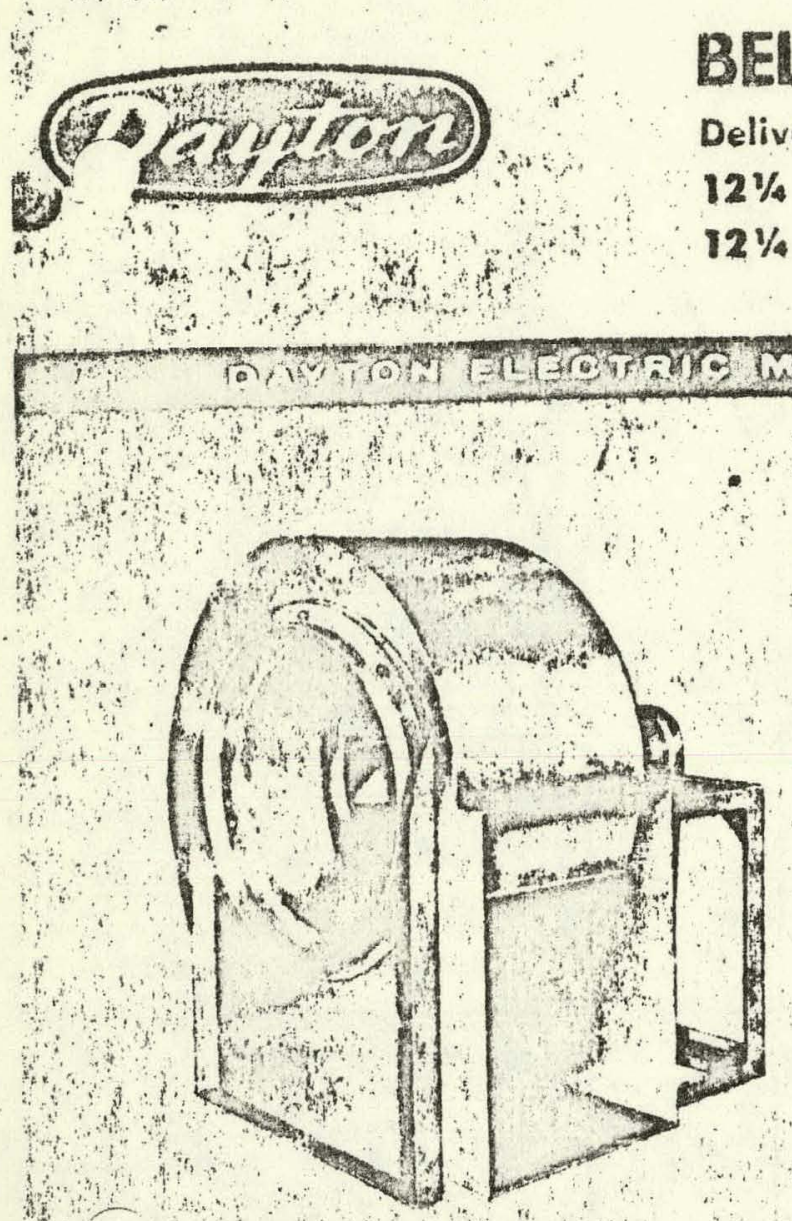

\section{ADJUSTABLE BLOWER DISCHARGE POSITIONS}

Deliver up to 26,000 CFM. AMiCA Class I Construction

$12 \%$ a $36 \%$ " Backward Incline Wheels, Non-Overloading

Dayton non-overlaading, heavy-duty, beli-drive hlowirs are 2 widely used for heating, ventilating, kitchen extiaust and similar in w systems that require up to 26,000 CFMi. Built for elficient, con tinuous duty. Performance charts on following peeges. is

Forward-eurve wheel blowers are widaly uded for air conditioning, ventilating, processing, dryirg and simita systems that require up to 12,420 CFM. Quiet, efficient, and ecorromical. Performance chart on page 4. All Dayton blowers are ovailable from local dealer and distributor stocks.

All blowers listed in this bulletin are designed to meet Class I construction specifications as designated by AMC A Operation beyond the perfarmance ratings given requires a blower of Class II construction or higher.

\section{DAYTON BLOWER FEATUTES}

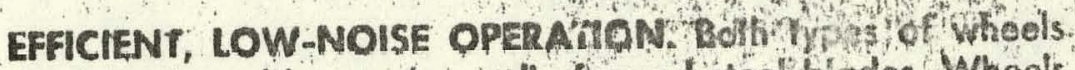
used on these blowers have die-formed stecl blades. Wheels are dynamically balanced and factory fested in csesembled blowers to assure perfect balance. Drive shaft ogerates in rubber mounted bearings. V-belt drive is practicolly soundless, Air deliveries are based on standard testicades of AMACA.

INLTS. Non-overloading blowers have a deopispun steel veaturi inlet that overlaps wheet. Forword-curve blawers kave a rigidly-formed steel inlet. Bath assure streantinet, efticient air flow into whael.

ADJUSTABLE DISCHARGE, Discharge can be changed in the field to any of seven optional directions showr th illustration at left. Blowers are shipped set for $\mathrm{CW}$ rotation, bottom horizontal discharge.

LONG-LIFE BEARINGS. Ground and polished dive shaft oper: ates in two self-aligning, pre-lubricated and sealed bqll berarings on rubber mounted pillow blocken

MOTOR MOUNT has pivot base that permis cary motdr installation and belt adjustment. Base has slolied holas bo fociliture mounting NEMA frame motors. Qlowers ora chpped less moton and drive.

RIGID CONSTRUCTION. Sturdy, heavy-gavgo arsewelded steal housing and frame with angle-braced sides cond drivs supports. Surfaces are pre-freated agoinst rust, and corrosion crd fiaished in baked-on gray enamel.

$$
J-6
$$




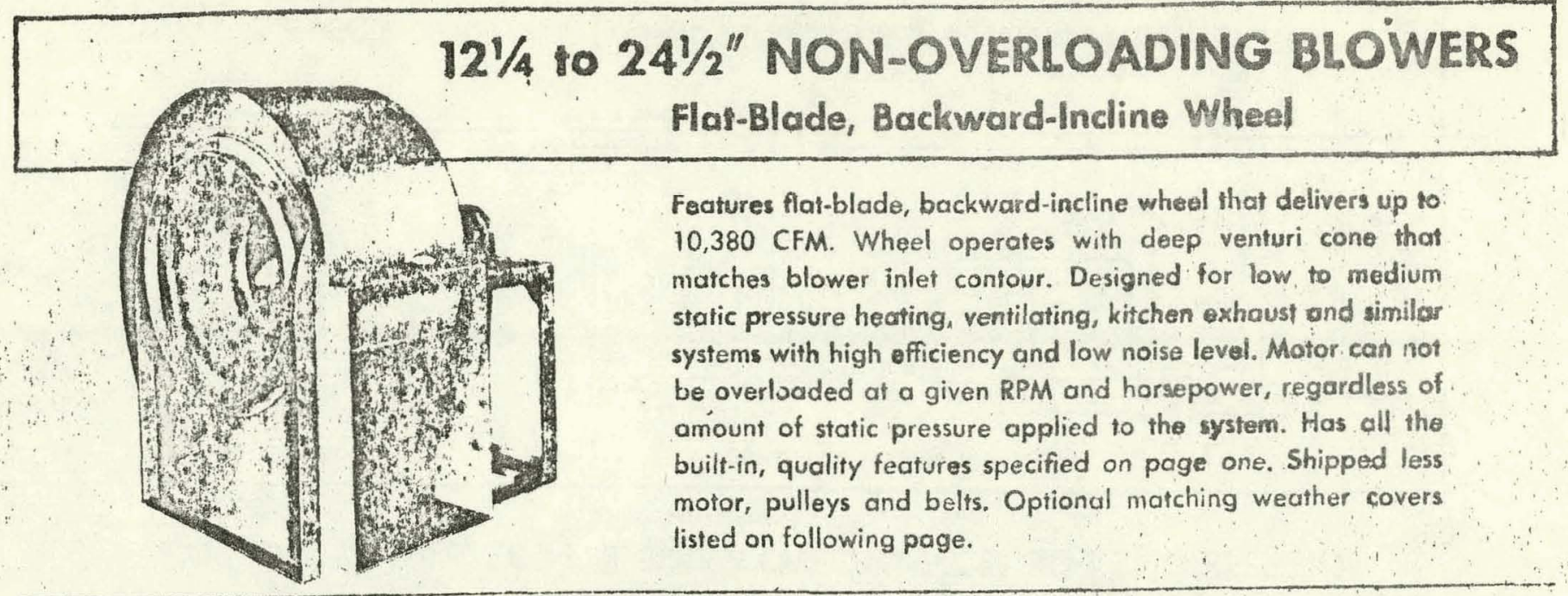

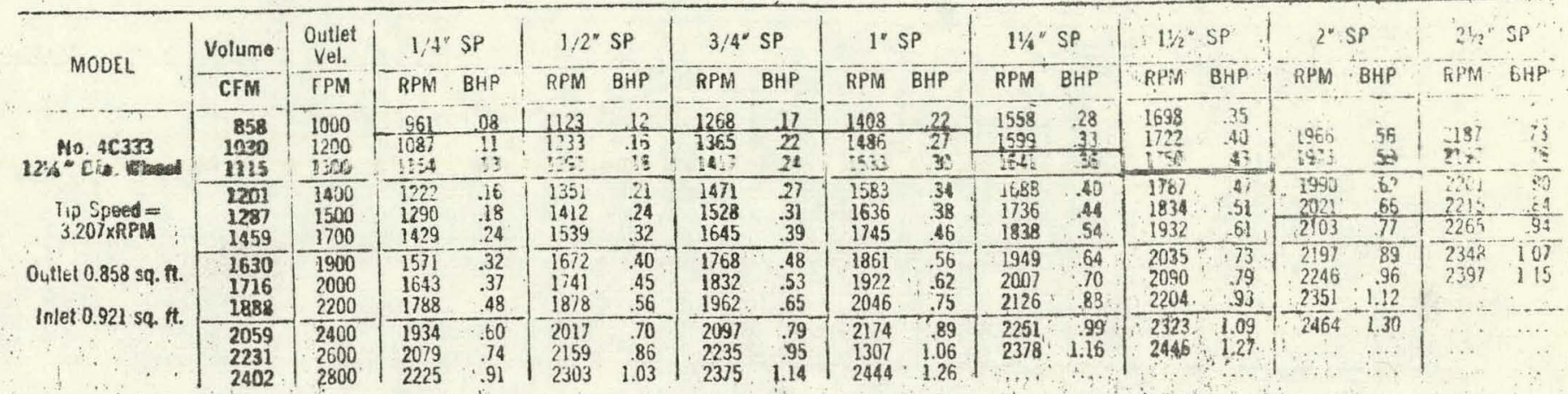

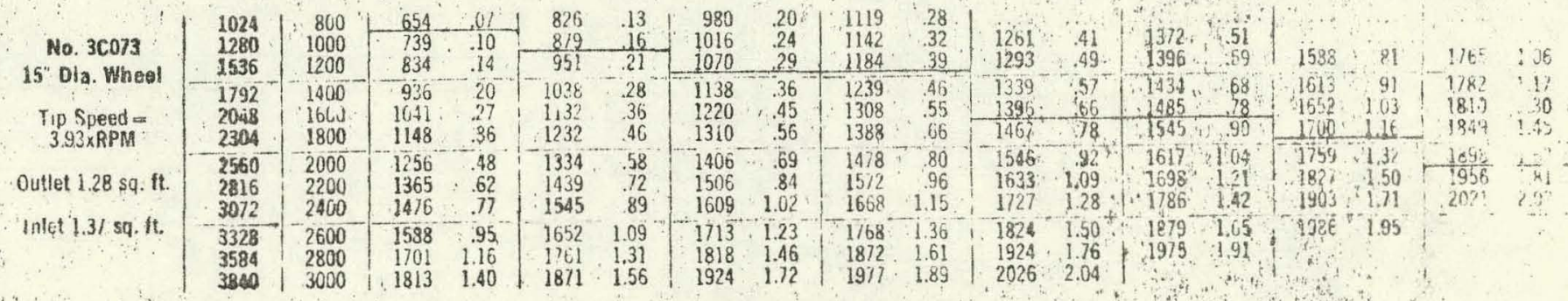

\begin{tabular}{|c|c|c|c|c|c|c|c|c|c|c|c|c|c|c|c|c|c|c|}
\hline 810.0 & $\begin{array}{l}1520 \\
1900 \\
2280\end{array}$ & $\begin{array}{l}800 \\
1000 \\
1200\end{array}$ & 691 & $\begin{array}{l}.15 \\
.22\end{array}$ & $\begin{array}{l}682 \\
7332 \\
792\end{array}$ & $\frac{.19}{.25}$ & $\begin{array}{r}808 \\
840 \\
889\end{array}$ & $\begin{array}{r}.29 \\
\frac{.35}{.44}\end{array}$ & $\begin{array}{l}926 \\
941 \\
980 \\
\end{array}$ & $\begin{array}{r}40 \\
47 \\
57 \\
\end{array}$ & $\begin{array}{l}1040 \\
1066\end{array}$ & $\begin{array}{l}61 \\
70\end{array}$ & $\begin{array}{l}1134 \\
1159\end{array}$ & 8.75 & $13 \angle 0$ & 1.18 & 1451 & \\
\hline $\begin{array}{l}\text { Tio Speed }= \\
4.78 \times \text { fin }\end{array}$ & $\begin{array}{l}2656 \\
3040 \\
3420\end{array}$ & $\begin{array}{l}1400 \\
1600 \\
1800\end{array}$ & $\begin{array}{l}774 \\
859 \\
945\end{array}$ & $\begin{array}{l}31 \\
42 \\
56\end{array}$ & $\begin{array}{r}862 \\
938 \\
1019\end{array}$ & $\begin{array}{l}43 \\
.55 \\
.70\end{array}$ & $\begin{array}{r}948 \\
1014 \\
1088\end{array}$ & $\begin{array}{l}.55 \\
.69 \\
.86\end{array}$ & $\begin{array}{l}1030 \\
1089 \\
1155\end{array}$ & $\begin{array}{l}.69 \\
84 \\
1.02\end{array}$ & $\begin{array}{l}1109 \\
1162 \\
1221\end{array}$ & $\begin{array}{r}83 \\
.99 \\
1.19\end{array}$ & $\begin{array}{l}1184 \\
1232 \\
1286\end{array}$ & $\begin{array}{l}98 \\
1.15 \\
1.36\end{array}$ & $\begin{array}{r}1329 \\
1365 \\
1410\end{array}$ & $\begin{array}{r}1.32 \\
1.50 \\
-1.13\end{array}$ & $\begin{array}{l}1469 \\
1491 \\
152\end{array}$ & $\begin{array}{l}1.13 \\
138 \\
2.11\end{array}$ \\
\hline Outlet 1.90 sq. ft. & $\begin{array}{l}3800 \\
4180 \\
4560\end{array}$ & $\begin{array}{l}2000 \\
2200 \\
2400\end{array}$ & $\begin{array}{l}1034 \\
1123 \\
1213\end{array}$ & $\begin{array}{r}.72 \\
.92 \\
1.16\end{array}$ & $\begin{array}{l}1102 \\
1187 \\
1274\end{array}$ & $\begin{array}{r}.89 \\
1.11 \\
1.36\end{array}$ & $\begin{array}{l}1165 \\
1246 \\
1330\end{array}$ & $\begin{array}{l}1.05 \\
1.28 \\
1.56\end{array}$ & $\begin{array}{l}1226 \\
1302 \\
1382\end{array}$ & $\begin{array}{l}1.23 \\
1.48 \\
1.76\end{array}$ & $\begin{array}{l}1287 \\
1358 \\
1432\end{array}$ & $\begin{array}{l}1.41 \\
1.67 \\
1.96\end{array}$ & $\begin{array}{l}1346 \\
1412 \\
1484\end{array}$ & $\begin{array}{l}1.59 \\
1.86 \\
2.17\end{array}$ & $\begin{array}{l}1962 \\
1521 \\
1585 \\
\end{array}$ & $\begin{array}{r}1.98 \\
2.28 \\
2.62 \\
\end{array}$ & $\begin{array}{l}1511 \\
1025\end{array}$ & 39 \\
\hline Inlet $2.02 \mathrm{sq} . \mathrm{ft}$ & $\begin{array}{l}4980 \\
5320 \\
57000\end{array}$ & $\begin{array}{l}2600 \\
2800 \\
3000\end{array}$ & $\begin{array}{l}1304 \\
1396 \\
1487\end{array}$ & $\begin{array}{l}1.44 \\
1.76 \\
2.12\end{array}$ & $\begin{array}{l}1361 \\
1449 \\
1538\end{array}$ & $\begin{array}{l}1.65 \\
1.99 \\
2.37\end{array}$ & $\begin{array}{l}1415 \\
1500 \\
1586\end{array}$ & $\begin{array}{l}1.87 \\
2.22 \\
2.62\end{array}$ & $\begin{array}{l}1464 \\
1547 \\
1631\end{array}$ & $\begin{array}{l}2.08 \\
2.45 \\
2.87\end{array}$ & 1510 & $\begin{array}{l}2.29 \\
2.68\end{array}$ & $\begin{array}{l}1559 \\
1636\end{array}$ & $\begin{array}{l}2.62 \\
2.92\end{array}$ & 1653 & 3.00 & & \\
\hline
\end{tabular}

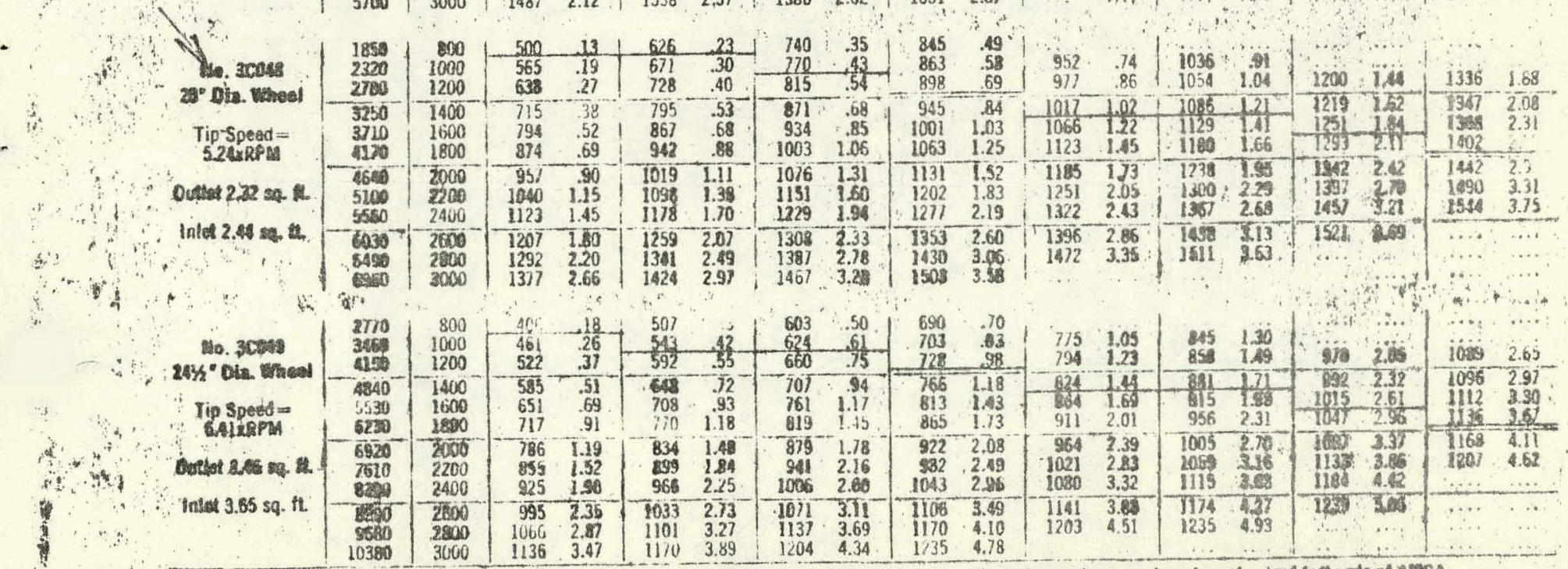




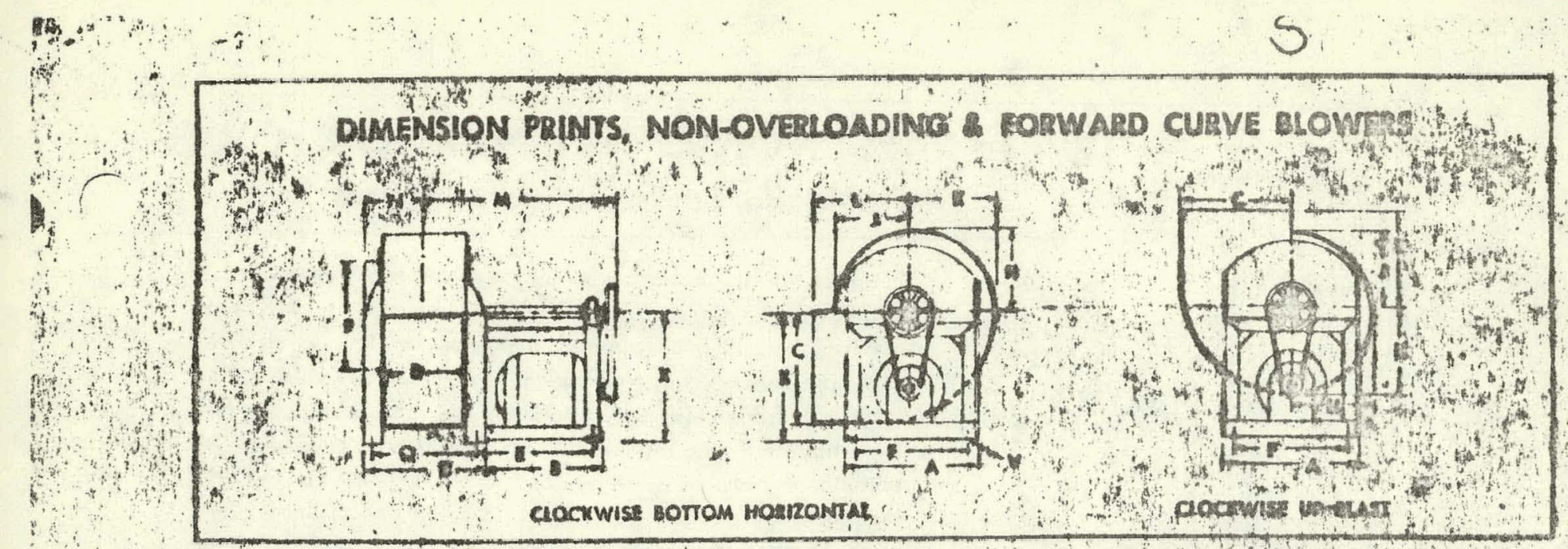

DIMENSIONS FOR NON-OVERLOADING \& FORWABO CURVE BLOUESS

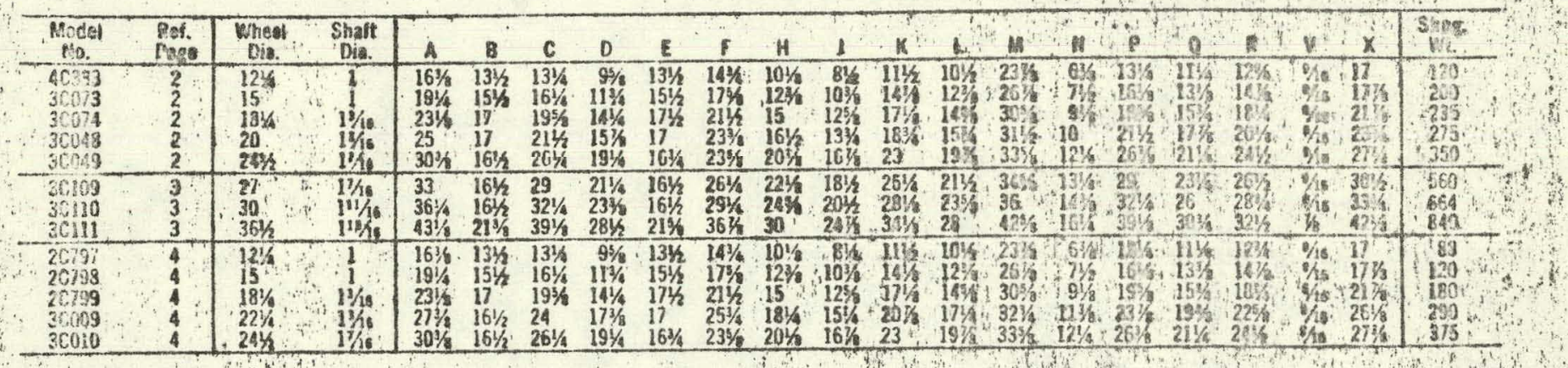

\section{OTHER DaMglota BLOWERS}

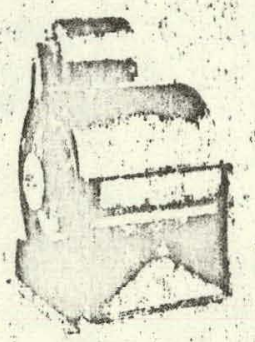

UNIVERSAL-MOUNT BLOWERS BELT \& DIRECT DRIVE

Request Bulletin 701

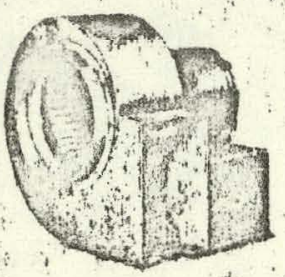

HIGH VOL. \& PRESSURE HOWEAS Reques tulletin 706 .
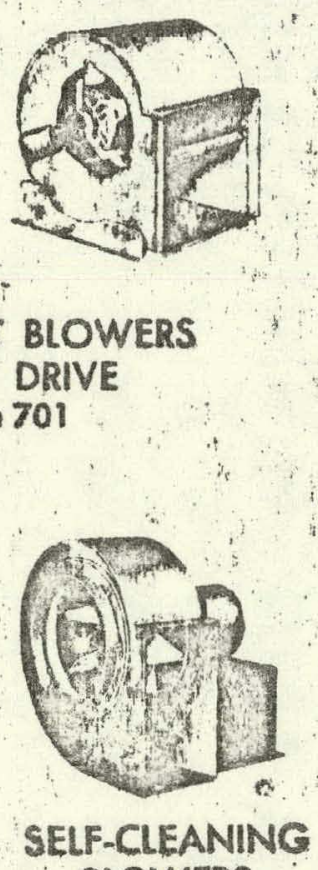
BLOWERS

Request Bulletin 708

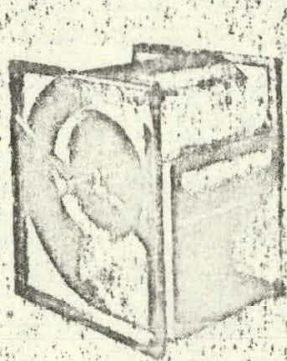

HIGH-CAPACITY RIOMERS

Request Bulletin zor 
Homeywell

M436 AND M836 ARE SPRING RETURN DAMPER MOTORS FOR RESIDENTIAL AND LIGHT COMMERCIAL APPLICATIONS IN SERIES 40 AND SERIES 80 CIRCUITS.

$\square$ Motors provide 2-position zone control.

$\square$ Used to operate outdoor air dampers for combustion or makeup air, changeover dampers for heating and cooling systems, minimum position dampers for ventilation and similar applications.

$\square$ Damper motors have an internal spdt switch for controlling auxiliary equipment, additional motors, or to provide a burner interlock switch.

口M436 models require 120 or $240 \mathrm{~V}, 60 \mathrm{~Hz}$ supply; M836 models are for $24 \mathrm{~V}, 60 \mathrm{~Hz}$ supply.

$\square$ Case and cover on all models.

- Spring returns the motor to the start position in case of power interruption or failure.

$\square$ Hexagonal output shafts on both ends of the motor with rotational direction stamped on the motor case.

D M436A and M836A are equipped with a thermal breaker for overload protection during the lifting stroke or if the motor becomes stalled.

口 M836A with bracket, Part No. 128499 , directly replaces the M87A Damper Motor.

H.A.

REV.10-75(.025)

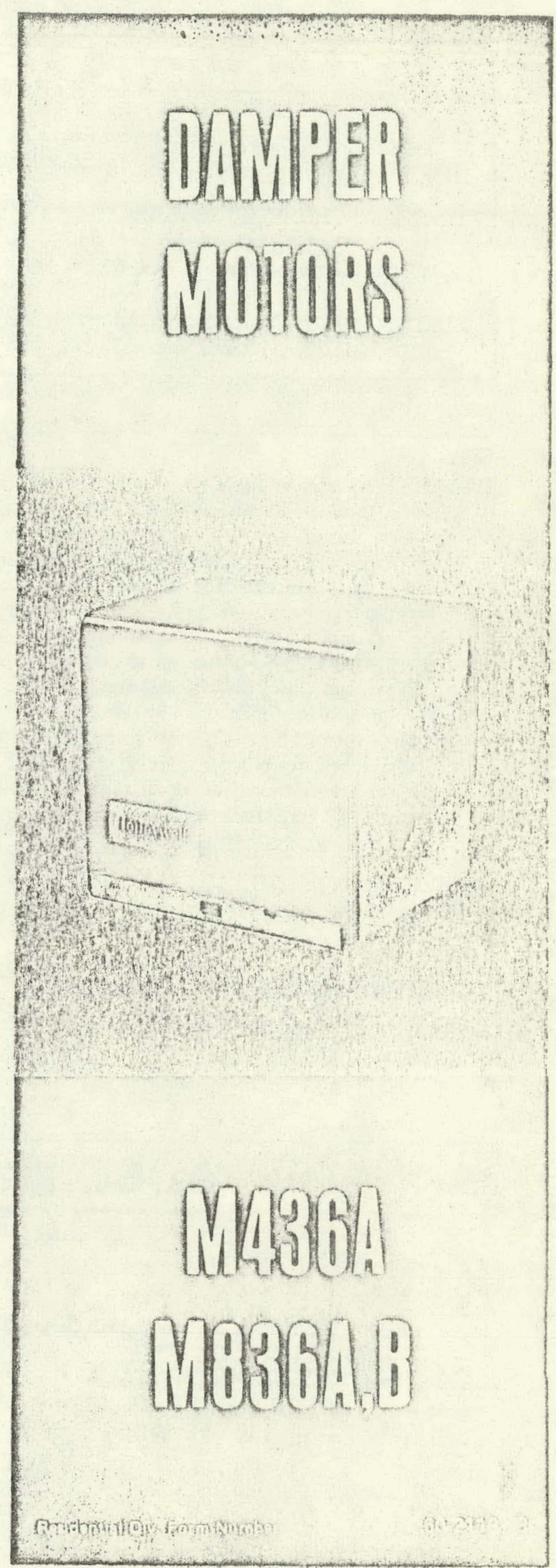




\section{SPECIFICATIONS}

\section{TRADELINE MODELS}

Tradeline models are selected and packaged to provide ease of stocking, ease of handling, and maximum replacement value. Tradeline model specifications are the same as those of standard models except as noted below.

TRADELINE MODELS AVAILABLE:

M436A Damper Motor-120 or 240V, $60 \mathrm{~Hz}$. M836A, B Damper Motors-24V, $60 \mathrm{~Hz}$.

ACCESSORIES INCLUDED: Mounting brackets, Part Nos. 126809, 128336, and 128499, and bag assembly containing the drive bushings, adapter, and coupling necessary for direct drive applications and the crank arm lever and clamp necessary for crank arm drive applications.

ADDITIONAL FEATURES: Tradeline pack with cross reference label and instruction sheet.

\section{STANDARD MODELS}

MODELS (also refer to Table I):

M436A Damper Motor-120 or $240 \mathrm{~V}$ ac, sprinq return motor for use with 2 -wire thermostats or other spst controllers. Includes internal adjustable spdt switch for controlling auxiliary equipment.

M836A Damper Motor-24V ac, spring return motor for use with spst controllers without heat anticipation. Includes internal adjustable spdt switch for controlling auxiliary equipment.

M836B Damper Motor-24V ac, spring return motor for use with spst controllers. If circuit has thermostat heat anticipation, the anticipator should be set at $0.75 \mathrm{amp}$. Includes internal adjustable spdt switch for controlling auxiliary equipment.

AMBIENT TEMPERATURE RATING: 32 to 125 F [0 to $52 \mathrm{Cl}$.

FINISH: Gray.

DIMENSIONS: See Fig. 1.

UNDERWRITERS LABORATORIES INC. LISTED (M436A, M836A): File No. E4436, Guide No.XAPX.
AUXILIARY SWITCH RATINGS (in amperes):

\begin{tabular}{l|c|c|}
\hline & $12 U V \mathrm{AL}$ & $24 U V \mathrm{AC}$ \\
\hline Full Load & 7.2 & 3.6 \\
\hline Locked Potor & 43.2 & 21.6 \\
\hline
\end{tabular}

Pilot duty: $40 \mathrm{VA}$ at 120 or $240 \mathrm{~V}$ ac.

AUXILIARY SWITCH ACTION: Spdt-normally open

(R-B) contacts close during the power stroke and open during the return stroke. May be adjusted to operate at any point between 5 and 70 degrees of motor stroke.

ANGULAR STROKE: 75 degrees.

WEIGHT: $4 \mathrm{lb} ., 10 \mathrm{oz} .[2.1 \mathrm{~kg}]$.

OPTIONAL SPECIFICATIONS:

1. M436A with crank arm.

2. $50 \mathrm{~Hz}$ M436A Damper Motors for international applications. Models for 220 or $240 \mathrm{~V}$ ac, with $50 \mathrm{sec}$ opening stroke, 25 sec closing stroke. Includes ground and cover screws and 7640.JL Bag Assembly.

3. $50 \mathrm{~Hz}$ M836A Damper Motor for international applications. Model is for $24 \mathrm{~V}$ ac, with 50 sec opening stroke, $25 \mathrm{sec}$ closing stroke. Includes ground and cover screws and 7640J正 Bag Assembly.

(continued on page 3)

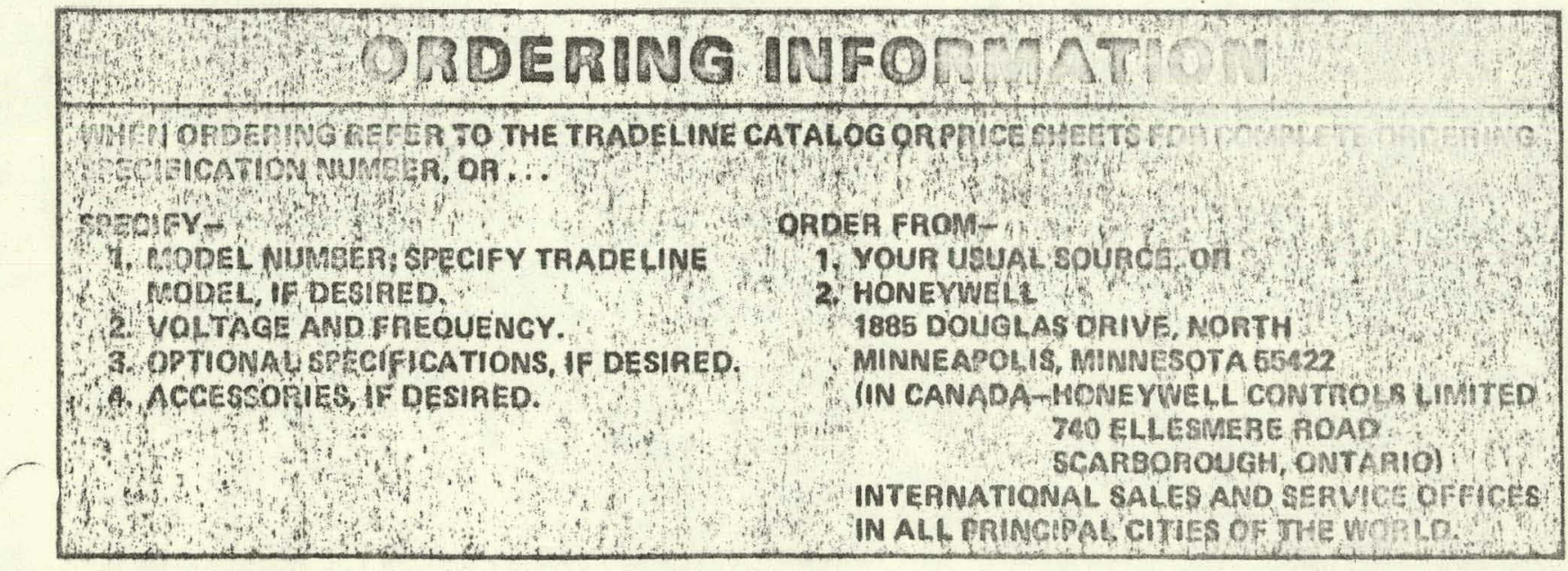


TABLE I

\begin{tabular}{|c|c|c|c|c|c|c|c|c|c|c|}
\hline \multirow[t]{2}{*}{$\begin{array}{l}\text { MODEL } \\
\text { NUMBER }\end{array}$} & \multirow{2}{*}{$\begin{array}{c}\text { VOLT- } \\
\text { AGE } \\
(60 \mathrm{HZ})\end{array}$} & \multicolumn{2}{|c|}{$\begin{array}{c}\text { NOMINAL } \\
\text { CURRENT } \\
\text { (AMP) }\end{array}$} & \multicolumn{2}{|c|}{$\begin{array}{l}\text { NOMINAL } \\
\text { POWER } \\
\text { (WATT) }\end{array}$} & \multirow{2}{*}{$\begin{array}{c}\text { MAXI. } \\
\text { MUM } \\
\text { LOAD } \\
\text { TORQUE } \\
\text { (LB.-IN.) }\end{array}$} & \multirow{2}{*}{$\begin{array}{l}\text { BREAK. } \\
\text { AWAY } \\
\text { TORQUEa } \\
\text { (LB.IN.) }\end{array}$} & \multirow[t]{2}{*}{$\begin{array}{c}\text { OPENING } \\
\text { TIMEB }\end{array}$} & \multirow[t]{2}{*}{$\begin{array}{c}\text { CLOSING } \\
\text { TIMEb }\end{array}$} & \multirow{2}{*}{$\begin{array}{l}\text { DAMPER } \\
\text { BLADE } \\
\text { AREA }\end{array}$} \\
\hline & & OPENING & HOLDING & OPENING & HOLDING & & & & & \\
\hline \multirow{2}{*}{ M436A } & 120 & & 0.12 & $=$ & & \multirow[t]{2}{*}{20} & \multirow[t]{2}{*}{30} & \multirow{2}{*}{$\begin{array}{c}30 \mathrm{sec} \\
\text { (nominal) }\end{array}$} & \multirow{2}{*}{$\begin{array}{c}25 \mathrm{sec} \\
\text { (nominal) }\end{array}$} & \multirow{2}{*}{$\begin{array}{c}13 \\
\text { sq ft }\end{array}$} \\
\hline & 240 & 0.19 & 0.06 & 27.0 & 8.5 & & & & & \\
\hline M836A & 24 & 1.85 & 0.6 & 27.0 & 8.5 & 20 & 30 & $\begin{array}{c}30 \mathrm{sec} \\
\text { (nominal) }\end{array}$ & $\begin{array}{c}25 \mathrm{sec} \\
\text { (nominat) }\end{array}$ & $\begin{array}{l}13 \\
\text { sq fo }\end{array}$ \\
\hline M8368 & 24 & 1.34 & 0.73 & 20.3 & 11.2 & 15 & 30 & $\begin{array}{c}25 \mathrm{sec} \\
\text { (nominal) }\end{array}$ & $\begin{array}{c}25 \text { sec } \\
\text { (nominal) }\end{array}$ & $\begin{array}{c}10 \\
\text { sq } \mathrm{ft}\end{array}$ \\
\hline
\end{tabular}

a Breakaway torque is available to overcome an occasionally frozen or seized damper or valve. THE MOTOR MUST NOT BE USED CONTINUOUSLY AT THIS RATING.

b40 sec maximum.

\section{ACCESSORIES:}

1. 16254AC Bag Assembly-mounting bracket, Part No. 128499, and screws (see Figs. 2 and 6). 2. 7640JE Bag Assembly - drive bushings, adapter, and coupling for direct drive (Figs. 4 and 7 ).

3. 7640JL Bag Assembly-clamp and crank arm lever (for crank arm drive). Refer to Figs. 5 and 6.

4. 7640JM Bag Assembly-mounting bracket, Part No. 126809, and screws (Figs. 3, 4, and 7).
5. 7640JN Bag Assembly-mounting bracket, Part' No. 128336; and screws (Figs. 2 and 6);

6. 4074BRU Bag Assembly-extension adapter and screws for mounting Q607 Auziliary Swritch to M436A Damper Motor.

7. Q298B Linkage-damper crank arms; bushings, $1 / 4$ inch [6.5 mm] steel rod, and ball joint assemblies (Fig. 6).
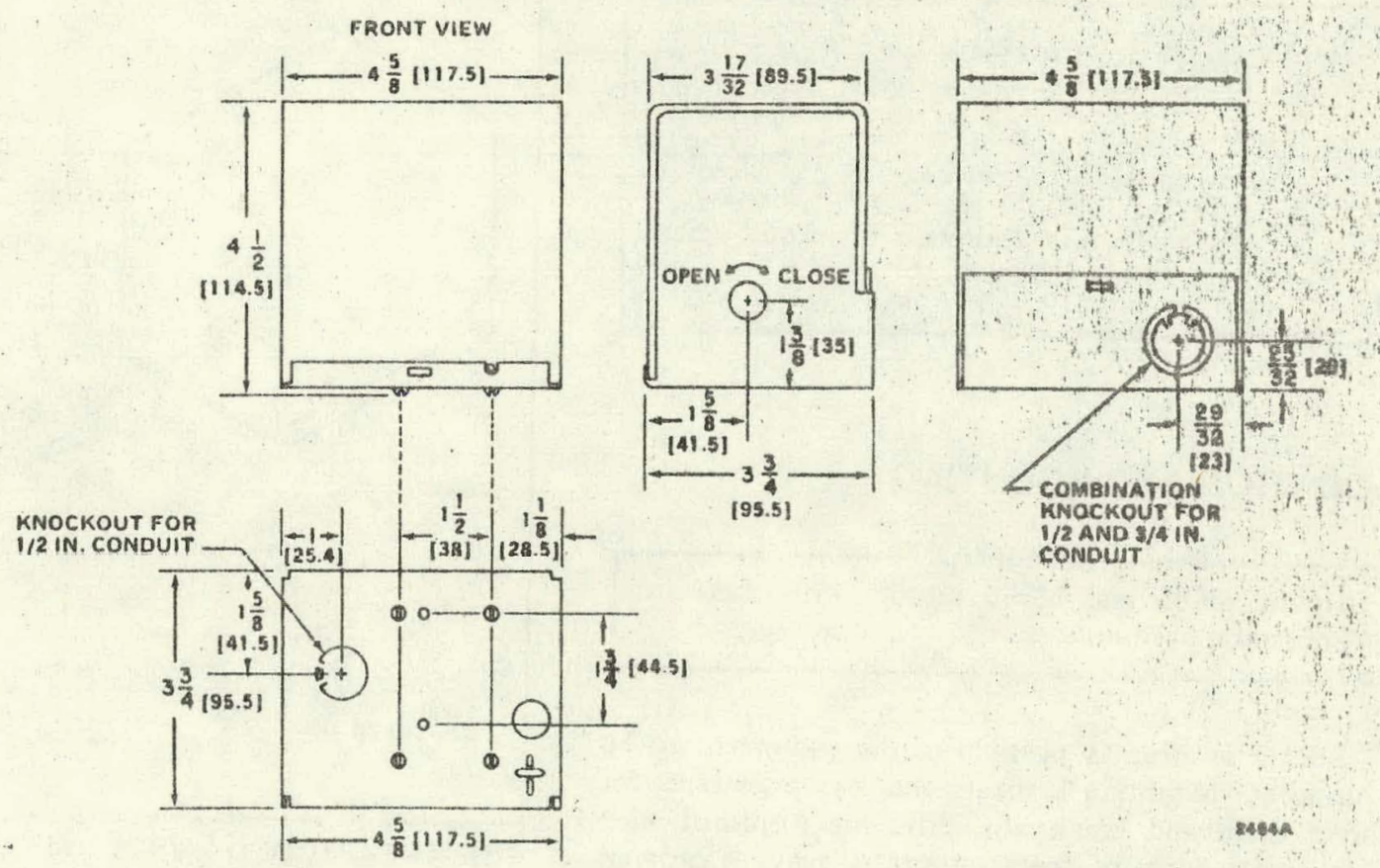

FIG. 1-DIMENSIONS OF M436 AND M836 DAMPER MOTORS, IN INCHES IMILLIMETERS SHOWN IN BRACK[TS]. 


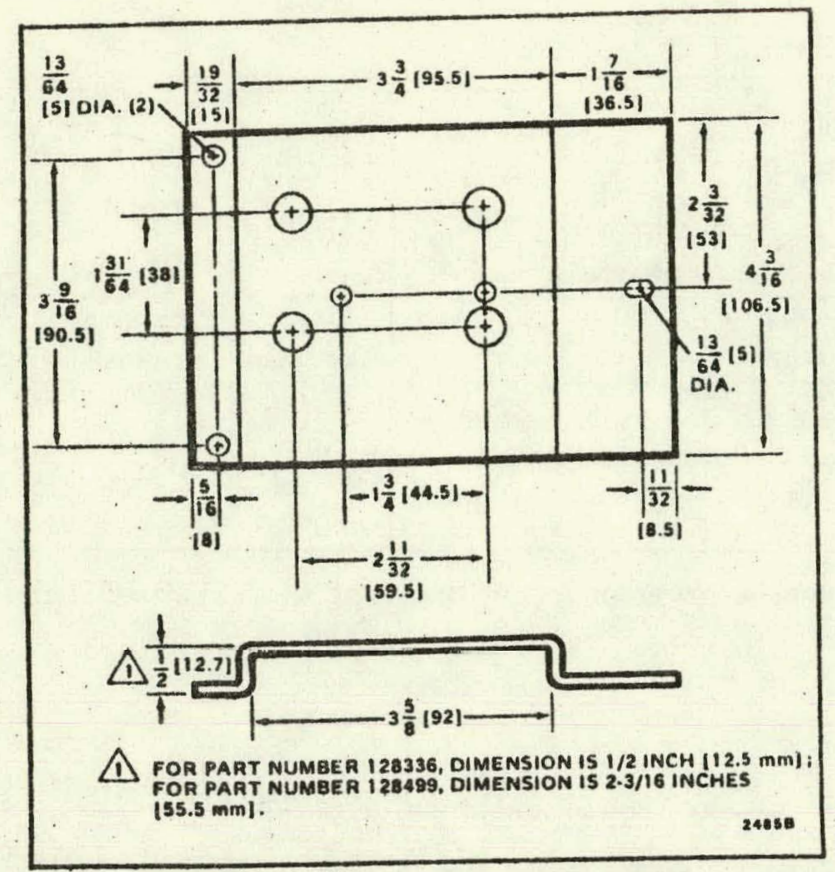

FIG. 2-DIMENSIONS OF 128336 AND 128499 BRACKETS, IN INCHES [MILLIMETERS SHOWN IN BRACKETS].

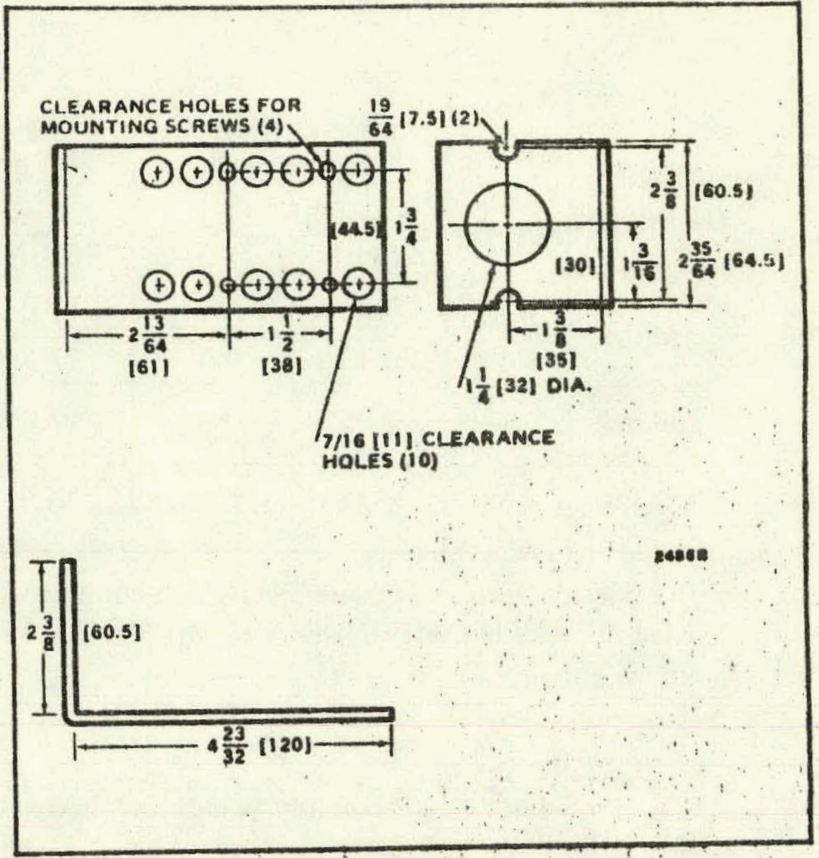

FIG. 3-DIMENSIONS OF 126809 BRACKET, IN INCHES [MILLIMETERS SHOWN IN BRACKETS].

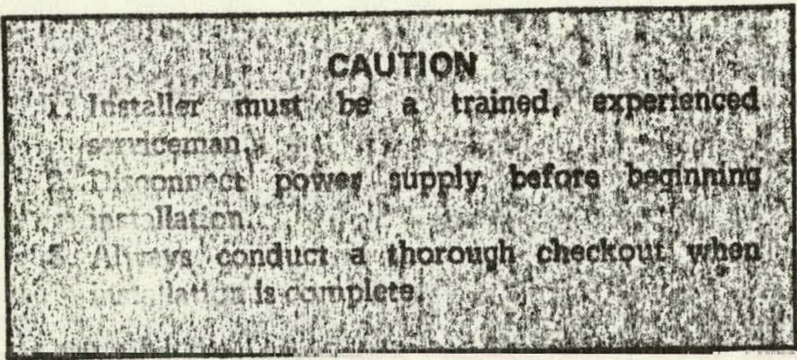

\section{LOCATION AND MOUNTING}

\section{IMPORTANT}

Mount M436 and M836 motors with shaft in horizontal position.

Locate as near as possible to the equipment to be controlled. Mounting brackets and bag assemblies for direct drive and crank arm drive are furnished with Tradeline models of these motors or may be ordered separately if required for the installation. Refer to the Accessories section for specifications, Figs. 2 and 3 for dimensions, and Figs. 4.7 for installation drawings.

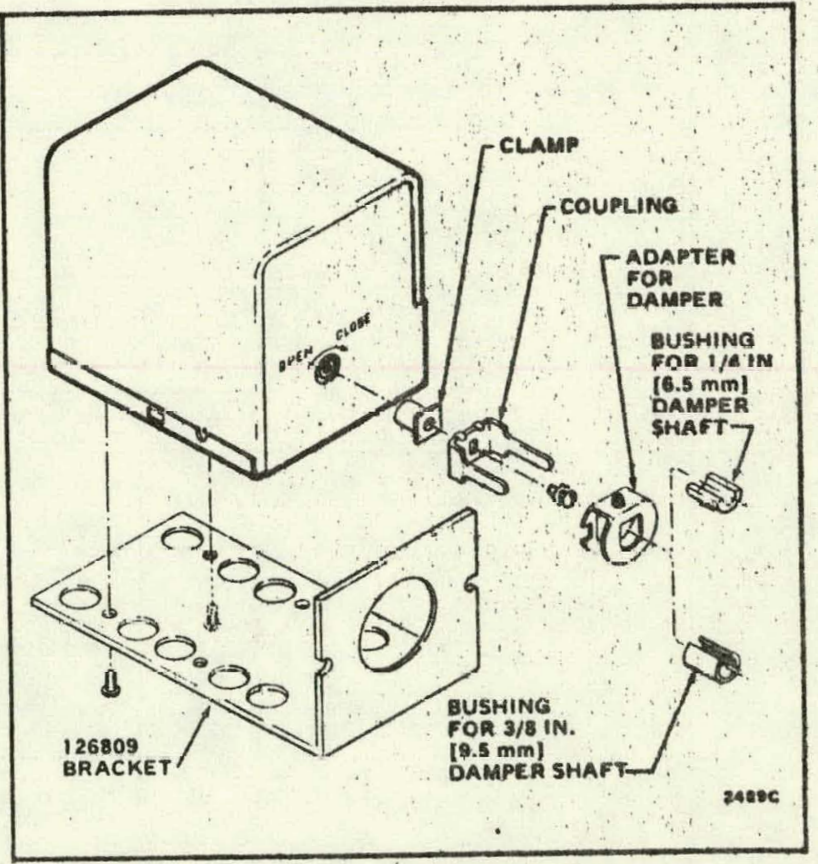

FIG. 4-EXPLODED VIEW SHOWING HOW TO MOUNT 7640JE DAMPER SHAFT COUPLING AND 7640JM MOUNTING BRACKET ASSEMBLY TO MOTOR. 


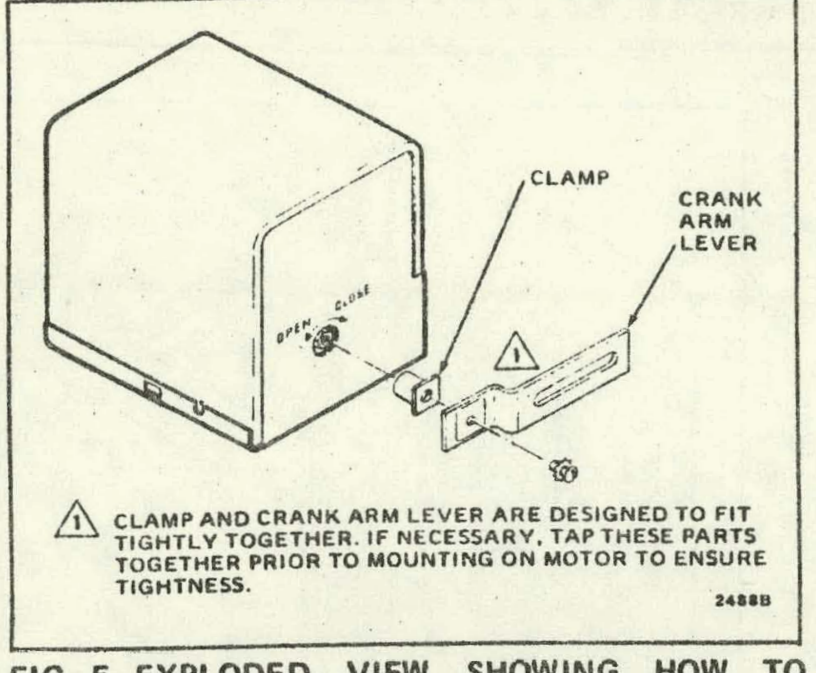

FIG. 5-EXPLODED VIEW SHOWING HOW TO MOUNT 7640JL CRANK ARM ASSEMBLY TO MOTOR.

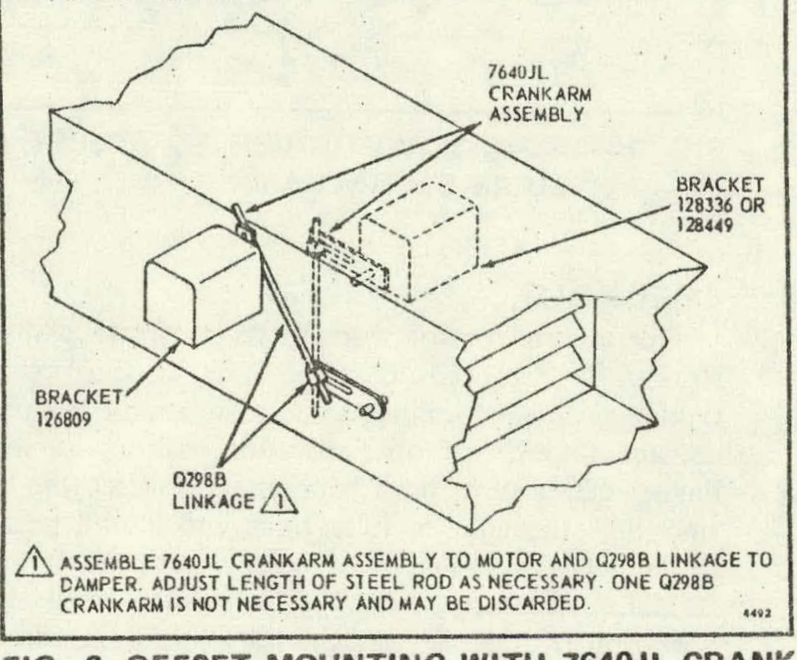

FIG. 6-OFFSET MOUNTING WITH 7640JL CRANK ARM ASSEMBLY AND O298B LINKAGE.

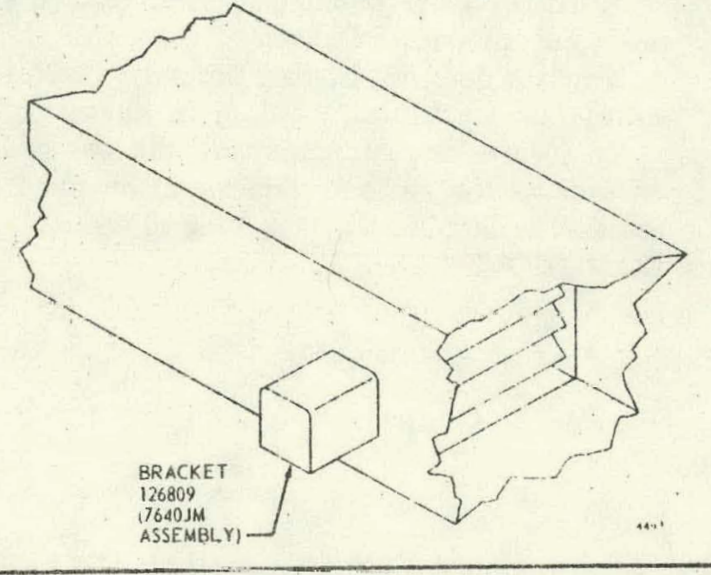

FIG. 7-DAMPER MOTOR DIRECTLY COUPLED TO DAMPER USING 7640JM MOUNTING BRACKET ASSEMBLY AND 7640JE DRIVE COUPLING ASSEMBLY.

\section{WIRING}

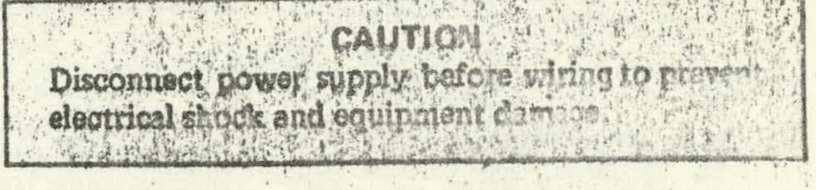

All wiring must comply with applicable local codes, ordinances, and regulations. Refer to Figs. 8 and 9 for typical hookup diagrams and to information furnished with the system equipment.

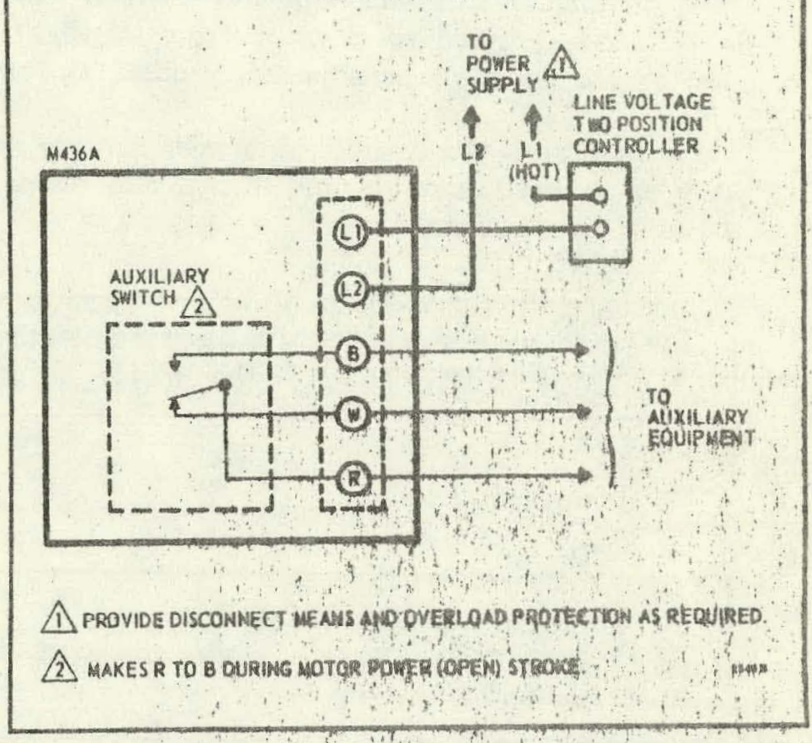

FIG. 8-TYPICAL HOOKUP OF MA36 DAMPER MOTOR.

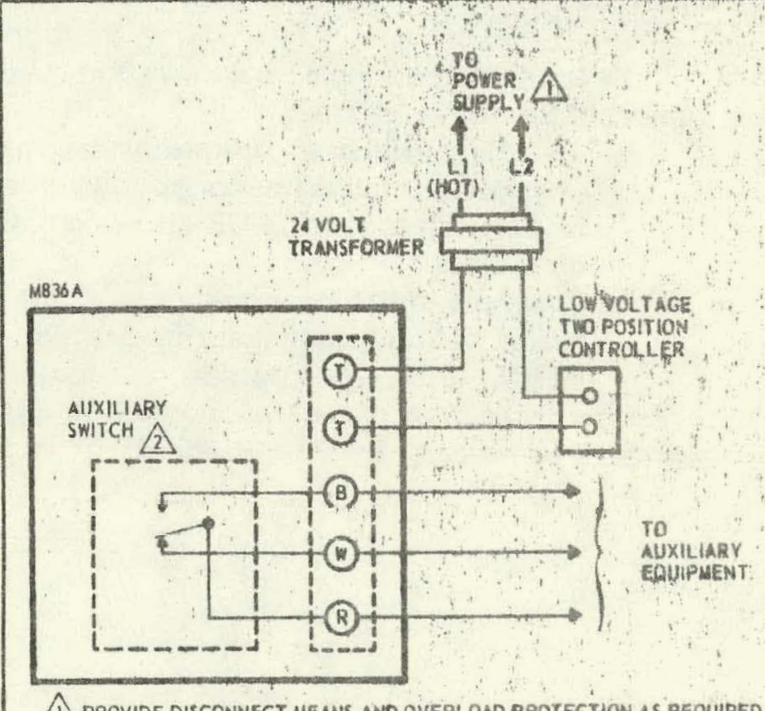

(1) PROVIDE DISCONNECT MEANS AND DVERLOAD PROTECTION AS REQQUIRED 2. MAKESR TO B QURING MOTOR POWER (OPEM) STROKE.

as res

FIG. 9-TYPICAL HOOKUP OF M836 DAMPER MOTOR. 


\section{AUXILIARY SWITCH ADJUSTMENT}

The internal spdt auxiliary switch of the M436/M836 can be adjusted to operate at any point between 5 and 70 degrees of the motor stroke. It has a $1-2$ degree nonadjustable differential. The switch makes $R \cdot B$ during the power stroke (motor shaft moves in direction of the OPEN arrow on outside of case).

Power the motor so it runs to the open position. Note the point of the motor stroke at which the switch operates (audible click, or check for continuity across R-B terminal). If switch operates correctly for the application, proceed to check out the installation. If the switch needs to be adjusted, proceed as follows.

1. Determine the number of degrees that the switch cam must be adjusted to operate switch at the desired point of motor stroke.

IMPORTANT

Switch should not be adjusted to operate closer than 5 degrees from ends of the motor stroke.

\section{Remove motor cover.}

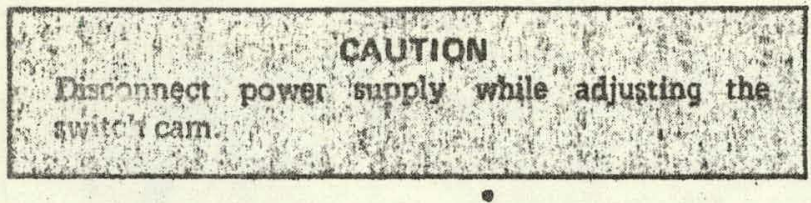

3. Insert a screwdriver in a slot in the switch cam (white plastic) located near the center of the motor. Refer to the cutaway view, Fig. 10. Each slot in the cam equals approximately 20 degrees of motor rotation.

4. Select a reference point and move cam the correct number of degrees as follows.

a. To adjust switch to operate nearer the open (maximum rotation) motor position, move cam in direction of the CLOSE arrow on outside of motor case.

b. To adjust switch to operate nearer the closed motor position, move cam in direction of the NPFN arrow on outside of motor case.

Repower the motor and check point at which the switch makes and breaks. Readjust if necessary.

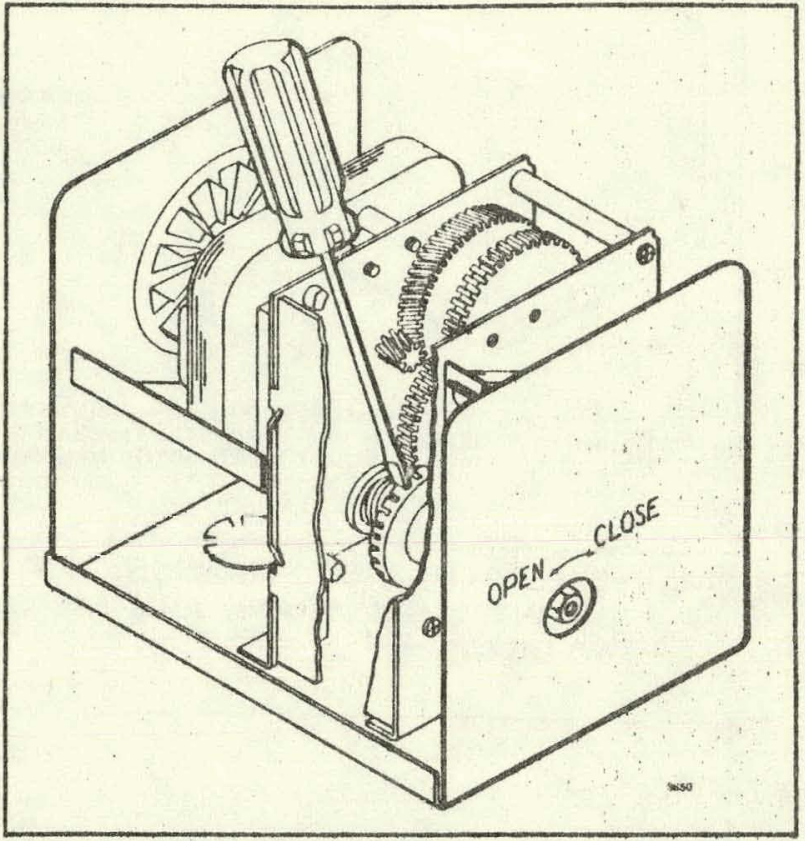

FIG. 10-USING SCREWDRIVER TO ADJUST AUXILIARY SWITCH CAM.

\section{CHECKOUT}

Operate the motor through its complete open-close stroke. Be prepared to release one of the previously tightened linkage connections, if necessary, to prevent damage. Check for proper operation, making sure that the linkage does not bind and that the motor travels smoothly through its fully open and closed positions. If there is excess length of linkage rod, cut it to size.

Make necessary minor adjustments until desired operation is obtained, and tighten all nuts and setscrews. A motor checkout should prove that:

1. The motor operates the load.

2. The motor responds properly to the controller.

3. There is no binding of the linkage of motor stalling at any point of travel.

If motor does not operate properly, check for proper voltage or mechanical binding in linkage or damper.

To insure long life, lubricate the felt pads located on each of the sublor bearings and on the 2 shafts in the gear train annually. Use Anderol 465 or equivalent. DO NOT OVER LUBRICATE. 


\section{The BTU Savers Keep Air Flow Under Control Cut Heating/Cooling Energy Costs}

Using louvered dampers to control air flow in a temperature control system is a concept as old as air conditioning itself. Honeywell's excellence in the field of temperature control continues with the high quality line of Moduflow dampers. The difference between Honeywell's modern, well engineered dampers and others in use today is as great as the difference between modern freon compressors and the early ammonia machines.

Moduflow dampers are designed with the needs of the final consumer in mind and engineered to meet the most demanding air flow control requirements. They are manufactured in a factory devoted entirely to damper production, utilizing the most modern metal fabrication machinery and processes.

\section{Features}

All Honeywell dampers are designed to provide economical air flow control, yet the D640 and D641 standard Honeywell dampers cut in half the amount of leakage allowed by an ordinary damper. When even more stringent requirements are demanded the D642 through D645 low leakage Moduflow dampers cut leakage to one half of one percent of the rated flow. With these features Honeywell dampers can keep costly heating and cooling energy from escaping through intake, exhaust, or hot/cold deck dampers.

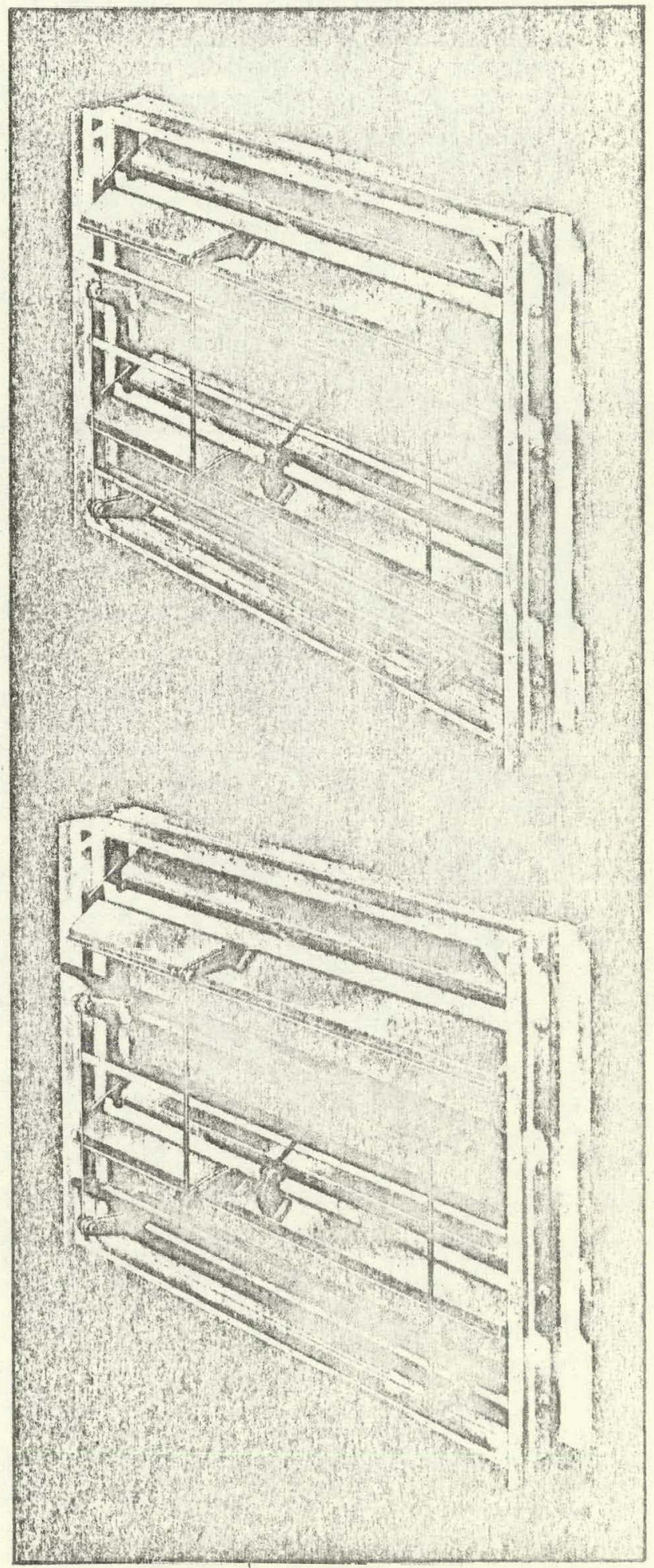

*Trademark

Rev. 4.76

M.J.C. 


\section{Dampers}

Honeywell dampers provide two levels of performance in the area of pressure, velocity, and leakage. The D640 parallel blade and D641 opposed blade standard Honeywell dampers meet most application requirements in these areas. However, the D642 and D643 low-leakage Moduflow dampers are available as explained in the following text.

Low leakage Moduflow dampers allow for ultra-low leakage while providing high velocity characteristics for both high and low pressure applications. These dampers utilize many parts common to the standard dampers but important differences in construction give them characteristics needed to meet the most demanding requirements. These dampers are available as the D642 and D644 parallel blade dampers, or the D643 and D645 opposed blade dampers. The D644 and D645 are especially useful in smoke damper applications.

Honeywell's Moduflow dampers have taken their place alongside the thermostat, control valve, and other precision control devices that go into making up a complete automatic control system. These dampers are designed for vertical or horizontal mounting with precise air flow control and superior construction as prime criteria.

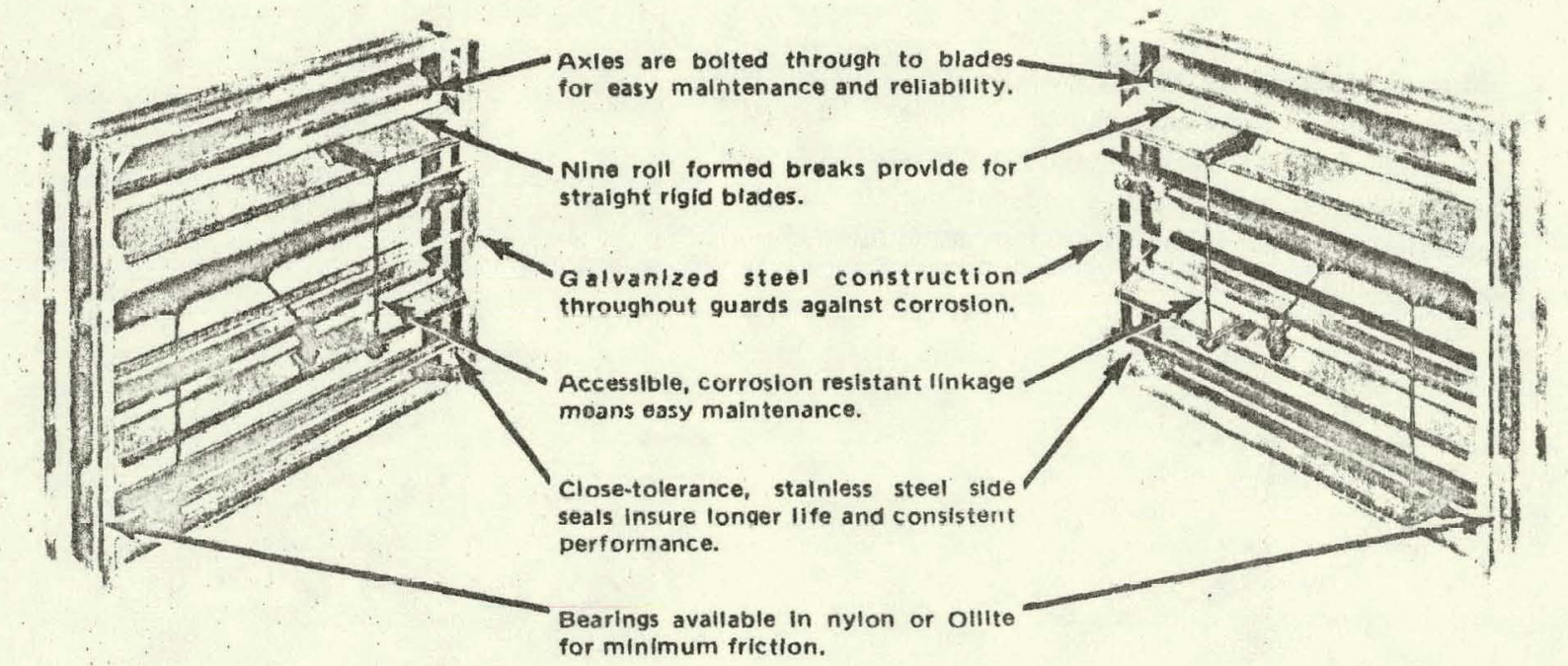

D841: OPPOSED BLADE MODUFLOW DAMPER ILLUSTRATED. D640: PARALLEL BLADE MODUFLOW DAMPER ALSO AVAILABLE.
D643 \& D645: OPPOSED BLADE INFLATABLE SEAL MODUFLOW DAMPERS ILLUSTRATED. D642 \& D644: PARALLEL BLADE INFLATABLESEAL DAMPERS ALSO AVAILABLE. 


\section{Honeywell}

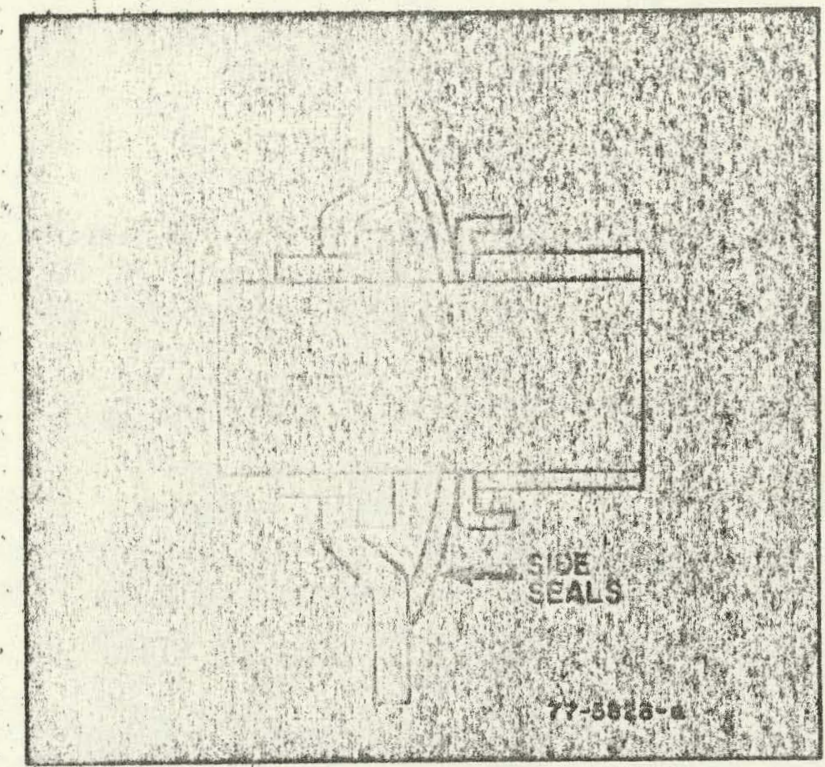

Fig: 1-Continuous Spring Stainless Steel Side Seals Cut Leakage to a Minimum, Promote Longer Seal Life, and Consistent Performance.

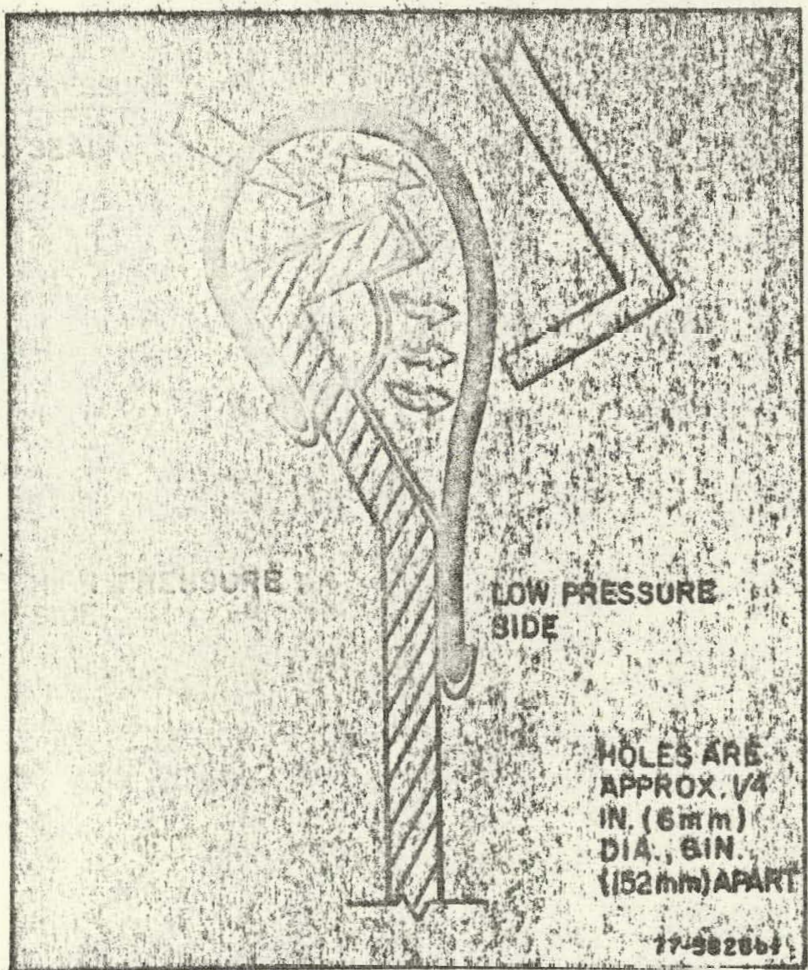

Fig. 2-Inflatable Seals Give Maximum Seal Off at High Pressures.

\section{Specifications}

\author{
Honeywell dampers include the following high quality \\ construction features:
}

SIZES

Dampers range from $8 \mathrm{in.}(203 \mathrm{~mm})$ horizontal and vertical to 48 in. $(1219 \mathrm{~mm})$. Size increases in two inch $(51 \mathrm{~mm})$ increments. Requirements of more than 48 inches $(1219 \mathrm{~mm})$ are made up of conventional dampers connected as multisection units either vertically or horizontally with easy to install hardware. NOTE: Minimum size for opposed blade dampers is 14 in. $\times 14$ in. (356 $\mathrm{mm} \times 356 \mathrm{~mm})$.

\section{FRAME}

Horizontal members are roll formed $.094 \mathrm{in} .[(2.4 \mathrm{~mm})$ approx. 13 gaugel galvanized steel channel with "triple $U$ " cross section for extra frame stiffness. Vertical frame members are roll formed $.094 \mathrm{in}$. $(2.4 \mathrm{~mm})$ galvanized steel, extra deep for frame strength (sea Fig. 3 ).

\section{BLADES}

All but the 12 -in. $(305 \mathrm{~mm})$ dampers use 6 - or 8 -inch $(152$ ar $203 \mathrm{~mm}$ ) blades or a combination of both. A single 10-in. $(254 \mathrm{~mm})$ blade is used on 12-inch $(305 \mathrm{~mm})$ dampers. Blades are roll formed $.062 \mathrm{in}$. [(1.6mm) approx. 16 gauge] steel for blade rigidity.

The drive blade on D640/D641 dampers with a harizontal dimension of 36 inches $(914 \mathrm{~mm})$ or larger is reinforced with a .062 -in. $(1.6 \mathrm{~mm})$ stiffener plate. Inflatabie seal dampers 30 inches $(162 \mathrm{~mm})$ and larger have all blades reinfuiced.

\section{BLADE SEALS}

Blade ends are sealed with tight-clearance, spring stainless steel continuous seal strips. On standard Moduflow dampers the mating edges of blades meet with interlocking formed steel edges. Closed cell neoprene foam ediging $[3 / 16 \times 1 / 2$ in. $(5 \times 13 \mathrm{~mm})]$ is optional for mating edges. On low leakage dampers inflatable seal blade edges are expandable, fabric-reinforced neoprene rubber to insure minimum leakage (see Fig. 2).

\section{HARDWARE}

Linkage bracket and linkage connecting rods (5/16 in. (8/mm) dia.l are zinc plated steel. All trunnion rods are brass. Set screws and mounting bolts are zinc plated. Bearings are nylon (standard) with Oilite bearings optional. 


\section{Dampers}

\section{SPECIAL MODELS}

D644 and 0645 high temperature dampers are available for high temperature applications such as smoke dampers. They are constructed and have characteristics similar to D642/D643 low leakage inflatable seal dampers but have higher temperature ratings.

\section{AXLES}

All axles are $1 / 2 \mathrm{in.}(13 \mathrm{~mm})$ diameter zinc plated steel. Axles are fastened to the blades with through bolts. Drive blades on all dampers have adjustable axles that can extend to 4 inches $(102 \mathrm{~mm})$ beyond the frame.
FINISH

Galvanized steel frame and blades.

\section{OPERATOR MOUNTING}

Mounting lugs are furnished for internally mounted pncumatic or electric operators. Drive blades feature extendable axles for external operator mounting.

\section{TEMPERATURE RANGES}

D640-D643; 40 to $200 \mathrm{~F}$ ( -40 to $93 \mathrm{C})$. D 644 \& D $645 ;-40$ to $400 \mathrm{~F}(-40$ to $202 \mathrm{C})$.

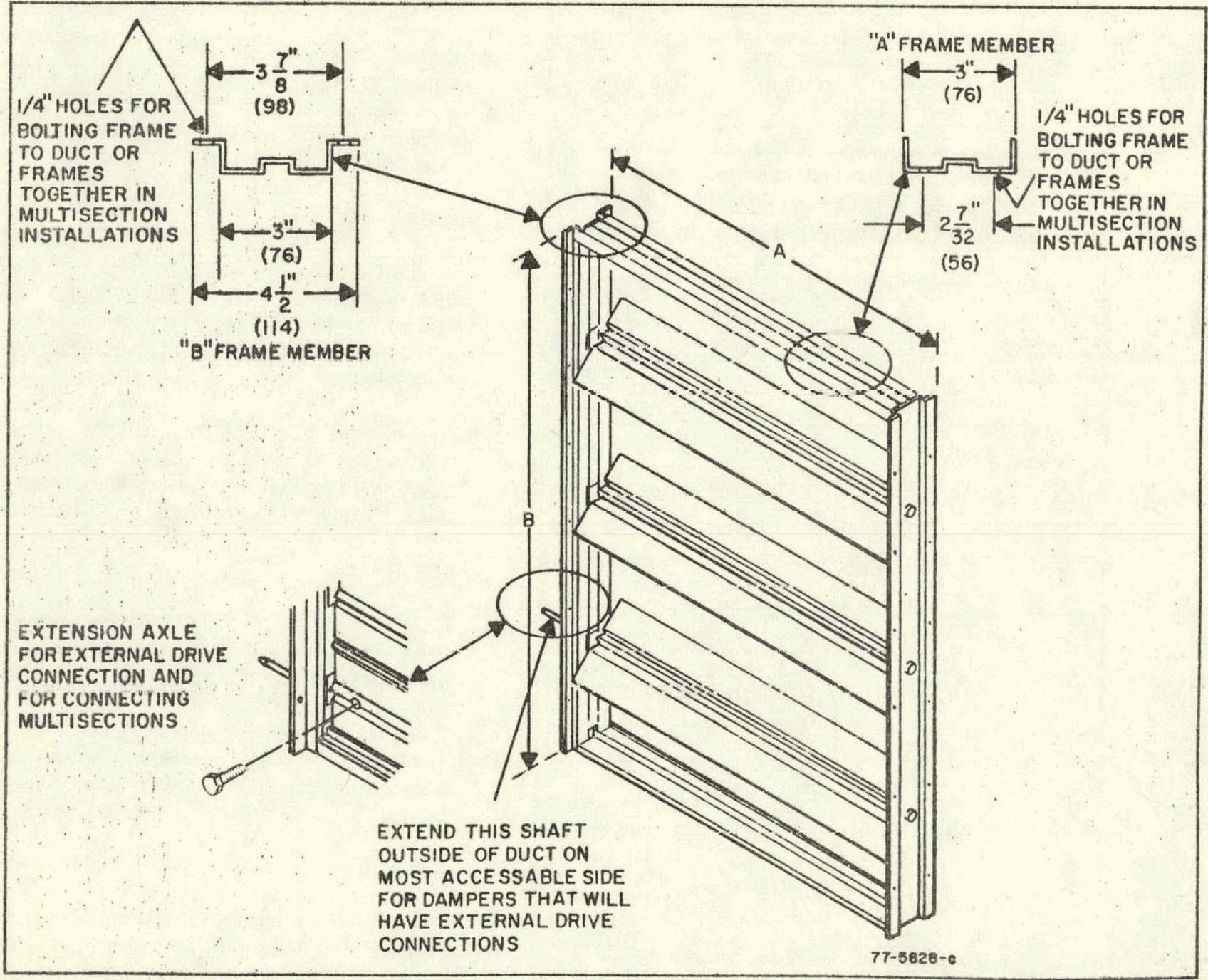

Fig. 3-Frame Member Cross Section Construction and Dimensions in Inches (Millimeters). 
MAXIMUM PRESSURE DIFFERENTIAL

D640/0641 - 3 in. we $(76 \mathrm{~mm})$.

D642.0645 - 6 in. wc $(152 \mathrm{~mm})$.

\section{MAXIMUM APPROACH VELOCITY (Non-Turbulent)}

$0640 / 0641 \cdot 1500 \mathrm{fpm}(7.7 \mathrm{~m} / \mathrm{s})$

D642-D645 - $4000 \mathrm{fpm}(20 \mathrm{~m} / \mathrm{s})$.

\section{VEATICAL BLADE CONSTIAUCTION}

All models of Moduflow dampers are available with special construction features for mounting with the blades in the vertical position. A slight increase in leakage can be expected.

\section{ROLL FORMED FRAMES AND BLADES}

These dampers are constructed of high quality material and are manufactured with automated roll forming and automatic welding machines. This increases the consistency in quality and guarantees completely uniform dampers. The consistence in dimensions, square frames, and close talerances is especially important for multisection damper construction.

\section{MULTISECTION DAMPERS}

Individual Honeywell Moduflow dampers are constructed in "nominal" sizes ranging up to 48 inches $(1219 \mathrm{~mm})$ on either measurement, in two-inch $(51 \mathrm{~mm})$ increments. For applications requiring dampers larger than 48 inches $(1219 \mathrm{~mm})$ dampers are supplied as multisection units (see Fig. 4). Figures $4 a$ and $4 b$ show typical vertical and horizontal expansion of two-section dampers.
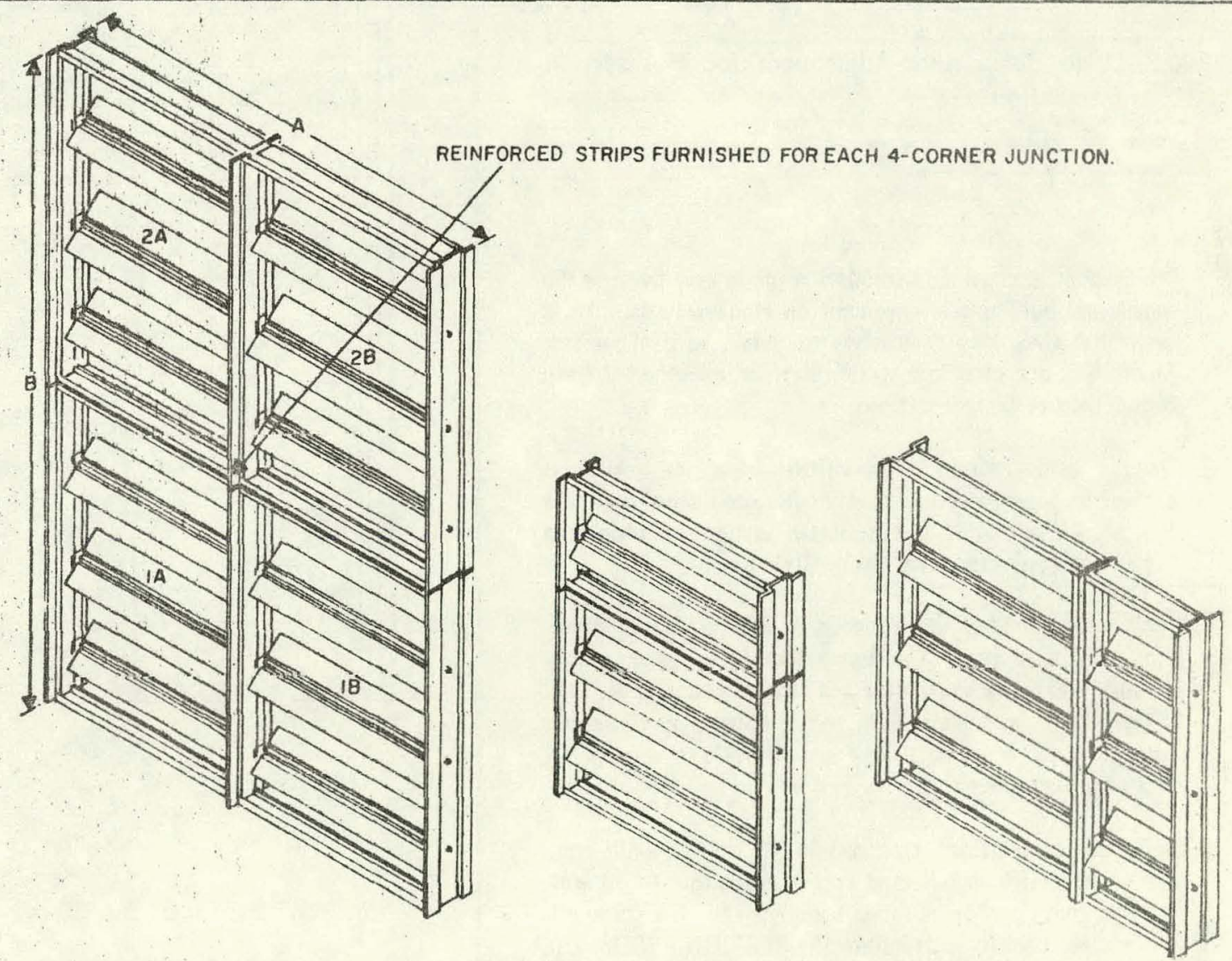

Fig. 4-Multisection Damper Construction (Horizontal Blade).

Fig. 4a-Vertical Expansion. Fig. 4b-Horizontal Expansion. 


\section{Moduflow* Dampers}

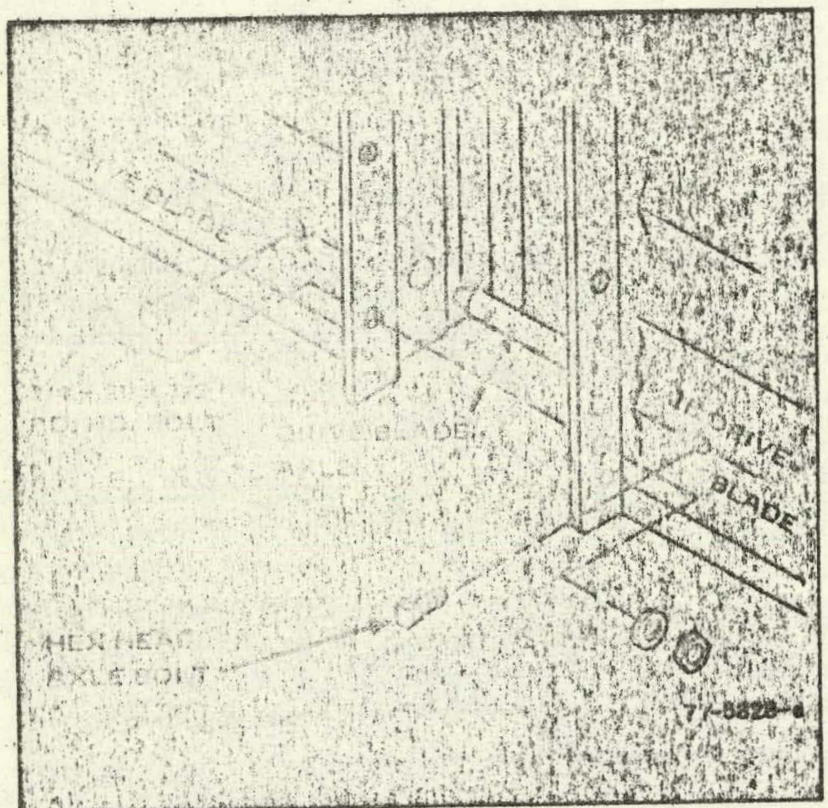

Fig. 5-Drive Blade Axle Adjustment for Multisection Installation.

Multisection damper construction is made easy because the flange and bolt hole arrangement on Honeywell dampers is such that they lend themselves to quick, easy alignment. Figure 4 is a typical four-section damper, constructed from four equal size damper sections.

Damper blade motion is transmitted from one horizontal section to another by use of interconnected drive axles (see Fig. 5). Blade motion is transmitted vertically through the use of interconnected drive linkages (see Fig. 6).

Honeywell's dampers are designed to minimize installation effort and save time. The frame and blade construction provides maximum squareness and rigidity (see Fig. 3). The flanged " $B$ " frame members make bolting multisection dampers together easier. They also provide a convenient means for duct mounting.

Moduflow dampers are packaged in $10 \mathrm{mil}$, polyethylene, shrink pack with linkage and corner protectors to prevent damage during storage and handling. In the case of multisection damper installations the SECTION ASSEMBLY KEY (Fig. 7) is visible without opening the package until it is time to install that damper section.

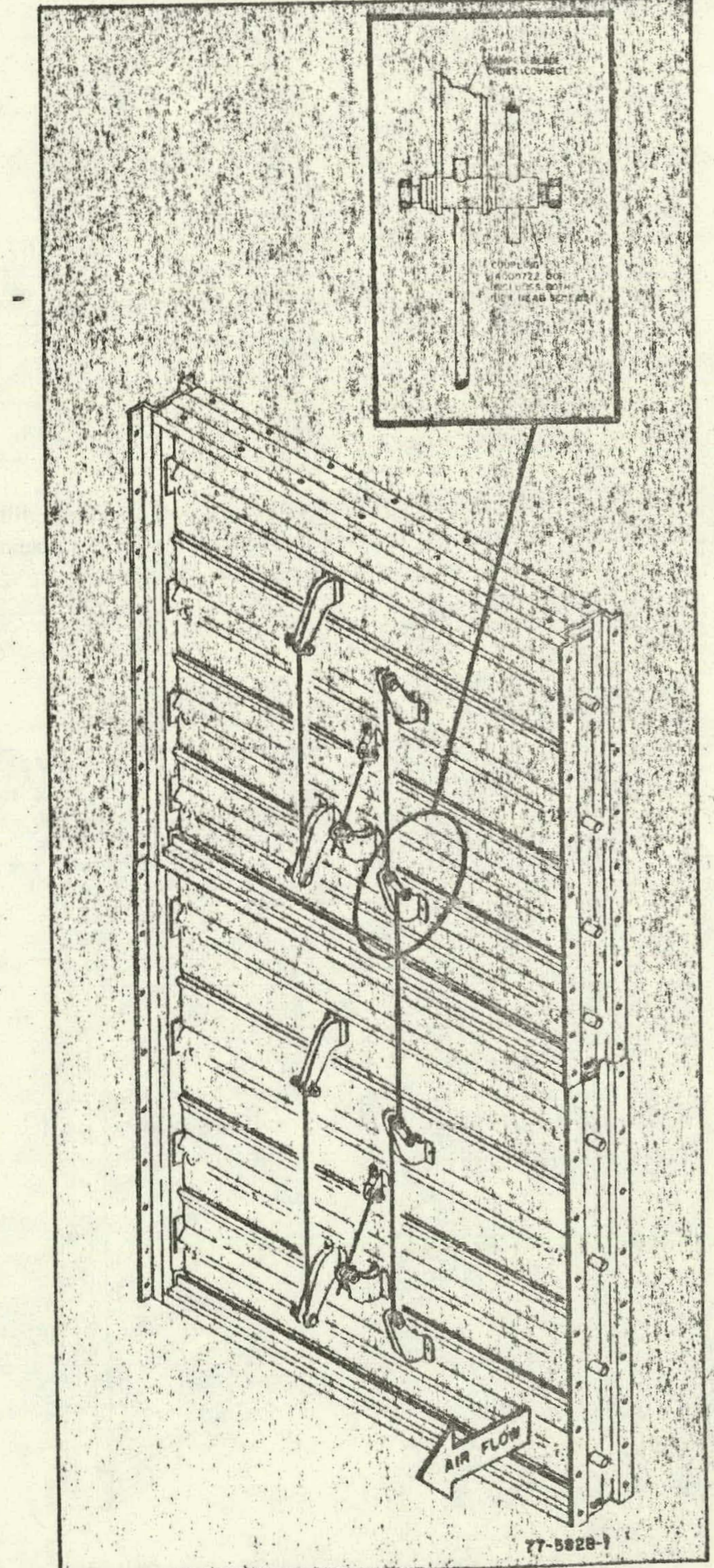

Fig. 6--Attaching the Vertical Section Drive Linkage. 


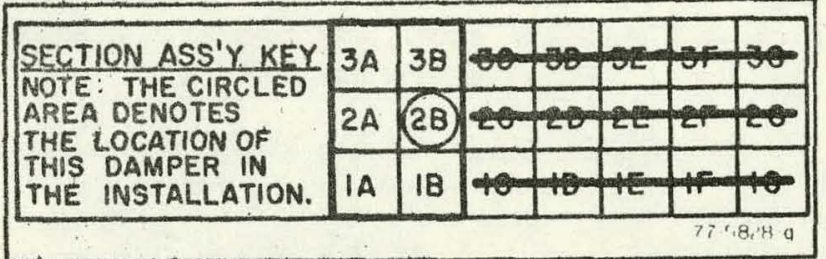

Fig. 7-Section Assembly Key Label for Multisection Dampers (as viewed from the downstream side).

This section assembly key informs the installer not only of the location of the particular damper in hand but also how many sections ( 6 in example) will make up the complete installation.

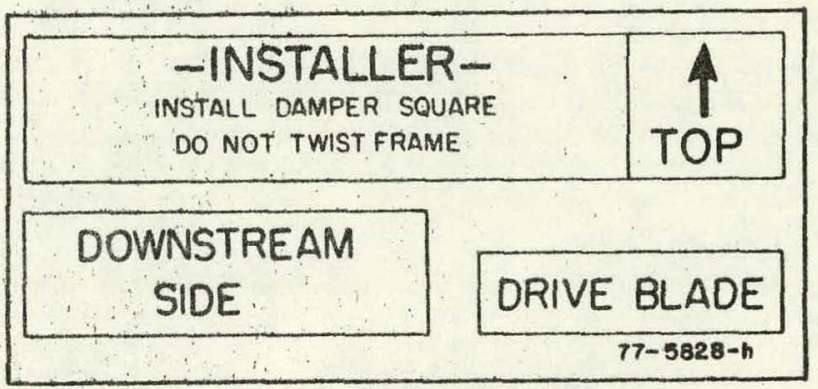

Fig. 8-Damper Installation Labels.

The labels shown in Figure 8 are also attached to the damper bfades. Mounting the low leakage damper with the DOWNSTREAM SIDE label on the proper side insures maximum close-off and smooth operation of the damper motor.

The INSTALLER label has an important message for the installer. Misalignment of the damper can cause twist in the frame creating blade and linkage bind. This in turn will overload the damper motor or render it inoperative.

Located on the bottom blade of Moneywell dampers is the DRIVE BLADE label. It is important that the damper operator be connected to this blade only. On standard dampers 36 inches $(914 \mathrm{~mm})$ and larger the drive blade is reinforced to prevent twist caused from the torque of the operator. (The drive blade is the only blade reinforced on standard dampers.) On low leakage dampers 30 inches $(762 \mathrm{~mm})$ and larger all blades are reinforced.

\section{RULES FOA INSTALLATION}

Damper blades must always be installed horizontally except in the case of the special vertical blade models of each damper. Vertical dampers are constructed differently from horizontal dampers and the two cannot be interchanged. However, installation procedures for them is almost the same.

To work smoothly dampers must be installed square and plumb (flat).

Allow at least 8 inches $(203 \mathrm{~mm})$ clearance front and back for correct damper blade operation.

Dampers larger than 48 inches $(1219 \mathrm{~mm})$ will be provided as multisection units.

Multisection damper installations larger than 96 inches $(2438 \mathrm{~mm})$ will require field fabricated bracing. The brace should be from the damper framing near the center of the assembly to the floor, ceiling beams, duct framing, or other solid structural member adjacent to the damper.

DO NOT WELD MULTISECTIONS TOGETHER, use the bolts provided.

MASK THE SIDE SEALS NEXT TO THE DAMPEA BLADES if field painting is required.

Dimension " $A$ " always represents blade length (either, vertical or horizontal).

\section{LEAKAGE}

The design and construction of a damper will determine how much separation will exist between the blades and the frame. Any separation reduces the efficiency of the damper.

If a damper is not constructed with effective sealing elements, the amount of leakage will be proportional to the amount of differential pressure applied to the blade. Causing the blades to twist by increasing the clasing force has little effect on reducing leakage.

However, closing force is important when a compression type seal is used. The force available must be great enough to compress the seal from its first point of contact to its last point of contact. This force must be stated for true damper comparisons.

The effect of damper leakage may be to:

Decrease capacity of a unit;

Limit controllability;

Limit effectiveness of isulation as in smoke damper applications;

Waste valuable energy. 


\section{Moduflow* Dampers}

The leakage ratings of simple dampers average approximately $50 \mathrm{cfm} / \mathrm{sq}$. ft. $\left(0.25 \mathrm{~m}^{3} / \mathrm{sec} / \mathrm{m}^{2}\right)$ with 1.5 in water static pressure.

Provisions which Honeywell takes to insure minimal leakage on standard dampers are:
BLADES - Constructed of .062 in. galvanized steel with nine longitudinal "breaks" in the cross section to provide rigidity plus reinforcing of the drive blade.

BLADE SEALS - Mating edges of the standard dampers meet with interlocking formed steel edges.

Following are nominal leakage figures for the Honeywell line of dampers:

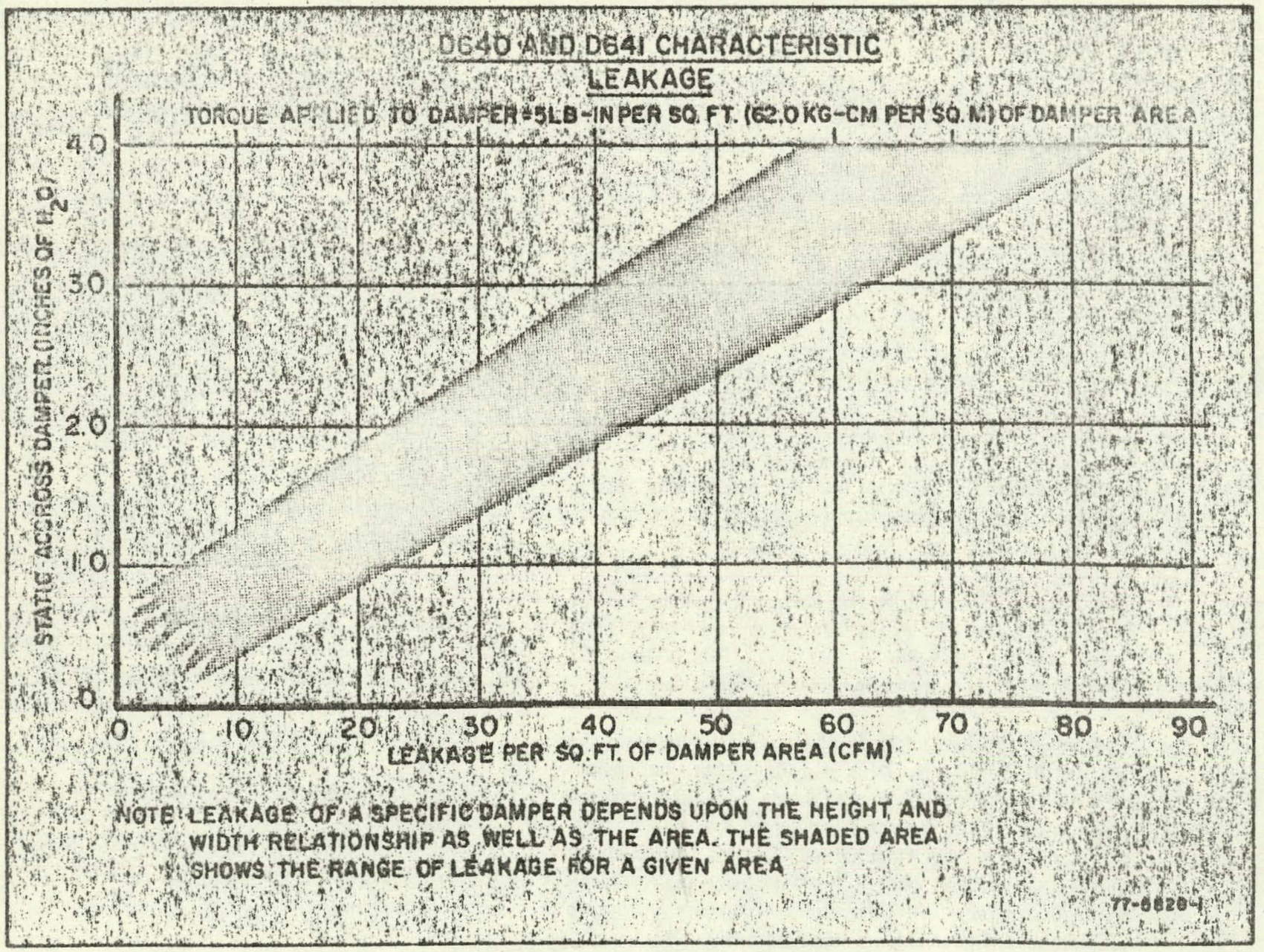

Fig. 9-D640, D641 Standard Damper Leakage Curve. 


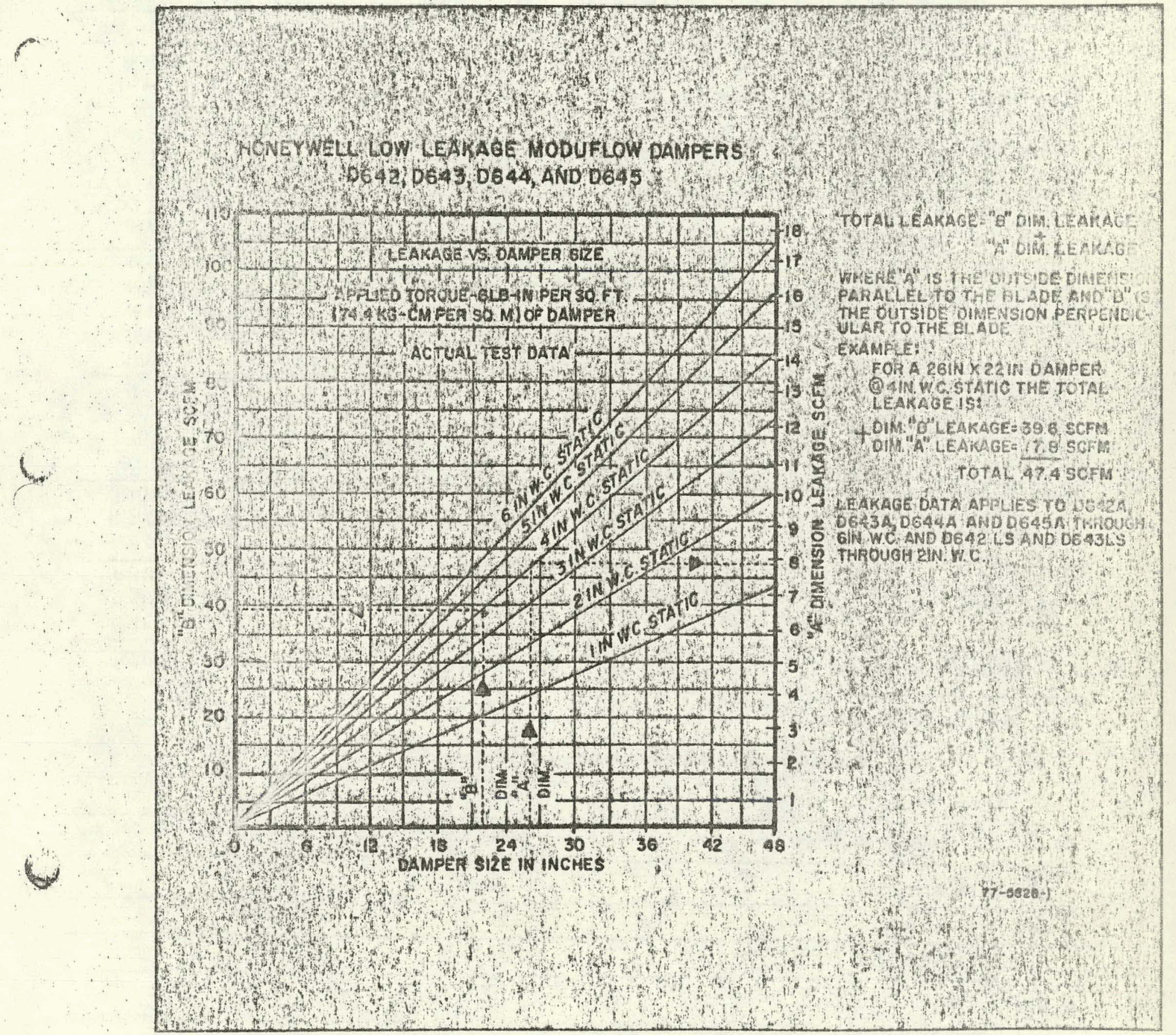

Fig. 10-D642 Thru D645 Damper Leakage Curves. 
Table 1-Maximum Damper Operator Rating in Square Feet (Square Meters) of Damper Area.

\begin{tabular}{|c|c|c|c|c|c|c|c|}
\hline & nper & \multicolumn{3}{|c|}{0640 \& $064 ?$} & \multicolumn{3}{|c|}{ D642 \& DG43 } \\
\hline \multicolumn{2}{|c|}{ Typa Operation } & \multicolumn{2}{|c|}{ Moduleting Service } & \multirow{2}{*}{$\begin{array}{c}2 \text { Pos. Service } \\
\begin{array}{c}18 \mathrm{psi} M \\
(125 \mathrm{kPa})\end{array}\end{array}$} & \multicolumn{2}{|c|}{ Modulating Service } & \multirow{2}{*}{ 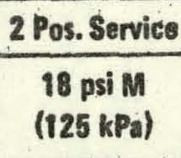 } \\
\hline Motor & $\begin{array}{l}\text { Spring } \\
\text { psi (kPa) }\end{array}$ & $\begin{array}{l}13 \text { psi } \\
(50 \mathrm{kPat}\end{array}$ & $\begin{array}{l}18 \text { psi M } \\
(125 \mathrm{kPa})\end{array}$ & & $\begin{array}{l}13 \text { psi M } \\
(90 \mathrm{kPa})\end{array}$ & $\begin{array}{l}18 \mathrm{psi} M \\
(125 \mathrm{kPa})\end{array}$ & \\
\hline $\begin{array}{c}\text { MPg09A } \\
" \\
" \\
" \prime \\
" \prime\end{array}$ & $\begin{array}{l}2.7(15.50) \\
3.13(20-90) \\
5.10(35.70) \\
7.13(50-90) \\
10.15(70.105)\end{array}$ & $\begin{array}{c}2(.2)^{*} \\
3.5(3) \\
\ldots .6 \\
\cdots\end{array}$ & $\begin{array}{l}2(.2)^{*} \\
4(.4) \\
4(.4) \\
4(.4) \\
4(.4)\end{array}$ & $\begin{array}{l}2(.2) \\
3.5(.3) \\
5.5(.5) \\
5.5(.5) \\
3.5(.3)\end{array}$ & $\begin{array}{l}1.5(.1)^{*} \\
\cdots . . \\
3(.3) \\
\cdots \\
\cdots\end{array}$ & $\begin{array}{l}1.5(.1)^{*} \\
3(.3) \\
3(.3) \\
3(.3) \\
3(.3)\end{array}$ & $\begin{array}{l}1.5(.1) \\
3(.3) \\
4.5(.4) \\
4.5(.4) \\
3(.3)\end{array}$ \\
\hline $\begin{array}{c}\text { MP909B } \\
" \\
" \\
" \\
"\end{array}$ & $\begin{array}{c}2.7(15.50) \\
3-13(20-90) \\
5-10(35-70) \\
7.13(50-90) \\
10-15(70-105)\end{array}$ & $\begin{array}{c}5(.5)^{\circ} \\
8(.7) \\
\cdots \\
\cdots\end{array}$ & $\begin{array}{l}5(.5)^{*} \\
8(.7) \\
8(.7) \\
8(.7) \\
8(.7)\end{array}$ & $\begin{array}{c}5(.5) \\
8(.7) \\
12(1.1) \\
12(1.1) \\
8(.7) \\
\end{array}$ & $\begin{array}{l}4(.4)^{*} \\
\cdots . \\
7(.7) \\
\cdots \ldots \\
\cdots\end{array}$ & $\begin{array}{l}4(.4)^{n} \\
7(.7) \\
7(.7) \\
7(.7) \\
7(.7)\end{array}$ & $\begin{array}{r}4(.4) \\
7(.7) \\
10(.9) \\
10(.9) \\
7(.7) \\
\end{array}$ \\
\hline $\begin{array}{c}\text { MPg09C } \\
" \\
" \\
\end{array}$ & $\begin{array}{l}2.7(15-50) \\
3-13(20-90) \\
5-10(35-70) \\
7.13(50-90)\end{array}$ & $\begin{array}{c}8(.7)^{*} \\
12(1) \\
\cdots\end{array}$ & $\begin{array}{r}8(.7)^{\prime \prime} \\
12(1) \\
12(1) \\
12(1) \\
\end{array}$ & $\begin{array}{c}8(.7) \\
12(1) \\
20(1.9) \\
20(1.9) \\
\end{array}$ & $\begin{array}{c}7(.7)^{\circ} \\
\cdots \\
10(.9) \\
\ldots .\end{array}$ & $\begin{array}{r}7(.7) \\
10(.9) \\
10(.9) \\
10(.9) \\
\end{array}$ & $\begin{array}{c}7(.7) \\
10(.9) \\
16(1.5) \\
16(1.5) \\
\end{array}$ \\
\hline $\begin{array}{r}\text { MP904A } \\
\text { (MP904A } \\
\text { [1401 } \\
\end{array}$ & $\begin{array}{l}7-13(50.90) \\
120 \mathrm{psi} \\
1 \mathrm{~m})\end{array}$ & & $\begin{array}{c}45(4.2) \\
(60)(5.8)\end{array}$ & $\begin{array}{c}45(4.2) \\
(6 U)(b .8)\end{array}$ & $\therefore$ & $\begin{array}{c}36(3.4) \\
(50)(4.7)\end{array}$ & $\begin{array}{l}36(3.4) \\
(50)(4.7)\end{array}$ \\
\hline \begin{tabular}{c} 
MPSOAB \\
$" 1$ \\
\hdashline \\
\end{tabular} & $\begin{array}{l}2.7(15.50) \\
3.13(20.90) \\
7.13(50.90) \\
\end{array}$ & $\begin{array}{c}20(1.9)^{*} \\
\ldots \\
\ldots \\
\end{array}$ & $\begin{array}{l}20(1.9)^{*} \\
30(2.8)^{*} \\
30(2.8)\end{array}$ & $\begin{array}{l}20(1.9) \\
30(2.8) \\
45(4.2) \\
\end{array}$ & $\begin{array}{l}\cdots \\
\ldots \\
\ldots \\
\end{array}$ & $\begin{array}{l}15(1.4)^{=} \\
25(2.3) \\
25(2.3) \\
\end{array}$ & $\begin{array}{l}15(1.4) \\
25(2.3) \\
31(2.9) \\
\end{array}$ \\
\hline MP903A & $3-13(20-90)$ & $\ldots$ & $8(.7)$ & $8(.7)$ & $\ldots$ & $7(.6)$ & $7(.6)$ \\
\hline
\end{tabular}

"2-Position Force Limitation

Electric \& Electronic Motor Damper Ratinys $\left(\mathrm{Ft}^{2}\right.$ of Damper)

\begin{tabular}{|l|c|c}
\cline { 2 - 3 } & \multicolumn{2}{c}{ Damper Rating } \\
\hline Motor (1 min. stroke) & 0640 \& D641 & D642 \& D643 \\
\hline M634, M734, M934 (35 lb-in.) & $15(1.4)$ & $12(1.1)$ \\
\hline M445, M745, M845, M945 (50 lb-in.) & $21(2)$ & $18(1.7)$ \\
\hline M644, M744, M944 (150 lb-in. 200 lb bearing limit) & $47(4.4)$ & $39(3.6)$ \\
\hline
\end{tabular}

NOTES:

1. Two position ratings are based on standard dampers requiring $5 \mathrm{lb}-\mathrm{in} . / \mathrm{ft}^{2}$ of closing torque and low leakage dampers requiring $6 \mathrm{lb}$-in. $/ \mathrm{ft}^{2}$ closing torque to properly close the damper.

2. Modulating ratings are based on $2 / 3$ of the above torques and 2 psi ( $15 \mathrm{kPa}$ ) maximum offset and are applicable throughout the performance range of damper intended.

3. $150 \mathrm{lb}$-in. Modutrol" motor sizing limited by $200 \mathrm{lb}$ bearing load limit. 


\section{Honeywell}

\section{Moduflow" Dampers}

Table 1 illustrates the maximum operator rating for various pneumatic and electric damper operators. By referring to this table the installer can determine which operator or how many operators are needed for a particular installation.

EXAMPLE: $A$ damper required for installation has an " $A$ " dimension of 120 inches $(3048 \mathrm{~mm})$, and a " $B$ " dimension of 78 inches $(1981 \mathrm{~mm})$. This damper has an equivalent area of 70 square feat $(6.5 \mathrm{sq} \mathrm{m})$. Checking the operator table you see that three MP9O4B pneumatic operators with a 3 to $13 \mathrm{psi}(.2$ to .9 barl spring range are needed to operate a multisection damper this size.

Although differences in damper design from one damper to another may not be obvious they are of utmost importance in terms of the performance and reliability you want. Through quality design, materials, and workmanship Honeywell Moduflow dampers provide you with highly efficient, low-leakage air flow control without sacrificing economy.

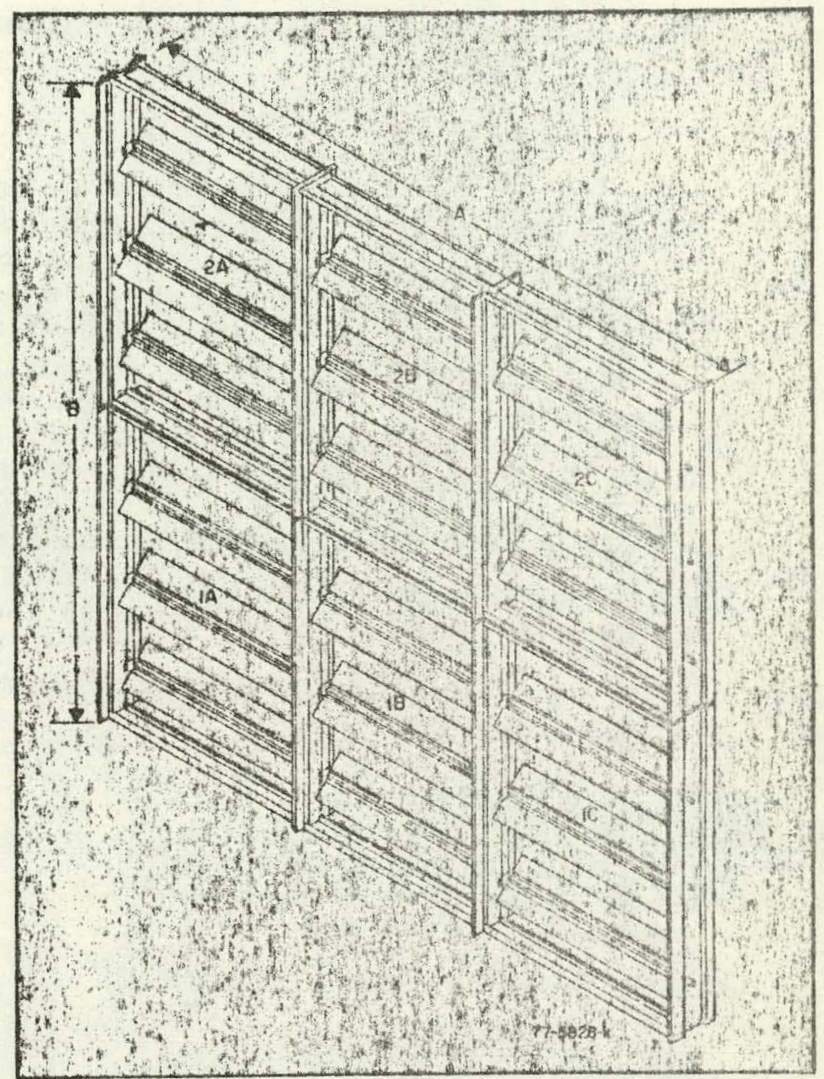

Fig. 11. 

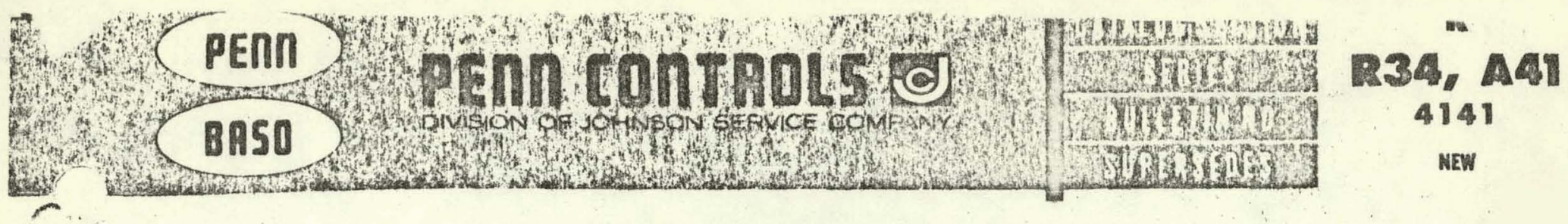

\section{series R34, A4IW \\ SOLID STATE DIFFERENTIAL TEMPERATURE CONTROLLER AND SENSOR}

For Solar Heating Applications

\section{APPLICATION}

The Series R34 differential temperature controller was designed for use on solar heating applications. It automatically turns on a circulating pump or blower to transfer hot liquid or air from the collector to the storage facility when a predetermined temperature differential is exceeded. The pump or blower is turned off when the medium temperature from the collector approaches the storage temperature. This controller is also for other differential temperature control applications.

The Type A41W temperature sensor is a nickel wire wound temperature element for use with the Series R34 controller. It is for temperatures up to $350^{\circ} \mathrm{F}\left(177^{\circ} \mathrm{C}\right)$ with a resistance of $1000 \mathrm{ohms} \pm 1 \%$ at $70^{\circ} \mathrm{F}\left(21^{\circ} \mathrm{C}\right)$. It has a temperature coefficient of approximately $3 \mathrm{ohms}$ per degree Fahrenheit.

\section{FEATURES}

- All solid state components.

- Easy to install and wire.

- Shielded wire not normally required.

- Accurate sensitive nickel wire sensing element.

\section{GENERAL DESCRIPTION}

The differential temperature controller has all solid state components and operates from two Type A41W precision nickel resistance temperature sensors. One sensor is located at the collector panel and the other in the storage facility.

The ourput triac is isolated from the control circuitry with an optically coupled isolator. The "isolated tab" output triac inherently provides an electrically insulated heat sink.

The Type R3 AAAB is open construction and monnts on four standoffs within the controlled equipment. Ex-

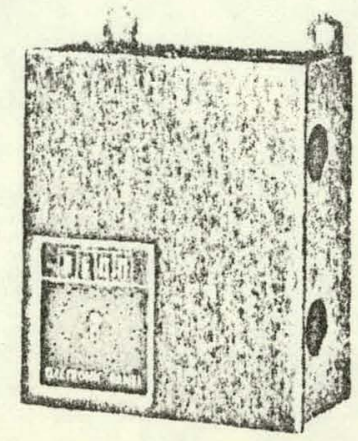

Fig. 2 - Type R34AAA controller.
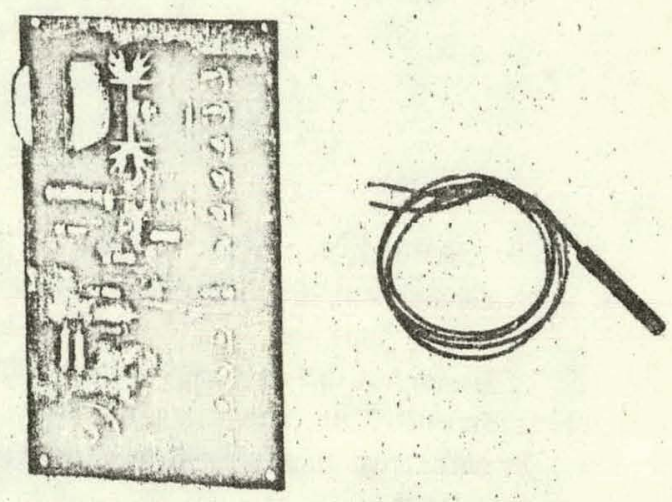

Fig. 1 - Type R34AAB controller and Type A4IW sensor.

ternal wiring is connected to identified screw terminals on a terminal strip. The high and low set points are set and sealed at the factory to the customers specifications. The Type R34AAA is supplied in a NEMA Type 1 enclosure.

The sensing elements mount directly to the collector pancl and in a bulb well in the storage tank on hot water systems. A well is not required for the storage sensor when the air storage system is used. The sensors have two 22" long \#18 AWG wire leads.

\section{SPECIFICATIONS}

\begin{tabular}{|c|c|c|c|}
\hline if Prodinet? & 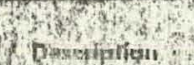 & $\begin{array}{l}\text { Tempecatura Diff } \\
\text { of }\end{array}$ & $\begin{array}{l}\text { prentiol Seftinge } \\
\text { CI }\end{array}$ \\
\hline 5) Number & 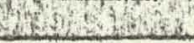 & Si Turrives. & i. Turnots. \\
\hline A4IW-1 & Sensor & - & - \\
\hline R34AAA-1 & $\begin{array}{c}\text { Controller in } \\
\text { NEMA Type I } \\
\text { Enclosure }\end{array}$ & $20 \pm 5(11 \pm 3)$ & $5 \pm 3(3 \pm 2)$ \\
\hline R34AAB-I & Controller & $20 \pm 5(11 \pm 3)$ & $5 \pm 3(3 \pm 2)$ \\
\hline
\end{tabular}

Type A4IW

Electrical Connections: 'Two 22" long \#18 AWG stranded wire leads.

Operating Temperature Ranges: $-40^{\circ}$ to $350^{\circ} \mathrm{F}$ $\left(-40^{\circ}\right.$ to $\left.177^{\circ} \mathrm{C}\right)$.

Reference Resistance: $1000 \mathrm{ohms}$ at $70^{\circ} \mathrm{F}\left(21^{\circ} \mathrm{C}\right)$.

Resistance Tolerance: $1 \%$ at $70^{\circ} \mathrm{F}\left(21^{\circ} \mathrm{C}\right)$.

Sensing Element: Temperature sensitive nickel , wound.

Temperature Coefficient: Positive at approximately 3 ohms per degree Fahrenheit. ( 5.4 ohms per degree Celsius.) 


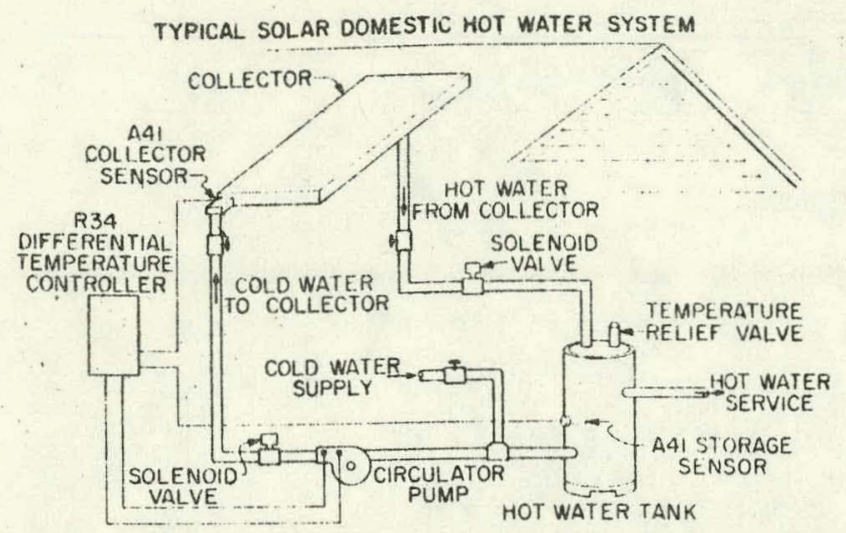

Fig. 3-Drawing of typical solar domestic hot water system.

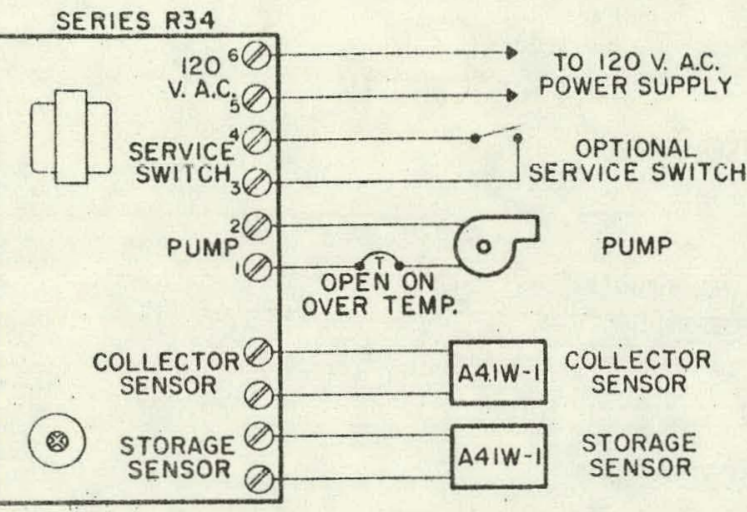

Fig. 4-Typical wiring diagram.

\section{Types R3AAAA, R34AAB}

Ambient Temperature: $0^{\circ}$ to $120^{\circ} \mathrm{F}\left(-18^{\circ}\right.$ to $\left.49^{\circ} \mathrm{C}\right)$. Maximum heat sink temperature is $194^{\circ} \mathrm{F}\left(90^{\circ} \mathrm{C}\right)$.

Electrical Connections: Identified terminal screw on terminal strip. See Fig. 5.
Electrical Load: 120 V. A.C., 2 amps. maximum.

Supply Voliage: 120 V. A.C.

\section{ACCESSORIES}

Bulb Wells For Type AaIW

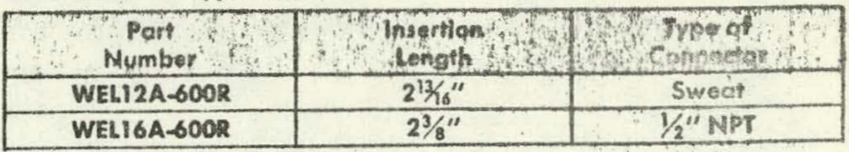

\section{SHIPPING WEIGHT}

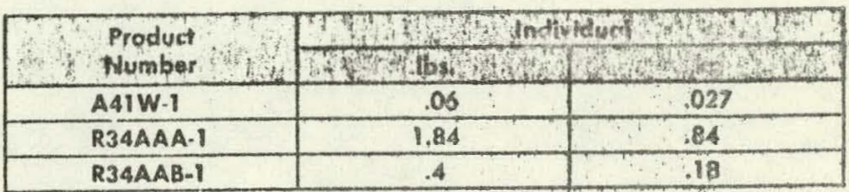

\section{REPAIRS AND REPLACEMENT}

Field repairs must not be made. Replacement units may be obtained from the nearest Penn Commercial Systems Wholesaler. When ordering a replacement controller or sensor, specify Product Number shown on the units.

For trouble-shooting procedure, see Series R34 Installation and Operation Instructions Form 996-94.

\section{ORDERING INFORMATION}

To order, specify:

1. Complete Product Number.

2. Bulb well Part Number for Type $A 41 W$, when required.

3. If set points other than shown in Bulletin are desired, write Customer Service.

\section{DIMENSIONS}

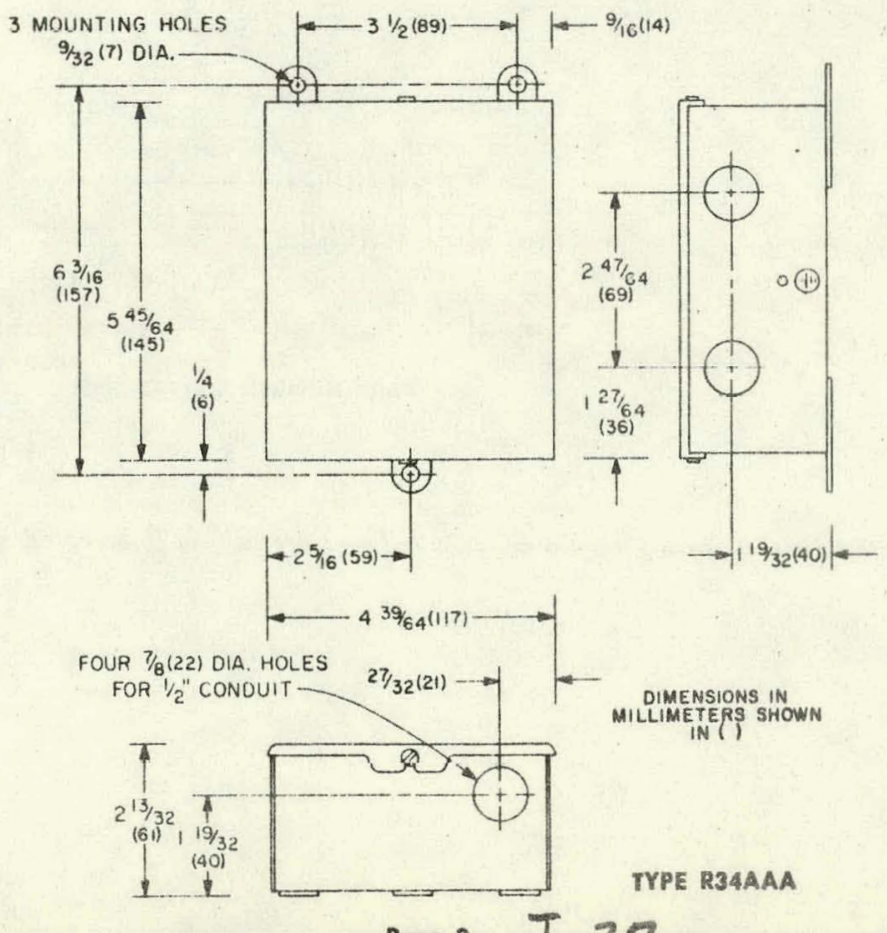



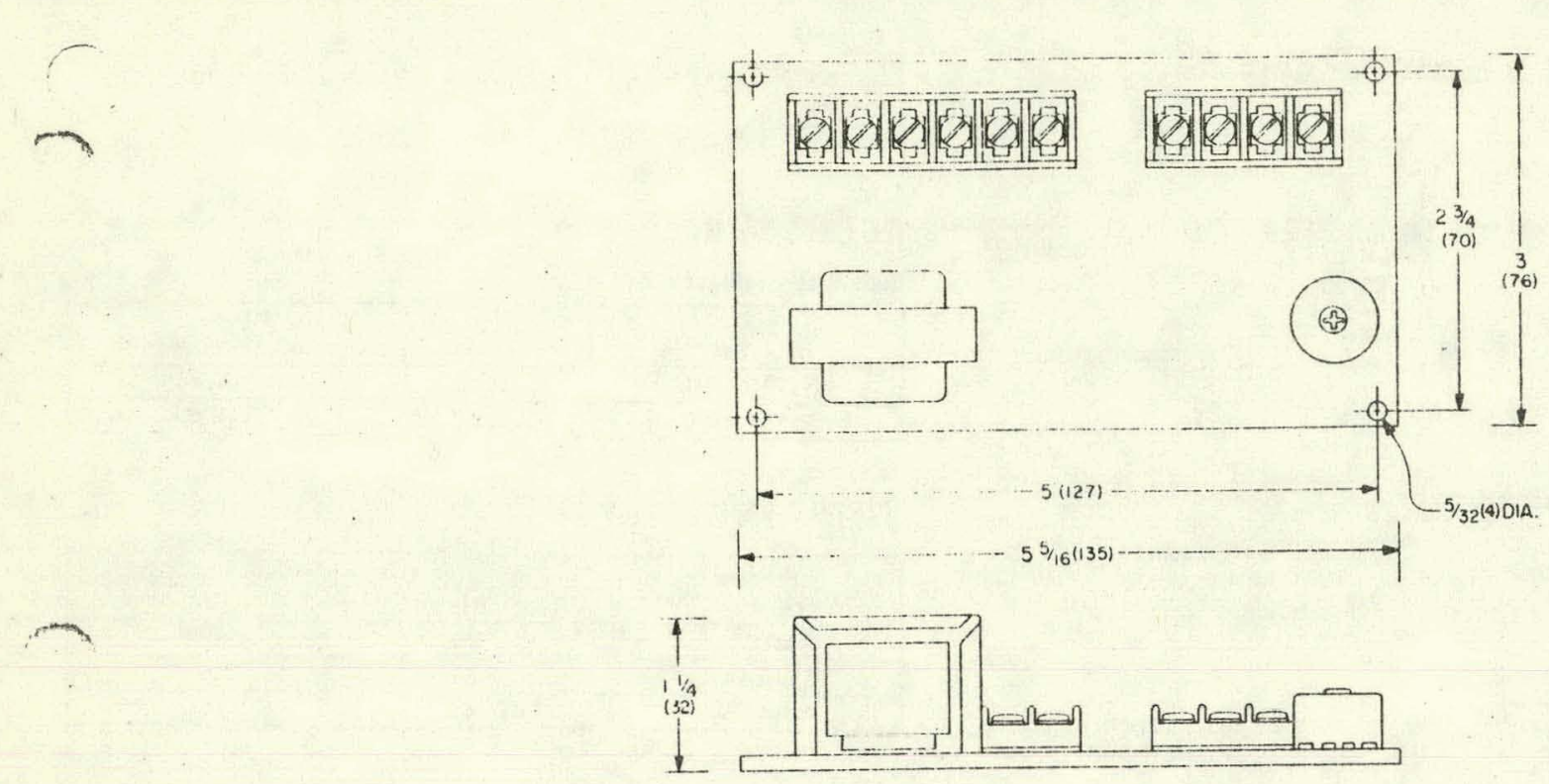

TYPE R34AAB
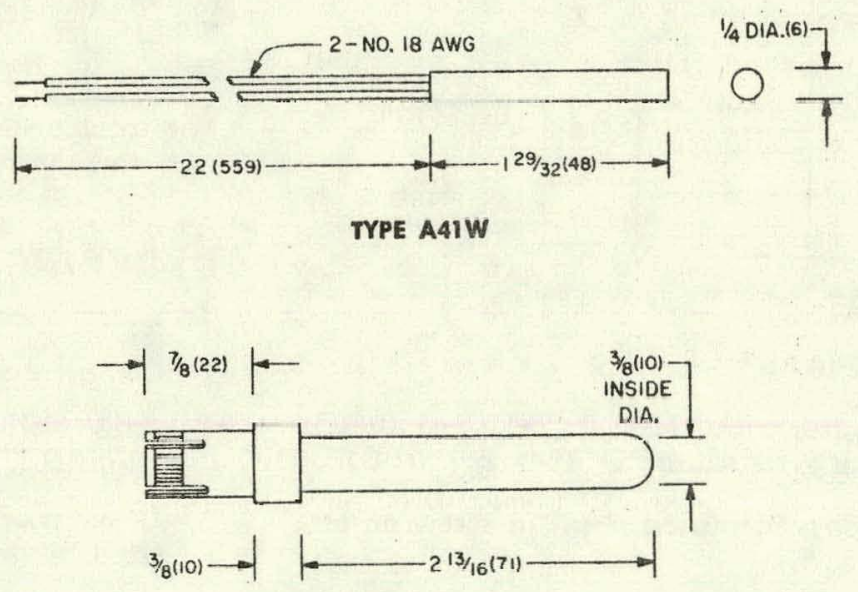

PART NUMBER WELIT2A-600R

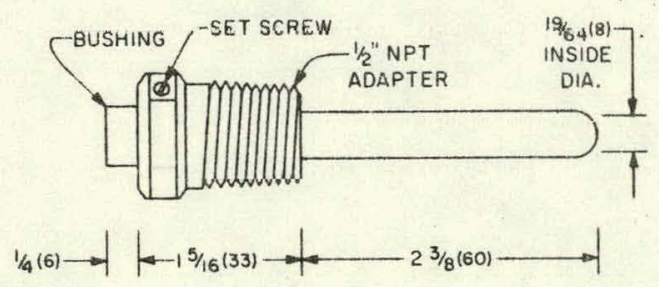

PART NUMBER WELIGA-600R

Performance specifications appearing berein are nominal and are subject to accepted manufacturing tolerances and application variables. 


\section{APPLICATION}

This differential temperature controller was designed for use on solar heating applications. It automatically turns on a circulating pump or blower to transfer hot liquid or air from the collector to the storage facility when a predetermined temperature differential is exceeded. The pump or blower is turned off when the medium temperature from the collector approaches the storage temperature. This controller can also be used for other differential temperature control applications.

\section{INSTALLATION}

Follow equipment manufacturer's instructions where available. If not available, proceed as follows.

\section{Locating and Mounting}

Locate the controller in any convenient, protected location near the controlled equipment. Under full load conditions the controller dissipates approximately 4 watts and must be mounted with adequate clearance around the device to allow convection cooling of the triac heat sink. Mount Type R34AAA by the three mounting lugs on the enclosure. Mount Type R34AAB un four standoffs.

Locate the controller where the ambient temperature does not exceed $120^{\circ} \mathrm{F}\left(49^{\circ} \mathrm{C}\right)$ or go below $0^{\circ} \mathrm{F}$ $\left(-18^{\circ} \mathrm{C}\right)$. The maximum heat sink temperature is $194^{\circ}$ $\mathrm{F}\left(90^{\circ} \mathrm{C}\right)$.

\section{Wiring}

CAUTION: Disconnect power supply before wiring and mounting connections are made to prevent electrical shock or possible damage to equipment.

All wiring must be in accordance with local regulations and the National Electrical Code.

Check rating of circularing pump or blower motor to be sure it does not exceed rating of the Series R34 con-

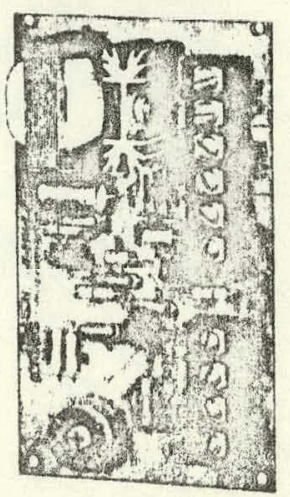

\section{SOLID STATE DIFFERENTIAL TEMPERATURE CONTROLLER}

INSTALLATION AND OPERATION INSTRUCTHONS

SERIES R34

FORM 996-94-1

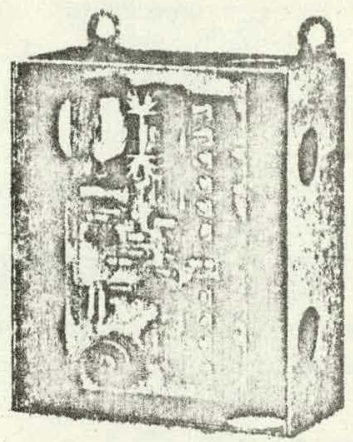

Fig. 1 - Type R34AAA controller with cover removed.

troller. If rating of motor exceeds the Series $\mathbb{R} 34$ rating, install an adequately rated relay or contactor to operate motor.

Make wiring connections to identified screw terminals on the barrier strip. The sensor leads should be at least No. 18 wire for lengths up to $50 \mathrm{ft}$. No. 14 wire should be used for runs up to $250 \mathrm{ft}$. Splices should be made with wire nuts or by soldering and taping.

CAUTION: Make all wiring connections and check for correctness before applying power. Improper wiring may cause permanent damage.

\section{ADJUSTMENTS}

This controller is set at the factory and cannot be adjusted in the field.

\section{CHECKOUT PROCEDURE}

When components are installed and wiring is completed recheck the wiring and apply power.

Before leaving the installation, a complete operating cycle should be observed to see that all components are functioning properly.

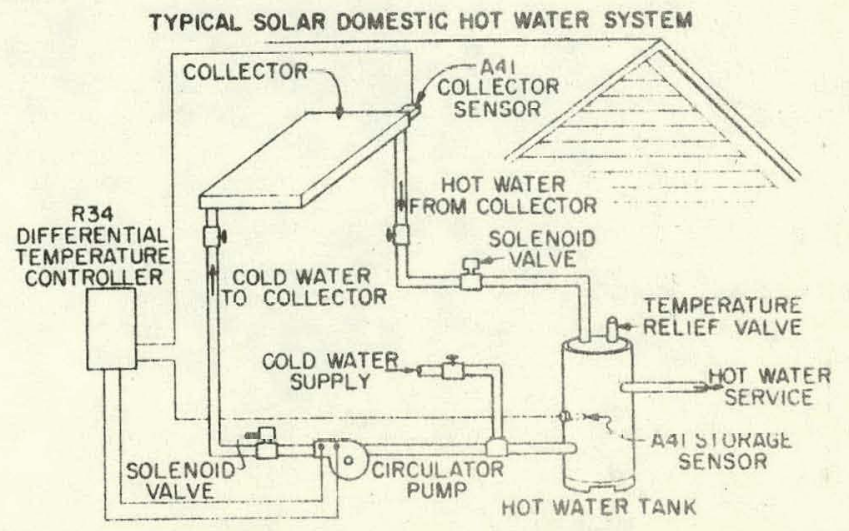

Fig. 2 - Type R3AAAB controller. 
SERIES R34.

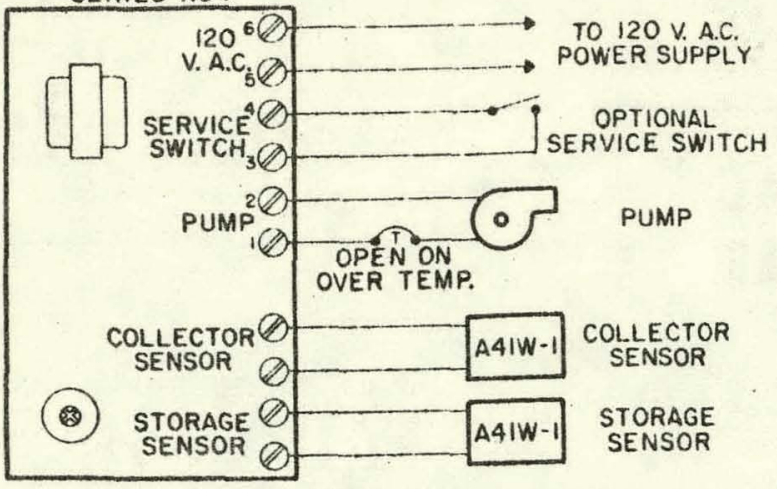

Fig. 4-Typical wiring diagram.

\section{TROUBLE-SHOOTING PROCEDURE}

If circulating device (pump or blower) fails to energize when conditions indicate it should be running, proceed as follows:

1. Use a thermometer and check to be sure the proper differential does exist.

2. Check for proper voltage ( 120 V. A.C. ) supply to terminals 5 and 6 , see Figure 4 .

3. If Steps 1 and 2 check all right, disconnect the collector sensor leads from the Series R34 controller. This simulates a very high collector panel temperature and the pump (blower) should energize.
Another way to test this function would be to reconnect the collector sensor and short circuit the storage sensor. This simulates an extremely low storage temperature and the pump (blower) should energize.

If this step energizes the pump, a defective collector sensor and/or storage sensor is indicated. Refer to sensor checkout instructions in Series A41 instruction Form 996-104.

4. If the Type A41W sensors are operational per Step 3 , short circuit terminals 3 and 4 for the manual override and if the pump (blower) energizes, a defective manual override switch is indicated. Check wiring to switch. Replace the switch if bad.

CAUTION: Use extreme care. These terminals are line voltage and could cause electrical shock.

5. If short circuiting the service switch terminals does not encrgize the pump (blower), a defective Series R34 is indicated and should be returned to the factory for repair.

\section{REPAIRS AND REPLACEMENT}

Field repairs must not be made. Replacement units may be obtained from the nearest Penn Commercial or Systems Wholesaler. When ordering a replacement controller, specify Product Number shown on the controller. 


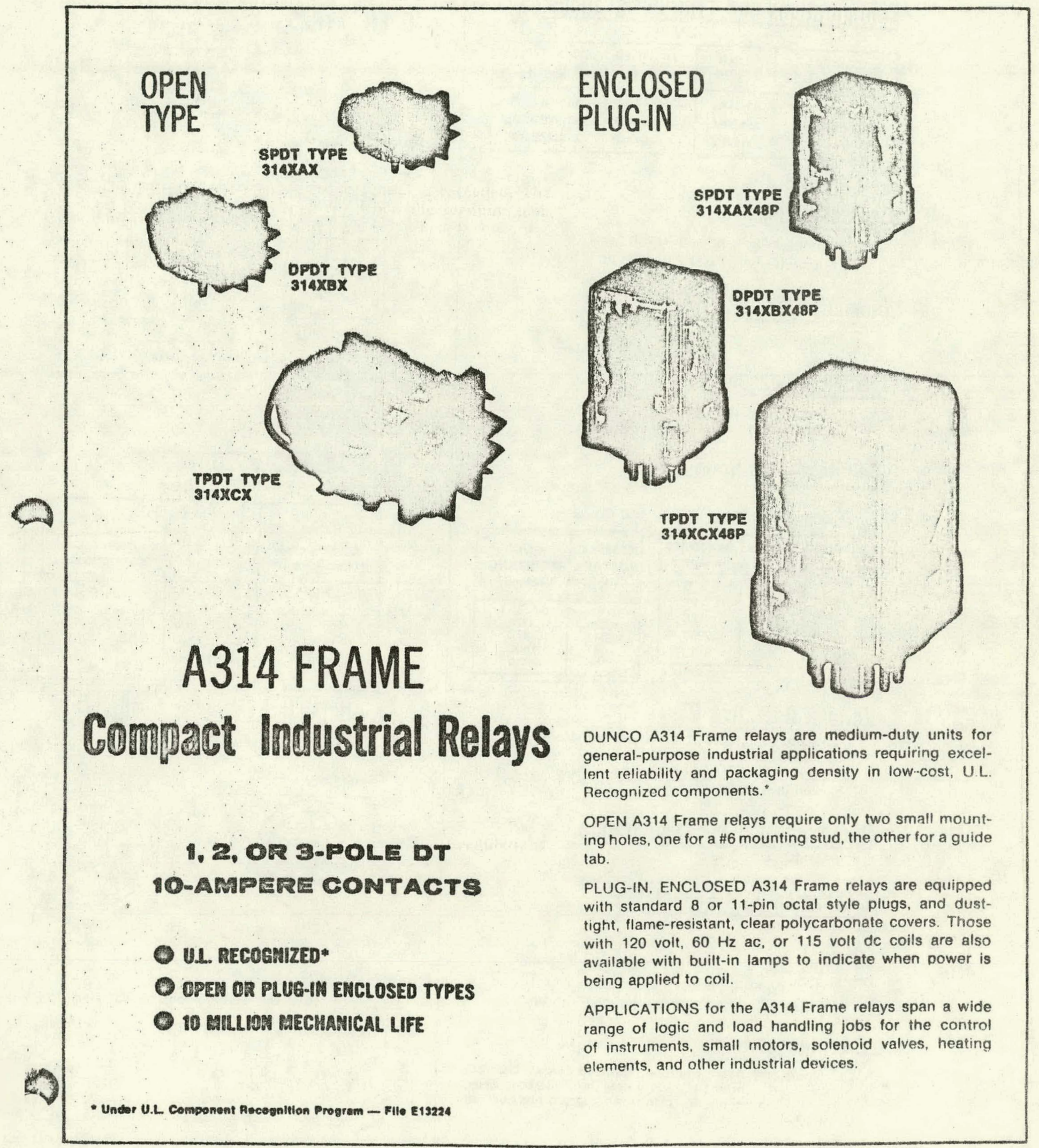




\section{S.D CONTROL RELAYS • General Purpose}

\section{Typical Specifications: A314 Frame Relays}

\section{Configurations and Type Designations:}

\begin{tabular}{|c|c|c|c|}
\hline \multirow{2}{*}{$\begin{array}{c}\text { CONTACT } \\
\text { CONFIGURATION }\end{array}$} & \multirow{2}{*}{$\begin{array}{l}\text { OPEN } \\
\text { TYPES }\end{array}$} & \multicolumn{2}{|c|}{ ENCLOSED, PLUG-IN TYPES } \\
\hline & & Basic & with Neon Lamp \\
\hline SPDT & A314XAX & A314XAXXABP & A31AXAX48PL \\
\hline DPDT & A314XBXX & A314XBX $48 \mathrm{P}$ & А $314 \times B \times 48 P L$ \\
\hline TPOT & A314XCX & A.314XCX48P & A314XCXEBPL \\
\hline
\end{tabular}

\section{Contact Ratings:}

10 amperes or $1 / 6 \mathrm{hp}$ at 120 volts ac.

5 amperes or $1 / 3 \mathrm{hp}$ at 240 volts ac.

Dielectric Strength:

1500 volts ac for 1 minute

\section{Electrical Spacings:}

' 116 " minimum through air; $1 / \mathrm{s}$ " minimum over surfaces between current-carrying parts.

Coil Data-continuous duty

\begin{tabular}{|} 
AC Colls, $50 / 60 \mathrm{~Hz}$ \\
\begin{tabular}{|c|c|r|}
\hline $\begin{array}{c}\text { VOLTAGE } \\
\text { (Nominal) }\end{array}$ & $\begin{array}{c}\text { Current } \\
\text { in mA }\end{array}$ & $\begin{array}{c}\text { Aesistance } \\
\text { in Ohms }\end{array}$ \\
\hline 6 & 335. & 6 \\
12 & 168. & 21 \\
24 & 83. & 85 \\
120 & 17.5 & 2250 \\
210 & 875 & 9110 \\
\hline
\end{tabular}
\end{tabular}

\begin{tabular}{|c|c|}
\hline DC COILS & \\
\begin{tabular}{|c|c|}
\hline NOMINAL \\
VOLTAGE \\
(dC)
\end{tabular} & $\begin{array}{c}\text { DC } \\
\text { RESISTANCE } \\
\text { (Ohms) }\end{array}$ \\
\hline 6 & 32.1 \\
12 & 120 \\
24 & 472 \\
48 & 1800 \\
115 & 10000 \\
\hline
\end{tabular}

\section{Voltage Operating Range:}

$A C$ relays operate at $85 \%$ and withstand $110 \%$ of nominal voltage.

DC relays operate at $80 \%$ and withstand $110 \%$ of nominal voltage.

Operating Ambient Temperature: $-45^{\circ} 10+50^{\circ} \mathrm{C}$.

\section{Mechanical Life Expectancy:}

10 million operations, minimum.

Weight:

Open types-2 2 ounces, approx.

Enclosed, plug-in types- -3 ounces, approx.

\section{U.L. Recognition:}

Open and basic enclosed plug-in relays are recognized under the Underwriters' Laboratories Inc. Component Recognition Program-file number E13224.

\section{ORDEPING IMFORMATION:}

Always specify relay type number, and coil voltage and frequency.

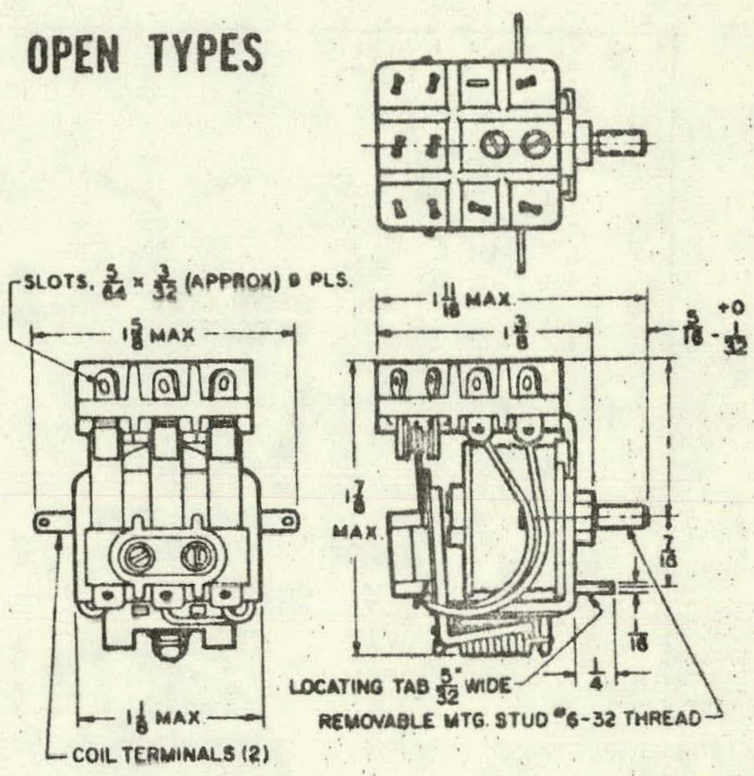

\section{PLUG-IN ENCLOSED TYPES}
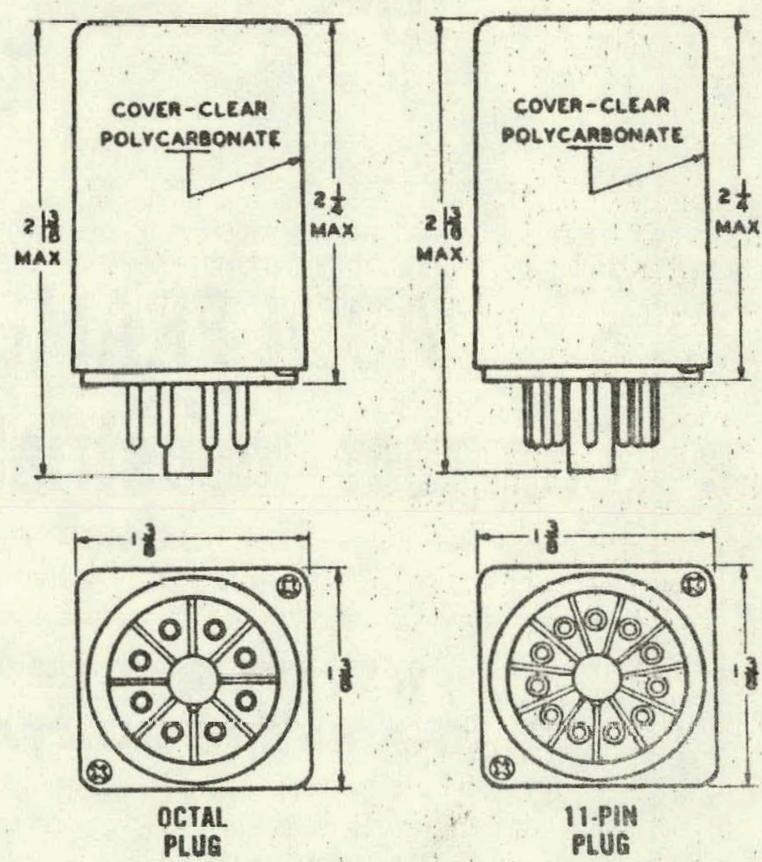

INTERNAL WIRING-Terminal Plug View
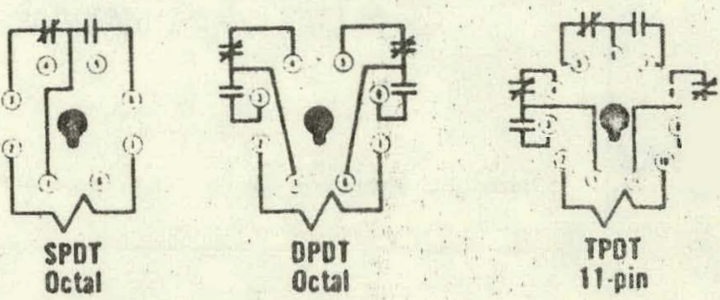


\section{RECFIVED:AAR 2 IOT7}

- Momeywell

THESE THERMOSTATS AND SUBBASES PROVIDE LOW VOLTAGE CONTROL OF MULTISTAGE HEATING AND COOLING SYSTEMS INCLUDING HEAT PUMP SYSTEMS.

口 T872 Thermostat requires a Q672 Subbase.

Q Q672 Subbase provides system and fan switching, wiring terminals and mounting base for T872 Thermostat.

口 T872 Thermostat has silent dust-free mercury switches operated by coiled bimetal elements.

Q Q672 Subbase mounts on wall or horizontal outlet box.

- Adapter plate available for mounting Q672 Subbase on vertical outlet box.

D Heat anticipator(s) are adjustable; cooling anticipator(s) are fixed.

D External levers and scale for temperature setting located on top of thermostat case.

- Cover thermometer on all T872 Thermostat models.

$\square$ Locking cover and locking lever screws available for T872 Thermostats.

N.J.

$9.75(.125)$
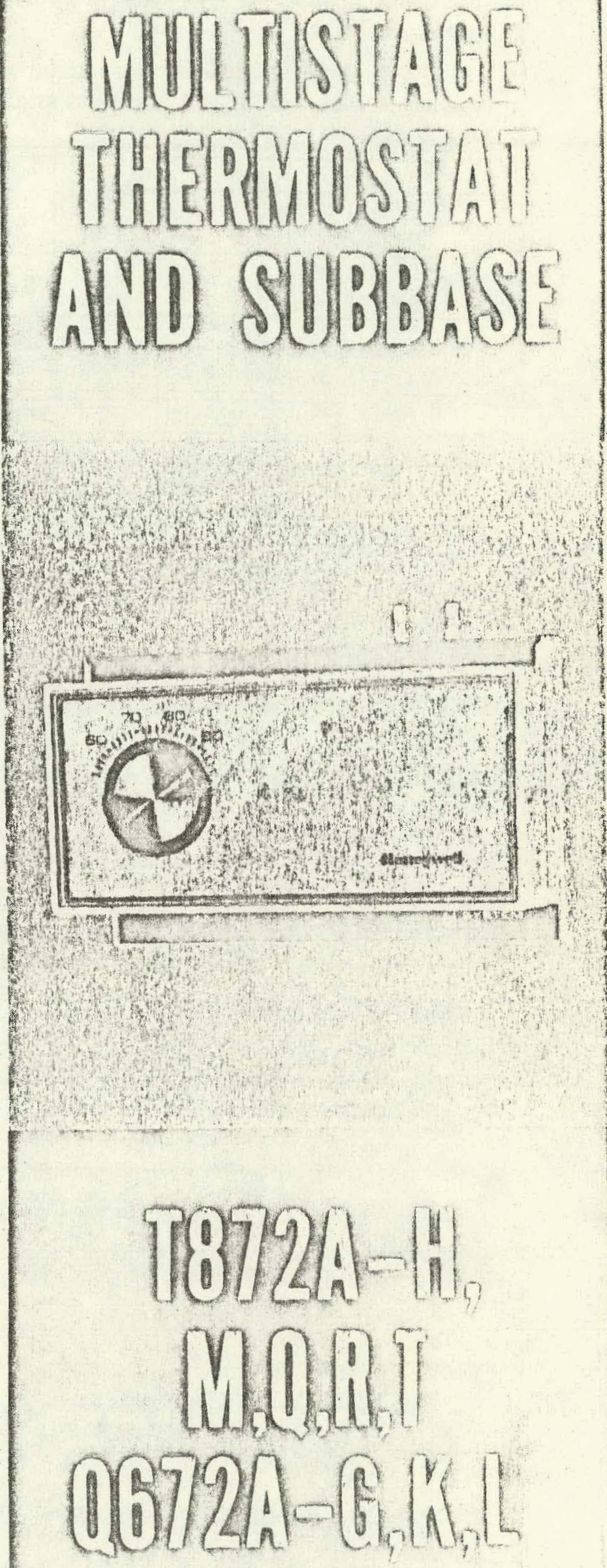

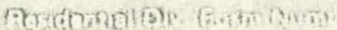




\section{TRADELINE MODELS}

Tradeline models are selected and packaged to provide ease of stocking, ease of handling, and maximum replacement value.

T872 Thermostat Tradeline models provide one or 2 staye heat and/or cool operation as shown in the chart below.

\begin{tabular}{c|c|c|c|c|c|c}
\hline T872 & A & B & C & D & E & F \\
\hline $\begin{array}{c}\text { HEATING } \\
\text { STAGES }\end{array}$ & 1 & 1 & 2 & 2 & - & 2 \\
\hline $\begin{array}{c}\text { COOLING } \\
\text { STAGES }\end{array}$ & 1 & 2 & 1 & 2 & 2 & - \\
\hline
\end{tabular}

O672 switching subbase Tradeline models provide system and fan switching as listed.

\begin{tabular}{c|c|c}
\hline \hline Q672 & SYSTEM & FAN \\
\hline A & Heat-Auto-Cool & Auto-On \\
\hline B & Heat-Off-Cool & Auto-On \\
\hline E & Off-Heat-Auto-Cool & Auto-On \\
\hline
\end{tabular}

\section{TRADELINE FEATURES:}

- Tradeline package with cross reference label and special instruction sheet.

- T872A and D models with adjustable temperature locking stops.

- All Tradeline T872 models are supplied with locking lever and locking cover accessories.

- All Tradeline T872 models include 130821A Adapter Plate Assembly for mounting T872. Q672 on a vertical outlet box.

- All Tradeline thermostat models are compatible with all Tradeline switching subbase models.

MODELS: See Table 1.

ELECTRICAL RATING: 24 to $30 \mathrm{~V}$ ac.

SWITCHING: Coiled bimetal elements operate mercury switches.

TEMPERATURE ADJUSTMENT: Heating and cooling setting levers, with common scale located on top of thermostat base. Common lever for heating and cooling on T872R, 1 cooling lever on T872E, and 1 heating lever on $\mathrm{T} 872 \mathrm{~F}$.

TEMPERATURE SCALE RANGE: 44 to $86 \mathrm{~F}$. Scale is marked every $2 \mathrm{~F}$ and labeled $50,60,70$ and $80 \mathrm{~F}$.

THERMOMETER RANGE: 52 to $98 \mathrm{~F}$.

CHANGEOVER DIFFERENTIAL: 3 F minimum between heating and cooling. Levers may be set apart for greater separation.

\section{T872 THERMOSTATS}

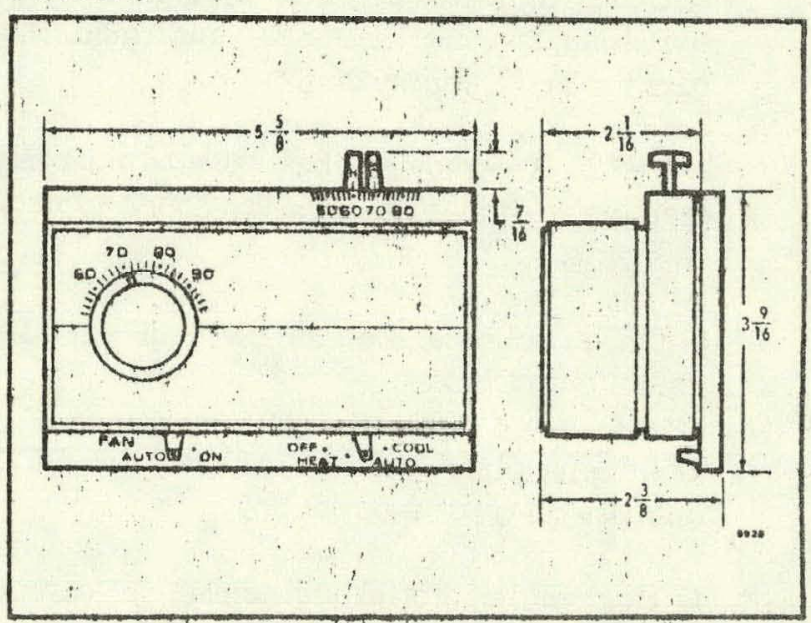

FIG. 1-DIMENSIONS OF T872 THERMOSTAT MOUNTED ON OG72 SUBBASE.

(continued on page 3 )

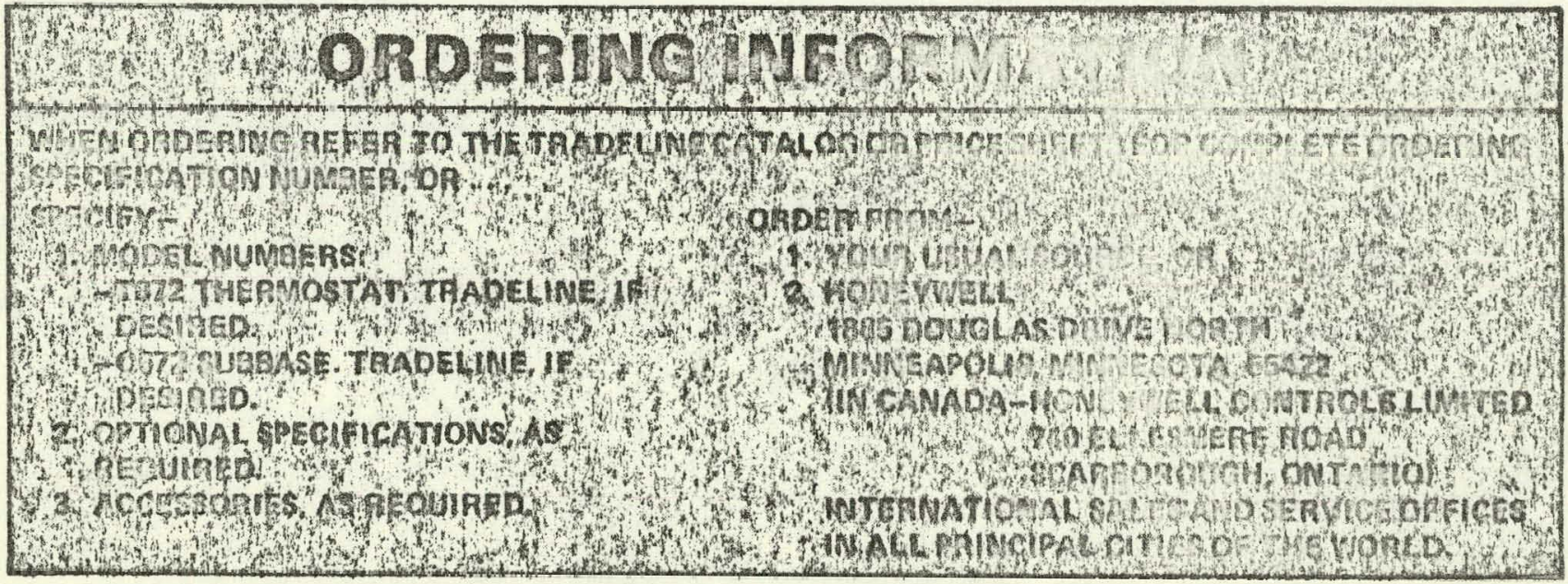


INTERSTAGE DIFFERENTIAL: I $\mathrm{F}$ between heating or cooling stages.

FINISH: Silver bronze.

MOUNTING MEANS: T872 Thermostat mounts on Q672 Subbase. Subbase mounts horizontally on wall or outlet box. Mounts on vertical outlet box with optional 130821 A Adapter Plate Assembly.

OPTIONAL SPECIFICATIONS (T872 only):

1. Locking cover and locking lever.

2. Nonadjustable factory added stop. Limits heating set point to $75 \mathrm{~F}$ maximum, cooling set point to $75 \mathrm{~F}$ minimum.

3. Customer personalization.

4. Centigrade scale.

5. Fast cycling on heating stage(s) for electric heat applications.
6. Adjustable locking temperature stops.

7. Thermostat cover less thermometer.

ACCESSORIES:

1. Locking cover and locking lever assembly, Part No. $133627 \mathrm{AA}$; includes two No. $4 \times 1 / 4$ panhead screws to lock set point levers plus screws and Allen wrench for locking cover.

2. Universal thermostat guard-

-Part No. 133722A, clear plastic cover and beige plastic mounting base;

-Part No. 133722D, clear plastic cover and clear plastic "ring type" mounting base. Thermostat need not be removed from wall to install guard;

-Part No. 133723A, beige plastic cover and beige plastic mounting base.

TABLE 1-T872 THERMOSTAT SPECIFICATIONS

\begin{tabular}{|c|c|c|c|c|c|c|c|c|c|}
\hline \multirow{3}{*}{$\begin{array}{l}\text { MODELS AND } \\
\text { OPTIONS }\end{array}$} & \multirow{3}{*}{$\begin{array}{c}\text { AE- } \\
\text { PLACES }\end{array}$} & \multirow{3}{*}{$\begin{array}{c}\text { APPLICATION } \\
\text { STD OR } \\
\text { HT PUMP } \\
\end{array}$} & \multirow{2}{*}{\multicolumn{3}{|c|}{ SYSTEM STAGES }} & \multicolumn{4}{|c|}{ ANTICIPATION } \\
\hline & & & \multirow{2}{*}{ HEAT } & & & \multicolumn{2}{|c|}{$\operatorname{HTG}(A D J)$} & \multicolumn{2}{|c|}{ COOLING (FIXED) } \\
\hline & & & & $\mathrm{COOL}$ & OTHEA & STAGE I & STAGE2 & STAGE 1 & STAGE ? \\
\hline \multirow{4}{*}{$\begin{array}{c}\text { T872A - Standard and Tradeline } \\
\text { - } 75 \mathrm{~F} \text { scaleplate stop } \\
\text { w/locking cover } \\
\text { - Adj heater set .4 amp } \\
\text { - Adjustable locking tem- } \\
\text { perature stops }(\mathrm{T} / \mathrm{L}) \\
\end{array}$} & \multirow{4}{*}{ T870A } & STD & 1 & 1 & - & $0.1-\$ .2 \mathrm{~A}$ & & Q.1.5A & \\
\hline & & STD & 1 & 1 & - & $0.1-1.2 \mathrm{~A}$ & & $0-1.5 \mathrm{~A}$ & - \\
\hline & & STD & 1 & 1 & - & $0.1-1.2 \mathrm{~A}$ & & $0-1.5 \mathrm{~A}$ & - \\
\hline & & STD & 1 & 1 & - & $0.1-1.2 \mathrm{~A}$ & - & $0-1.5 A$ & $\rightarrow$ \\
\hline \multirow{2}{*}{$\begin{array}{c}\text { T872B - Standard and Tradeline } \\
\text { - Adj heater set .4 amp } \\
\end{array}$} & \multirow{2}{*}{ T870B } & STD & 1 & 2 & - & $0.1-1.2 \mathrm{~A}$ & - & $0-1.2 A$ & $0.1 .0 \mathrm{~A}$ \\
\hline & & STD & 1 & 2 & - & $0.1-1.2 \mathrm{~A}$ & - & $0-1.2 \mathrm{~A}$ & $0.1 .0 \mathrm{~A}$ \\
\hline \multirow{3}{*}{$\begin{array}{c}\text { T872C - Standard and Tradeline } \\
-75 F \text { scaleplate stop } \\
\text { w/locking cover } \\
\text { - Fast cycling } \\
\end{array}$} & \multirow{3}{*}{ T870C } & STD & 2 & 1 & - & $0.1-1.2 \mathrm{~A}$ & $0.1-1.2 \mathrm{~A}$ & $\mathrm{C}-1.5 \mathrm{~A}$ & - \\
\hline & & STD & 2 & 1 & - & $0.1-1.2 A$ & $0.1 \cdot 1.2 \mathrm{~A}$ & $0.1 .5 \mathrm{~A}$ & - \\
\hline & & Elec Heat & 2 & 1 & - & $0.12-0.6 \mathrm{~A}$ & $0.12-0.6 \mathrm{~A}$ & $0.1 .5 \mathrm{~A}$ & - \\
\hline \multirow{2}{*}{$\begin{array}{c}\text { T872D - Standard and Tradeline } \\
\text { - Adjustable locking tem- } \\
\text { perature stops (T/L) }\end{array}$} & \multirow[b]{2}{*}{ T870D } & STD & 2 & 2 & - & $0.1-1.2 \mathrm{~A}$ & $0.1-1.2 \mathrm{~A}$ & $0.1 .2 A$ & $0.1 .0 \mathrm{~A}$ \\
\hline & & STD & 2 & 2 & - & $0.1-1.2 \mathrm{~A}$ & Q.1-1.2A & $0.1 .2 A$ & $0-9.0 \mathrm{~A}$ \\
\hline T872E - Standard and Tradalina & TR7nF & 2-Stage Cool & - & 2 & - & - & - & 0.9 .21 & $01.0 \mathrm{~A}$ \\
\hline \multirow{3}{*}{$\begin{array}{c}\text { T872F - Standard and Tradoline } \\
\text { - Locking cover } \\
\text { - Fast cycling }\end{array}$} & \multirow{3}{*}{ T870F } & 2-Stage Heat & 2 & - & - & $0.1+1.2 \mathrm{~A}$ & $0.1-1.2 \mathrm{~A}$ & - & - \\
\hline & & 2-Stage Heat & 2 & - & - & $0.1-1.2 \mathrm{~A}$ & $0.1-1.2 \mathrm{~A}$ & - & - \\
\hline & & Elec Heat & 2 & - & - & $0.12-0.6 \mathrm{~A}$ & $0.12-0.6 \mathrm{~A}$ & - & - \\
\hline T872G - Fast cycle stage 2 heat & T870G & Ht Pump & 2 & 1 & 10 & $0.1 .0 \mathrm{Ab}$ & $0.12 \cdot 0.6 \mathrm{~A}$ & - & $0.1 .0 \mathrm{~A}$ \\
\hline T372H-Use with $0672 \mathrm{C}$ & New & Ht Pump & 1 & 1 & 19 & $0-0.8 A^{b}$ & - & - & $0-0.8 \mathrm{~A}$ \\
\hline $\begin{array}{l}\text { TB72M-Motel heating-cooling } \\
\text { application (Requires } \\
\text { manual changeover } \\
\text { remote switching) } \\
\end{array}$ & T870M & $\begin{array}{c}\text { Remote } \\
\text { Panel } \\
\text { Switching }\end{array}$ & 1 & 1 & $1 \mathrm{c}$ & $0.1 \cdot 1.2 \mathrm{~A}$ & - & $0-1.5 A$ & - \\
\hline T8720 - Night setback heating & $\mathrm{T} 870 \mathrm{Q}$ & STD & 1 & - & $1^{t}$ & $0.1 \cdot 1.2 \mathrm{~A}$ & - & - & - \\
\hline T872R Standard & T870ח & Ht Pump ${ }^{\text {A }}$ & 2 & 1 & 10 & $0.1 .5 \mathrm{~A}^{5}$ & - & $0.1 .5 \mathrm{~A}$ & - \\
\hline T872T - Representative model & New & STD-Vent Stage & 1 & 2 & 19 & $0.1-1.2 \mathrm{~A}$ & - & $0-1.0 \mathrm{~A}$ & 0.1 .0 \\
\hline
\end{tabular}

a Changeover stage-operates with cooling.

bFixed voltage type anticipation.

CNonadjustable heating changeover stage set at $60 \mathrm{~F}$.

dChangeover stage-operates with heating.

e Manual changeover stage-use $Q 672 B, L$ subbase.

$f_{\text {Night setback. }}$

gVentialting stage. (See Fig. 10.) 
Q672

B3ASES

TABLE 2-Q672 SUBBASE SPECIFICATIONS

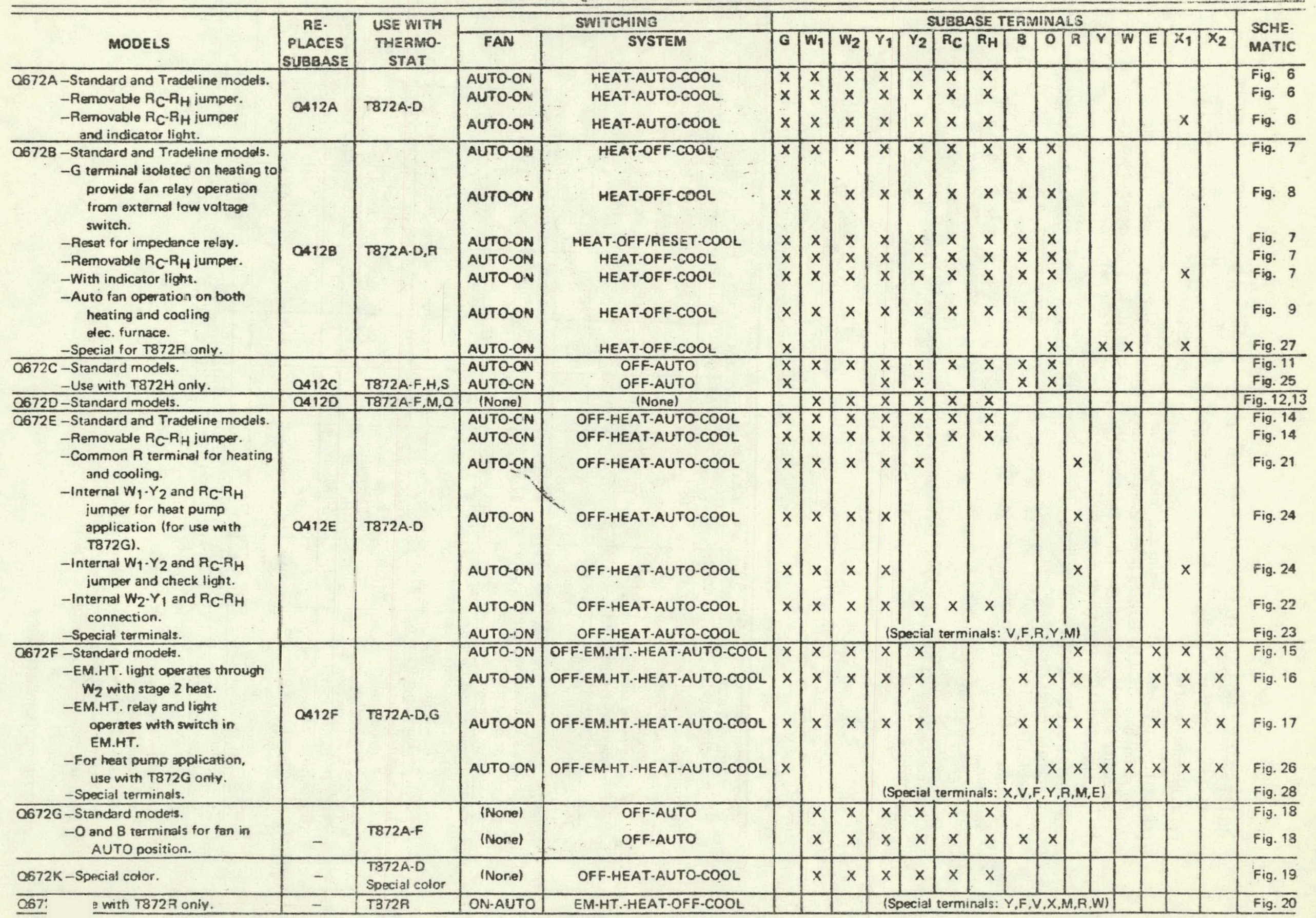


ELECTRICAL RATING:

Switch contacts $-2.5 \mathrm{amp}$ at $30 \mathrm{~V}$ ac (7.5 amp inrush). Malfunction light (optional) -24 to $30 \mathrm{~V}$ ac.

SWITCHES: Two snap-acting switches, operated by levers. Switch position is shown on scaleplate.

MOUNTING: Designed to mount horizontally on an outlet box or wall. Adapter plate assembly available for mounting on a vertical outlet box (see Accessories).

FINISH: Silver bronze,

DIMENSIONS (inches): $3.9 / 16$ high; $5.5 / 8$ wide; $5 / 16$ deep (see Fig. 1).

OPTIONAL SPECIFICATIONS (Q672 only):

1. Malfunction indicator light with replaceable bulb available on all models. Indicator can show FILTER, CHECK, or EM. HT. (emergency heat). Specify indication when ordering.

2. Jumper between $R_{C} \cdot R_{H}$ for common heatingcooling transformer. Jumper is field removable.

3. System switching marked HEAT-OFF/RESET-
COOL for systems requiring impedance relay reset Available on Q672B only.

4. " $G$ " terminal isolated on heating to provide fan relay operation from external low voltage fan switch (Q672B only).

5. Auto fan operation on both heat and cool (Q672B only).

ACCESSORIES:

1. Adapter plate assembly, Part No. $130821 \mathrm{~A}$, for mounting on vertical outlet box. Assembly includes adapter ring and cover plate.

2. Adapter plate assembly, Part No. 130821B, for covering old thermostat marks on wall. Cover plate only

3. Indicator replacement bulb, Part No. 129571.

4. Field addable indicator light assembly, Part No. 135734A. Assembly includes retainer plate, 2 selftapping screws, light bulb with 2-3/4 inch leadwires with spade terminals and lenses. The Q672 lenses indicate FILTER, CHECK or EM. HT.

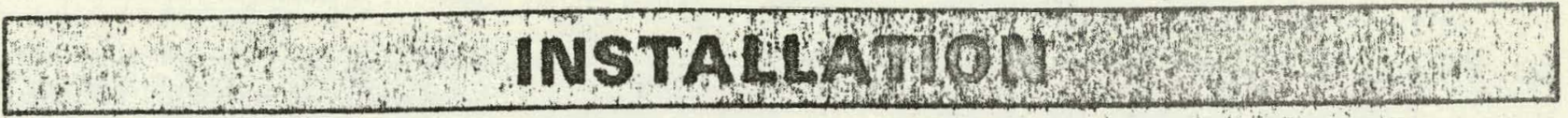

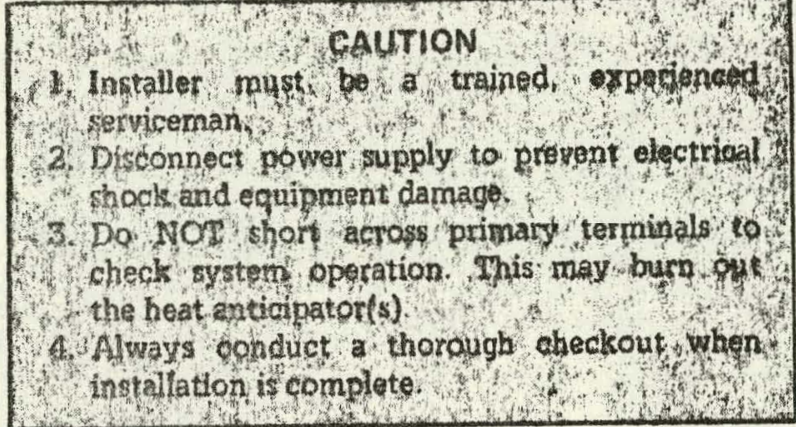

\section{LOCATION}

Locate the thermostat and subbase about 5 feet above the floor on an inside wall where there is good natural air circulation and where the thermostat will be exposed to average room temperatures. Avoid loca. tions behind curtains, in corners, alcoves, or in drafty areas. Avoid sources of heat or cold such as air ducts, water pipes, and electrical appliances.

\section{SUBBASE MOUNTING}

The subbase is designed for mounting on a wall or horizontal outlet box. (Adapter assembly, Part No. $130821 \mathrm{~B}$, with cover plate only is available for covering wall marks from old thermostat.) An adapter assembly, Part No. 130821 A, with adapter ring and cover plate is available for mounting on a vertical outlet box. To mount subbase, proceed as follows:

1. At the location selected, prepare an opening for the thermostat wires.

2. Run low voltage thermostat wires to the location, and pull about 4 inches through the wall opening.

NOTE: It is recommended that color-coded thermostat cable be used to facilitate proper wiring.
3. If mounting the subbase on vertical outlet box (Fig. 2), install the adapter ring with the 2 screws provided.

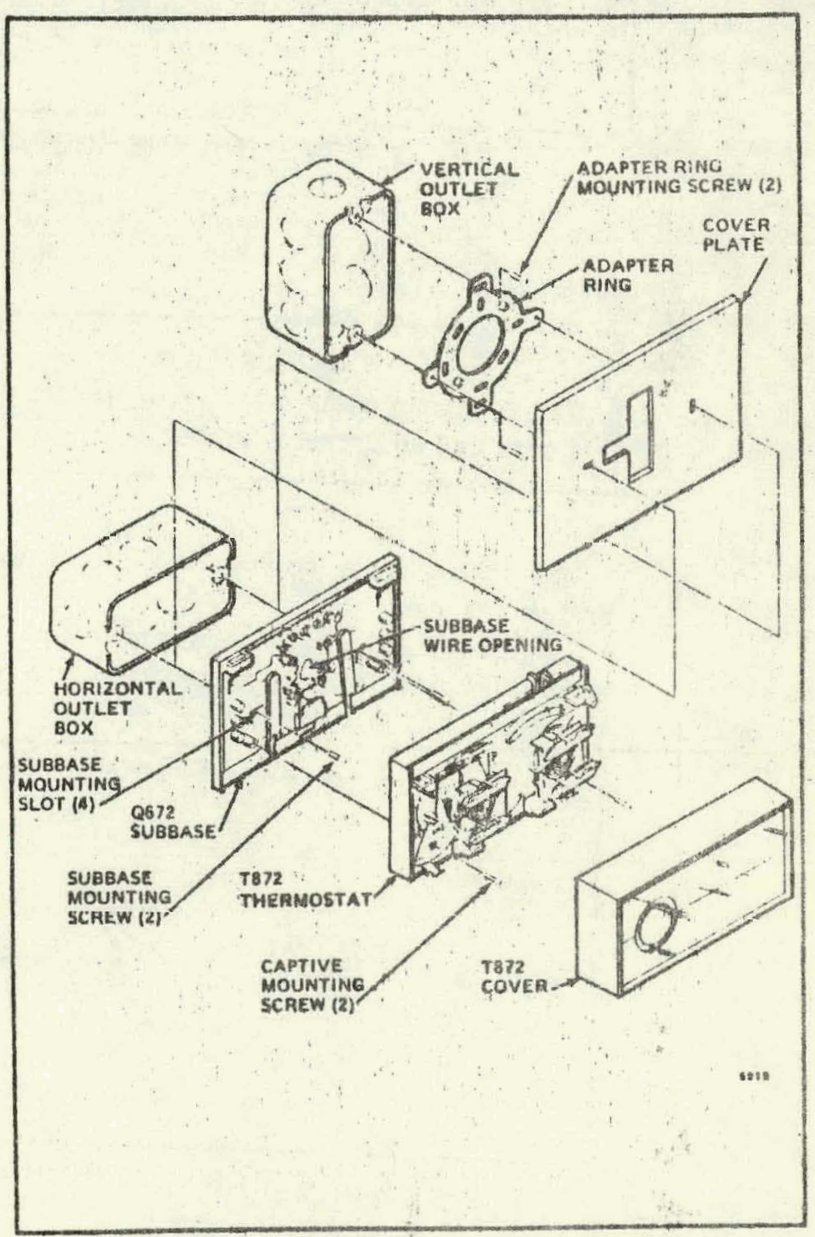

FIG. 2-INSTALLATION OF Q672 SUBBASE ON QUTLET BOX. 
4. Pull thermostat cable through cover plate (if used) and subbase opening. Secure the cover plate and subbase with the 2 screws provided, but do not tighten.

\section{IMPORTANT}

Thermostats are calibrated at the factory using subbases mounted at true level. Inaccurate subbase leveling will cause thermostat control deviation.

5. The subbase mounting slots provide for minor out of level adjustments. Level the subbase using a spirit level, as shown in Fig. 3, and tighten subbase mounting screws.

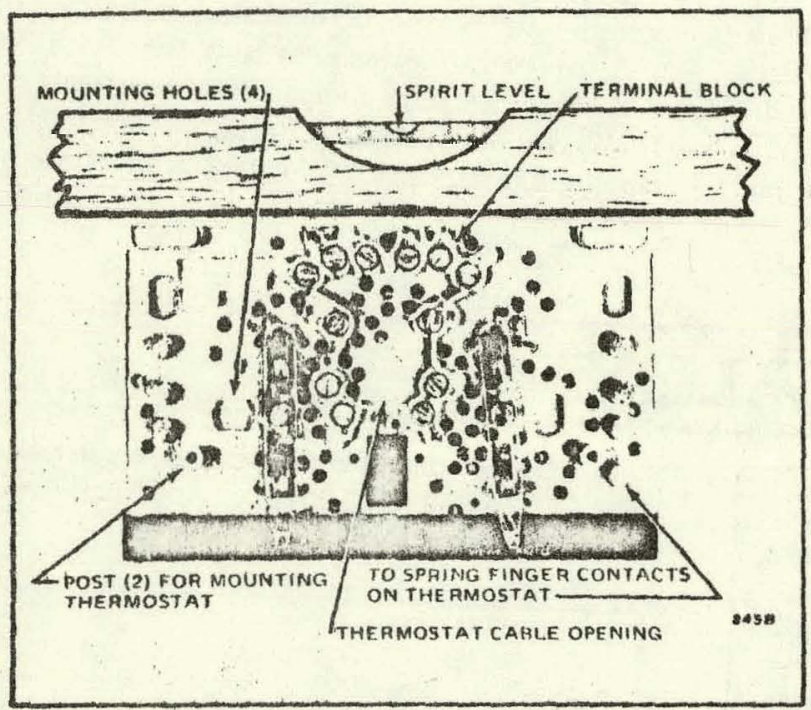

Fig. 3-LEVELING THE SUBBASE.

\section{WIRING}

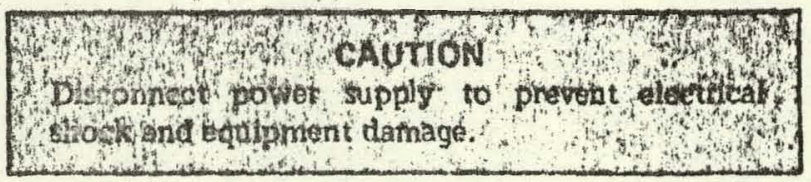

All wiring must comply with local electrical codes and ordinances.

A letter code is near each terminal for easy identification. Typical terminal designation and wiring connec. tions are listed in Table 3.

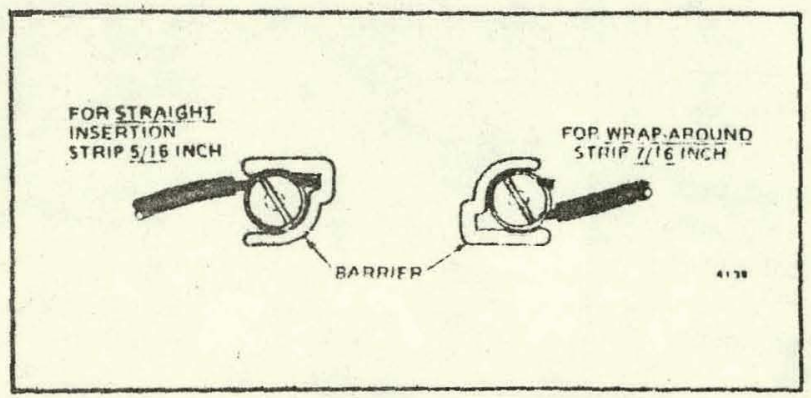

FIG. 4-BARRIER CONFIGURATION.
TABLE 3-TERMINAL DESIGNATIONS

\begin{tabular}{c|l}
\hline TERMINAL & \multicolumn{1}{|c}{ TYPICAL CONNECrION } \\
\hline$B$ & $\begin{array}{l}\text { Heating damper motor; changeover valve } \\
\text { (if used). }\end{array}$ \\
\hline$E$ & Emergency heat relay. \\
\hline$G$ & Fan relay coil \\
\hline$O$ & $\begin{array}{l}\text { Cooling damper motor; changeover valve } \\
\text { (if used). }\end{array}$ \\
\hline$R$ & $\begin{array}{l}\text { Power connection to trans former } \\
\text { (internally connected). }\end{array}$ \\
\hline$R_{C}$ & Power connection to cooling transformer. \\
\hline$R_{H}$ & Power connection to heating transformer. \\
\hline$W_{1}$ & Stage 1 heating control. \\
\hline$W_{2}$ & Stage 2 heating control. \\
\hline$Y_{1}$ & Stage 1 cooling control \\
\hline$Y_{2}$ & Stage 2 cooling control. \\
\hline$X_{1}$ & Clogged filter switch. \\
\hline
\end{tabular}

The shape of the terminal barrier permits insertion of straight or conventional wrap-around (Fig. 4) wiring connections. Either method is acceptable. When making connections, strip wire to the length specified in Fig. 4.

Follow the equipment manufacturer's wiring instructions, if available, when wiring the subbase. If not available, Figs. 6-29 show typical T872-Q672 system hookups.

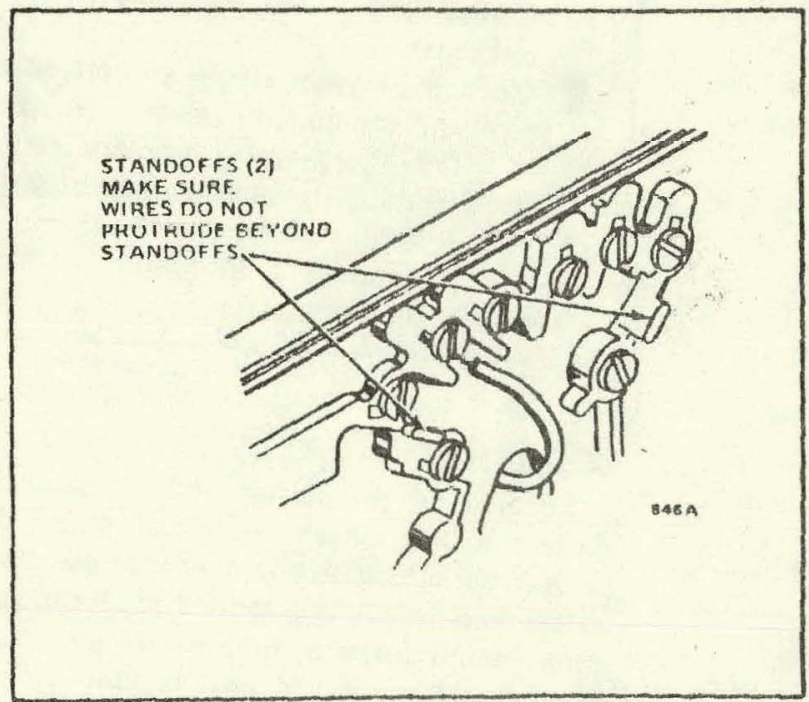

FIG. 5-INDIVIDUAL SCREW WIRING FOR 0672 SURRASE.

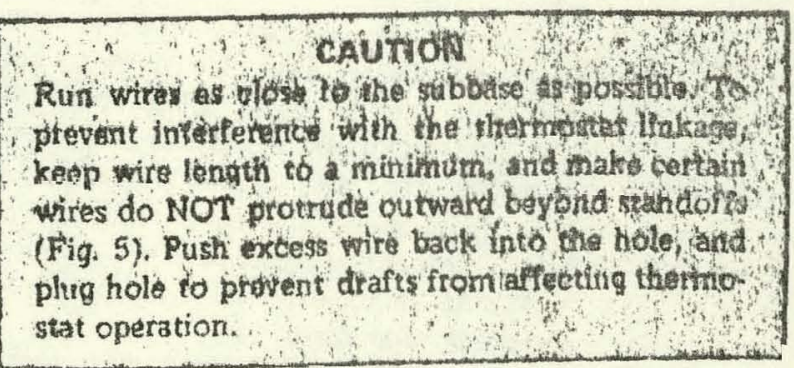


THE T675 AND T678 TEMPERATURE CONTROLLERS RECUL $\Lambda$ TE THE TEMPERATURE OF AIR OR LIQUIDS IN DUCTS, PIPES, AND TANKS. TYPICAL USES INCLUDE CONTROL OF DAMPERS AND VALVES IN HEATING, COOLING, OR HEATING-COOLING SYSTEMS.

口 T675A High Limit Controller makes a circuit on a rise in temperature.

口 T675B Low Limit Controller makes a circuit on a decrease in temperature.

- T678A Low Limit Controller makes two independent circuits in sequence on a decrease in temperature.

口 Fast response models with adjustable differential available.

c] Ambient temperature compensated.

$\square$ Setting knob on front.

$\square$ Sensing element may be mounted up to 20 feet from controller case.

E.S.

REV. 11.75
FORM $60-2200-1$

RESIDENTIAL DIV.

\section{TEMPERATURE CONTROLLERS}
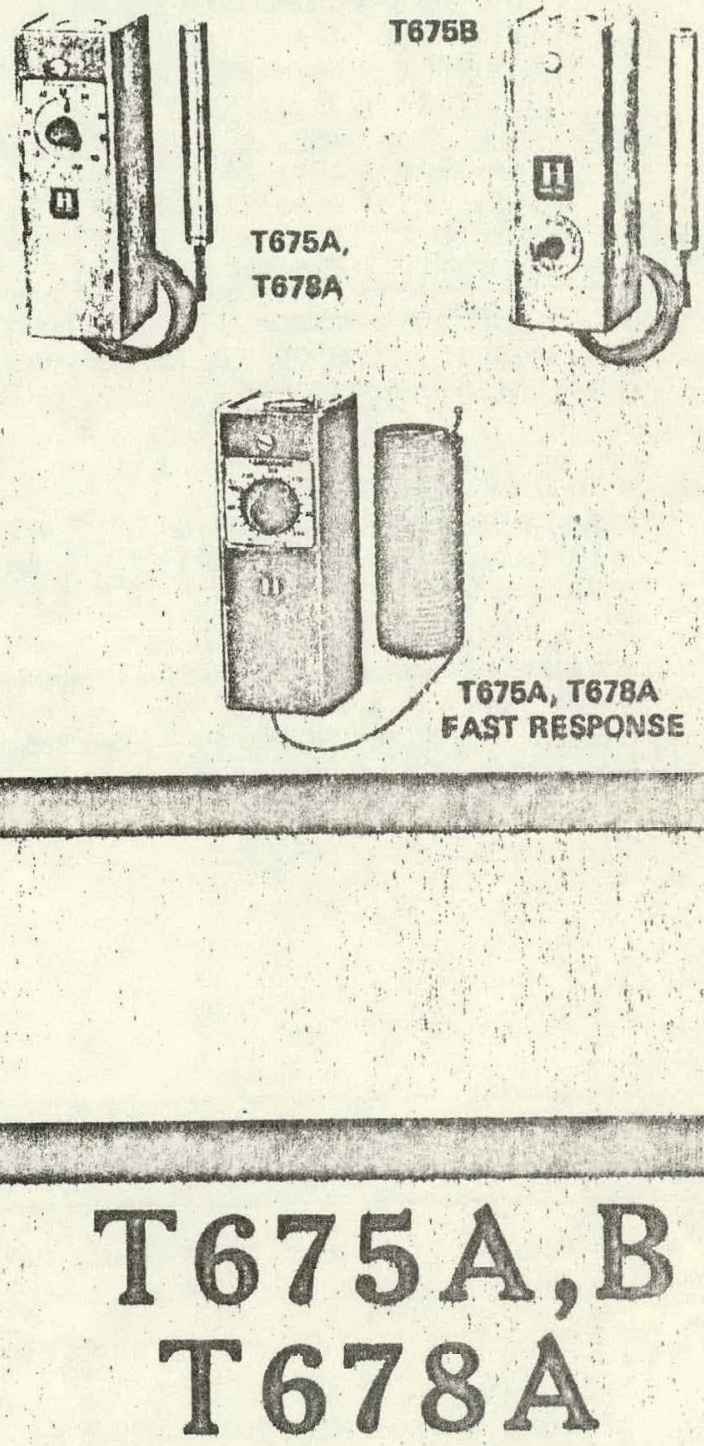

Homeywell. 


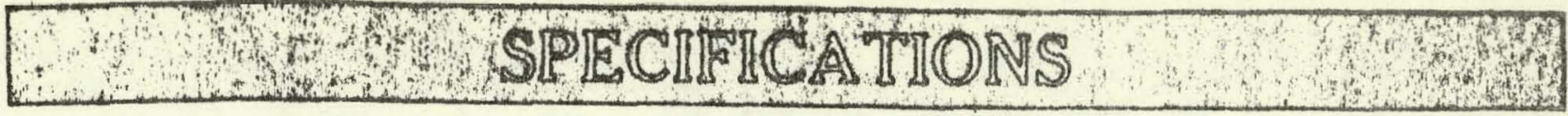

MODELS (also refer to Table 1):

T675A Temperature Controller - spdt switching to make or break a circuit on a temperature change; fast response models operate approximately seven times faster than standard models.

T675B Low Limit Temperature Controller breaks a circuit on a temperature fall; must be manvally reset.

T678A Temperature Controller-two spdt switches operate two independent circuits in sequence; fast response models operate approximately seven times faster than standard models.

TABLE I

\begin{tabular}{c|c|c|c|c}
\hline \hline $\begin{array}{l}\text { MODEL } \\
\text { NO. }\end{array}$ & RANGE & MAX. & SWITCHING \\
\hline & 0 to $100 \mathrm{Fa} / 15$ to $35 \mathrm{C}$ & $125 \mathrm{~F}$ & \\
T675A & 55 to $175 \mathrm{Fa} / 15$ to $75 \mathrm{C}$ & $200 \mathrm{~F}$ & spdt \\
& 80 to $180 \mathrm{~F} / 30$ to $80 \mathrm{C}$ & $200 \mathrm{~F}$ & \\
& 160 to $280 \mathrm{~F} / 75$ to $125 \mathrm{C}$ & $2 \mathrm{CBO}$ & \\
\hline T675Bb & 30 to $50 \mathrm{~F}$ & $125 \mathrm{~F}$ & spst \\
\hline & 0 to $100 \mathrm{Fa} /-15$ to $35 \mathrm{C}$ & $125 \mathrm{~F}$ & \\
T678A & 55 to $175 \mathrm{Fa} / 15$ to $75 \mathrm{C}$ & $200 \mathrm{~F}$ & \\
& 80 to $180 \mathrm{~F} / 30$ to $80 \mathrm{C}$ & $200 \mathrm{~F}$ & two spdt \\
& 160 to $260 \mathrm{~F} / 75$ to $125 \mathrm{C}$ & $280 \mathrm{~F}$ & \\
\hline
\end{tabular}

a Available with fast response sensing element.

b $675 \mathrm{~B}$ scale is marked $30,40,50$; get point is factory set and locked at $37 \mathrm{~F}$.

\section{SWITCH DIFFERENTIALS:}

T675A-fired differential models-1 F (.6 C); adjustable models -3 to $10 \mathrm{~F}(1.7$ to $5.6 \mathrm{C}$ ); fast response models -3.6 to $12 F(2$ to $6 . \theta \mathrm{C}$ ). T675B-11xed $10 \mathrm{~F}(5.6 \mathrm{C})$.

T678A-fixed $3 \mathrm{~F}$ per switch with adjustable interstage 3 to $10 \mathrm{~F}(1.7$ to $5.6 \mathrm{C})$; models with 55 to $175 \mathrm{~F}$ scale-fixed $3.6 \mathrm{~F}(2 \mathrm{C})$ per switch with adjustable interstage 3.6 to $12 \mathrm{~F}$ (2. to $6,6 \mathrm{C})$.
ELECTRICAL RATINGS:

T675 A adjustable models and T678A:

\begin{tabular}{l|c|r}
\hline & $120 \mathrm{v} \mathrm{ac}$ & $240 \mathrm{v} \mathrm{ac}$ \\
\hline Full Load & 8.0 & 5.1 \\
\hline Liocked Rotor & 48.0 & 30.6 \\
\hline
\end{tabular}

T675A nonadjustable models, $125 \mathrm{va}$ at $120 / 208 /$ $240 \mathrm{v}$ ac。

T675B 125 va at $240 \mathrm{v}$ ac pilot duty.

\section{MAXIMUM AMBIENT OPERATING TEMPERATURE:} $125 \mathrm{~F}$.

NOTE: The maximum recommended ambient for the T675B, when used for freeze-up protection, is $100 \mathrm{~F}$. An ambient of $125 \mathrm{~F}$ lowers the ewitch break point about $1.5 \mathrm{~F}$.

BULB SIZE: $1 / 2 \times 4-3 / 16$ inches for 0 to $100 \mathrm{~F}$ models; $1 / 2 \times 3-9 / 16$ inches for other scale ranges.

MAXIMUM BULB PRESSURE: 50 psig direct immersion.

\section{CAPILLARY LENGTH AND IVIATERIAL:}

T675A, T678A standard response models -5 or 20 foot copper, or 20 foot Monel or stainless steel.

T675A, T678A fast response models -5 foot copper with the sensing portion of element $1-1 / 2$ inch dia. $x$ 5 inches long (coiled 1/8 inch tubing). The coil may be stretched to approximately 10 inches.

T675B-10 foot copper.

CAPILLARY HOLDER: IOneywell part 131524A inclnded with all fast responso models.

(continued an pege 3)
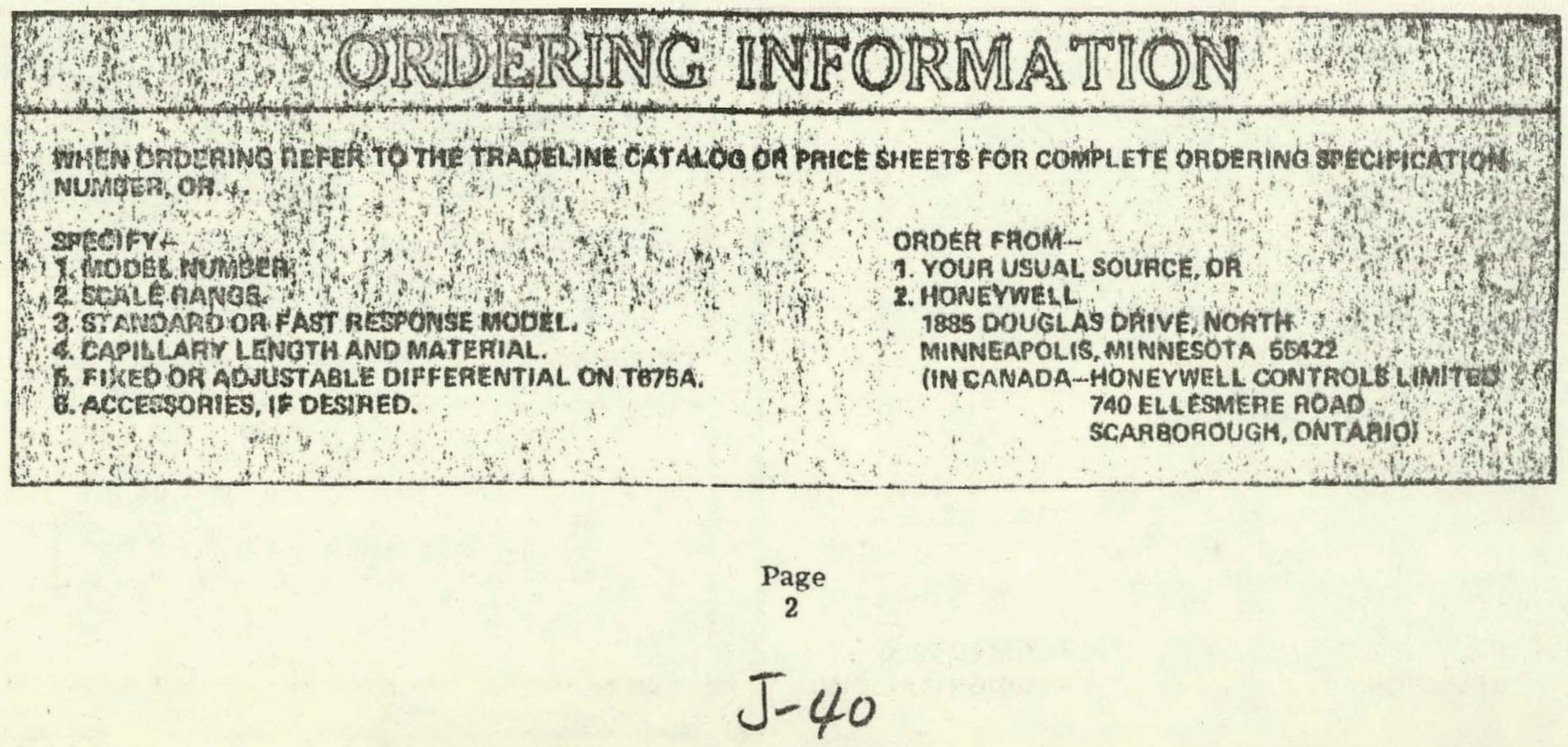
DIMENSIONS: See Fig. 1.

LISTING BODIES: Listed by Underwriters' Laboratories, Inc.

\section{ACCESSORIES:}

1. Separable immersion wells; short necked, 1/2 inch NPT, copper - order 112622AA. For additional information on immersion wells see Honeywell Tradeline Catalog.

2. Pressure fitting rated at 50 psi water or $15 \mathrm{psi}$ air-order $7617 \mathrm{ABY}$. For additional information on pressure fittings see Honeywell Tradeline Catalog.

3. Duct bulb holder 311266 ; also refer to Honeywell Tradeline Catalog.

4. T-strap 105900 for strapping the bulb to a pipe.

5. Bag assembly $7617 \mathrm{ABZ}$ with bracket for mounting the controller to fan coil units.

6. Calibration wrench 801534 .

7. Bag assembly 7640HY with standoff bracket for mounting the controller to an insulated duct.

8. Q615A weatherproof enclosure.

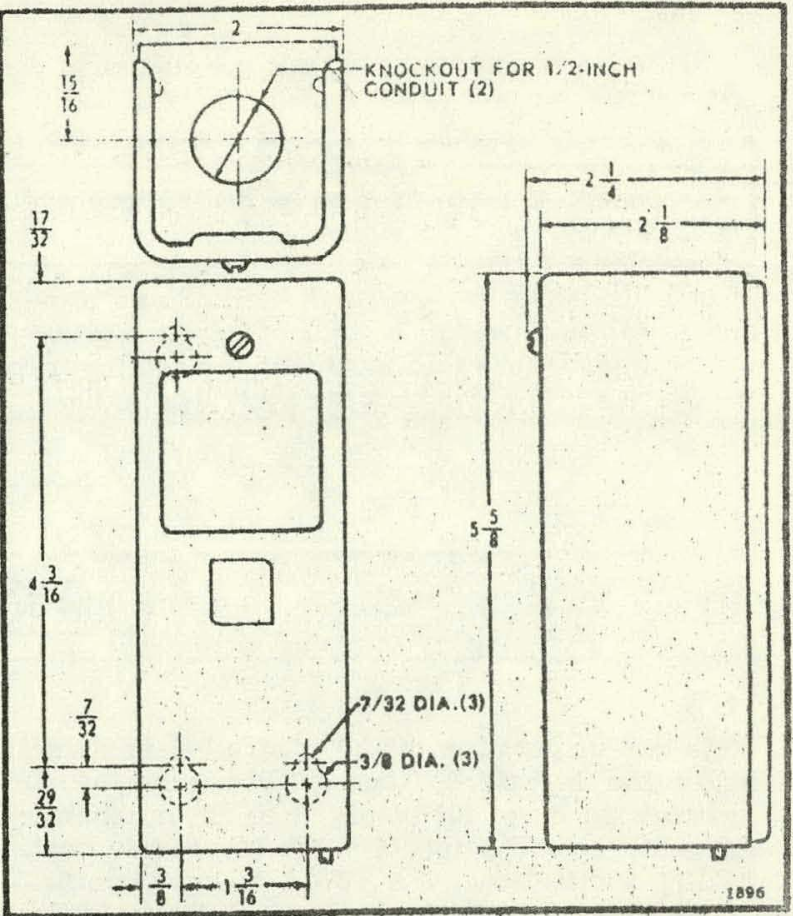

FIG. 1-DIMENSIONS IIN INCHES) OF TG75 AND T678 CON. TROLLEAS.
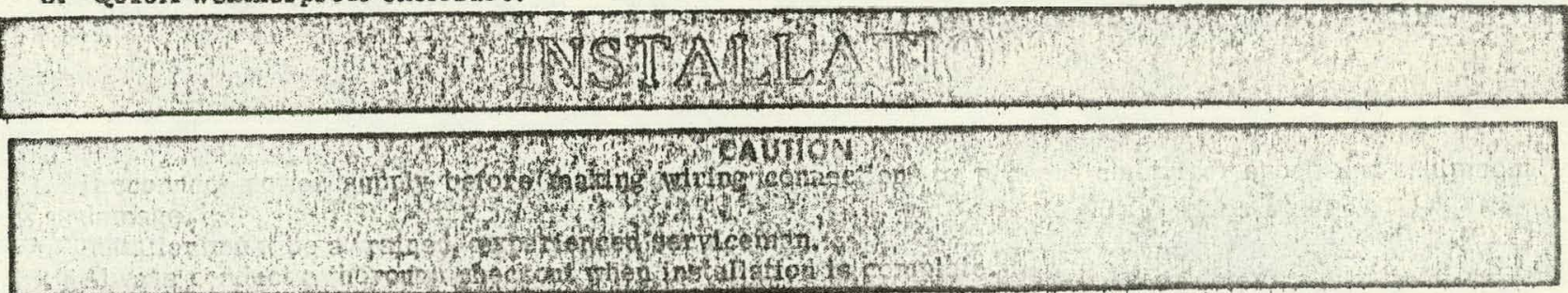

\section{LOCATION AND MOUNTINC}

The controllex may be installed in any convenient position. Be sure to consider the length of the capIllary before mounting controller.

Install the sensing element where it is exposed to the average temperature of the controlled medium. T675A fast reaponse models must use the capillary holder furnished with the device. The sensing bulb of standard models should be held in place with a bulb holder, immersion well, or pressure fittings. (See Figs. 2-4.) Sharp bends or kinks in the capillary tubing affect the efflciency of the controller and must be avoided. Excess capillary should be carefully coiled and left directly beneath the controller.

NOTE: When pressure fittings are used in areas of vibration auch as pipe lines, the bulb must be adequately supported.

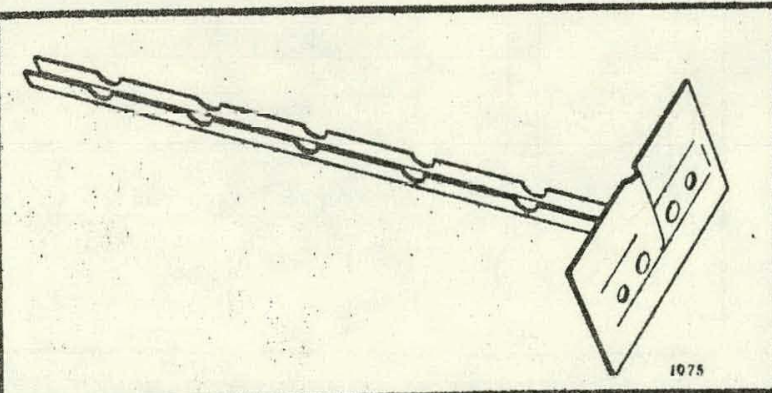

FIG. 2-BULB HOLDER FOR MOUNTING SENSING ELEMENT.

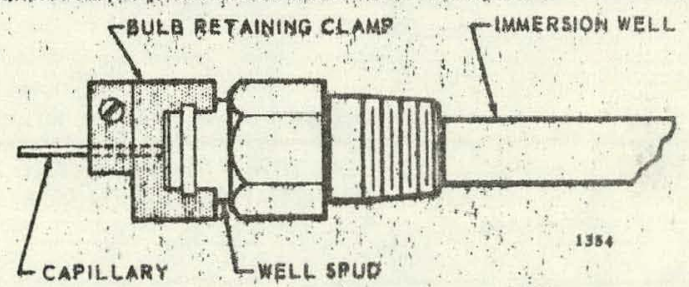

FIG. 3-IMMERSION WELL ASSEMBLY FOM MOUNTING SENSING BULB.

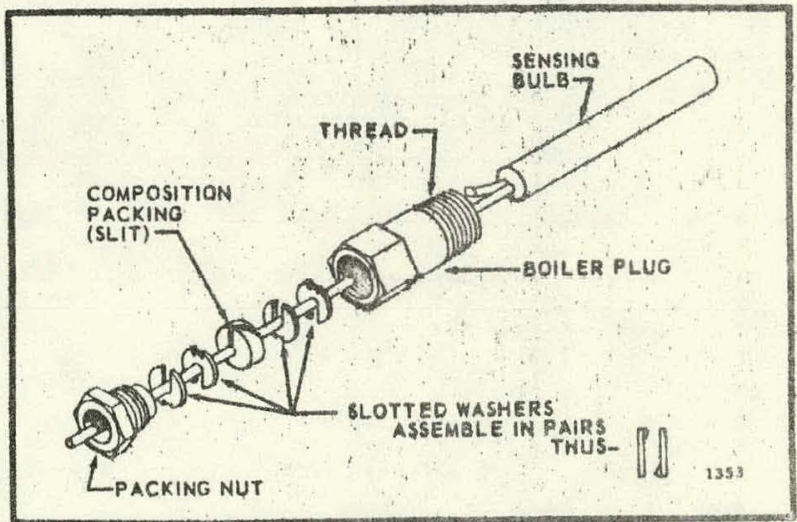

FIG. 4-COMPRESSION FITTINO FOR PRESSURE TICHT MOUNTING OF SENSING ELEMENT. 


\section{WIRING}

All wiring must comply with local electrical codes and ordinances.

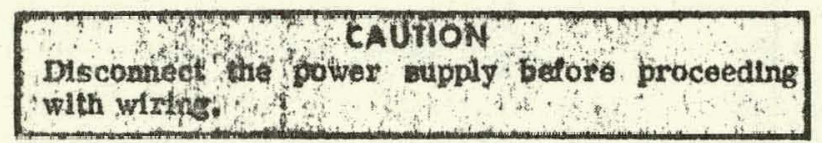

Two knockouts for $1 / 2$ inch conduit are provided, one at top and one at bottom of case. Follow the wiring instructions furnished with the heating or cooling system. Fig. 5 shows the switching action.

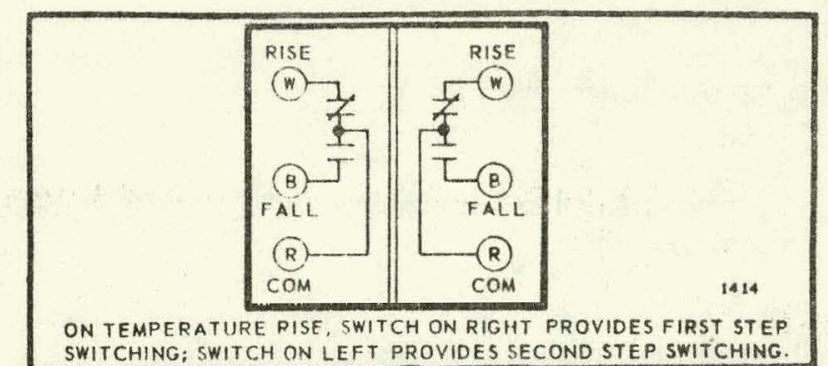

FIG. 5-T678A SWITCHING ACTION. T675A IS SIMILAR BUT HAS ONLY ONE SPDT SWITCH. T675B HAS ONE SPST SWITCH.

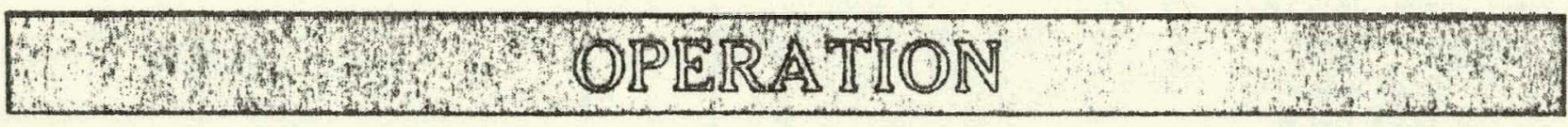

\section{T675A}

As the temperature of the controlled medium falls veluw the eet polit, less ulfferential, the T675A switches to make terminals $R$ to $B$ and energize a normally closed solenoid valve to provide heat. In cooling applications, the T675A makes terminal $R$ to $W$ as the temperature rises above the set point and energizes cooling equipment. Fig. 7 shows the operation of the T675A.

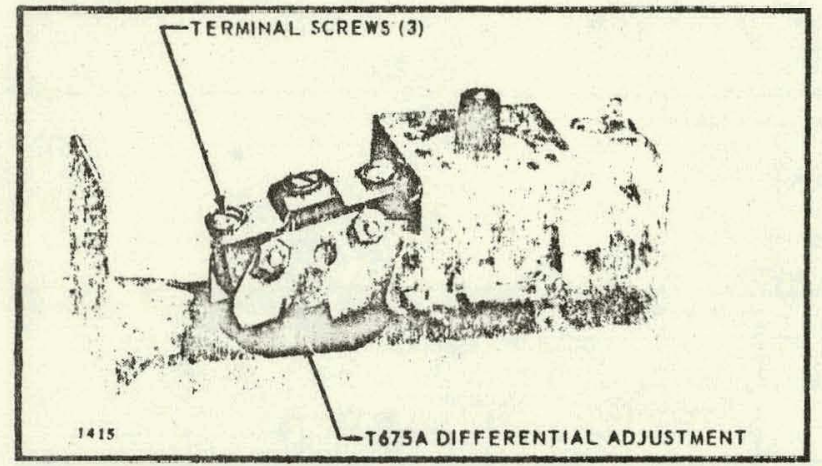

FIG. 6-INTERNAL: VIEW OF T675A SHOWING THE SWITCH DIFFERENTIAL ADJUSTMENT WHEEL (APPLICABLE MODELS).

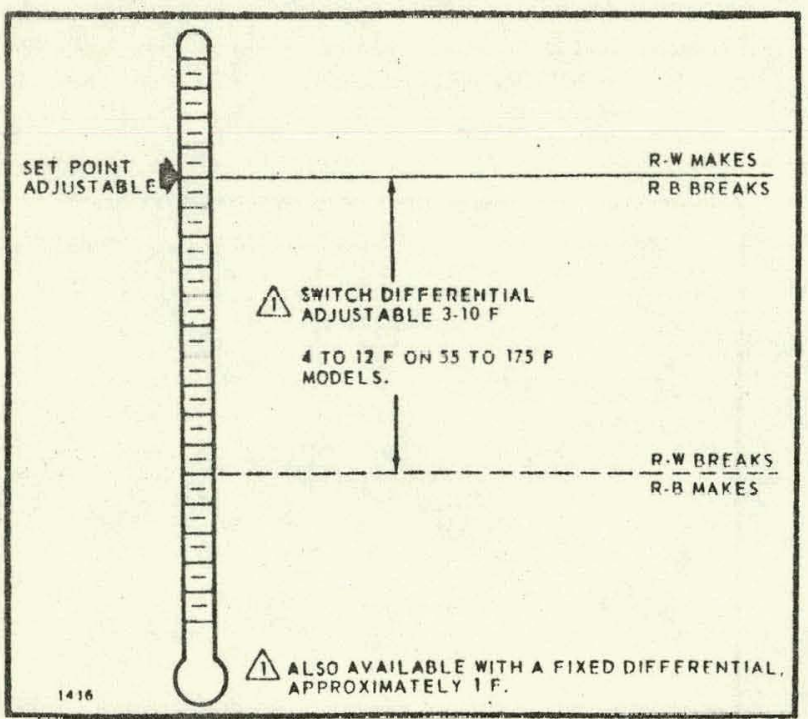

FIG. 7-DIFFERENTIAL ADJUSTMENT RANGE OF T675A.

\section{FREEZE-UP PROIECIION}

When using the $\mathrm{T} 675 \mathrm{~A}$ (auto-recycling) for freezeup protection, the recommended set point is $38 \mathrm{~F}$ plus the switch differential.

example: SET POINT $38 \mathrm{~F}$, plus $1 \mathrm{~F}$ (íxed differential model) equals an actual set polnt of $39 \mathrm{~F}$.

example: SET POINT $38 \mathrm{~F}$, plus $3 \mathrm{~F}$ (adjustable differential model) equals an actual set point of $41 \mathrm{~F}$.

This ensures adequate safety factor for freeze-up protection.

NOTE: The T675B is a manual reset device and is specifically designed for freeze-up protection.

\section{T675B}

Used as a low limit controller, the $\mathrm{T} 675 \mathrm{~B}$ interrupts the operation of equipment if the temperature of the controlled medium falls below a predetermined limit. The device is reset manually after a rise in temperature of approximately $10 \mathrm{~F}$. The operation of T675B is shown graphically in Fig. 8 .

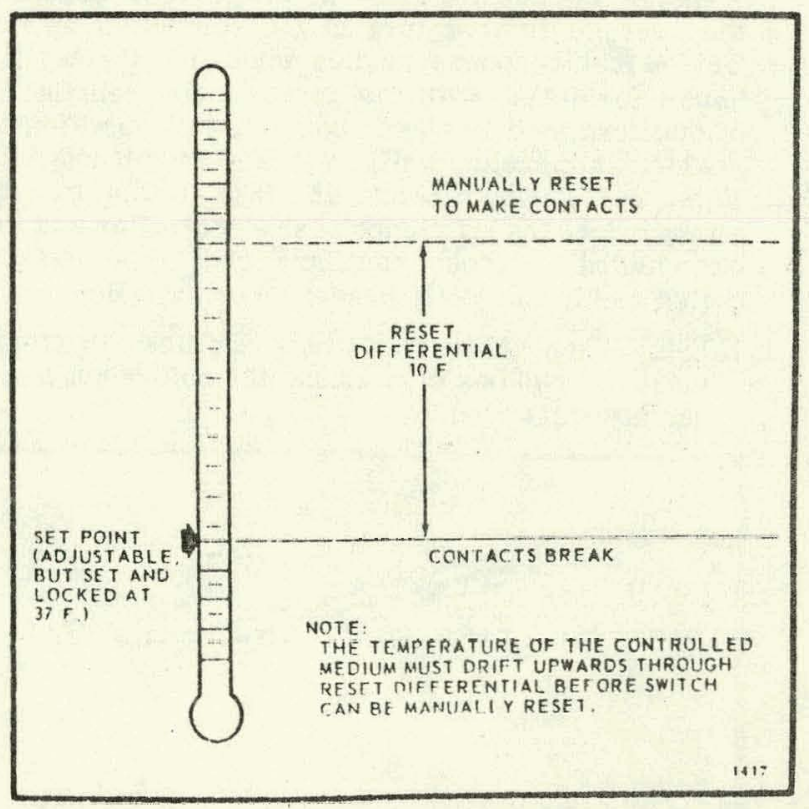

FIG. 8-DIFFERENTIAL ADJUSTMENT RANGE OF T675B. 
T678A

When the temperature at the sensing bulb rises above the setting of the controller, the switch on the right completes a circuil between the R-W terminals of that switch. Should the temperature contime to rise through the preselected interstage differential of the controller, the switch on the left will complete its R-W circuit.

Conversely, on a temperature fall the switch on the left provides first step switching. If the temperature continues to fall, the switch on the right completes its R-B circuit to provide sequencing of equipment.

Each T678 has a between-6witch differential adjustment. Make this adjustment by inserting a narrow screwdriver into the rectangular hole in the chassis (Bee Fig. 9) and pushing the star wheel. At its maximum position; intergtage differential is $10 \mathrm{~F}$. At minimum position differential is $3 \mathrm{~F}$. Adjust until catisfactory operation is achieved.

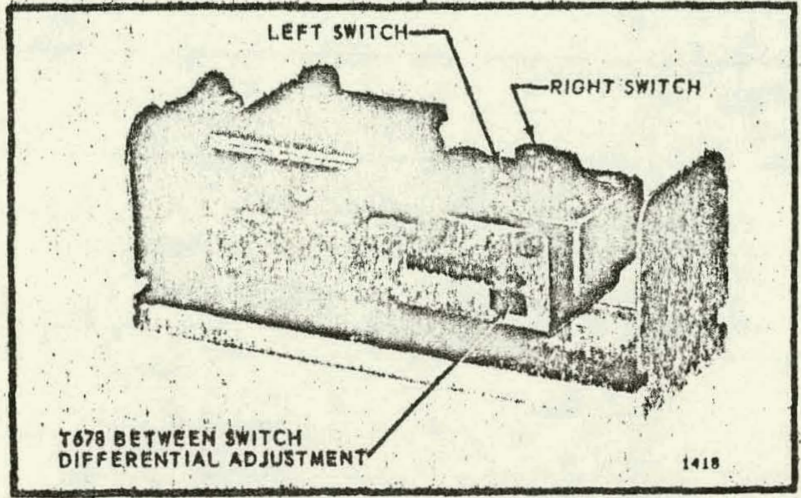

FIQ. S-INTERNAL VIEW OF T679A SHOWING THE BETWEEN SWITCH DIFFERENTIAL. ADJUSTMENT.
The T678A Temperature Controller may be adjusted to give an interstage differential of three to ten degrees above the set point. The set point adjustment dial determines the temperature at which the right switch operates. The operation of the left switch is adjustable from three to ten degrees above that point of operation. An illustration depicting the operation of the T678A is shown in Fig. 10.

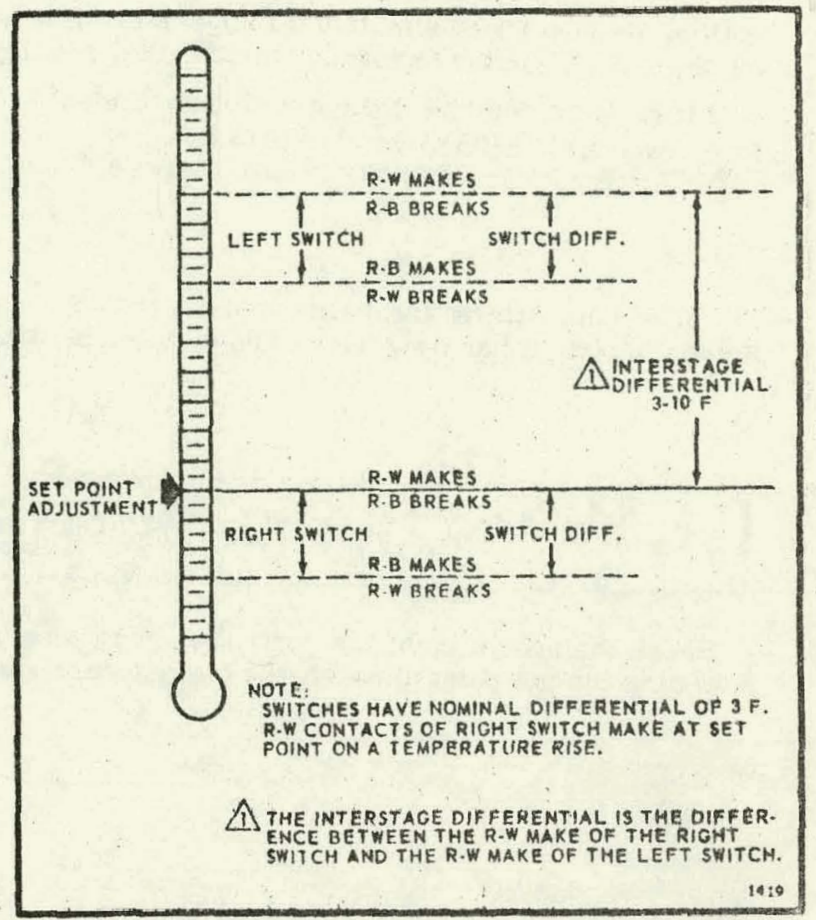

FIG. 10-DIFFERENTIAL ADJUSTMENT RANGE OF T678A.

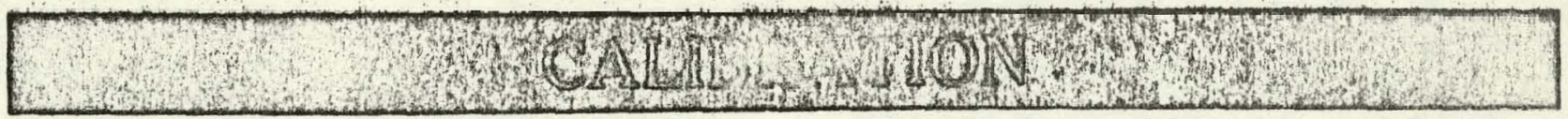

All controllers are carefully tested and calibrated at the factory under controlled conditions. If the controller is not operating at a temperature corresponding to the scale setting and differential setting, check to see that the bulb senses the average temperature of the medium controlled. If the temperature of the controlled medium is changing rapidly the differential will appear wider than its setting.

For calibration, an accurate temperature reading of the controlled medium must be taken. Place an accurate thermometer near the bulb of the controller, or refer to a thermometer that has been Installed as part of the system. If the bulb of the controller is installed in an inaccessible area, or if the controlled modium is unstable, it should be removed and placed in a controlled bath for accurate calibration.

\section{T675A}

These controller are calibrated so that the dial setting is the point at which the R-W switch contacts make on a temperature rise. Measure the tempera- ture at the bulb. Rotate the dial counterclockwise 7 from the top of the scale, simulating a temper ature rise, until the $\mathrm{R}-\mathrm{W}$ switch contacts mako. Note the dial reading. If it differs from the set point, calibrate lie dlal as follows:

1. Determine the number of degrees difference between the set point and the point at which the contacts make.

2. Remove the dial knob and slip the fingers of the calibration wrench into the slots of the dial. Rotate the dial until the fingers of the wrench drop into the slots of the calibration nut under the dial. Note the dial indication at this point. Turn the dial and the calibration nut up or down scale the number of degrees that the set point differs from the point at which the contacts make (determined in step 1). For eramplo, move dial from 45 to 65 degrees for a 20 degreo change in calibration.

3. Check the callbration adjustment by moving the dial up and down the scale while watching the contacts make and break. If dial is still out of calibration, repeat calibration procedure. 


\section{8}

These controllers are calibrated so that the dial setting is the point at which the switch contacts break on a temperature fall. Measure the temperature at the bulb. Rotate the dial clockwise 7 from the bottom of the scale to simulate a temperature fall until the switch contacts break. Note the dial reading.

If it differs from the get point, follow the calibration procedure outlined for the T675A.

\section{T678A}

These controllers are calibrated so that the nonadjustable (right hand) switch makes on a temperature rise and the adjustable (left hand) switch makes 3 to $10 \mathrm{~F}$ higher. The point at which the nonadjustable switch makes represents the dial setting. Rotate the dial reading. Continue rotating the dial until the left hand switch makes. The difference between the two reading $s$ is the interstage differential. The left hand switch must make at a lower reading than the right hand switch. Adjust the differential if necessary, Changing the differential may change tho calibration.

Measure the temperature at the bulb. Rotate the dial counterclockwige from the top of the scale to simulate a temperature rise until the contacts of the left hand switch make, Note the reading.

If it differs from the set point, follow the procedure outlined for the T675A.

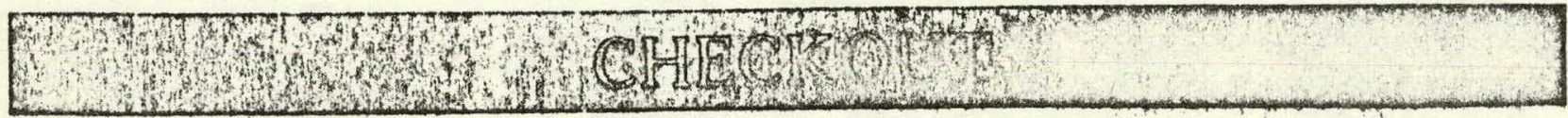

Check the nperation of the controller by raising and lowering the set point through the temperature range of the air or liquid baing controlled. Make pure that controlled equipment operates as lutauded. 
Moneywell

AQUASTAT CONTROLLERS ARE IMMERSION TYPE DEVICES FOR LIMITING OR REGULATING THE TEMPERATURE OF LIQUIDS IN BOILERS, STORAGE TANKS, AND OTHER APPLICATIONS WHERE TEMPERATURE CONTROL OF LIQUIDS IS REQUIRED. AS THE TEMPERATURE OF THE CONTROLLED MEDIUMRISESTOTHE SET POINT, EXPANSION OF THE FLUID IN THE SENSING ELEMENT OPERATES THE INTERNAL SWITCH OR SWITCHES.

$\square$ The $L 4006,7$, and 8 provide spst switching for high or low limit control of a burner.

$\square$ The L4006G model has two spst switches that make and break in sequence to provide boiler sequencing.

$\square$ The L6006 and 8 provide spdt switching for low limit and circulator control.

$\square$ Models which break contact on a temperature rise to the set point are calibrated for high limit use. They are also suitable for low limit control if a separate high limit control is used.

$\square$ Ambient compensated models are available to prevent control-point shift caused by temperature fluctuation at the case.

Visible control point scale and external arjustment screw permit easy setting.

Models are available for either horizontal or vertical insertion of the sensing element. The sensing element may be directly immersed or placed in an immersion well.

Romote bulb models are available if the controller must be mounted at a location away from the sensing element.

Remote bulb models may also be used to sense air temperature in ducts and in outside air sensing applications.

Totally enclosed Micro Switch snap-acting switches are used in all models.

S.K.

7.75

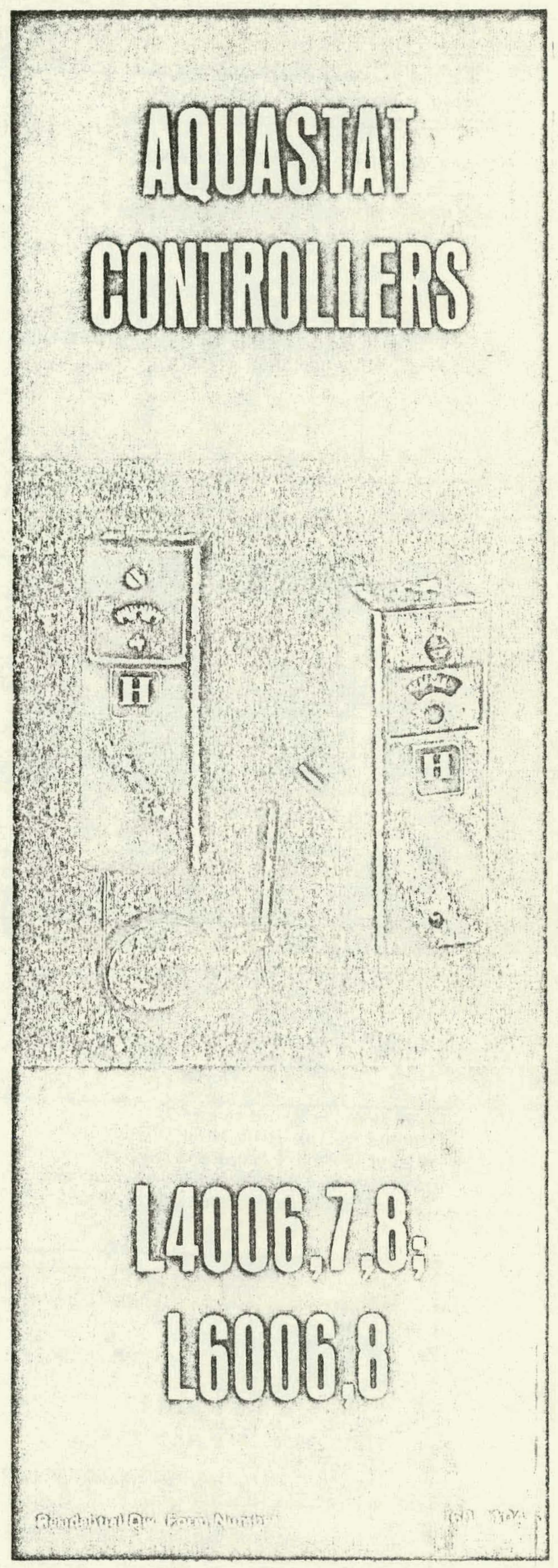




\begin{tabular}{|c|c|c|c|c|c|c|}
\hline MODEL & APPLICATION & RANGE (F) & $\begin{array}{c}\text { MIDSCALE } \\
\text { DIFFERENTIAL } \\
(\mathrm{F})\end{array}$ & INSERTION ${ }^{\mathrm{a}}$ & $\begin{array}{l}\text { SWITCHING } \\
\text { ON TEMP. } \\
\text { RISE }\end{array}$ & AVAILABLE OPTIONS \\
\hline L4006A & $\begin{array}{l}\text { high or low } \\
\text { limit }\end{array}$ & $\begin{array}{r}40 \text { to } 180 \\
100 \text { to } 240\end{array}$ & $\begin{array}{l}2 \text { or } 5 \text { fixed or } \\
5 \text { to } 30 \text { adj. }\end{array}$ & horizontal & breaks & $\begin{array}{l}\text { Tradeline models which in- } \\
\text { clude well and tube of heat } \\
\text { conductive compound. Plas- } \\
\text { tic shield for covering well } \\
\text { in water heater applications. } \\
3 / 4 \text { in. NPT brass spud. } \\
\text { Centigrade scale markings. } \\
\text { Factory set stops at } 160 \mathrm{~F} \text {, } \\
185 \mathrm{~F}, 190 \mathrm{~F}, 200 \mathrm{~F}, \text { or } \\
220 \mathrm{~F} \text {. Dial marker WARM, } \\
\text { NORMAL, HOT. Insulation } \\
\text { depths of } 1-1 / 2,3 \text {, or } 5 \\
\text { inches, }\end{array}$ \\
\hline LA006B & circulator & $\begin{array}{c}40 \text { to } 180 \\
\text { or } \\
100 \text { to } 240\end{array}$ & $\begin{array}{l}5 \text { fixed or } \\
5 \text { to } 30 \text { adj. }\end{array}$ & horizontal & makes & $\begin{array}{l}3 \text { inch insulation depth, } 3 / 4 \\
\text { inch NPT brass spud. }\end{array}$ \\
\hline L4006C & $\begin{array}{l}\text { high or low } \\
\text { limolt }\end{array}$ & 100 to 240 & 2 or 5 fixed & $\begin{array}{l}\text { horizontal } \\
\text { direct }\end{array}$ & breaks & $\begin{array}{l}10 \text { in. element. Factory } \\
\text { set stop at } 205 \mathrm{~F} \text {. }\end{array}$ \\
\hline L4006Eb & high limit & 110 to 250 & $\begin{array}{l}\text { manual } \\
\text { resset }\end{array}$ & $\begin{array}{l}\text { horizontal } \\
\text { or vertical }\end{array}$ & breaks & $\begin{array}{l}3 / 4 \text { in. NPT brass apud. } 3 \\
\text { in, insulation depth. }\end{array}$ \\
\hline $\mathrm{L} 4006 \mathrm{G}$ & sequencing & 100 to 240 & $\begin{array}{l}5 \text { fixed } \\
\text { interstage } \\
3-10 \mathrm{~F} \text { adj. } \\
\end{array}$ & $\begin{array}{l}\text { horizontal } \\
\text { or vertical }\end{array}$ & \begin{tabular}{|l|} 
breaks \\
two \\
switches \\
\end{tabular} & \\
\hline LA007A & $\begin{array}{l}\text { high ox low } \\
\text { Jimit }\end{array}$ & 100 to 240 & $\begin{array}{l}2 \text { or } 5 \text { fixed, } \\
5 \text { to } 30 \text { adile }\end{array}$ & vertical & breaks & Centigrade scale maxkingf. \\
\hline $\mathrm{L} 4007 \mathrm{~B}$ & circulator & 100 to 240 & $\begin{array}{l}5 \text { fixed or } \\
5 \text { to } 30 \text { adje. }\end{array}$ & vertical & makes & $\longrightarrow+1$ \\
\hline $\mathrm{L}, 4008 \mathrm{~A}^{\mathrm{a}}$ & $\begin{array}{l}\text { high or low } \\
\text { limit }\end{array}$ & $\begin{array}{l}40 \text { to } 180 \\
\text { or } \\
100 \text { to } 240\end{array}$ & $\begin{array}{l}2 \text { or } \\
5 \text { fixed, } \\
5 \text { to } 30 \text { adj. }\end{array}$ & $\begin{array}{l}\text { remate } \\
\text { bulb }\end{array}$ & breaks & $\begin{array}{l}5 \mathrm{ft} .6 \text { in., } 8 \mathrm{ft} .8 \text { in. or } 10 \mathrm{ft} \text {. } \\
\text { remnte rapillary. Factory } \\
\text { set scale stop at } 120 \text { or } \\
200 \mathrm{~F} \text {. External adjusting } \\
\text { knob. Centigrade scale } \\
\text { marking }\end{array}$ \\
\hline $\mathrm{L}^{4} 4008 \mathrm{~B}^{2}$ & eirculator & 100 to 240 & $\begin{array}{l}5 \text { fixed or } \\
5 \text { to } 30 \text { adj. }\end{array}$ & $\begin{array}{l}\text { remote } \\
\text { bulb }\end{array}$ & makes & $8 \mathrm{ft} .6 \mathrm{in}$ capillaty. \\
\hline$L 4008 C^{a}$ & $\begin{array}{l}\text { ambient } \\
\text { compensated } \\
\text { high limit }\end{array}$ & $\begin{array}{c}0 \text { to } 70 \\
\text { or } \\
40 \text { to } 180\end{array}$ & 2 or 5 fixed & $\begin{array}{l}\text { remote } \\
\text { bulb }\end{array}$ & breaks & $\begin{array}{l}7 \mathrm{ft}, 6 \text { in., } 20 \text { ftecaplliary ar } \\
\text { fast response element. } \\
\text { External adj. knob. 150 va } \\
\text { rating at } 120,240 \mathrm{v} \text { ac. } \\
\text { Kigh limit ottmped on case } \\
\text { scale lock. }\end{array}$ \\
\hline
\end{tabular}

t\$008 modals continued on page 3

a Copper well or fitting is supplied with all models except remote bulb type. When ordering, opecify boller tapping size (1/2 or $3 / 4$ inch) and insulation depth.

bManual reset (trip-free) - Switchbreaks circuit and locks out when controlled medium reaches set point. Controlled temperature must drop 20 degrees below set point before contacts can be manually reset.

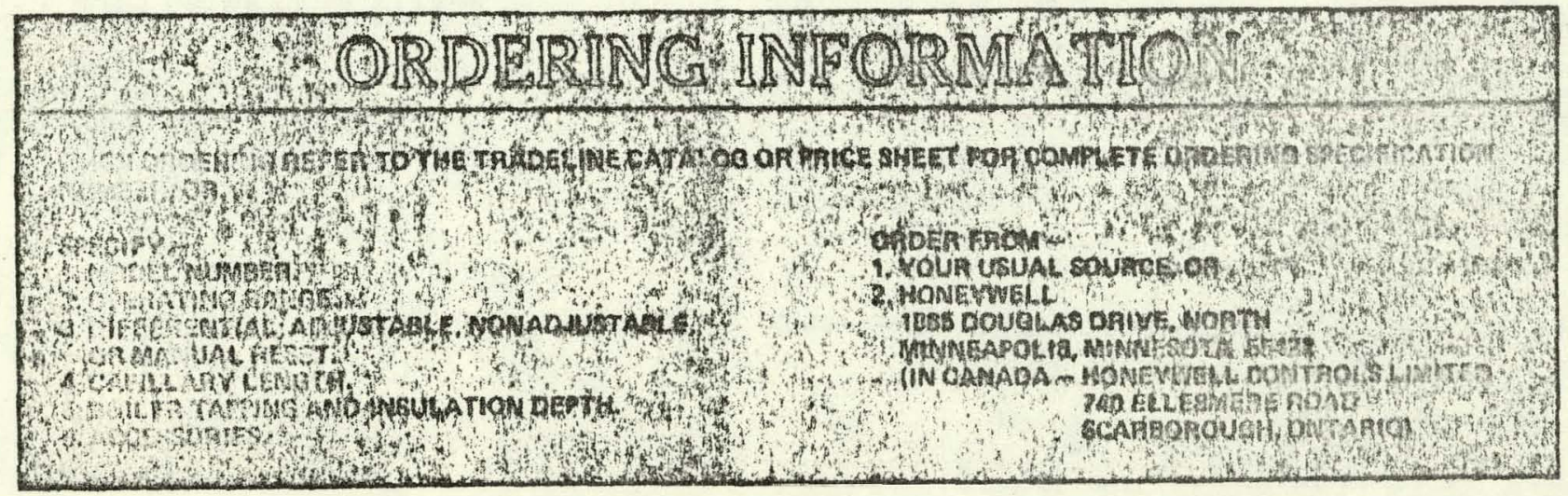




\begin{tabular}{|c|c|c|c|c|c|c|}
\hline MODEL & APPLICATION & RANGE (F) & $\begin{array}{c}\text { MIDSCALE } \\
\text { DIFFERENTLAL } \\
\text { (F) }\end{array}$ & INSERTIONa & $\begin{array}{l}\text { SWTTCHING } \\
\text { ON TEMP. } \\
\text { RISE }\end{array}$ & AVAILABLE OPTIONS \\
\hline $\begin{array}{c}\vdots \\
\text { LAOOBD }^{\mathbf{Q}} \\
\therefore\end{array}$ & $\begin{array}{l}\cdots \\
\text { ambient } \\
\text { compensated } \\
\text { c1rculator }\end{array}$ & $\begin{array}{l}0 \text { to } 70 \\
\text { or } \\
40 \text { to } 180\end{array}$ & 2 or $511 x e d$ & remote & 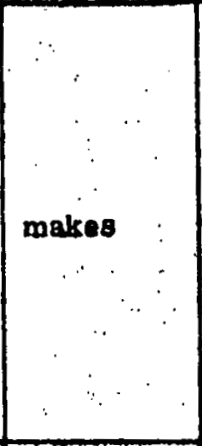 & 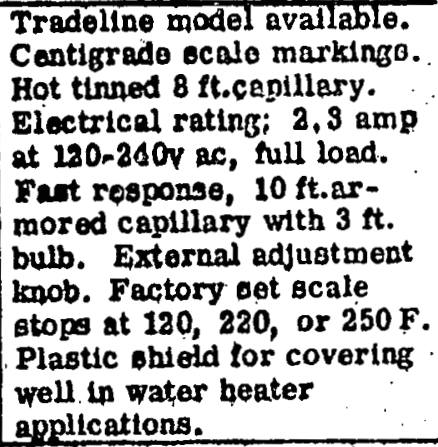 \\
\hline $\mathrm{L} 4008 \mathrm{E}^{\mathrm{ab}}$ & high limit & $\begin{array}{c}40 \text { to } 80 \\
\text { or } \\
110 \text { to } 290\end{array}$ & $\begin{array}{l}\text { manual } \\
\text { reset }\end{array}$ & $\begin{array}{l}\text { remote } \\
\text { bulb }\end{array}$ & breaks. & $\begin{array}{l}\text { Factory sot acalo stop at } \\
860 \text {. } 8 \mathrm{ft} .6 \mathrm{ln} \text {. capillary. }\end{array}$ \\
\hline$L 4008 J^{a}$ & high limit & 100 to 240 & 5 fixed & $\begin{array}{l}\text { remote } \\
\text { bulb }\end{array}$ & hroak & $\begin{array}{l}\text { All model less oase and } \\
\text { covar. } 18 \text { in. caplliary and } \\
1 / 2 \text { in. well assy. Factory } \\
\text { get acale gtop at } 220 \mathrm{~F}\end{array}$ \\
\hline LACOBKa & circulator & 40 to 180 & 5 fixed & $\begin{array}{l}\text { remote } \\
\text { bulb }\end{array}$ & males & Ail mpdole less cover. \\
\hline
\end{tabular}

\begin{tabular}{|c|c|c|c|c|c|}
\hline MODEL & APPLICATION & RANGE (F) & $\begin{array}{l}\text { MEDSCALE } \\
\text { DIFFERENTLAL (E) }\end{array}$ & INSERTION' & AVANLABLE ÓPTIONS \\
\hline $\mathbf{L 6 0 0 6 A ^ { a }}$ & $\begin{array}{l}\text { circulator } \\
\text { and low } \\
\text { limit or } \\
\text { high limit }\end{array}$ & $\begin{array}{l}100 \text { to } 240 \\
\text { or } \\
110 \text { to } 290\end{array}$ & $\begin{array}{l}5 \text { fixed or } \\
5 \text { to } 30 \text { add. }\end{array}$ & $\begin{array}{c}: \\
\text { hortgont } \\
\because\end{array}$ & 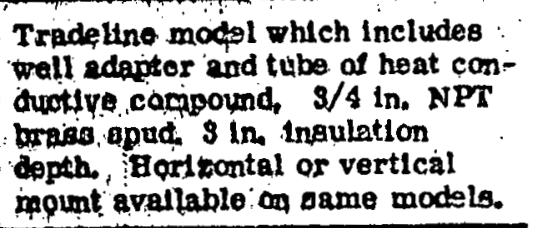 \\
\hline L6006B & $\begin{array}{l}\text { circulator } \\
\text { and low } \\
\text { limit or } \\
\text { high limit }\end{array}$ & 100 to 240 & $\begin{array}{l}5 \text { fixed or } \\
5 \text { to } 30 \text { adj }\end{array}$ & horizont & $\begin{array}{l}8 / 4 \text { in maps bulb compression } \\
\text { ftting, }\end{array}$ \\
\hline $\mathrm{L} 6008 \mathrm{~A}^{\mathrm{a}}$ & $\begin{array}{l}\text { circulator } \\
\text { and low limit } \\
\text { cooling }\end{array}$ & $\begin{array}{l}100 \text { to } 240 \\
-30 \text { to } 70\end{array}$ & $\begin{array}{l}5 \text { fixed or } \\
5 \text { or } 30 \text { adj. }\end{array}$ & $\begin{array}{l}\because \cdots \\
\text { semoto } \\
\text { bulb : }\end{array}$ & $\begin{array}{l}\text { Tradeline model with } 5 \text { ft.cap- } \\
\text { ullary. Range of -30.to } 70 \mathrm{~F} \text {. } \\
\text { Centigrade ecale markings. With- } \\
\text { out cover. }\end{array}$ \\
\hline$L 6008 C^{a}$ & $\begin{array}{l}\text { cual tuel } \\
\text { changeover }\end{array}$ & $\begin{array}{l}0 \text { to } 70 \\
40 \text { to } 180\end{array}$ & 2 or 5 fixed. & $\begin{array}{l}\text { remuke } \\
\text { bulb, } \\
\text { May be } \\
\text { duct mounted. }\end{array}$ & $\begin{array}{l}\text { Tradeline model. } 150 \text { va switch } \\
\text { rating. Centigrado soalo } \\
\text { markdngs. } 7 \text { ft. } 6 \text { ip. armored } \\
\text { captllary. External adjustment } \\
\text { knob. Lock type cover. } 20 \mathrm{ft} \text {. } \\
\text { glement. Averaging olement. }\end{array}$ \\
\hline$L 6008 E^{a}$ & $\begin{array}{l}\text { ambient } \\
\text { compensated }\end{array}$ & 40 to 180 & 5 fixed & $\begin{array}{l}\text { rempite } \\
\text { bulb? }\end{array}$ & $\begin{array}{l}\text { All modelo leBs enclosure. Front } \\
\text { mounted. }\end{array}$ \\
\hline
\end{tabular}

acopper well or fitting is supplied with all models except remote bulb type. When ordering, spocify boiler tappling Bize $(1 / 2$ or $3 / 4$ inch) and insulation depth.

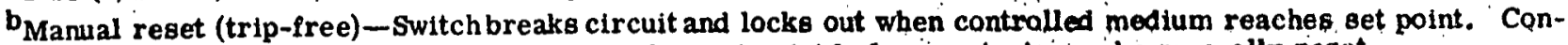
trolled tcmperature must drop 20 degrees below set point beloro contacts cap pe panually reget.

NOTE: The following specifications are standard. Variances, avallable as optlond, are noted in the preceding table.

ELECTRICAL RATING (AMPS):

Models with 2 F fixcd differential --

\begin{tabular}{l|c|c}
\hline & $120 \mathrm{v} \mathrm{ac}$ & $240 \mathrm{v} \mathrm{ac}$ \\
\hline FULL LOAD & 2.6 & 1.3 \\
\hline LOCKED ROTOR & 15.6 & 7.8 \\
\hline
\end{tabular}

Models with 5 F differential-

\begin{tabular}{|c|c|c|}
\hline & $120 \times 2 c$ & $240 \mathrm{y}, \mathrm{CL}$ \\
\hline FUL & 8 & 5.1 \\
\hline LOCKED & 48 & 30,6 \\
\hline INDUCTIVE CURRENT & \multicolumn{2}{|c|}{.25 at $1 / 4$ to $12 v \mathrm{dc}$} \\
\hline
\end{tabular}


JRESSURE RA'TING:

Capillary bulb (direct immersion)-200 psi. Imruersion wel!-255 psi.

SENSING BULB MATEKLAL: COpper.

SENSING BULB FULL: Liquid, Toluene or Silicone.

CAPILI,AKY LENGTH (including bulb): Renote bulb ' models-60 inches.

SENSING BULB DIMENSIONS (inches): 2-7/8 long, $3 / 8$ diameter.

INSERTION DEPTH: $9-3 / 8$ inches.

INSULATION: Brass. $1-1,2$ or 3 inches. Specify whell ordering.

PROVISION FOR WIRING: Screw terminals.

MOUNTING: Hörizontal and vertical models mount directly to an lmutision well installed in a boiler fitling. Hemote bulb models have 3 mounting holes rear of case for screw mounting to a vertical surfuce.

FINISH: Gray.

INSTALI,ATION DIMENSIONS: See Fig8, 1 and 2.

IMMERSION WELL DIMENSIONS: See FIg. 3.

BOILER FITTING AND BULB DIMENSIONS: See Fig. 4.

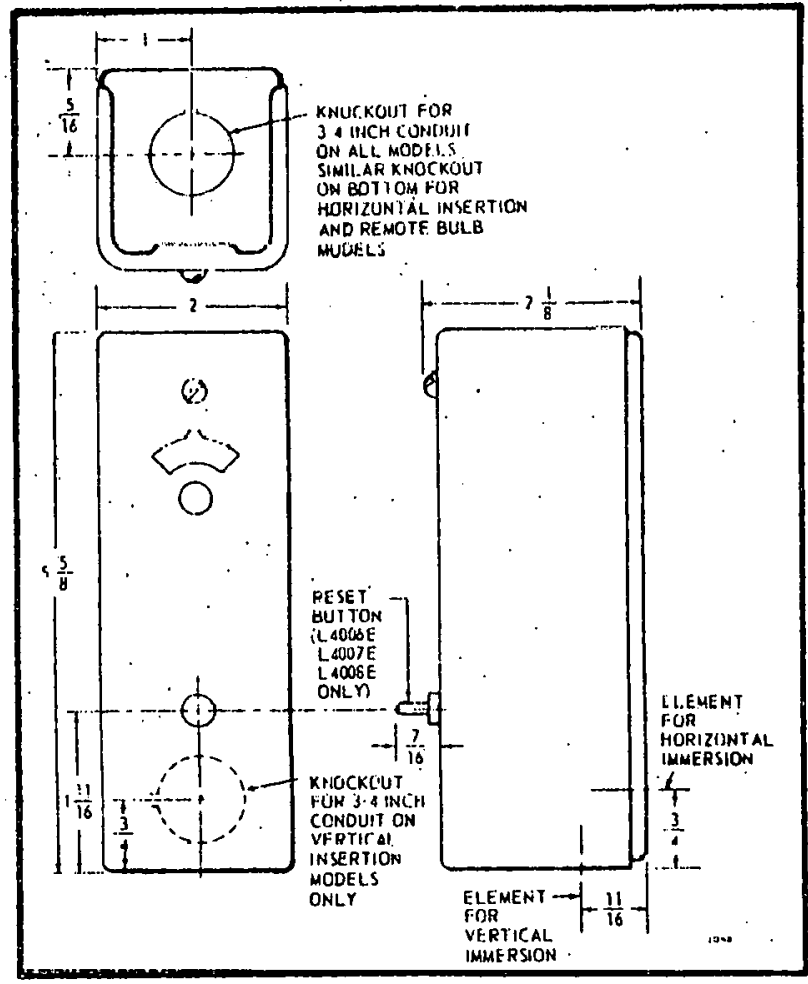

FIG. 1-INSTALLATION DIMENSIONS.

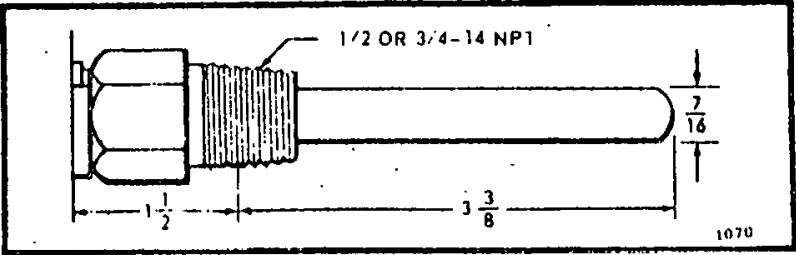

FIG. 3-IMMEASION WELL DIMENSIONS FOR ALL. MODELS EXCEPT L4006C, L4007D. AND L6006B.
ACCESSORIES:

Weatherproof enclosure-Q615.

Immersion wells -

Copper, 1/2 NPT, 1-1/2 Inch Insulation-Part No. $121371 \mathrm{~A}$.

Copper, 1/2 NPT, 3 inch insulation-Part No. $121371 \mathrm{~L}$.

Copper, 3/4 NPT, $1-1 / 2$ inch insulation-Part No. $121371 \mathrm{~B}$.

Copper, 3/4 NPT, 3 inch insulation-Part No. $121371 \mathrm{M}$.

Copper, 3/4 NPT, 1-1/2 Inch Insulation; plastic sleeve-Part No. $12131 \mathrm{~K}$.

Copper, 3/4 NPT, 3 inch insulation; plastic sleeve-Part No. $121371 \mathrm{~N}$.

Stainless steel, 1/2 NPT, 1-1/2 inch insulation - Part No. 121371E.

Stainless steel, $3 / 4$ NPT, 1-1/2 inch insulation -Part No. $121371 \mathrm{~F}$.

Bulb Compression Fittings (see Fis. 6) -

Brass, 1/2 NPT plug. 1-1/2 Inch' insulationPart No. $104486 \mathrm{~B}$.

Brass, 3/4 NPT plug. $1-1 / 2$ inch insulationPart No. $104486 \mathrm{C}$.

Capillary Compression Fittings (see Fig. 7) $\rightarrow$

Copper, 1/2 NPT plug. 1-1/2 inch tosulationPart No. $104484 \mathrm{C}$.

Copper, 3/4 NPT plug. 1-1/2 inch insulationPart No. $104484 B$.

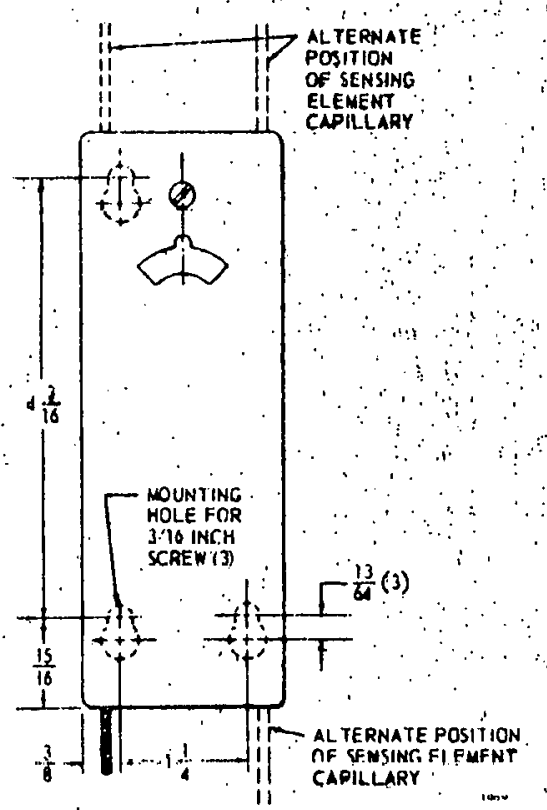

FIG. 2-INSTALLATION DIMENSIONS FOR REMOTE BULB MODELS. OTHER DIMENSIONS SAME AS FIG. 1.

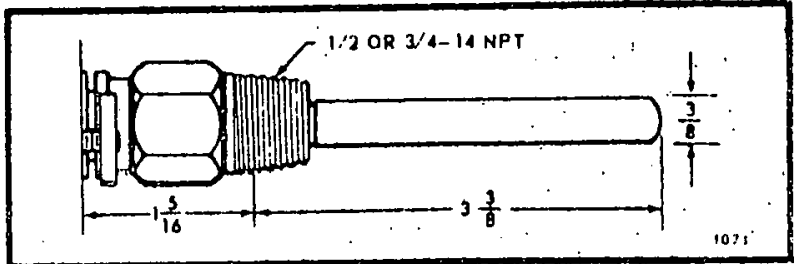

FIG. 4-BOILER FITTING AND BULB DIMENSIONS FOR L4006C L4007D. AND L6006B. 
The manufacturer usually provides a tapping for insertion of the controller's sensing element. This tapping is located at a point where typical water temperature can be measured. Depending on model, the element is inserted in an immersion well, through a boller fitting, or dtreotly immeraed.

Installation should be made by a quallfted serviceman. Follow the instructions furnished by the eystem manufacturer, if avallable. Otherwise, refer to appropriate 'procodure llsted below.

\section{MPORTANT}

Controller may be used with or without inmersion well. Well, if used, must fit sensing bulb snugly for good thermal response. Insert bulb until it rests againat bottom of well, then hold it there while tightening the tubing clamp.

\section{MOUNTING REMOTE BULB MODELS}

The remate temperature-sensing bulb can either be installed in an immersion well (Fig. 5) that extends into the boller or tank, or it can be directly immersed in the liquid. For installations not using a well, secure the remote bulb with a bulb compression fitting (Fig. 6), or capillary compression fitting (Fig. 7).

Well, bulb compression fitting or capillary: compression fitting must be ordered separately. Sizes avallable: $1 / 2$ in., $3 / 4$ in. NPT spud. Well, if used, must fit sensing bulb snugly for good thermal response. Insert bulb until it rests agalnst bottom of well, then hold it there while tightening the tubing clamp. (See.Fig. 5.)

The boiler manufacturer generally provides a tapping for the insertion of the Aquastat controller's sensing element. This tapping should be located at a point where typical water temperature can be measured. The bulb or protecting immersion well must never be located close to a hot or cold water inlet or a steam coll.

If the system is filled, drain system to a point below the boller tapping, or wherever the sensing bulb ts to be installed.

The bulb can also be installed in the supply line of an indirect water heater, in the direct water heater itself, or in the feed riser, about 6 in. above the boller. If the riser is valved, the bulb can be installed between the boller and the valve.

NOTE: Avoid making sharp bends or kinks in the caplllary. Bends should be no sharper than 1 inch radius.

After installing, carefully coll excess capillary at the bottom of the controller case.

\section{IMMERSION WELI MOUNTINO}

1. Screw the well into the boiler, tank, or pipe tapplisy.

2. Insert bulb in well, pushing tubing until bulb bottoms in well.
3. Attach retalner clamp to end of well spud. Loosen draw nut and spread jaws of clamp with screwdriver if necessary.

4. With retalner clamp attached to well opud (be sure jaws of clamp hook over rldge at end of spud, as shown at polnts "A "), edjust tubing to flt through retainer clamp groove, ac ahown pol polnt "B."

5. Tyghten draw nut so that retaines clamp 1 s firm. ly attached to well spud and tubing to hold escurely in place.
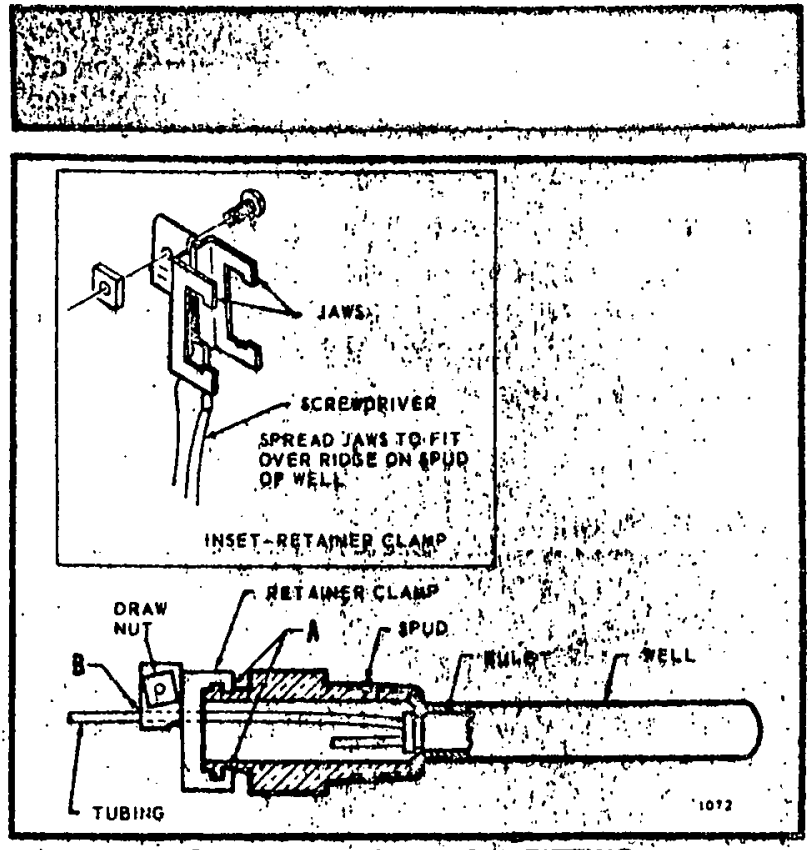

FIQ. 6-1MMESRBION WELL FITTINO.

MOUNTINO WITH RUAA COMPRESSAPA FITHE

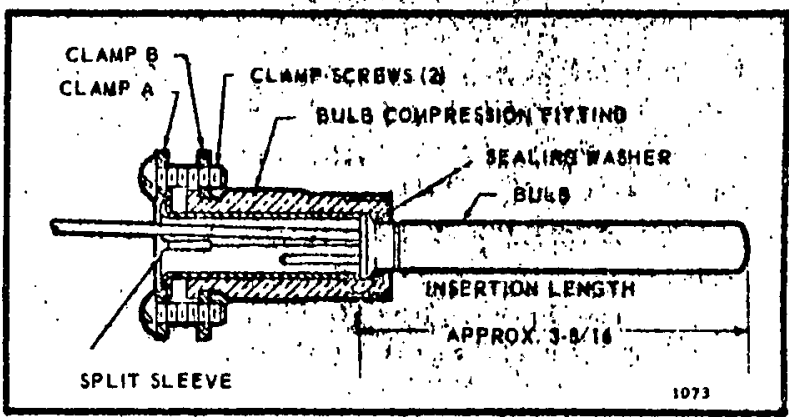

FIG. B-BULB COMPRESSION FITTING: USE WITH MODEL LAOOBA,B,E,J, OR LGO08A.

1. Screw the fitting into bollex or pipe tapping.

2. Slide sealing washer onto bulb.

3. Insert bulb Into bpiler fiftiag until bulb bottoms.

4. Slide split aloeve into fltting.

5. Place clamps A and B on assombly so that sleeve is drawn into fitting when ecrews are tightened. Note: make sure that nub on clamp A ongageg gpace between sleeve and clamp.

6. Tighten clamp вentwa evenly ; : 
MOUNTING WITH CAPILLARY COMPRESSION FITYINO

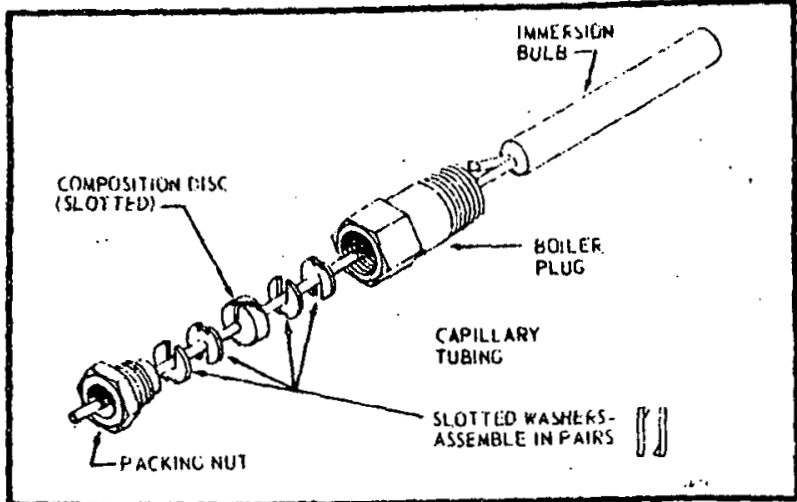

FIG. 7-CAPILLARY COMPRESSION FITTING. USE WITH MODEL LAO08C,D,K, DR !, GOOBC,E.

1. Screw fitting into boiler or pipe tapping.

2. Place packing iut on tubing.

3. Slide hulb completely through fitting.

4. llace compoeition disc and 4 slotted brass washers on tubing in the order shown in Fit. 7. Turn brass washers so that slots are 180 degrees apart.

5. Slide seal assembly into fitting and tighten packing nut.

\section{DUCI MOUNTING}

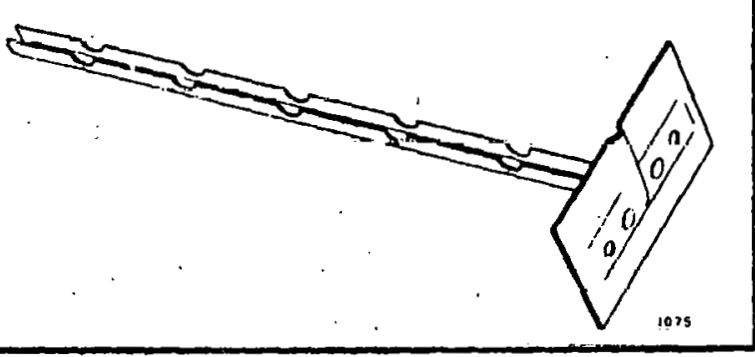

FIG. 8-8ULB SUPPORT.

1. prill a 3/4 inch hole in the duct wall large enough to admit the sensing bulb into the holder.

2. Using the holder as a template, mark and drill holes for bulb holder mounting screws.

3. Break holder to desired length (Fig.9).

NOTE: Holder must be long enough to llold sensing bulb in ireely circulating air away from duct wall. Neatly coil excess capillary at controller case or at bulb holder.

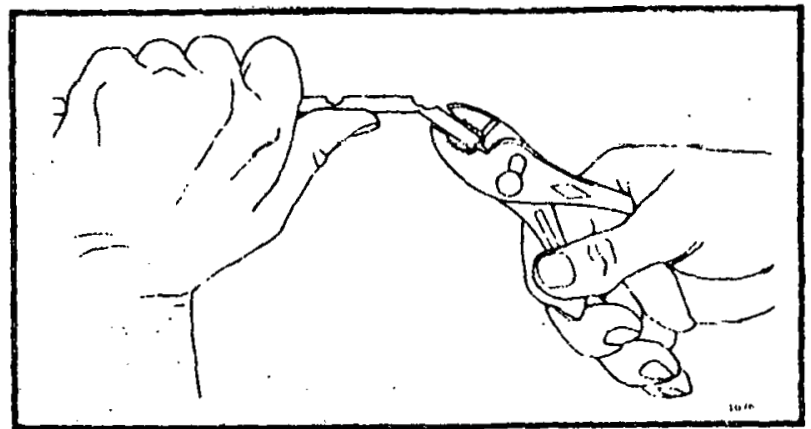

FIG. 9-AEMOVING EXCESS BULB SUPPORT.
4. Place capillary in bulb holder channel. Pinch top edges of holder together at each seginent (Fig. 10).

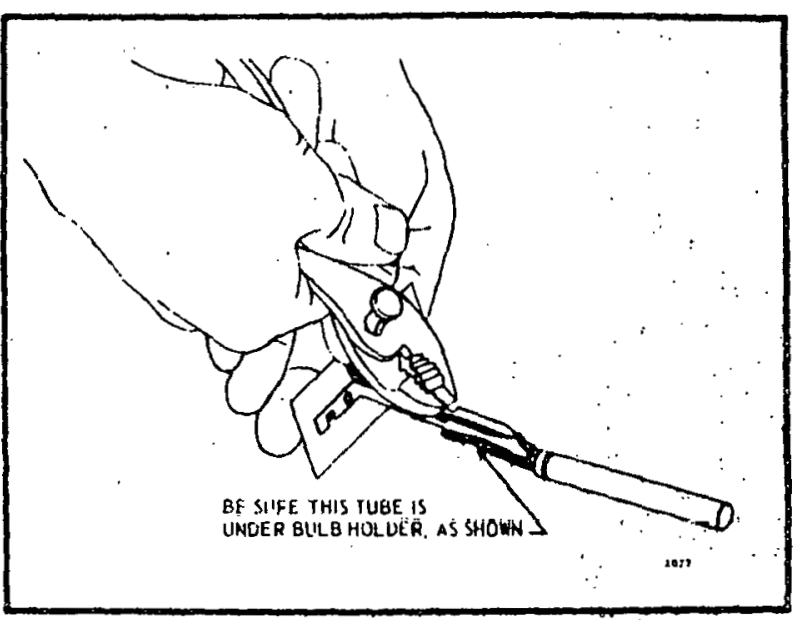

FIG. 10-SECURING CAPILLARY IN BULB HOLDER.

5. Insert bulb holder into controlled area through hole prepared in step 1 above.

6. Fasten bulb holder to duct wall with acrews furnished.

\section{MOUNTING DIRECT IMMERSION MODELS}

\section{FOR MODELS USINO AN IMMERSION WEL}

The well of the Ayuastat controller must always bo exposed to circulation of the medium under. control, but must never be located close to a hot or cold inlet or steam cuil. Where the tapping is on the side of the boller, use an Aguasiat controller with horlzontal well. Where the tapplng is on top of the boiler, use a model with a vertical well.

\section{INSTALLING THE IMMERSION WELL}

On existing installations, shut off the power and remove the old control. If the old immersion well appears suitable, and if the adapter clamp on the Aquatat controller fits the old well spud, the well need not be replaced.

1. If the system is filled, drain gystem to a point below the boiler tapping.

2. Remove plug (or old well) from boiler tapplng.

3. Install the No. 121371 Immersion Well included with the controller. If boiler tapping is greater than $1 / 2$ inch a reduction fitting must be used to adapt the builer opening to the $1 / 2$ inch threads that are standard with the well or fitting. Fittings with $3 / 4$ inch threadr are also available.

4. Fill the system. Make sure that the well Is screwed in tightly enough to prevent leakage. Do NOT tighten or apply force to case after controller is secured to well. 


\section{INSTALLATION OF SENSING BULB IN IMMERSION WELL}

a. Loosen screw (at top of case, above scalesetting), and remove cuver. Loosen two screws that secure adapter clamp. See Fig. 11.

b. Insert the sensing element into the inmersion well.

c. Fasten the case of the Aquastat controller to the well with the adapter clamp. Make certain that the clamp is properly positioned over the groove of the well spud. Also be sure the flange at the opening of the well fits snugly into the opening of the case. The sensing element bulb must bottom in the well.

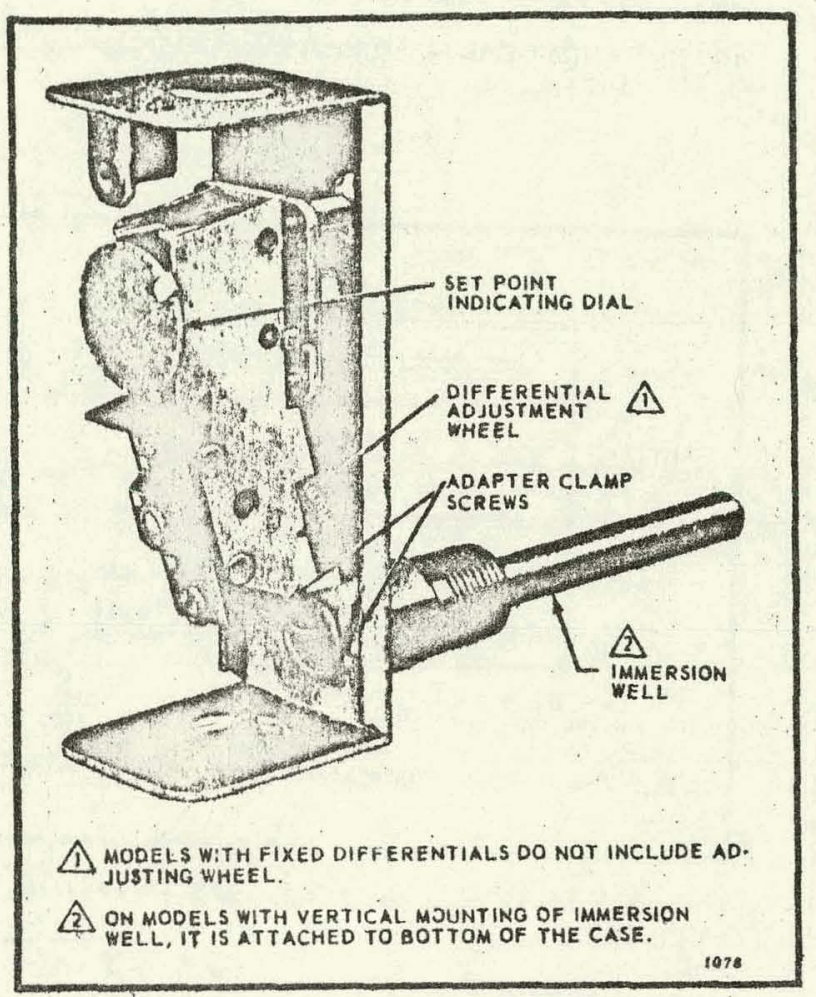

FIG. 11-INTERNAL VIEW OF L6006A.

\section{MOOELS DESIGNED FOR DIRECT IMMERSION (WITHOUT WELL)}

Some models, which provide direct immersion of the sensing element into the boller, Include a No. 104486 bulb compression fitting assembly instead of an immersion well. Install fitting in boller tapping. Be sure sealing washer is in place as shown in Fig. 12. Make sure that spud of bulb compression fltting is Bcrowed in tightly enough to prevent leaking. Insert immersion bulb (sensing element) through bulb compression fitting. Adjust the adapter clamp so that it fits over the groove at the opening of the bulb compression fitting. Tighten adapter clamp screws so that Aquastat controller is firmly attached to bulb compression fitting.

\section{MOUNTING DUAL FUEL CHANGEOVER MODELS}

These models have a five foot capillary. This capillary establishes the maximum distance between the case and the outdoor mounting.

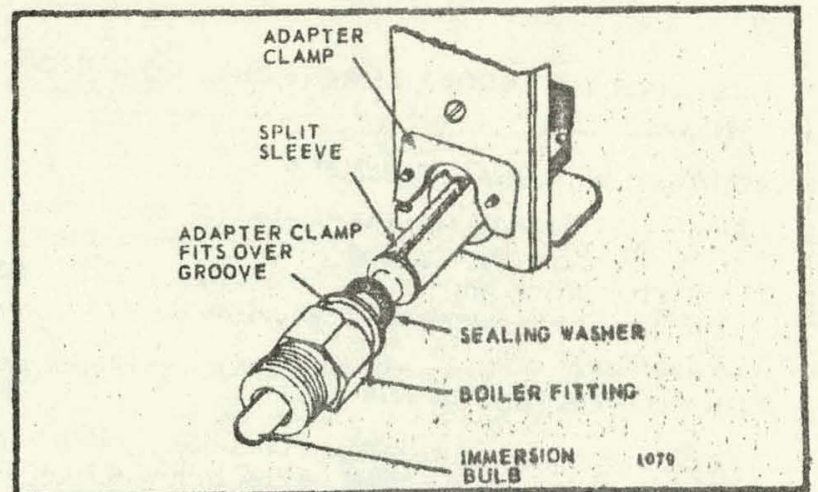

FIG. 12-DIRECT IMMERSION MODEL WITH BULB COMPRES. SION FITTING PARTIALLY REMOVED,

The bulb should be installed on the outside of the building in the shield provided (see Fig, 13) whare it will be exposed to representative air temperature, but not to direct sunlight. It should be mounted high enough so that accumulated smow, leavas, ot other debris cannot obstruct circulation of air around it, and whore children cannot reach it. Avoid vents from the bullding.

Install the case at the indoor location selected, fastening with screws through holes in back of the case. Bring the bulb and tubing out through a $3 / 4$ inch hole in the outstde wall. In unnolling the tubing, carefully avold sharp bends or klnks. Exxcess tublag should be left colled near the case. Do not matre sharp bonde near the casa or bulb.

Slip the bulb through the supports in the shleld. Pinch the split supporting clip until it holds the bulb firmly in position. if the mal-ofe baso protrudes from under the ohield, it may ba bant under as shown in Wig. 13.

Hold the sheld over the mounting position and form a small-radius bend in the tubing. Place the split plug around the tubing and move the shield fato mounting location as a unit. Push the splist plug into the hole until it is wedged securely in plsce." Faston the shteld in place on the wall with the rerews provided.

NOTE: If the tubing 1s properly shaped and the split plug installed as directed, the sheld will cover the split plug, and the hole in the wall will be hidden from sight.

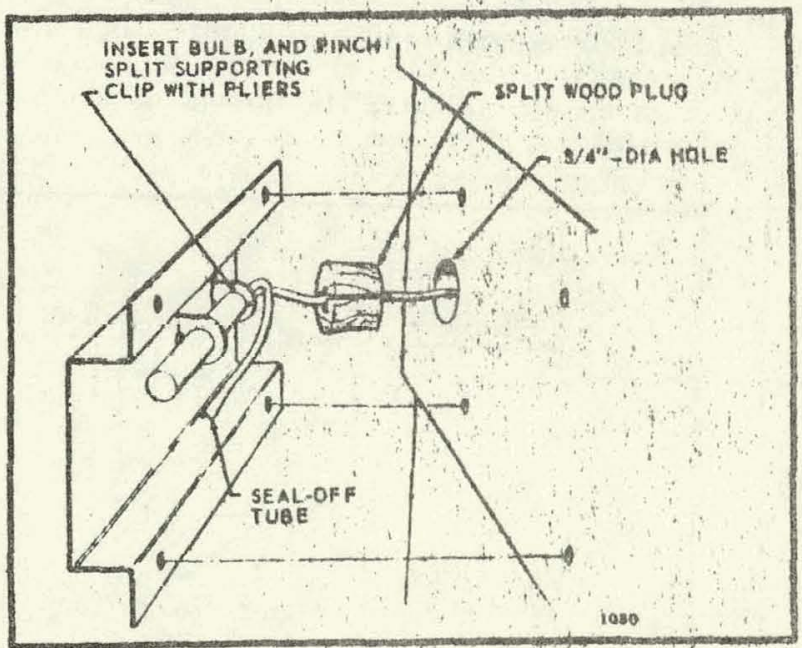

FIG. 13-MOUNTING BULB IN SHIELD OUTSIOE BUILDING. 


\section{MOUNTING THE 16008 A REMOTE BULB COOLING} THERMOSTAT

\section{MOUNTINO WITH OUARD BRACKET}

Mount the bulb in the guard bracket as shown in Fig. 14. Locate the bulb and bracket combination in freoly circulating air in the controlled area. With ocrews provided, fasten the bracket in place.

\section{MOUMTING ON SUCTION LINE}

1. In coaling units with more than one suction line, sensing bulb should be placed on the common line.

2. Make certain the bulb is at least 2 feet from the point at which the suction line leaves the cooler. This will prevent the outside temperature from being transmitted to the remote bulb through the copper tubing of the suction line.

3. Place the remote sensing bulb on the side of the lorizontal suction line between the coil and trap (not on the trap).

4. Attach the sensing bulb to the suction line with clips or straps.

5. Coil the excess length of capillary tubing near the L6008A case.

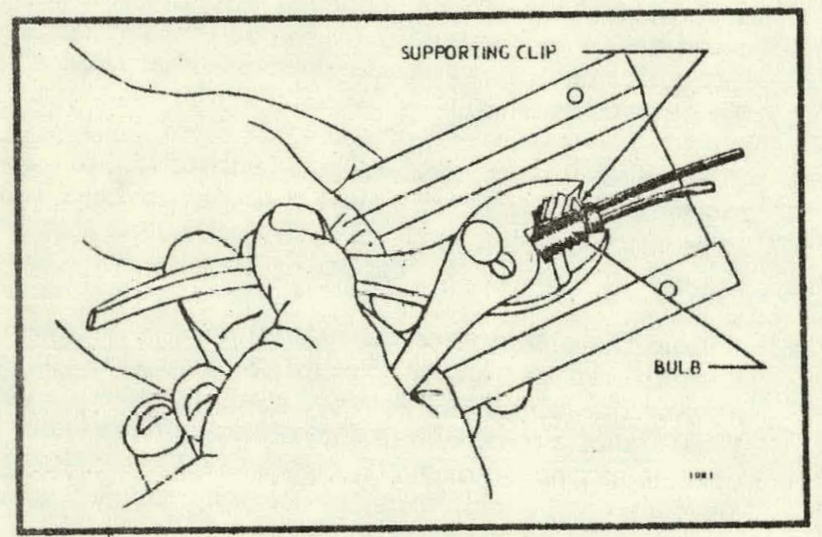

FIG. 14-SECURING REMOTE BULB IN CLIP

\section{WIRING}

All wiring must comply with local codes and ordinances regarding wire size, type of insulation, enclosure, etc. Figures 16 through 23 show typical hook-up diagrams.

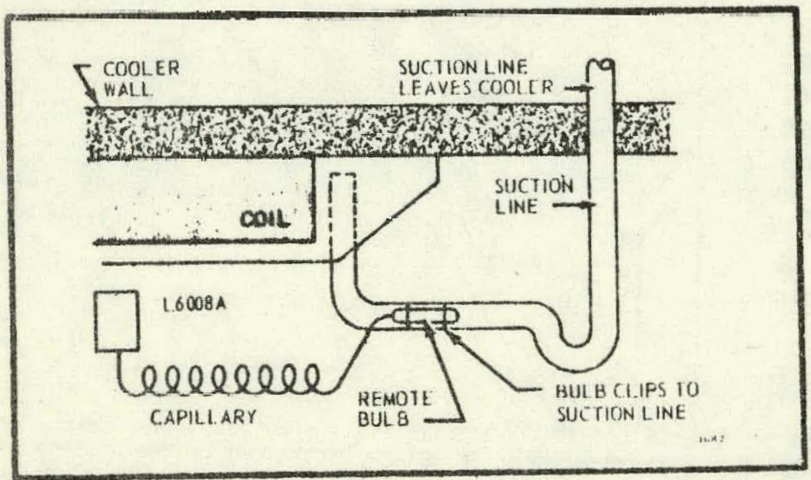

FIG. 15-ATTACHING REMOTE BULB TO HORIZONTAL SUC TION LINE.

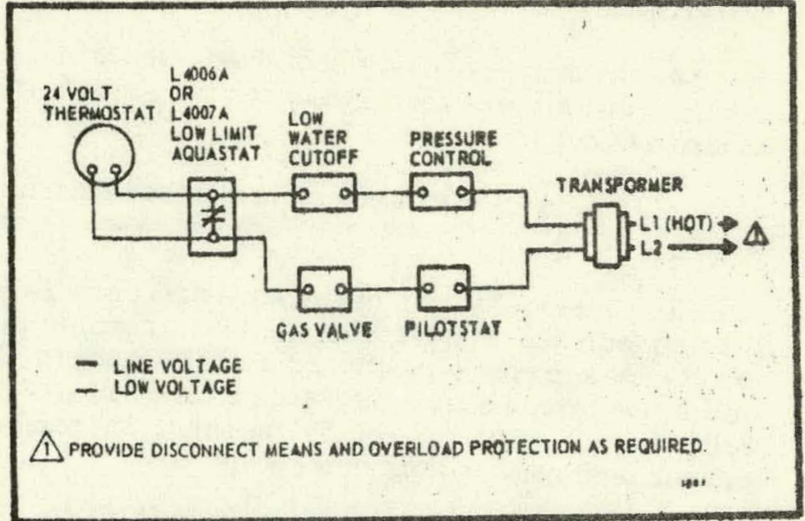

FIG. 16-TYPICAL GAS-FIRED SYSTEM WITH DOMESTIC HOT WATER.

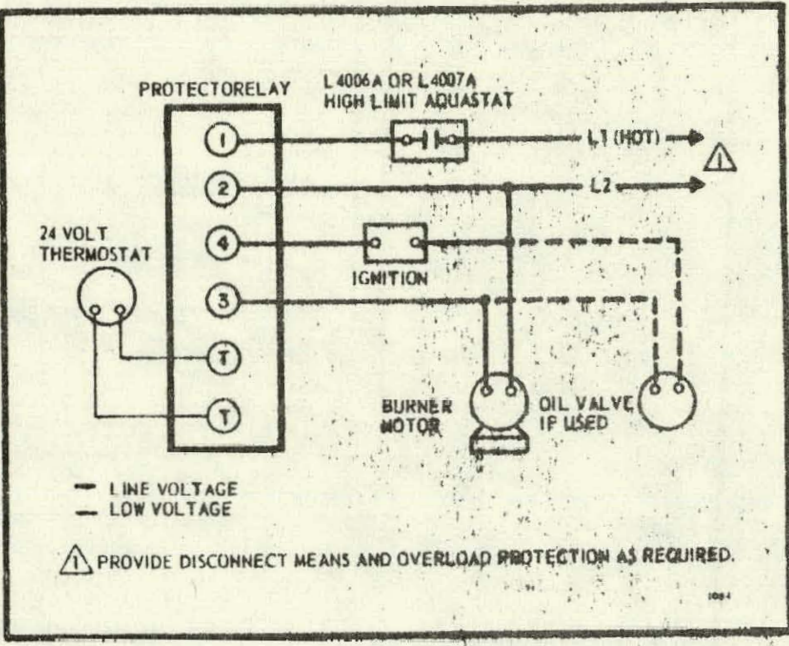

FIG. 17-TYPICAL OIL-FIRED GAAVITY \&YSTEM

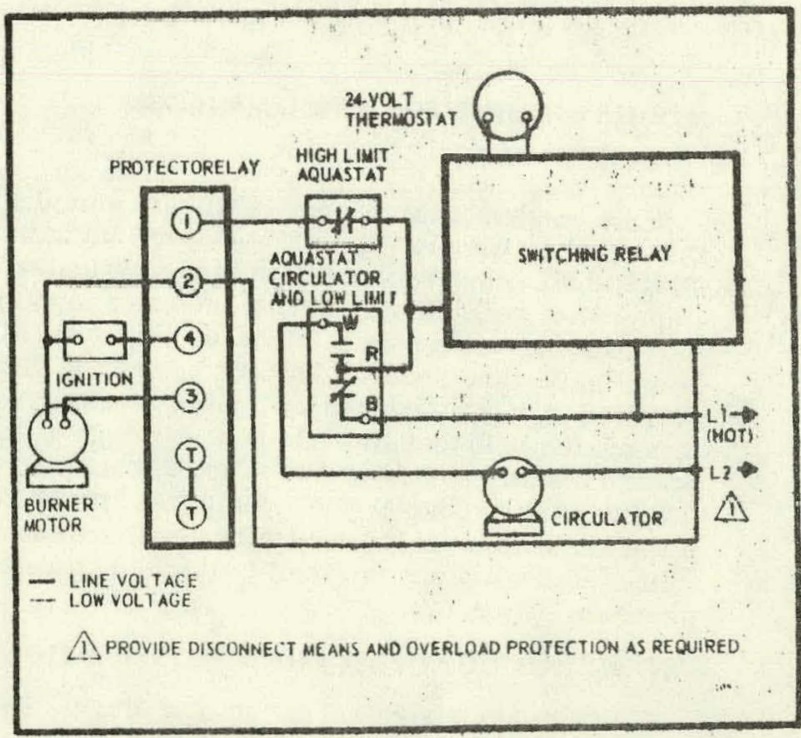

FIG. 18-TYPICAL OIL-FIRED HYDRONIC SYSTEM WITH DO MESTIC HOT WATEA. 


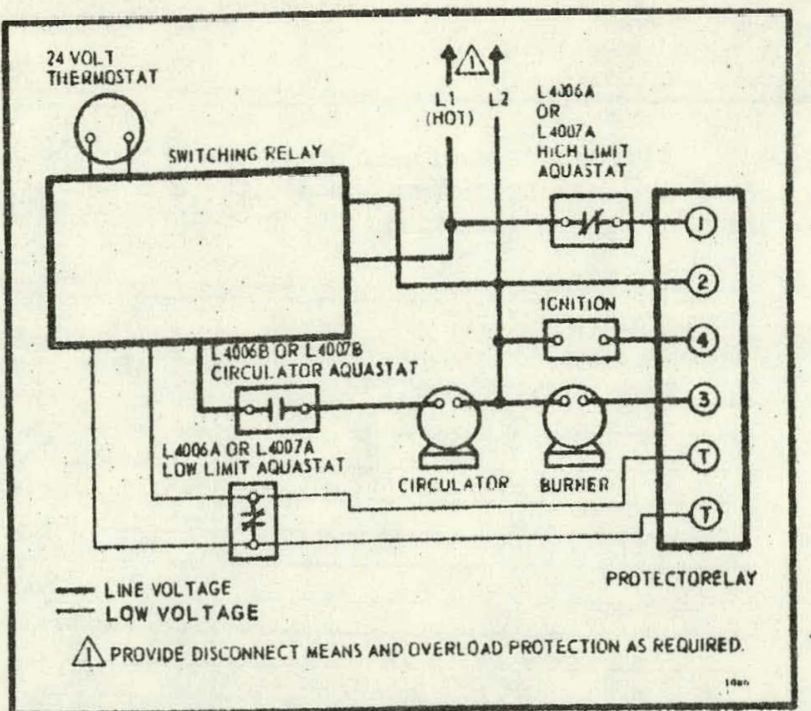

FIG. 19-OIL.FIRED SUMMER-WINTER HYDRONIC SYSTEM WITH DOMESTIC HOT WATER.

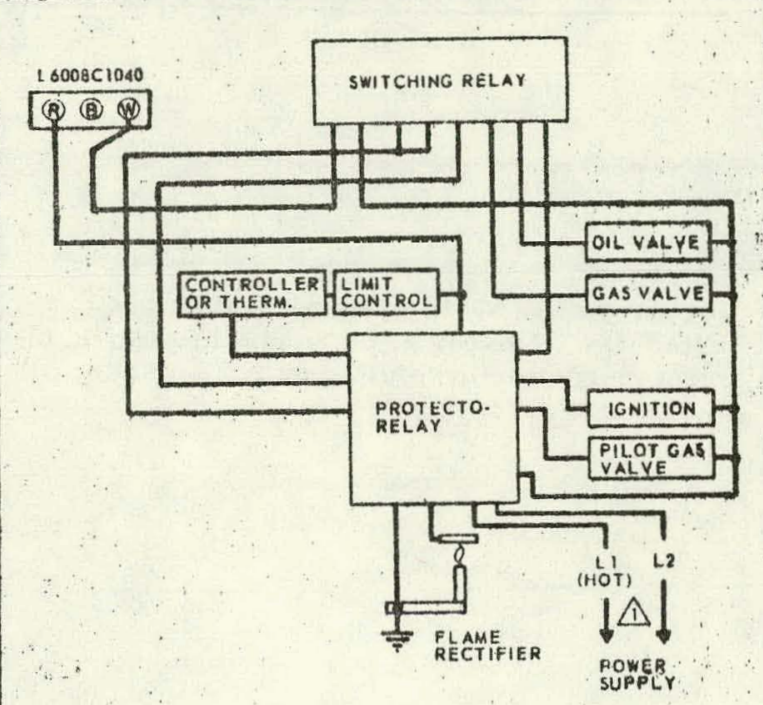
1) PROVIDE DISCONNECT MEANS AND OVERL OAD PROTEGTION
AS REQUIRED.

tae

FIG. 20-TYPICAL WIAING OIAGAAM POR L6008C1040 USED TO SWITCH FROM GAS TO OIL ON TEMPERATURE DROP.

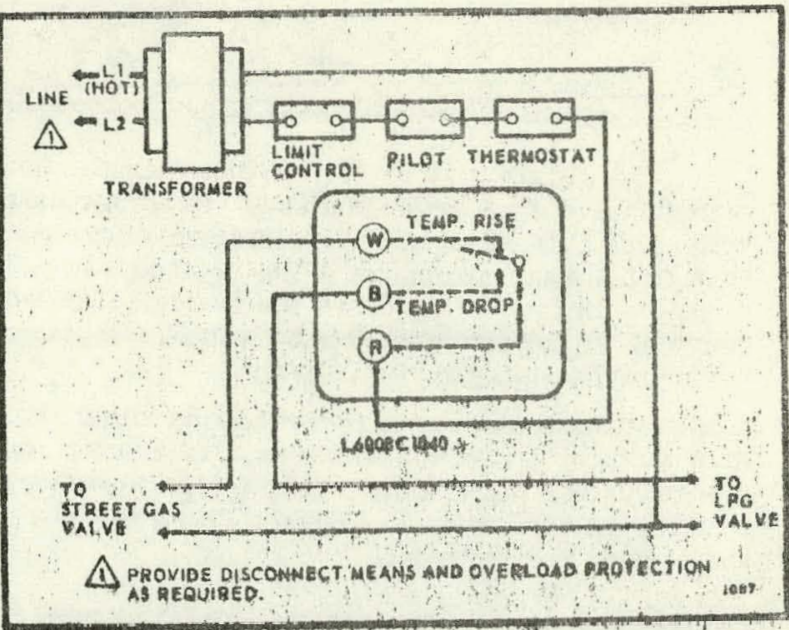

FIC. 21-TVPICAL WIAING DIAGRAM FOM LODOCCIOSD USED TO SWITCH STKEET GAS TO LPS ON TEMPERATURE DRPP.

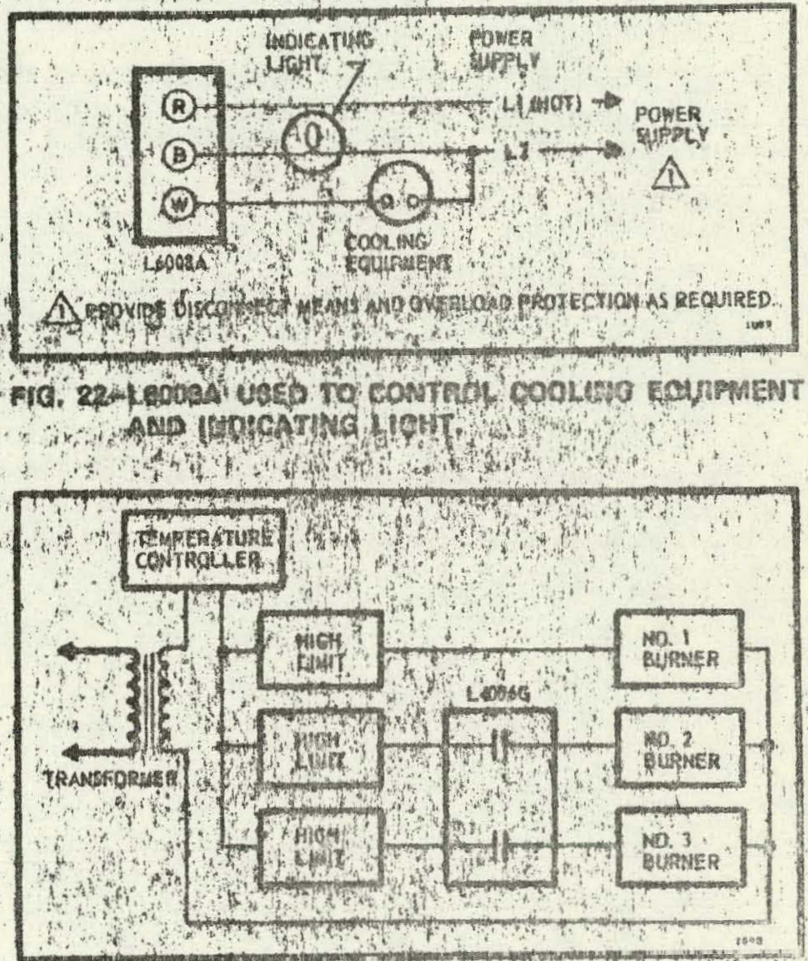

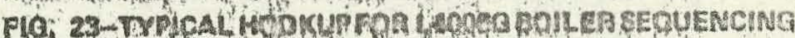

HCYASTIS:

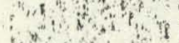

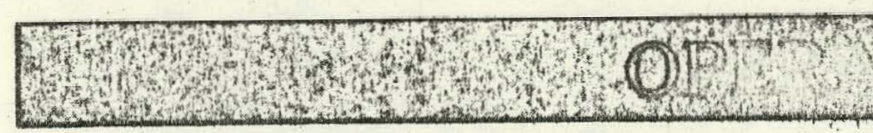

For proper selection of settings, follow the boiler manufacturer's recommendations.

\section{HIGH LIMIT CONTROLLER}

Shuts off burner if water temperature exceeds high limit setting. Burner restarts when temperaturedropa to high limit setting, less differential.

NOTE: On manual reset models, the reset button on the front of the case must be pushed in to allow the burner to operate after a high limit shutdown.

\section{LOW LMIT CONTROMEL}

Maintalng mialmum bollez temperatura tor domestic hat water. Tum on boiler at temperature setting, minus differential in $i$

\section{CIRCULATON COMRRQMLE}

Reventa circulation of wates that is below the desired heating ternperature. Breaks circulator circuit on temperature drap kinlow atting minys differential, remakes on rige to zetting: 
Set the differential to correspond with the boiler manufacturer's recommendations. To adjust models with adjustable differential, rotate the wheel on the back of the enap switch until the desired reading is altgned with the "V" notch in the frame. The wheel provides an adjustment from 5 to $30 \mathrm{~F}$. Replace the cover on the Aquastat controller.

Adjust the control point to correspond with the botler manufacturer' recommendations. To adjust, insert a screwdriver in the slotted screw-type head located beneath the window in the cover. Turn the scale to the desired control point.

\section{L6OOBA LOCAIION DIFFERENTIAL CALIBRATION}

The L6008A1093 is calibrated for applications with both the bulb and case located in the room in which the temperature is being controlled. A correction will be necessary if the temperature of the case is different from the desired dial setting.

1. If the case is at a higher temperature than the desired dial setting, raise the desired dial setting by the correction determined from the table at right.
2. If the case is at a lower temperature than the desired dial setting, lower the desired dial setting by the correction determined from the table below.

\begin{tabular}{c|c}
\hline $\begin{array}{c}\text { Temperature difference between } \\
\text { desired room temperature and } \\
\text { case temperature (F) }\end{array}$ & $\begin{array}{c}\text { Correction } \\
\text { (Degrees F) }\end{array}$ \\
\hline 0 & 0 \\
\hline 5 & $\frac{3 / 4}{1-1 / 2}$ \\
\hline 10 & $\frac{2}{2-3 / 4}$ \\
\hline 15 & $\frac{3-1 / 2}{40}$ \\
\hline 20 & $5-1 / 4$ \\
\hline 30 & 5 \\
\hline 35 & $5-3 / 4$ \\
\hline 40 & $6-1 / 2$ \\
\hline 45 & 7 \\
\hline 50 & 8 \\
\hline 55 & $8-1 / 2$ \\
\hline 60 & 10 \\
\hline 70 & $11-1 / 2$ \\
\hline 80 & \\
\hline & \\
\hline
\end{tabular}

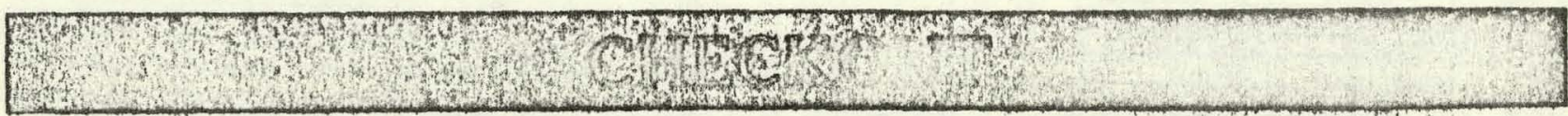

Check to make certain that the Aquastat controller has been installed and adjusted properly. Put the system into operation and observe the action of the device through several cycles to make certain that it provides proper control of the system as described under OP. ERATION. Further adjustments then can be made to meet more exact comfort regulrementi. 


\section{Homeywell}

R8225 Fan Relays provide low voltage control of line voltage fan motors and auxiliary circuits in heating, cooling, or heating-cooling systems.

DHalf inch conduit spud fitting for mounting on junction box.

$\square$ Color coded leadwires for wiring.

Totally enclosed for long, trouble-free service life.

c.s.

$1.76(.028)$
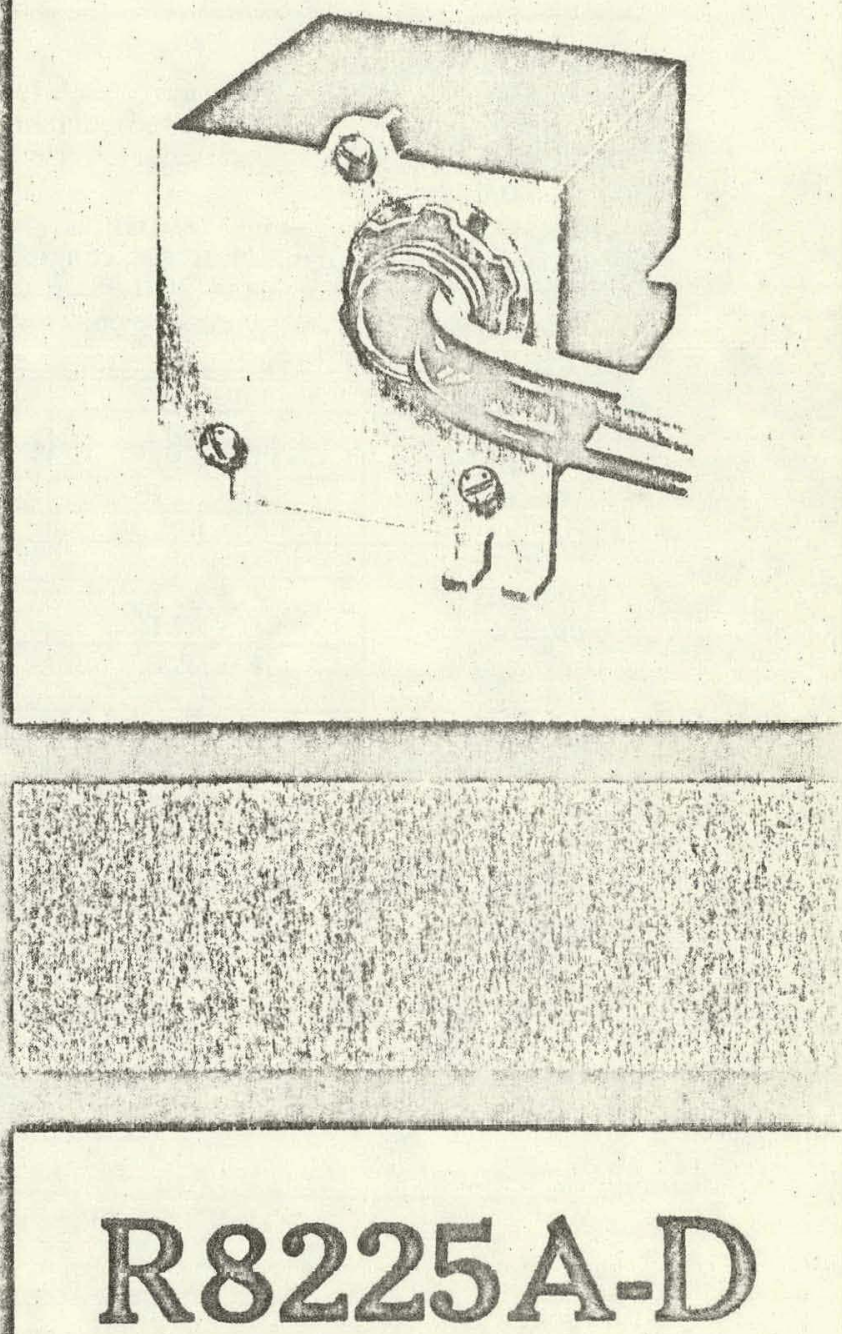


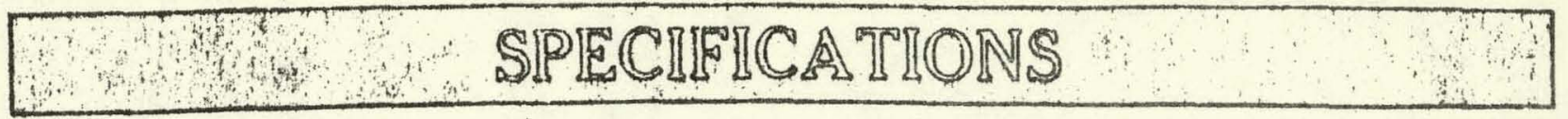

TRADELINE MODELS

Tradeline models are selected and packaged to provide tase of stocking, ease of handling, and maximum replacement value. Tradeline model specifications are the same as those of standard models except as noted below:

TRADELINE MODELS AVAILABLE: R8225A Fan Relay-spdt switching.

ADDITIONAL FEATURES: Tradeline pack with cross reference label and special instruction sheet. Includes flush mounting bracket.
ELECTRICAL RATINGS:

\begin{tabular}{c|c|c}
\hline \hline CONTACTS & $120 \mathrm{VAC}$ & $240 \mathrm{~V} \mathrm{AC}$ \\
\hline \multirow{4}{*}{$\begin{array}{c}\text { Normally } \\
\text { open }\end{array}$} & $1 \mathrm{hp}$ & $1 \mathrm{hp}$ \\
\cline { 2 - 3 } & $16 \mathrm{AFL}$ & $8 \mathrm{AFL}$ \\
\cline { 2 - 3 } & $96 \mathrm{ALR}$ & $48 \mathrm{ALR}$ \\
\hline \multirow{3}{*}{$\begin{array}{c}\text { Normally } \\
\text { closed }\end{array}$} & $16 \mathrm{~A} \mathrm{Res}$ & $8 \mathrm{~A} \mathrm{Res}$ \\
& $3 / 4 \mathrm{hp}$ & $3 / 4 \mathrm{hp}$ \\
\cline { 2 - 3 } & $13.8 \mathrm{AFL}$ & $6.9 \mathrm{AFL}$ \\
\cline { 2 - 3 } & $82.8 \mathrm{ALR}$ & $41.4 \mathrm{ALR}$ \\
\cline { 2 - 3 } & $14 \mathrm{~A} \mathrm{Res.}$ & $7 \mathrm{~A}$ Res. \\
\hline
\end{tabular}

STANDARD MODELS

\section{MODELS:}

R8225A Fan Relay-spdt switching; one normally open and one normally closed contact.

R8225B Fan Relay-spst switching; normally open contacts.

R8225C Fan Relay-dpst switching; one normally open and one normally closed contact.

R8225D Fan Relay-dpst switching; one normally open main and one normally open auxiliary pole.

ELECTRICAL, RATINGS:

\begin{tabular}{|c|c|c|}
\hline CONTACTS & $120 \mathrm{~V} \mathrm{AC}$ & $240 \mathrm{VAC}$ \\
\hline \multirow{4}{*}{$\begin{array}{c}\text { Normally } \\
\text { open }\end{array}$} & $3 / 4 \mathrm{hp}$ & $1 \mathrm{hp}$ \\
\hline & 13, BAFL & 8 AFL \\
\hline & 82.8 ALR & 48 ALR \\
\hline & $16 \mathrm{~A}$ Res. & 8 A Res. \\
\hline \multirow{4}{*}{$\begin{array}{l}\text { Normally } \\
\text { closed }\end{array}$} & $3 / 4 \mathrm{hp}$ & $3 / 4 \mathrm{hp}$ \\
\hline & $13.8 \mathrm{AFL}$ & $6.9 \mathrm{AFL}$ \\
\hline & $82.8 \mathrm{ALR}$ & 41.4 ALR \\
\hline & 14 A Rese & $7 \mathrm{ARes}$ \\
\hline \multirow{4}{*}{ Auxiliary } & $1 / 10 \mathrm{hp}$ & $1 / 8 \mathrm{hp}$ \\
\hline & 3 AFL & $1.9 \mathrm{AFL}$ \\
\hline & $18 \mathrm{ALR}$ & 11.4 AT.R \\
\hline & 3 A Res. & 2 A Res. \\
\hline
\end{tabular}
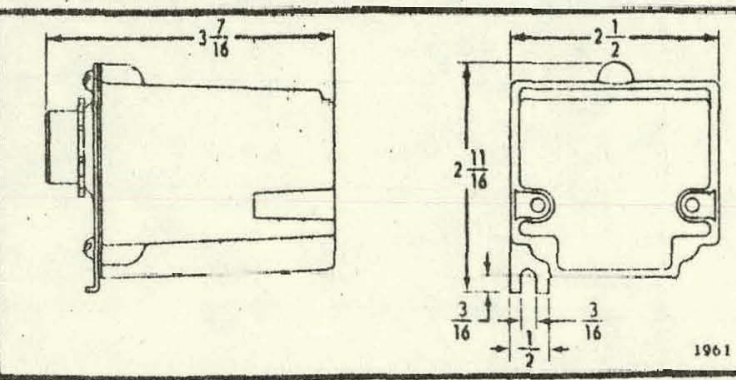

FIG 1-RR225 INSTALLATION DIMENSIONS (IN INCHES).
COIL CHARACTERISTICS:

Coil Voltage $-24 v, 60 \mathrm{~Hz}$.

Inrush-11 va maximum.

Sealed-6 va maximum.

Pull-in voltage $-18 \mathrm{v}$ at 75 percent rated voltage. CONTACTS: Silver cadmium oxide.

MAXIMUM OPERATDNG AMBIENT: $115 \mathrm{~F}$.

CASE: Molded plastic with steel mounting plate.

MOUNTING MEANS: Mounts with threaded $1 / 2$ inch conduit spud.

DIMENSIONS: See Fig. 1.

LISTING BODIES: R8225A-D Fan Relays are listed by Underwriters' Laboratories, Inc. under file number E14480, guide number NLDX, and by the Canadian Standards Association under file 1620. ACCESSORY: Flush mounting bracket 134259. See Fig. 2.
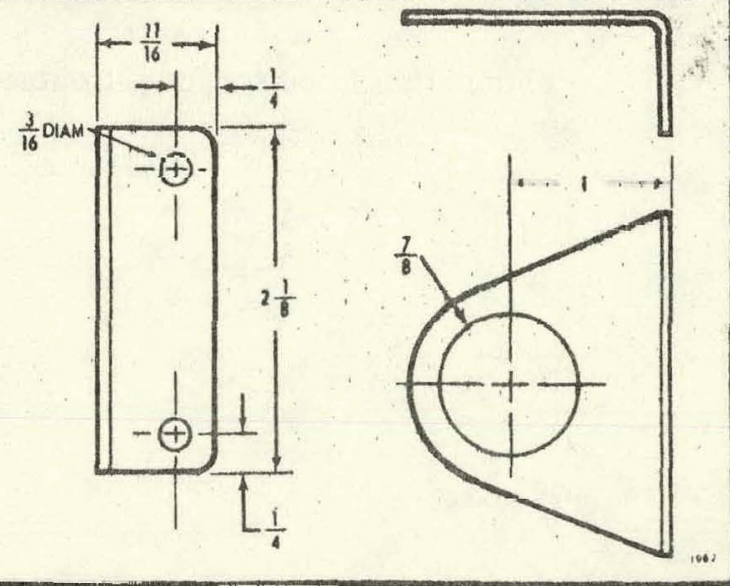

FIG. 2-MOUNTING BRACKET DIMENSIONS (IN INCHES).

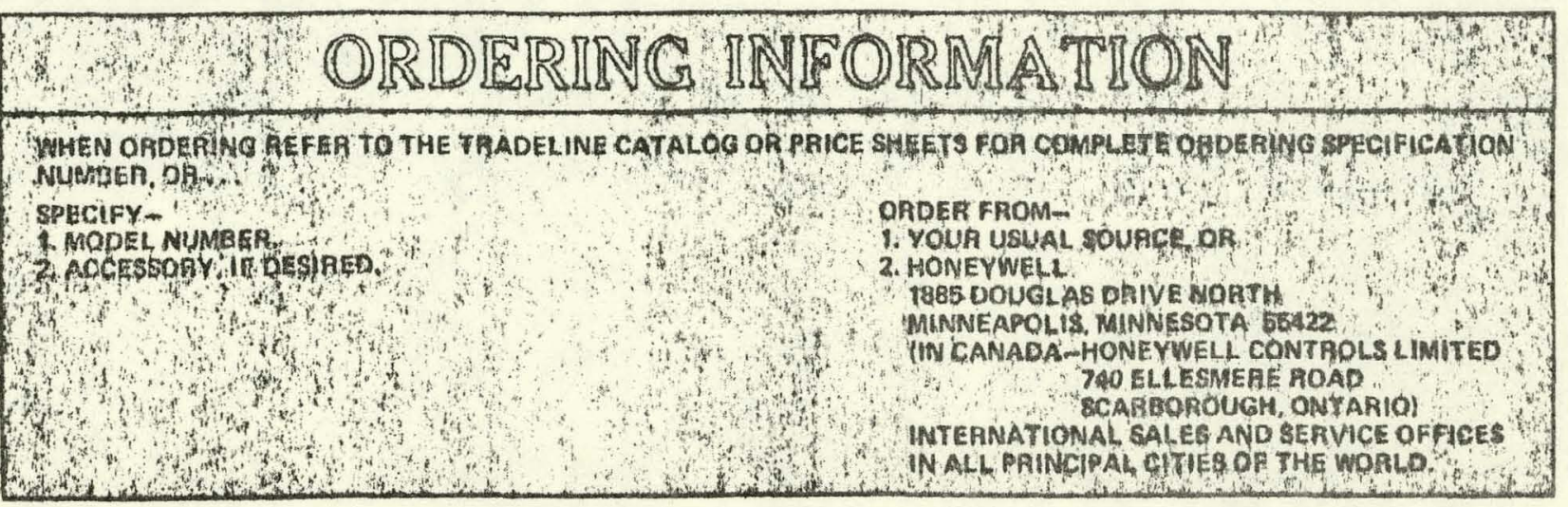


March Circulators are designed for closed and open voiler or domestic hot water systems, and as replacements for hydronic zone valves. Eight models with two capacities are offered. Bronze head pumps are recommended for open systems to resist rust and foreign deposit build-up. Cast iron volutes should be used only on closed circuits where the water is circulated constantly and mineral deposits are minimized.

March's proven magnetic drive eliminates the troublesome, old-fashioned shaft seal. There can be no seal wear, power-robbing friction or leakage thru the seal. Impeller and drive magnets are permanent ceramic type. They prevent slippage and insure that full motor horsepower is con- мотов verted into pumping power.

Energy requirements are lowered as all the energy produced by the motor is utilized, especially important in solar energy systems.

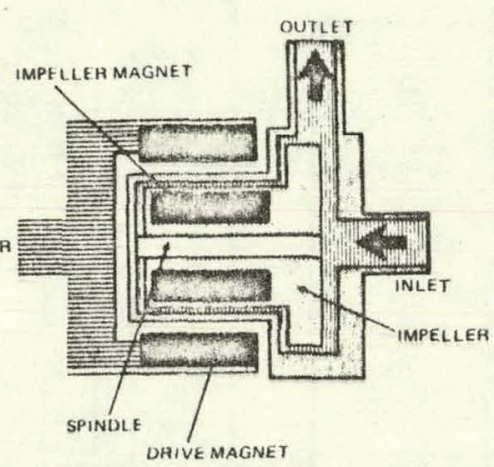

Seal-less drive also provides for faster, easier motor service, as the motor can be removed without draining, refilling and reheating the system.

March circulators are easily installed, either vertically or horizontally, with a choice of standard flanges on the 821 series. Whisper-quiet operation is assured by microbalanced motor fan and dynamically balanced magnets. Just two more reasons why March should be your first choice for most every application!

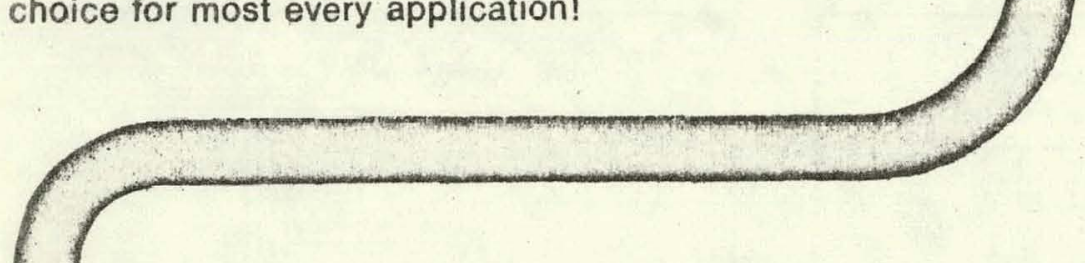

\section{SERIES}

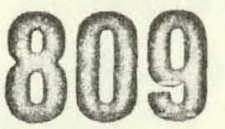

The compact, bronze head Model 809 is ideal for domestic and commercial loops, providing instantaneous hot water at every outlet. Compared with standard circulators, the 3 $\mathrm{gpm} 809$ is smaller, lighter and more economical to buy and operate.

\section{Model 809 DF}

Same as above except equipped with dual fans for quieter, cooler running in closed-in or hot ambients.

\section{Model 809 DF-24}

24 volt version to replace troublesome hydronic zone valves. Eliminates the need for a main boiler circulator.

\section{SERIES \\ (0) 21}

Model 821 is a high capacity, $22 \mathrm{gpm}$, cast iron circulator for closed systems not requiring bronze construction. The March design drastically reduces weight and bulk and costs less than conventional circulators. Common flange sizes of $3 / 4^{\prime \prime}, 1^{\prime \prime}, 1 \frac{1}{4}$, and $1 \frac{1}{2}$ " plus a standard $63 / 8^{\prime \prime}$ flange to flange dimension makes the 821 a perfect replacement pump.

\section{Model 821-BR}

Same as above except for bronze pump head and flanges. The right one for domestic hot water systems.

\section{Model 821-VBR}

Vertical mount bronze unit ideal for hot water heaters and aquastat boosters. 3/4" FPT inlet and outlet are $90^{\circ}$ apart and in a horizontal plane, permitting fast and easy corner installation.

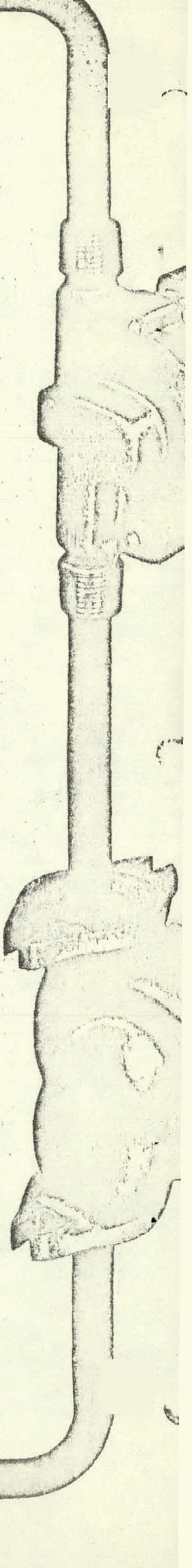


G_ARRAL PURPOSE T-FRAME CAPACITOR MOTORS
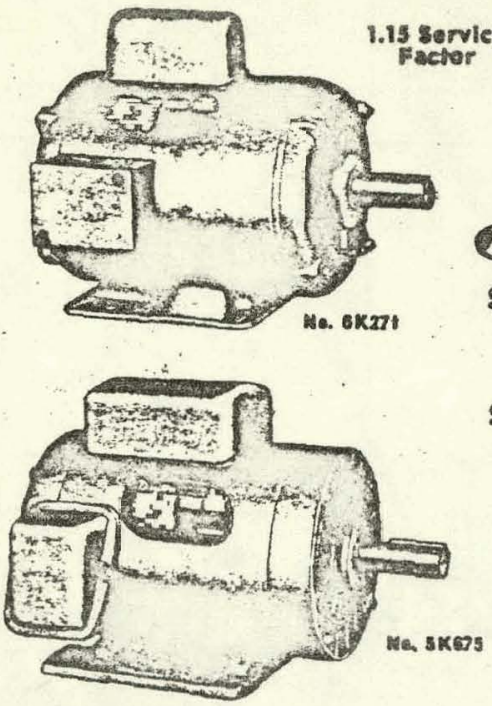

onpropor
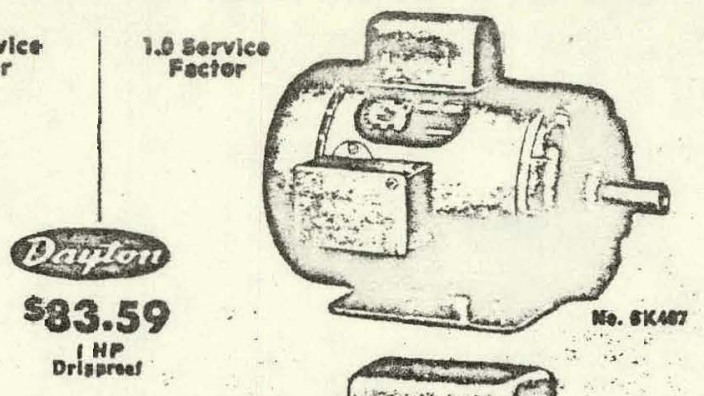

$\$ 91.85$

磊

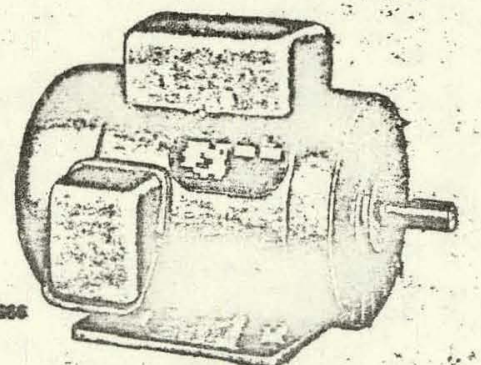

TOTALIY IMCLOSED, FANACOOSD

Built in accordance with the latest NEMA standards. For general purpose applications-pumps, Open, dripprool models; and TRFC motors for operation in dusty, olly, molst locaticns.
Avellable in capacitor-start, induction run and Aapactor-start, capacitor-ran types. 1800 and
cand
3600 RPM, $115 / 20 \mathrm{~s}-230,115 / 230$ and $230 \mathrm{~V}, 80 \mathrm{~Hz}$.

Rigid mount. Pre-lubricated, double-shielded ball bearings. $40^{\circ} \mathrm{C}$ ambient 1.15 or 1.0 service inuous duty. Rotation easily reversed of elec trical reconnection. Recognzzed by ut for constructon under the mor Compont Rec Dayton brand.

\section{I to 10 HP DRIPPROOF NERA T-FRAME MOTORS-RIGID MOUNT} Ball Bearings $60^{\circ} \mathrm{C}$ Risa - 1.15 Service fector - Class 8 Insulation

\begin{tabular}{|c|c|c|c|c|c|c|c|c|c|c|c|c|}
\hline \multirow{2}{*}{$\begin{array}{l}H P \\
1 \\
11 / 2 \\
2\end{array}$} & \multirow{2}{*}{$\begin{array}{l}\text { APM } \\
1800 \\
1800 \\
1800\end{array}$} & \multirow{2}{*}{$\begin{array}{c}\text { Vorts } \\
\text { So Hz } \\
115 / 208-230 \\
115 / 208-230 \\
115 / 230\end{array}$} & \multirow{2}{*}{ 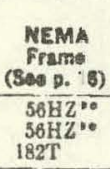 } & \multirow{2}{*}{$\begin{array}{l}\text { Fult- } \\
\text { Lead } \\
\text { Ampas } \\
\text { ara2300 } \\
7.5 \\
10.5 \\
13.5\end{array}$} & \multirow{2}{*}{ 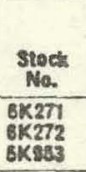 } & \multirow{2}{*}{$\begin{array}{l}\text { Retall } \\
\$ 127.66 \\
160.75 \\
180.00\end{array}$} & \multirow{2}{*}{$\begin{array}{l}\cdot \\
\text { Each } \\
\frac{383.59}{105.28} \\
144.50\end{array}$} & \multirow{2}{*}{$\begin{array}{c}\text { Shos. } \\
\text { Wh. } \\
38 \\
38 \\
62\end{array}$} & \multicolumn{2}{|c|}{$\begin{array}{l}\text { COMPLETE with } \\
\text { MAGNETIC } \\
\text { STATTER } \\
\text { Sra. Ma. ERch. }\end{array}$} & \multicolumn{2}{|c|}{$\begin{array}{l}\text { COMFLETE witt } \\
\text { MARUMG } \\
\text { STARTER } \\
\text { SU. WA. ESeh }\end{array}$} \\
\hline & & & & & & & & & $\begin{array}{l}76297 \\
7 \mathrm{Kag} \\
7 \mathrm{Ka310}\end{array}$ & $\begin{array}{l}9122 \pi \\
18429 \\
300.124\end{array}$ & $\begin{array}{l}7 \mathrm{7} \times 330 \\
7 \mathrm{K331} \\
7 \mathrm{~K} 311\end{array}$ & $\begin{array}{l}\$ 112.7 \% \\
134.45 \\
180.80 \%\end{array}$ \\
\hline $\begin{array}{l}3 \\
71 / 2 \\
0\end{array}$ & $\begin{array}{l}1800 \\
1800\end{array}$ & $\begin{array}{c}115 / 230 \\
230 \\
230 \\
230\end{array}$ & & & & & $\begin{array}{l}193.29 \\
204,00 \\
4 c 350 \\
403,00\end{array}$ & $\begin{array}{r}70 \\
100\end{array}$ & $\begin{array}{l}7 \times 284 \\
7 K 243 \\
7 K C 258\end{array}$ & $\begin{array}{l}259.027 \\
372.43 \\
645.63\end{array}$ & $\begin{array}{l}7 \times 297 \\
7 \times 377 \\
=\end{array}$ & 329.70 \\
\hline
\end{tabular}

I $107 \%$ HP TEPC NEMA T.FRAME MOTORS RIGID MOUNT

Ball Bearings $75^{\circ} \mathrm{C}$ Rise - 1.0 Service Fector - Class B Insulation

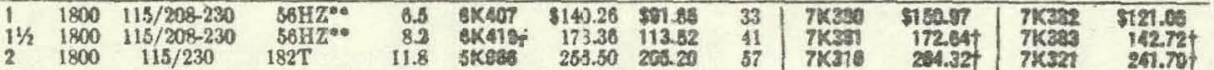

\begin{tabular}{|c|c|c|c|c|c|c|c|c|c|c|c|c|}
\hline & 1800 & $115 / 230$ & $182 \mathrm{~T}$ & 11.8 & 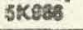 & 253.50 & 205.20 & 87 & $7 \times 316$ & $284.32 \dagger$ & $7 \times 321$ & 261.700 \\
\hline 3 & $\begin{array}{l}3600 \\
1800\end{array}$ & $\begin{array}{l}115 / 230 \\
115 / 230\end{array}$ & $\begin{array}{l}182 \mathrm{~T} \\
184 \mathrm{~T}\end{array}$ & $\begin{array}{l}14.8 \\
14.8\end{array}$ & $\begin{array}{l}\text { exics } \\
8 \times 5807 \%\end{array}$ & $\begin{array}{l}297.00 \\
384.00\end{array}$ & $\begin{array}{l}237.60 \\
286.20\end{array}$ & $\begin{array}{l}65 \\
79\end{array}$ & $\begin{array}{l}7 \times 342 \\
7 \times 317\end{array}$ & $\begin{array}{l}304.024 \\
3221024\end{array}$ & $\begin{array}{l}7 \mathrm{7K} 343 \\
7 \mathrm{~K} 3222\end{array}$ & $\begin{array}{l}274.10 t \\
280.50 \%\end{array}$ \\
\hline 5 & $\begin{array}{l}3600 \\
1800\end{array}$ & $\begin{array}{l}230 \\
230 \\
\end{array}$ & $\begin{array}{l}184 \mathrm{~T} \\
213 \mathrm{~T} \\
\end{array}$ & $\begin{array}{l}22.0 \\
23.0 \\
\end{array}$ & $\begin{array}{l}\text { 6K168 } \\
\text { 5Kosed }\end{array}$ & $\begin{array}{l}4<6.50 \\
4 \leqslant 2.50\end{array}$ & $\begin{array}{l}329.20 \\
354.00\end{array}$ & $\begin{array}{r}88 \\
106\end{array}$ & $\begin{array}{l}7 \times 344 \\
76318\end{array}$ & $\begin{array}{l}97.63 \\
42548\end{array}$ & $\begin{array}{l}7 \mathrm{7} 378 \\
7 \mathrm{KJ74}\end{array}$ & $\begin{array}{l}37.7 \\
403.16\end{array}$ \\
\hline $71 / 2$ & 3600 & $\begin{array}{l}230 \\
230\end{array}$ & $\begin{array}{l}213 \mathrm{~T} \\
{ }_{215 T}\end{array}$ & $\begin{array}{l}32.0 \\
3.10\end{array}$ & $\begin{array}{l}6 \times 179 \\
6 \times 1796\end{array}$ & $\begin{array}{l}523.50 \\
598.50\end{array}$ & $\begin{array}{l}418.20 \\
478.50\end{array}$ & $\begin{array}{l}112 \\
136\end{array}$ & $\begin{array}{l}7 K 439 \\
7 K 346\end{array}$ & $\begin{array}{l}850.92 \\
610.92\end{array}$ & 二 & - \\
\hline
\end{tabular}

(**) Has same shaft and mounting dimensions as : $43 \mathrm{~T}$ and $145 \mathrm{~T}$ frsmes.

(4) Capacitor-start, capacito:-run type; all others, capacitor-stsrt, induction run.

Prices shown are for motors with 115 or $230 \mathrm{~V}$ thermal protecled starters. Specify voltage. Start-atop station (†) Price is stightly higher where $115 \mathrm{~V}$ is opecifisd. (t) Starter available for $230 \mathrm{~V}$ only.

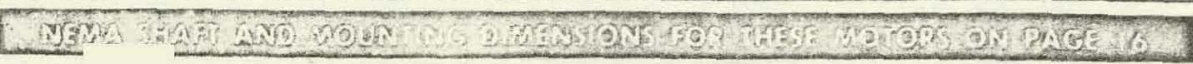

18 NET WHOLESALE PRICES-W.W.GAAINGER, INC.

MEAVY DUTY UFRAME CAPACITOR MNTORS
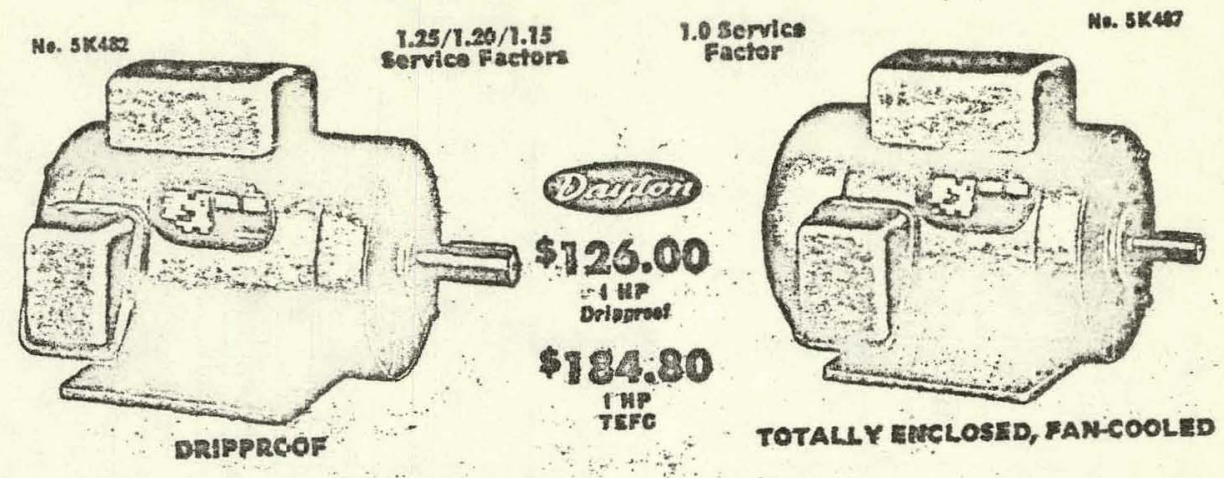

Heavy duty capacitor notors designed and built ( etc. High starting to que with normal starting cooled models for areas where dirt, dust, molscooled models for areas where dirt, dust, mols
ture and other contaminants are present. Ca-
pactitor-start, induction-run type exsept 5 HP units are capacitor-start, capacitor-run. $115 / 230$ and $23 \pi \mathrm{V}, 60 \mathrm{Fz}$. Filgt mount. Pre lubricated, doublest. lelded ball bearings. Cast

alanced rotor for smooth, quiet operation Solld iteel frame. $40^{\circ} \mathrm{C}$ ambient, Class A Insulation ( 40 or $55^{\circ} \mathrm{C}$ rise), continuous duty ${ }^{\circ}$ pen, dripprond 1.15 (3 and 5 HP) service factors; TFFC models, 1.0 service factor. Precision constructed in ac cordance with NGMA mechanical and bor for wiring. gtandards. Large conduit Recognized by UL for
NEMA 182 to 215 frames. Meer
construction under the Motor Component Rec. Ognition Program. CSA
finish. Dayton brand.

I to 5 HP DRPPROOF NEMA U-FRAME MOTORS-RIGID MOUNT Ball Bearings $400^{\circ} \mathrm{C}$ Rise $11.25 / 1.20 / 1.15$ Service Factorst• Class A Insulation

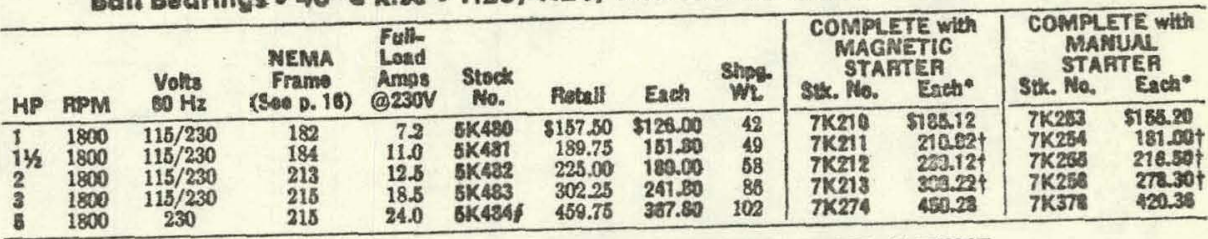

I 5 HP TEFC MEMA URAAAE MOTORS-RIGID MOUNT Dell Boarings - $55^{\circ} \mathrm{C}$ Rise - 1.0 Service Fuctor - Class A Insulation

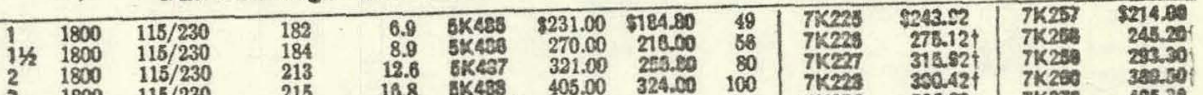

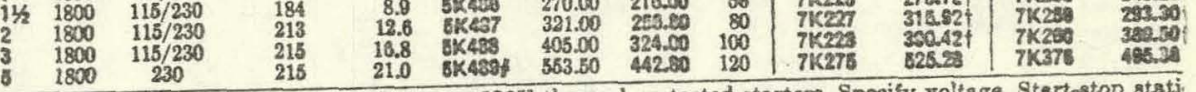
Prices shown are ICr motors with 115 or $230 \mathrm{~V}$ thermal protected starters. Specify voltage. Start-stop statj Peluded with ma gretic Btarters. (t) Price is elightly higher where $115 \mathrm{~V}$ is 8 pecified. 3 and 5 HP, 1.15 .

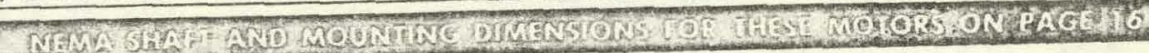

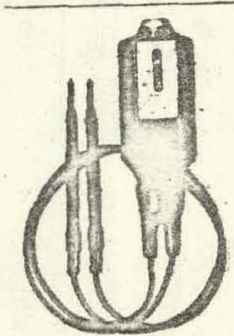

\section{SQUARE D VOLTAGE TESTER}

$110 / 220 / 440 / 550 \mathrm{VAC} 60 \mathrm{~Hz} .125 / 250 / 600 \mathrm{VDC}$

\$1 1.55 Qutckly determines nominal voltage of $\mathrm{DC}$ and $60 \mathrm{~Hz}$ 1.55 circuits. Easy to use, safer and more rugged than many oth retractable shrouds surrounding hardened steel spear points to preve Entire uni: completely sealed in shockproof molded case for operat safery and to protect mechanism from dust, dirt and for ang magne DC poiarity. Individually cartoned. Square D brand (5008). Shpg. wt. 8

Phone the Friendly People at Grainger's-They Can Help You SEI WARRANTY INFORMATION ON PAGE BEFOA. $x$ 


\section{Installation Instructions}

Before proceeding to install Models 344 and $344 \mathrm{~S}$ Blower Unit Heaters, refer to Bryant form No. 39003D1 "Procedures for Gas Appliances" (packaged with the equipment) for information concerning combustion, venting, piping, and other standard installation practices. The current edition of the American National Standard "Installation of Gas Appliances and Gas Piping", Z21.30, takes precedence over all other reference publications pertinent to this installation instruction. Both models are shipped factory-assembled. Installation comprises the following:

* I. Inspection

* II. Location and Suspension

* III. Gas Piping

IV. Wiring

* V. Venting

VI. Start-up and Adjustment

VII. Service and Maintenance

*To perform these sections (or installation steps), refer to the appropriate sections of Bryant form No. 39003D1 (packaged with this equipment).

\section{SPECIAL AIRPLANE HANGAR AND GARAGE APPLICATION PRECAUTIONS}

NOTE: Refer to NFPA No. 409-1969, "Standard on Aircraft Hangars," and NFPA No. 88-1968, "Standard for Garages."

1. A clearance of 10 feet to bottom of Heater from top of a wing or fuselage of aircraft likely to be housed in hangar must be maintained.

2. A minimum clearance of 8 feet from floor to bottom of Heater in other sections of aircraft hangar, such as offices and shops which communicate with areas used for servicing or storage, must be maintained.

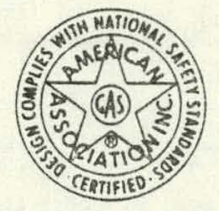

3934401

$11 / 15 / 71$

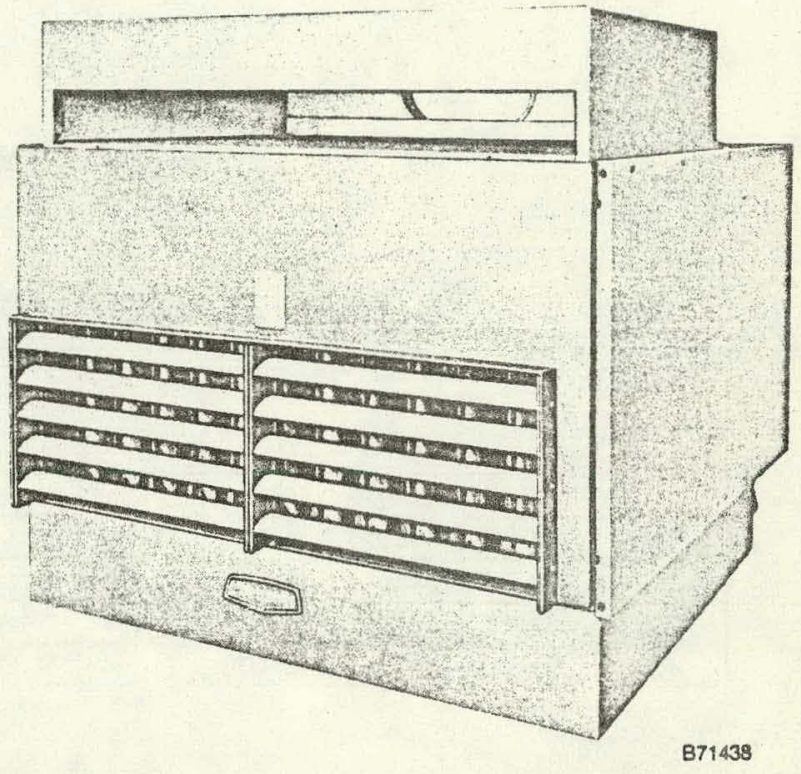

Figure 1

3. Heater must be so located that it is protected from damage by aircraft or other objects such as cranes or movable scaffoldings. In addition, it must be located to be accessible for servicing and adjustment. 4. A clearance of 6 inches from combustible material must be maintained from top and flue connector.

Eighteen inches on each side and 24 inches from any obstruction at bottom of Heater must be maintained.

TABLE I-CONTROL OPTIONS'

\begin{tabular}{|c|c|c|c|}
\hline COMPONENT & $\begin{array}{c}\text { PROPANE GAS } \\
\text { D2 } \\
\end{array}$ & $\begin{array}{c}\text { NATURAL } \\
\text { D4 }\end{array}$ & $\begin{array}{c}\text { NATURAL } \\
\text { DS }\end{array}$ \\
\hline Bryant Auto Pilot & - & $x$ & $x$ \\
\hline Bryant Gas Valve* & $x$ & $x$ & $x$ \\
\hline Gas Pressure Regulator & - & $x$ & $x$ \\
\hline Transformer & $x$ & $x$ & $x$ \\
\hline $100 \%$ Shutoff & $x$ & - & $x$ \\
\hline Themriocouple Pilot & $x$ & - & $x$ \\
\hline Pilot Relay or Pilostat & $x$ & - & $x$ \\
\hline
\end{tabular}

'All three options available on $344 \& 344 \mathrm{~S}$ are available with D2 propane and D5 natural gas only.

-A-643 Bryant Gas Valve with integral Gas Pressure Regulator is used on D4 and D5 for size 150; A.64l Gas Valve withoust regulator is used on D2 for all sizes. A.641 with separate Gas Pressure Regulator is used on D4 and D5 for sizes 200 thru 400.

$$
J-61
$$



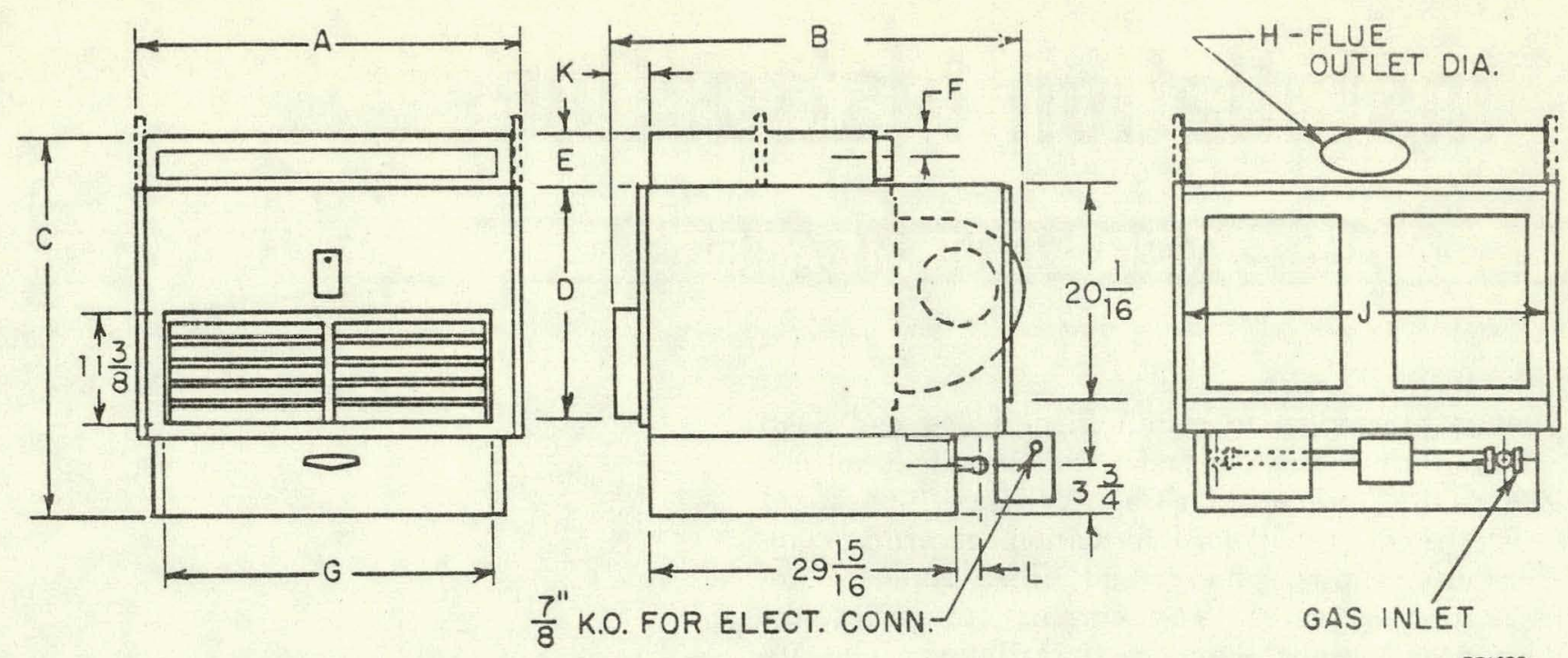

R71396

Figure 2 - Dimensional Drawing

TABLE $\Vdash$-DIMENSIONS IN INCHES-MODEL 344

\begin{tabular}{|c|c|c|c|c|c|c|c|c|c|c|c|c|c|}
\hline Size & A & B & C & D & E & F & G & H & J & K & L & $\begin{array}{c}\text { Gas } \\
\text { Inlet }\end{array}$ & $\begin{array}{c}\text { Approx. } \\
\text { Shipping } \\
\text { Weight }\end{array}$ \\
\hline 150 & $18-1 / 2$ & $44-3 / 16$ & $30-1 / 16$ & $21-3 / 4$ & $5-11 / 16$ & $2-7 / 8$ & $14-3 / 8$ & 7 & 17 & $3-3 / 16$ & $3-7 / 16$ & $1 / 2$ & 215 \\
\hline 200 & $24-1 / 2$ & $44-3 / 16$ & $34-9 / 16$ & $21-3 / 4$ & $5-11 / 16$ & $2-7 / 8$ & $17-3 / 8$ & 8 & 23 & $3-3 / 16$ & $3-7 / 16$ & $1 / 2$ & 280 \\
\hline 250 & $33-1 / 2$ & $44-3 / 16$ & $34-9 / 16$ & $21-3 / 4$ & $5-11 / 16$ & $2-7 / 8$ & $28-3 / 4$ & 8 & 32 & $3-3 / 16$ & $3-9 / 16$ & $3 / 4$ & 380 \\
\hline 300 & $39-1 / 2$ & $44-3 / 16$ & $36-9 / 16$ & $21-3 / 4$ & $7-11 / 16$ & $3-7 / 8$ & $34-3 / 4$ & 9 & 38 & $3-3 / 16$ & $3-9 / 16$ & $3 / 4$ & 465 \\
\hline 400 & $51-1 / 2$ & $44-3 / 16$ & $38-1 / 16$ & $21-3 / 4$ & $9-3 / 16$ & $4-5 / 8$ & $46-3 / 4$ & 10 & 50 & $3-3 / 16$ & $3-5 / 16$ & $3 / 4$ & 625 \\
\hline
\end{tabular}

\section{Specific Location and Suspension Precautions}

For general location and suspension information, refer to Section II of Bryant form No. 39003D1. In addition, the following precautions should be observed when selecting a mounting site.

1. Direct heated airstream toward area having greatest heat loss.

2. For multiple installations, locate Heaters so that each will warm a specific area. Arrange so that overall air pattern results in continuous circular flow of warm air throughout space.

3. Do not locate Heater in areas where combustion air is limited, or is not replaced.

4. If located in spaces equipped with exhaust fans, provide sufficient makeup air to allow proper venting of Heater.

5. Two $1 / 2$-inch pipe tappings are provided in top casing for use in suspending Heater. Use pipe unions to join Unit Heater to ceiling hangar. Two additional 1/2-inch pipe tapped brackets are supplied for balancing Heater.

\section{WIRING}

Make all electrical connections in accordance with the National Electric Code and any local codes that may apply.

If aluminum conductors are to be used, the wire size selected must have a current capacity not less than that of the copper wire specified and must not create a voltage drop between the service panel and the unit in excess of $2 \%$ of the unit rated voltage. As a minimum, aluminum wire must he treated to prevent. oxidation.

With electric power turned off, recheck all electrical connections (both factory and field) for tightness. Be sure to check power supply connections, especially if aluminum conductors are used.

The Blower Unit Heater is completely wired at tho factory and is ready for connections to power sourc See wiring diagram.

The heat anticipator on the thermostat should be set at 0.8 amps. 
TABLE II-THAOW CHART

\begin{tabular}{|c|c|c|c|c|c|c|c|c|c|c|c|c|c|c|c|c|c|c|}
\hline \multirow{3}{*}{ Model } & \multirow{3}{*}{$\begin{array}{l}\text { Velocity } \\
\text { High Speed } \\
\text { ft/min }\end{array}$} & \multicolumn{2}{|c|}{ High Speed } & \multicolumn{2}{|c|}{ Low Speed } & \multicolumn{13}{|c|}{ EFFECTIVE THROW * AND MOUNTING HEIGHT } \\
\hline & & \multirow{2}{*}{ CFM } & \multirow{2}{*}{$\begin{array}{l}\text { Temp } \\
\text { Aise }{ }^{\circ} \mathrm{F}\end{array}$} & \multirow{2}{*}{ CFM } & \multirow{2}{*}{$\begin{array}{l}\text { Tomp } \\
\text { Riso }{ }^{\circ} \mathrm{F}\end{array}$} & \multicolumn{13}{|c|}{ Distance from Floor to Top of Heater in Ft. } \\
\hline & & & & & & 8 & 10 & 12 & 14 & 16 & 18 & 20 & 22 & 24 & 26 & 28 & 30 & 32 \\
\hline $150-344$ & 2100 & 1650 & 65 & 1340 & 80 & 100 & 98 & 95 & 93 & 90 & 88 & 85 & 83 & 80 & 78 & 75 & 73 & 70. \\
\hline $200-344$ & 2100 & 2100 & 67 & 1700 & 85 & 100 & 98 & 95 & 93 & 90 & 88 & 85 & 83 & 80 & 78 & 75 & 73 & 70 \\
\hline $250-344$ & 2100 & 3100 & 60 & 2600 & 70 & 120 & 118 & 115 & 113 & 110 & 108 & 105 & 103 & 100 & 98 & 95 & 93 & 90 \\
\hline $300-344$ & 2100 & 3600 & 60 & 3000 & 70 & 130 & 128 & 125 & 123 & 120 & 118 & 115 & 113 & 110 & 108 & 105 & 103 & 100 \\
\hline $400-344$ & 2100 & 4200 & 67 & 3400 & 85 & 130 & 128 & 125 & 123 & 120 & 118 & 115 & 113 & 110 & 108 & 105 & 103 & 100 \\
\hline
\end{tabular}

*Effective throw as shown is the horizontal distance in feet that the heated airstream travels from the outlet of the unit heater with louvers positioned for maximum throw with air reaching the floor. Spread or width of the air pattern is approximately $20 \%$ of the maximum throw. For additional spread, use vertical louvers. Above data are test results.

\section{START-UP AND ADJUSTMENT}

1. Start unit using procedure outlined on lighting instruction plate attached to Heater.

2. Adjust pilot flame. Use adjusting screw under screw cap on pilot valve for this purpose.

For D4 controls, flame should be long enough for good impingement on metal element of Bryant automatic pilot. For D5 and D2 controls, flame should surround thermocouple element of pilot and extend downward to include $3 / 8$ to $1 / 2$ inch of thermocouple. Flame should never come in contact with any other part of thermocouple or its lead wire.

To adjust pilot flame on units equipped with a Model A-643 valve, adjustment screw is located in pilot outlet portion of valve body. Remove capscrew, make necessary adjustment, and replace capscrew.

3. Cherk input.. Innut shnuld he checked at meter to make sure that it corresponds with input shown on rating plate attached to unit. See Bryant form No. 39003D1 for method.

4. Final Checkout. Move thermostat setting above and below room temperature several times, pausing between each "on" and "off" cycle to make sure that main burners ignite properly.

Attach a low-voltage test light to electrical leads of gas valve. With thermostat set above room tem. perature, close manual pilot valve. If light goes out when pilot cools, pilot is functioning properly. The test light should go out within $\mathbf{4 5}$ seconds after pilot gas supply is turned off.

Check the operation of temperature limit control. This can be done by allowing burners to operate while fan is not running to see that limit switch opens.

Check all connections in the gas piping for leaks. Use a soap-and-water solution.

WARNING: Never use a flame to check for leaks.

\section{SERVICE AND MAINTENANCE}

1. Pilot Orifice - is located in bottom fitting of pilot and is readily accessible for inspection and cleaning.

2. Main Burner Orifices - The orifice is readily unscrewed from manifold after burner is removed:

3. Removing Main Burners - Lift rear of burner and push it away from manifold enough to disengage orifice spud from mixer shield. Then pull down and out of Heater. End of burner away from manifold seats in a slotted burner support. It is necessary to lift burner out of this slot before attempting to push burner back. See Figure 8.

NOTE: Disconnect the pilot tubing and wires to remove the burner that holds the pilot. However, it is not necessary to remove the pilot itself from the burner.

4. Cleaning - Heat exchanger tubes should be inspected at regular intervals and cleaned when necessary.

a. Shut off gas and electricity. Heater should be cool.

b. Disconnect pilot tube and wires.

c. Remove main burners and pilot.

d. Use stiff brush to scrub heat exchanger tubes. Remove all loose scale and any soot that may have collected.

e. Replace burners and pilot. Reconnect pilot tube and wires.

f. Unit is now ready for relighting.

5. Oiling-direct-drive sleeve-bearing blower motors are prelubricated and normally will not need further oiling for approximately 5 years. Lubricating then should be performed by an experienced serviceman as blower assembly will have to be disassembled.

Each sleeve bearing on above motors should be oiled with 25 drops of SAE 20 nondetergent motor oil annually after 5 years. Avoid over-oiling. 


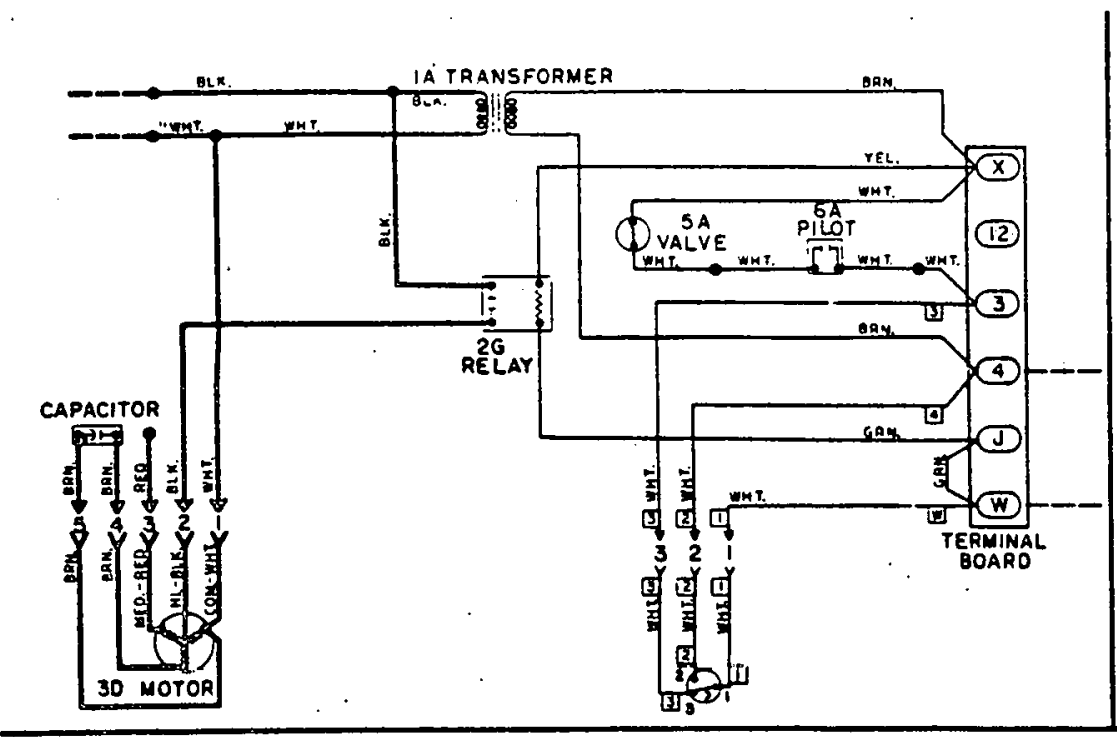

IF ANY OF THE ORIGINAL WIRE AS SUPPLIED WITH THE APPLIANCE MUST BE REPLACED, IT MUST BE REPLACED WITH TYPE SFF-2 150C FOR 24-VOLT CIRCUITS AND APPLIANCE WIRING MATERIAL IOSC FOR LINE VOLTAGE CIRCUIT3.

THIS UNIT IS APPROVED FOR 0.25 WC STATIC $55^{\circ} \quad$ FACTORY LINE VOLTAGE TO $85^{\circ}$ RISE, SEE INSTALLATION INSTRUCTIONS OR - FACTORY LOW VOLTAGE APPLICATION MANUAL BEFORE CHANGING SPEED - - FIELD LINE VOLTAGE TAPS OR ADDING OUCTWORK.

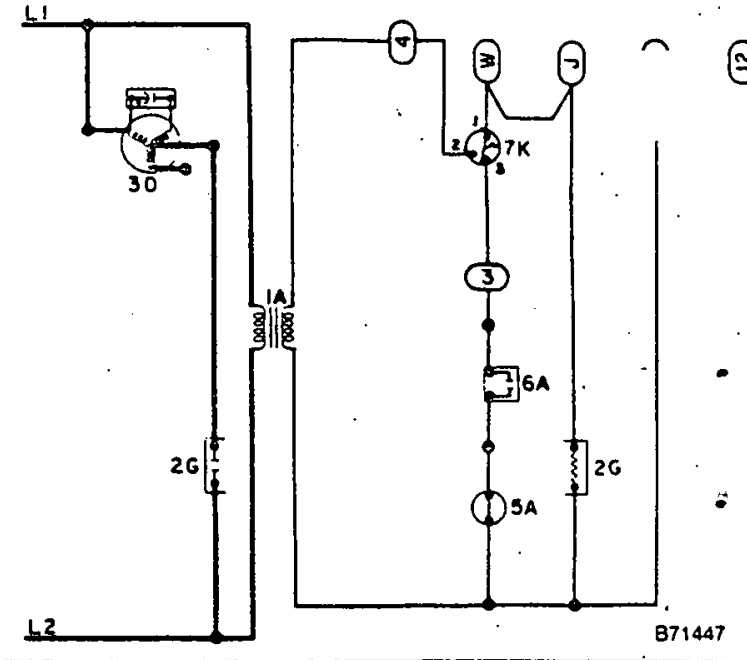

1A.TRANSFORMER

2G-BLOWER RELAY 3D-BI.OWFR MOTOR SA-HEAT MOIOR VALVE 6A.PILOT SWITCH (OMIT ON PROPANE) 7K-TEMPERATURE LIMIT CONTROL

Figure 3 - With 732 Pilot Installed Non 100\% Shutof, Nat. Gas (D4)

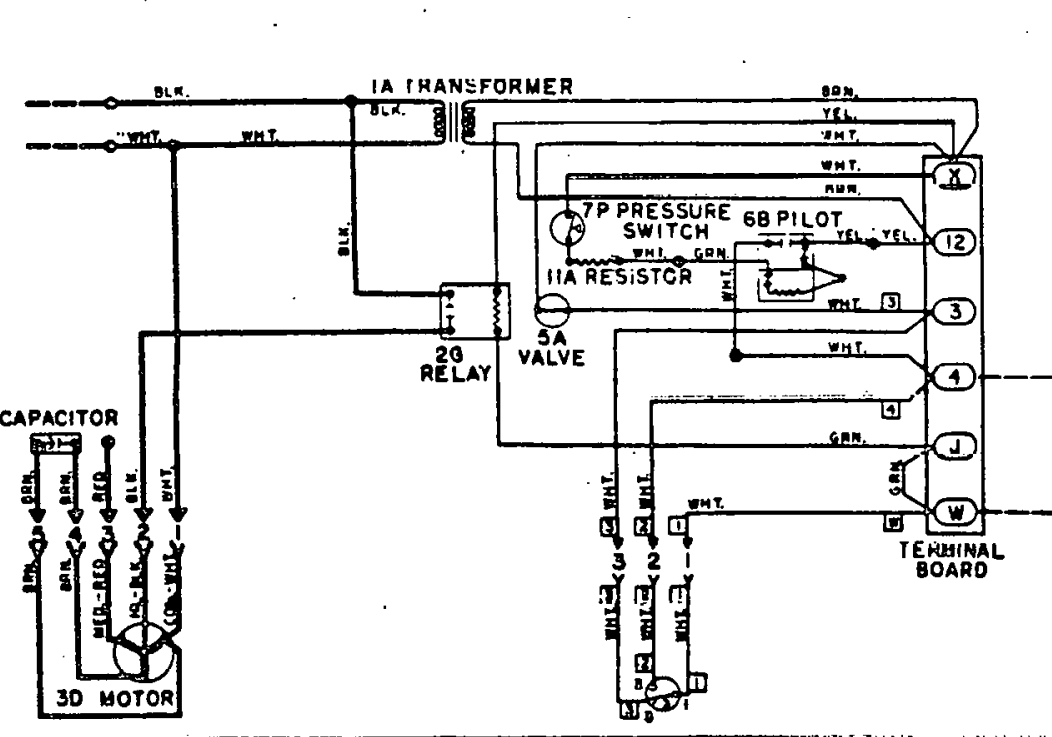

IF ANY OF THE ORIGINAL WIRE AS SUPPLIED WITH THE APPLIANCE MUST, BE REPLACED, IT MUST BE REPLACED WITH TYPE SFF-2 $150 \mathrm{C}$ FOR 24-VOLT CIRCUITS AND APPLIANCE WIRING MATERIAL 105C FOR LINE VOLTAGE CIRCUITS.

THIS UNIT IS APPROVED FOR 0.25 WC STATIC $55^{\circ}$ TO $85^{\circ}$ RISE, SEE INSTALLATION INSTRUCTIONS OR APPLICATION MANUAL BEFORE CHANGING SPEED TAPS OR ADDING DUCTWORK.
FACTORY LINE VOLTAGE

- FACTORY LOW VOLTAGE

- - FIELD LINE VOLTAGE

- - FIELD LOW VOLTAGE
1A.TRANSFORMER 2G-BLOWER RELAY 3D-BLOWER MOTOR 5A-HEAT MOTOR VALVE 6B-733 PILOT (REIGNITION) 7K-TEMPERATURE LIMIT CAATROL 7P.PRESSURE SWITCH SP: 11A-RESISTOR

Figure 4 - With 733 Pilot Installed Automatic Electric Reignition (D1)

$$
J-\frac{1}{64}
$$




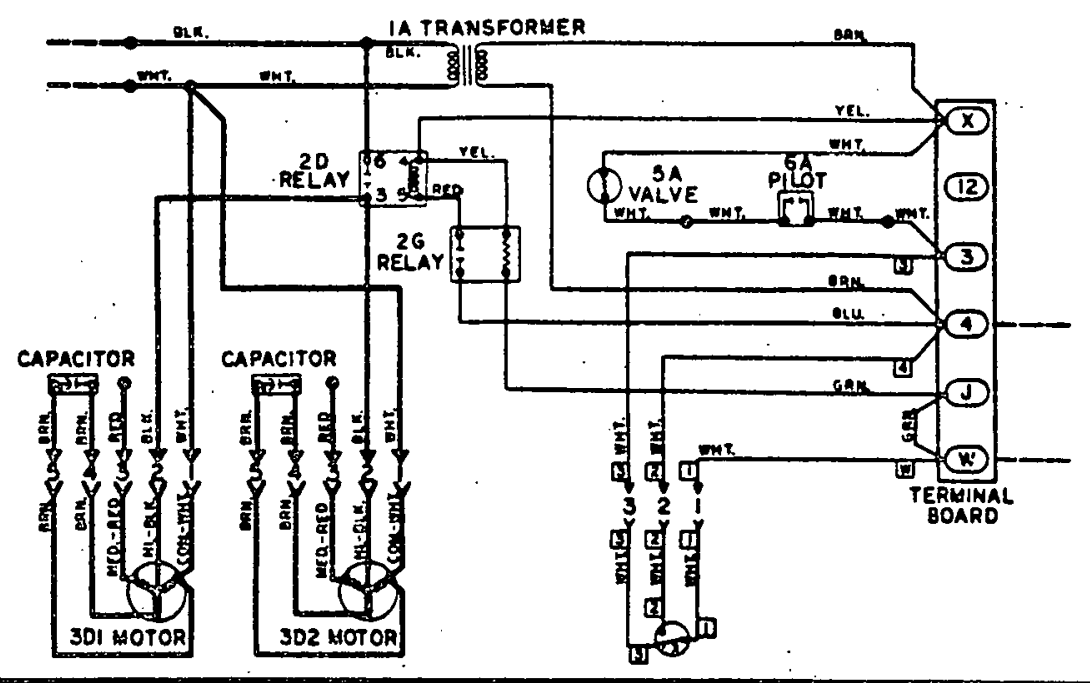

IF ANY OF THE ORIGINAL WIRE AS SUPPLIED WITH THE APPLIANCE MUST BE REPLACED, IT MUST BE REPLACED WITH TYPE SFF.2 $150 \mathrm{C}$ FOR 24-VOLT CIRCUITS AND APPLIANCE WIRING MATERIAL 105C FOR LINE VOLTAGE CIRCUITS.

THIS UNIT IS APPROVED FOR 0.25 WC STATIC $55^{\circ} \longrightarrow$ FACTORY LINE VOLTAGE TO $85^{\circ}$ RISE, SEE INSTALLATION INSTRUCTIONS OR FACTORY LOW VOLTAGE APPLICATION MANUAL BEFORE CHANGING SPEED - - FIELD LINE VOLTAGE TAPS OR ADDING DUCTWORK.

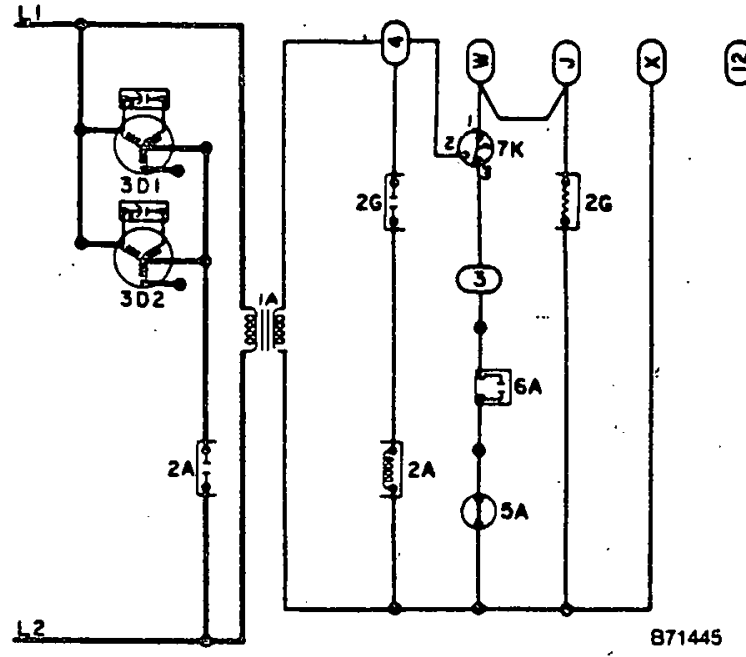

1A-TRANSFORMER 2A-BLOWER RELAY 2G-HEAT-MOTOR-OPERATED RELAY 3D1\&2-BLOWER MOTOR 5A-HEAT MOTOR VALVE 6A-PILOT SWITCH (OMIT ON PROPANE: 7K-TEMPERATURE LIMIT CONTROL

Figure 5 - With 732 Pilot Installed Non 100\% Shutoff, Nat. Gas (D4)

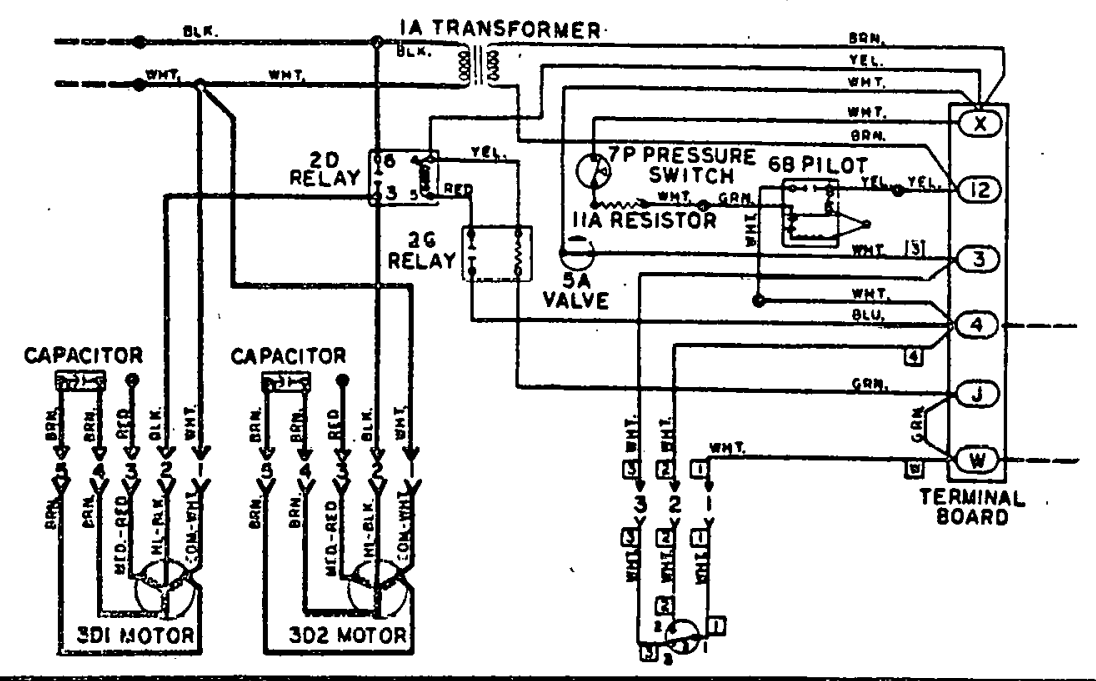

IF ANY OF THE ORIGINAL WIRE AS SUPPLIED WITH THE APPLIANCE MUST BE REPLACED, IT MUST BE REPLACED WITH TYPE SFF-2 150C FOR 24-VOLT CIRCUITS AND APPLIANCE WIRING MATERIAL 105C FOR LINE VOLTAGE CIRCUITS.

THIS UNIT IS APPROVED FOR 0.25 WC STATIC $55^{\circ}$ TO $85^{\circ}$ RISE, SEE INSTALLATION INSTRUCTIONS OR APPLICATION MANUAL BEFORE CHANGING SPEED TAPS OR ADDING DUCTWORK.

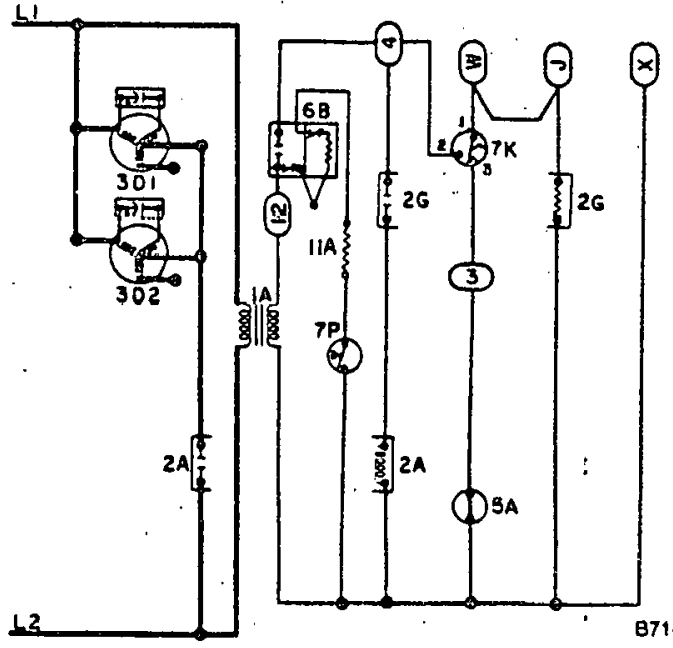

1A-TRANSFORMER 2A-BLOWER RELAY 2G-HEAT-MOTOR-OPERATED RELAY 3D1\&2-BLOWER MOTOR 5A.HEAT MOTOR VALVE 68-733 PILOT (REIGNITION) 7K-TEMPERATURE LIMIT. CONTROL 7P.PRESSURE SWITCH SPST I1A-RESISTOR

Figure 6 - With 733 Pllot Installed Automatic Electric Reignition (D1) 


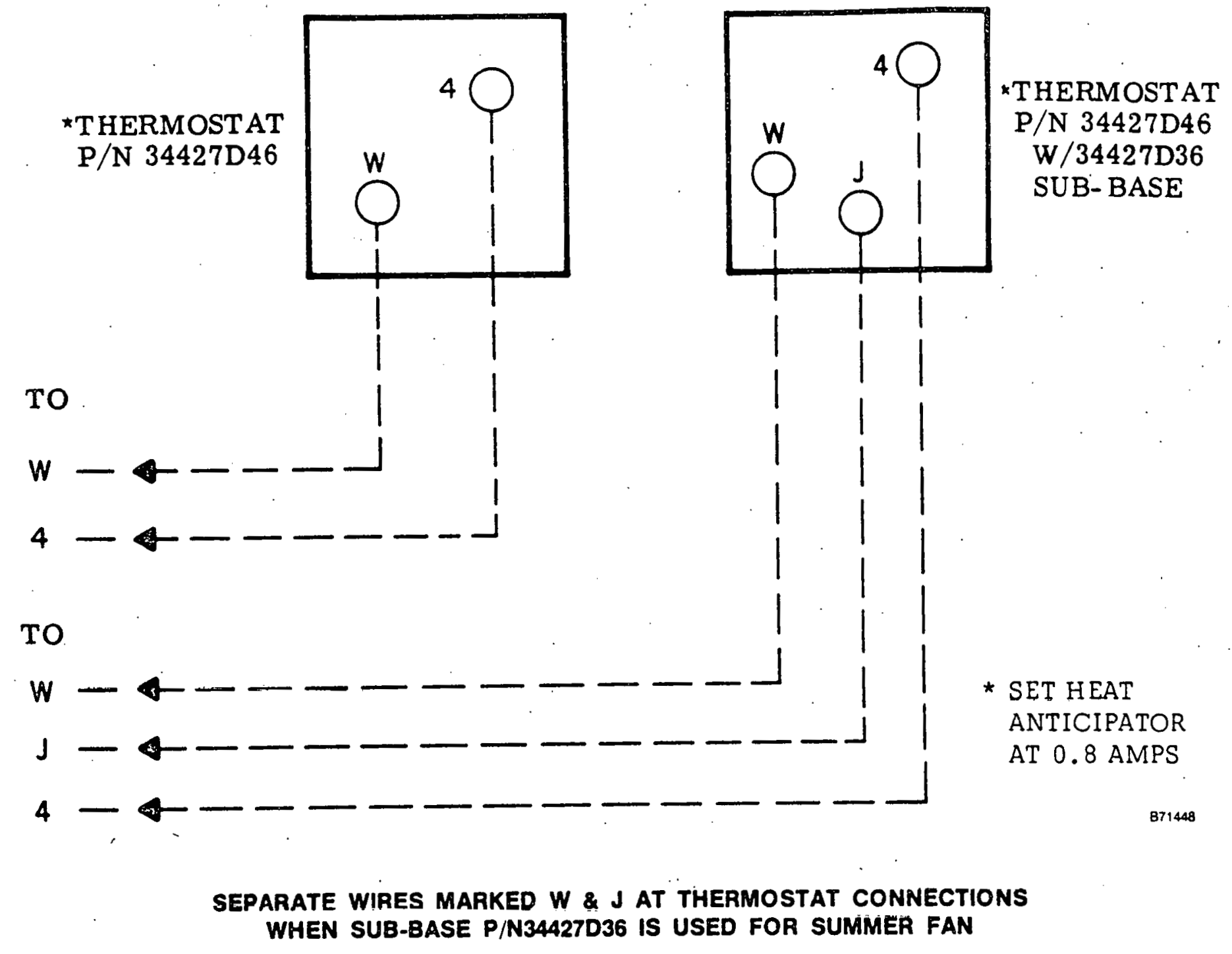

Figure 7 - Thermostat Field Wiring

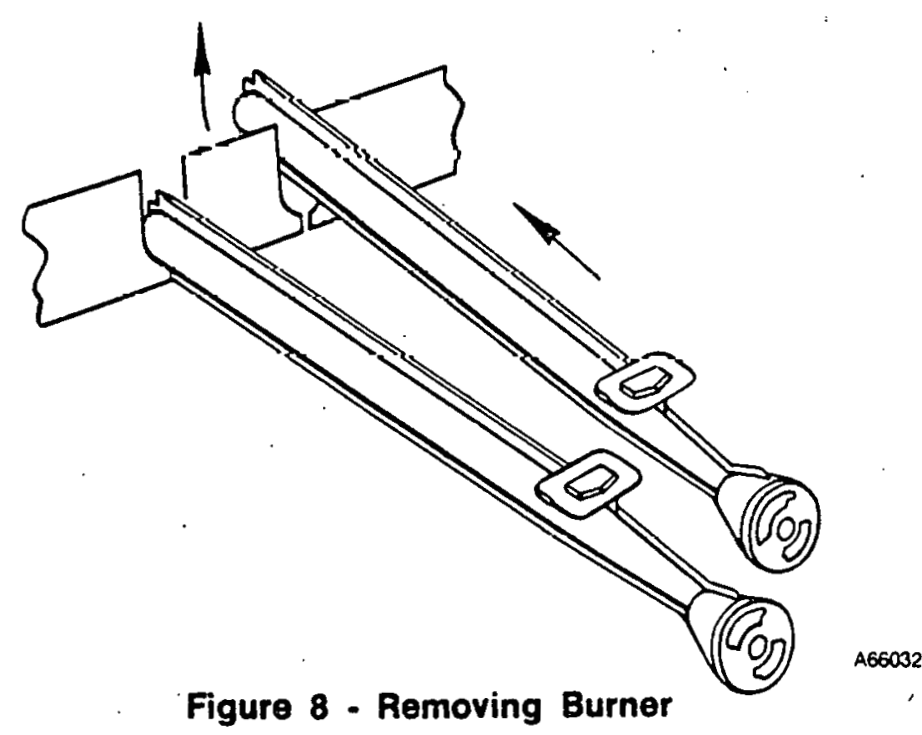

$\sqrt{J-66}$ 
Because the information originally included on pages $\mathrm{J}-67$ and J-68 was marked :Rights Reserved," these pages are deleted from this report. For information on Dover Corporation/Peerless Division, contact Peerless Division, P. O. Box 2015; Louisville, KY, 40201. 